Krzysztof Brzechczyn

\title{
The Historical \\ Distinctiveness \\ of Central Europe
}

A Study in the Philosophy of History

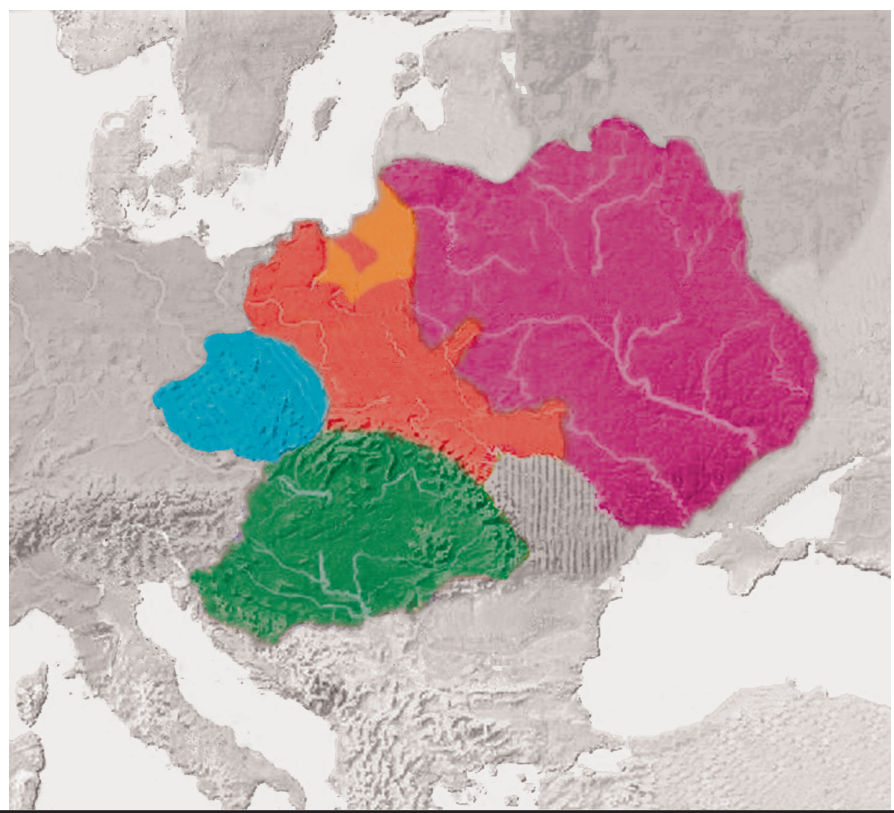

PETER LANG 


\section{Krzysztof Brzechczyn}

\section{The Historical Distinctiveness of Central Europe}

The aim of this book is to explain economic dualism in the history of modern Europe. The emergence of the manorial-serf economy in the Bohemia, Poland, and Hungary in the $16^{\text {th }}$ and the $17^{\text {th }}$ centuries was the result of a cumulative impact of various circumstantial factors. The weakness of cities in Central Europe disturbed the social balance - so characteristic for Western-European societies - between burghers and the nobility. The political dominance of the nobility hampered the development of cities and limited the influence of burghers, paving the way to the rise of serfdom and manorial farms. These processes were accompanied by increased demand for agricultural products in Western Europe

\section{The Author}

Krzysztof Brzechczyn is a professor at the Faculty of Philosophy in Adam Mickiewicz University in Poznań. He has authored several books and papers in different languages. His fields of interest include modern history, intellectual history, philosophy of history, social philosophy, and theory of historiography. 
The Historical Distinctiveness of Central Europe 


\title{
GESCHICHTE - ERINNERUNG - POLITIK STUDIES IN HISTORY, MEMORY AND POLITICS
}

Herausgegeben von / Edited by Anna Wolff-Powęska \& Piotr Forecki

\author{
Bd./Vol. 31
}

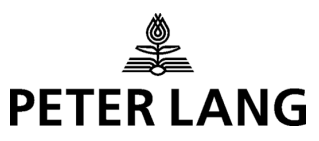




\section{Krzysztof Brzechczyn}

\section{The Historical Distinctiveness of Central Europe}

A Study in the Philosophy of History

Translated by Klara Naszkowska

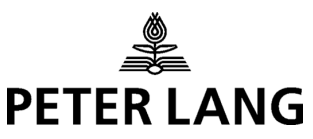




\title{
Bibliographic Information published by the Deutsche Nationalbibliothek
}

The Deutsche Nationalbibliothek lists this publication in the Deutsche Nationalbibliografie; detailed bibliographic data is available in the internet at http://dnb.d-nb.de.

\section{Library of Congress Cataloging-in-Publication Data}

A CIP catalog record for this book has been applied for at the Library of Congress.

The Publication is funded by Ministry of Science and Higher Education of the Republic of Poland as part of the National Programme for the Development of the Humanities (years 2017-2019, grant project no. 21H 160077 84)

\section{U NATIONAL PROGRAMME I FOR THE DEVELOPMENT OF HUMANITIES}

\author{
ISSN 2191-3528 \\ ISBN 978-3-631-80990-7 (Print) \\ E-ISBN 978-3-631-81371-3 (E-PDF) \\ E-ISBN 978-3-631-81372-0 (EPUB) \\ E-ISBN 978-3-631-81373-7 (MOBI) \\ DOI $10.3726 / \mathrm{b} 17029$
}
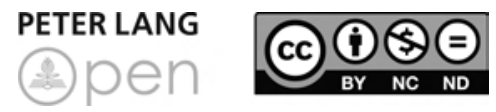

Open Access: This work is licensed under a Creative Commons Attribution Non Commercial No Derivatives 4.0 unported license. To view a copy of this license, visit https://creativecommons.org/licenses/by-nc-nd/4.0/

(c) Krzysztof Brzechczyn, 2020

Peter Lang-Berlin · Bern · Bruxelles · New York · Oxford · Warszawa · Wien

This publication has been peer reviewed.

www.peterlang.com 


\section{Preface}

Is it justified to employ the notion of "Central Europe"? Some argue that it is unreasonable and even harmful. Employment of this notion might have been acceptable during communist times, when it was supposed to emphasize the fact that nations located in this part of Europe, dependent on the Soviet Union, and simply identified with the East, have a distinct identity. However, nowadays each country from our region enjoys a status of a full member of the European Union, and each aspires to be recognized as a society of an entirely western type. In this context, an emphasis on regional distinctiveness can be understood as politically incorrect, as it suggests that Central-European societies have not risen yet to the Western standards and have to be labelled with a notion-prosthesis, such as "Central," understood as "not entirely Western" Europe.

Furthermore, the notion of "Central Europe" is very blurry: it is unclear which countries currently belong to Central Europe. For instance, let us ponder on the following question: does Estonia belong to Central Europe? A geopolitical intuition suggests that it did not before 1991. As a Soviet Republic, Estonia certainly belonged to Eastern Europe. However, the scope and speed of economic reforms introduced in Estonia after gaining independence forces us to exclude this country from the Eastern-European type of society and rather include it despite its northern geographical location - in Central Europe.

The above-mentioned blurriness of the notions of "Western Europe," "Central Europe," and "Eastern Europe" stems from the fact that distinct social structures and systems are identified with geographical terms. As a result, it is sometimes unclear whether the notion of Central Europe is employed in a purely geographic sense, or in a historical or social sense. Australia is situated to the South-East of Europe; however, Australian society is identified with a Western socio-political system. Thus, in this case geographical location is not essential. The affiliation of Australia with the West is determined by a set of features, which represent a social system that has emerged and evolved in a particular geographic area, and which took its name from this area.

Following from this, the notion of a Central-European society is synonymous with a social system, in which - let us state upfront - Western and Eastern features interweave. Hence, what shall we do with the case of Estonia? It appears that a twofold answer is possible:

- if a social system, which arose in the Estonian society, is consistent with an assumed model of a Central-European society, then the country belongs to 
Central Europe. To evade the risk of offending geographic intuitions, one commonly adds the adjective "Eastern;"

- if a social system, which arose in the Estonian society, does not have the features of a system allowing to include the country in the Central-European society (nor in the Western society), then, despite my enormous sympathy for the Estonians, the country belongs to Eastern Europe.

The purport of this book is to put forward arguments in favor of the thesis that Central-European societies have a different social structure than their Western-European counterparts and that the former have evolved in accordance with different rules and regularities. In this respect, distinctive features began to gradually appear in the Central-European path of development at the turn of the 15th century. The river Elbe became the borderline between the two developmental zones. West of the river, towns, craft production, and manufacture continued to expand, while peasants gained personal freedom. The social balance between burghers and the nobility enabled the state to gain in power and transform in the modern period from a state monarchy into an absolutist monarchy. By contrast, east of the river Elbe, towns in all countries of the region went through a considerable crisis - a decrease of population and craft production. In rural craftsmanship, the rise of a manorial-serf economy superseded the earlier monetary economy. The process was accompanied by growth in obligations imposed by the lords over the peasantry, and by the introduction of the so-called second serfdom. Additionally, the economic domination of the nobility was strengthened in political life - in all CentralEuropean societies, burghers exerted an insubstantial impact on public life as compared to Western Europe, whereas the state was subordinated to the interests of the nobility. The rise and evolution of the manorial-serf economy, which allowed for an increase of exploitation of the peasantry, was the basic factor bringing about a differentiation between two fundamental economic zones in modern Europe.

In this book - located in the field of the theory of the historical process or theoretical history - I put forward an explanation of the above-mentioned developmental differentiation. The book is divided into four parts. The first part ("On the Nature of Developmental Differentiation of Central Europe") outlines the key problems of the work. The first chapter ("In Defense of the Theory of the Historical Process") opens with a critical analysis of the accusations formulated by Isaiah Berlin, Karl R. Popper, Jean-François Lyotard, and Aviezer Tucker against the possibility of practicing theoretical history or a substantial philosophy of history. 
The second chapter ("The Concept of Central Europe") deals with key topics, which appeared in the debate concerning the division of the European continent in historiography, the borders of Central Europe, and the sources of its distinctiveness. The third chapter "On the Distinctiveness of Central Europe" - which provides a direct transition to the pivotal issue of the book - presents existing concepts explaining the Central-European developmental differentiation put forward by Jeremy Blum, Robert Brenner, Daniel Chirot, Marian Małowist, Władysław Rusiński, Jan Rutkowski, Jerzy Topolski, Immanuel Wallerstein, and Benedykt Zientara.

The second part of the book ("Methodological Assumptions") analyzes the phenomenon of historical distinctiveness of Central Europe against a methodological plane. My intension is to enrich the idealizational theory of science with the so-called concept of cascade processes, which allows us to capture the peculiarities of history within the idealizational approach to science in an improved way. A domineering opinion is that the model of the natural sciences, which employs the method of idealization, does not apply to the humanities. One may find a number of arguments supporting this claim in light of the idealizational theory of science. The above concept makes it possible to distinguish between two types of phenomena: essential structures dominated by the principal factor and essential structures dominated by the class of secondary factors. In the first type of phenomena, the power of influence exerted by the principal factor is greater than the joint powers of influence of secondary factors. In contrast, in the second type of the essential structures, the joint powers of influence of secondary factors is greater than the power of influence exerted by the principal factor, although the power of influence of the latter is greater than the power of influence of each secondary factor treated separately. Essential structures dominated by the principal factor are characteristic for the natural sciences, and essential structures dominated by secondary factors - for the social sciences. The phenomenon of a process of a cascade may occur in the latter type of essential structures. It is a gradual accumulation of various secondary factors up to the point when their joint influence becomes greater than the influence of the principal factor.

The fourth chapter in Part II titled "The Method of Idealization in the Historical Sciences" sheds light on the key ideas of the method of idealization and its application to the historical sciences. The chapter offers an idealizational reconstruction of the following theories: the theory of the genesis of second serfdom put forward by Evsey D. Domar, the theory of feudal system in Poland presented by Witold Kula, the model of the economy of Greater Poland put forward by Jerzy Topolski and the model of intercontinental trade developed by Frédéric Mauro. 
The fifth chapter ("The Methodological Characterization of the Cascade Effect") of the book uses the conceptual apparatus of the idealizational theory of science to characterize the cascade process and analyses its consequences for the idealizational structure of the scientific theory and historical narrative.

Part III ("Theoretical Assumptions") of the book applies the conceptualized process of a cascade to historical development. To that end, it is necessary to adopt a particular approach to the historical process. In the present book I adopted the theory of historical development formulated in non-Marxian historical materialism (hereinafter referred to as $\mathrm{n}-\mathrm{Mhm}$ ). Two subsequent chapters of Part III lay out the fundamental assumptions of the theory. The sixth chapter "The Basic Ideas of Non-Marxian Historical Materialism" outlines the basic theses of the theory of political development. It presents a division into class and supraclass societies in n-Mhm. A society of the State of Teutonic Knights represents the latter type of a social structure. This chapter puts forth reflections on the mono-linear and multi-linear approach to historical development, in light of the presented concept, using the example of the emergence of socialism in Russia.

The seventh chapter of this part entitled "Ownership and Revolution in nonMarxian Historical Materialism" discusses fundamental models of economic development: the basic model of an economic society and the model of a feudal society. The chapter provides a critical analysis of the status of the so-called Christian model of man. Additionally, it puts forward a distinction between two types of economic revolutions, based on anthropological assumptions of a non-Christian model of man. Moreover, adding the above distinction modifies the model of development of an economic society.

It appears that the cascade processes brought about one of the greatest paradoxes in the modern history of Europe, namely economic dualism. From the 13th to the 15th century, Western-European and Central-European societies evolved in accordance with analogical developmental regularities: traditional forms of natural economy were being replaced with rent economy, towns expanded, and local and international trade developed. However, since the turn of the 15th and 16th centuries, in a number of Central-European countries, and particularly in Poland, Bohemia, and Hungary, a manorial-serf economy arose. The evolution of a manorial-serf economy brought about a collapse of the urban realm of economy, caused serfdom to be introduced in the rural areas, and trade exchange with the West to gain a unilateral character - Central Europe has specialized in exporting agricultural products and raw materials, and in importing highly-process craft products. The differentiation of the developmental paths of Western Europe and Central Europe was a result of the impact of cascade processes, namely a gradual accumulation of various factors - secondary, from the 
viewpoint of $\mathrm{n}-\mathrm{Mhm}$, including: the shortage of manpower, underdevelopment of towns, demand for grain in Western Europe, etc., which exerted a greater joint influence than the influence of factors perceived as principal.

The fourth part of the book "The Conceptualization of the Distinctiveness of Central Europe" deals with the above-mentioned issue. In the eighth chapter entitled "Models of the Source of a Cascade," I build a theoretical model of an economic society with a shortage of manpower. In accordance with the concept under study, the shortage of workforce is the factor, which initiated a cascade of secondary factors, which, in turn, outweighed the impact of the principal factor. For comparative purposes, I also build a model of an economic society with a surplus of manpower. In the ninth chapter ("The Genesis of European Differentiation"), I draw on historical literature to reconstruct subsequent links of a cascade of factors responsible for developmental divergence of European societies. From the factors appearing in the cascade, I identify its core as consisting of factors, which operated in each of the societies under study, and factors characteristic for particular societies. The analysis presented in this part of the book combines theoretical and empirical approaches. I investigate a number of the above factors, namely the social consequences of both the deficiency and the surplus of workforce, by building models of socio-economic development in $\mathrm{n}$-Mhm. In my reconstruction of the influence of the remaining factors of the cascade of European differentiation I draw on the prolific historiographic literature devoted to the history of Central Europe.

The present book is a considerably modified and expanded edition of my doctoral thesis authored in the years 1990-1995 at the Department of Philosophy of the Adam Mickiewicz University in Poznan (AMU) under the supervision of Professor Leszek Nowak (1943-2009). Professor Nowak referred to extensive fragments of the thesis in his seminars held at the Chair of Epistemology at the Department of Philosophy at AMU, professor Jerzy Topolski (1928-1998) in his seminars held by at the Chair of Methodology and Modern History at the Department of History at AMU, professor Janusz Goćkowski (1935-2010) in his seminars held at the Chair of Philosophy and Sociology of Science, and professor Teresa Grabińska in her seminars held at the Chair of Methodology of Science, at the Department of Social and Economic Sciences at Wrockaw University of Technology. I would like to take this opportunity to express my gratitude to the participants of the above-mentioned seminars for expressing interest in the results of my work and for their friendly criticism. I would also like to thank professor Jerzy Topolski for his substantive and bibliographical guidelines supplied throughout my work on this volume. The book has also greatly benefited from the review provided by professor Jan Pomorski. 
The "Bibliography" provides a translation of the Polish titles of articles, chapters, and books into English. I used fragments of my articles previously published in English, adequately expanded and modified for the purpose of the book:

"The State of Teutonic Order as a Socialist Society," in: Social System, Rationality and Revolution. Poznań Studies in the Philosophy of the Sciences and the Humanities, Vol. 33, eds. Leszek Nowak and Marcin Paprzycki (Amsterdam/Atlanta, GA: Rodopi, 1993), pp. 397-417.

"In Defence of Metanarrative in the Philosophy of History," Interstitio. East European Review of Historical Anthropology, Vol. 2, No. 1(3) (2008), pp. 7-22.

"Methodological Peculiarities of History in the light of Idealizational Theory of Science," in: Idealization XIII: Modeling in History. Poznan Studies in the Philosophy of the Sciences and the Humanities, Vol. 97, ed. Krzysztof Brzechczyn (Amsterdam/New York: Rodopi, 2009), pp. 137-157.

"The Distinctiveness of Central Europe in light of the Cascadeness of the Historical Process," in: Idealization XIII: Modeling in History. Poznań Studies in the Philosophy of the Sciences and the Humanities, Vol. 97, ed. Krzysztof Brzechczyn (Amsterdam/ New York: Rodopi, 2009), pp. 231-269.

"Strategies of Comparative Analysis in Historical Comparative Sociology: An Attempt at an Explication within the Conceptual Framework of the Idealizational Theory of Science," in: Idealization XIV: Models in Science. Poznan Studies in the Philosophy of the Sciences and the Humanities, Vol. 108, eds. Krzysztof Brzechczyn and Giacomo Borbone (Boston/Leiden: Brill/Rodopi, 2016), pp. 184-201. 


\section{Contents}

Preface

\section{Part I On the Nature of the Developmental Differentiation of Central Europe}

1 In Defense of the Theory of the Historical Process ...................... 19

1 Introduction .................................................................................... 19

2 On the Schematization of the Theory of the Historical Process ........... 20

3 On the Prognoses in the Theory of the Historical Process .................... 27

4 On the Loss of Nostalgia for the Metanarrative ...................................... 30

5 On the Teleology of Substantial Philosophy of History .......................... 33

6 On the Need for the Theory of the Historical Process ............................ 36

2 The Concept of Central Europe ............................................................... 41

1 Introduction …………………....................................................... 41

2 On the Criteria of Distinguishing Central Europe ................................ 42

3 On the Borders of Central Europe ............................................................. 52

4 On the Nature of the Distinctiveness of Central Europe ....................... 54

3 On the Distinctiveness of Central Europe ..................................... 57

1 Theories Referring to External Factors .................................................... 57

1.1 The Concept of Marian Małowist ..................................................... 57

1.2 The Concept of Immanuel Wallerstein ................................................ 60

2 Theories Referring to Internal Factors .................................................. 65

2.1 The Concept of Robert Brenner .......................................................... 65 
2.2 The Concept of Jerzy Topolski .......................................................... 69

2.3 The Concept of Benedykt Zientara .................................................. 74

3 Combined Theories …………………………..................................... 75

3.1 The Concept of Daniel Chirot ......................................................... 75

3.2 The Concept of Władysław Rusiński .............................................. 77

3.3 The Concept of Jeremy Blum …………………………………….. 79

3.4 The Concept of Jan Rutkowski ......................................................... 82

4 A Recapitulation ............................................................................ 84

\section{Part II Methodological Assumptions}

4 The Method of Idealization in the Historical Sciences ............. 91

1 Idealization in the Social Sciences: Case Studies .................................... 91

2 The Method of Idealization ..................................................................... 94

3 The Idealizational Law and its Concretization ..................................... 99

4 Operationalization of the Idealizational Theory .................................... 102

5 On Some Extensions of the Idealizational Theory of Science ............. 103

5.1 On Different Kinds of Counter-factual Assumptions ................... 103

5.2 On the Specification of Idealizational Statements ......................... 105

6 The Comparative Method and Idealization ............................................ 107

7 The Method of Modeling in the Economic History .............................. 114

7.1 Classification of Economic Models ................................................ 114

7.2 Evsey Domar's Theory of the Rise of Exacerbated Serfdom ........ 117

7.3 Witold Kula's Theory of the Feudal System in Poland ................... 120

7.4 Jerzy Topolski's Model of Economy of Greater Poland ................ 128

7.5 Frédéric Mauro's Theory of Intercontinental Trade ....................... 131

7.6 A Recapitulation ............................................................................ 135

8 The Limitations of the Method of Idealization .................................... 136

5 The Methodological Characterization of the Cascade Effect ...... 147

1 Two Types of Essential Structures …………………………………...... 147 
2 On Small Causes and Huge Effects ........................................................ 150

3 The Interaction of Factors in the Cascade .............................................. 154

4 The Cascade Effect and the Scientific Theory ........................................ 156

5 The Cascade Effect and the Historical Narrative ................................... 157

6 The Cascade Effect in Light of Categorial Ontology ............................. 159

$7 \quad$ The Rationale of Idiographism in the History ........................................ 162

8 The Cascade Effect and Economic Dualism in Modern Europe ........ 166

\section{Part III Theoretical Assumptions}

6 The Basic Ideas of Non-Marxian Historical Materialism ........ 171

1 Presentation of Basic Ideas ................................................................. 171

$1.1 \quad$ A Typology of Societies ................................................................... 171

1.2 A Model of Evolution of a Purely Political Society ........................ 175

1.3 The Global Model of a Political Society ........................................... 181

2 On the Class Divisions in the State of Teutonic Knights ..................... 184

2.1 Problem .................................................................................. 184

2.2 The Social Structure of the Teutonic State ..................................... 185

2.3 Evolution of a Teutonic Society ........................................................ 190

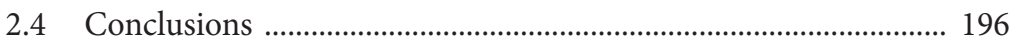

3 Alternative History and the Rise of Socialism in Russia ..................... 197

\section{Ownership and Revolution in Non-Marxian Historical}

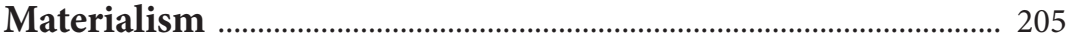

1 On Some Basic Mechanisms of Social Development ............................ 205

1.1 Adaptive Mechanisms ...................................................................... 205

1.2 The Mechanism of a Class Struggle .............................................. 208

2 On Two Models of Economic Society ………………………………..... 209 
2.1 The Basic Model of Purely Economic Society ................................ 209

2.2 An Economic Model of Feudal Society ............................................ 214

3 On Two Types of an Economic Revolutions ......................................... 219

3.1 Non-rationalistic Model of a Man .................................................. 219

3.2 Critique of the Reconstruction of a Christian Model of Man ..... 223

3.3 A Non-rationalistic Model of Man in the Area of Economy ....... 225

3.4 Two Types of Revolutions in the Model of an Economic Society 231

\section{Part IV The Conceptualization of the Distinctiveness of Central Europe}

8 Models of the Source of a Cascade ................................................. 239

1 Model II: An Economic Society with a Surplus of Manpower ........... 239

1.1 Assumptions of the Model ................................................................ 239

1.2 Social Resistance of the Unemployed ............................................... 239

1.3 Social Resistance of the Employed .................................................... 241

1.4 The Image of Social Resistance of Direct Producers ..................... 242

1.5 Development of an Economic Society with a Surplus of Manpower ....................................................................................... 245

2 Model III: An Economic Society with a Shortage of Manpower ........ 248

2.1 Assumptions of the Model ................................................................ 248

2.2 The Shortage of Manpower versus the Social Resistance ............. 249

2.3 Development of an Economic Society with a Shortage of Manpower ........................................................................................... 252

2.4 A Scope of the Historical Application of Models .......................... 255

9 The Genesis of European Differentiation ...................................... 259

1. On the Peculiarities of Feudalism in Central Europe ........................... 259

2. The Emergence of a Cascade of European Differentiation ................... 267

2.1 The Core of the Cascade of European Differentiation ................... 267

2.2 The Polish Variant .......................................................................... 287 
2.3 The Hungarian Variant .............................................................. 300

2.4 The Bohemian Variant ................................................................. 307

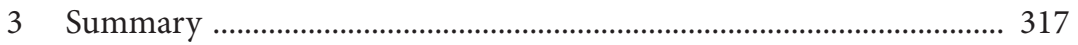

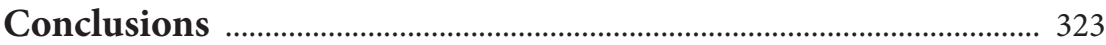

\section{Appendices}

\section{Civilizational Dimensions of Non-Marxian Historical}

Materialism

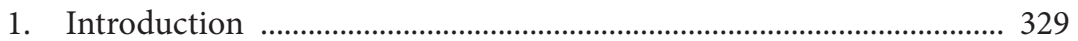

2. Civilizational Aspects of Non-Marxian Historical Materialism ....... 330

3. Social Practice versus Types of Class Stratification ............................ 332

4. Between Ecological Conditions and Socio-economic Practice .......... 337

An Individual and Two Approaches toward Political Revolution

List of Figures

List of Tables

Bibliography

Name Index 



\section{Part I On the Nature of the Developmental Differentiation of Central Europe}





\section{In Defense of the Theory of the Historical Process}

\section{Introduction}

From its very birth in the ancient Greece, philosophical thought has included a reflection over human society and its past. However, philosophy of history, as a separate philosophical discipline conscious of its object of study and methods, emerged in the Age of Enlightenment. Giambattista Vico, the Italian intellectual who lived at the turn of the 17th and 18th centuries, was named the pioneer of the discipline. He termed it the "new science." Philosophical reflection over history was "new" in the sense that, in the Age of Reason, it escaped from the influence of religion and theology. Voltaire introduced the term "philosophy of history" in 1765. ${ }^{1}$ In the course of its evolution, the discipline has been understood as:

- an interpretation of the past or of a fraction of the past using philosophical categories and concepts, or an explication of the past provided with reference to laws/models/theories responsible for social development;

- a description of the past perceived from the perspective of universal history of human kind;

- an evaluation and a search for meaning in history, or in separate historical events;

- a theory of knowledge and historical cognition.

The Anglo-Saxon world offers an additional distinction into two branches of analytic (or critical) and speculative (or substantial) philosophy of history. ${ }^{2}$

1 Zbigniew Kuderowicz, Filozofia dziejów (Warszawa: Wiedza Powszechna, 1983), pp. 5-7.

2 See for example: Ronald Field Atkinson Knowledge and Explanation in History. An Introduction to the Philosophy of History (Ithaca: Cornell University Press, 1978), pp. 8-10; Arthur Danto, Analytical Philosophy of History (Cambridge: Cambridge University Press, 1965), William Henry Walsh, An Introduction to Philosophy of History (New York: The Harvester Press, 1976), pp. 9-24; in Polish literature, the above distinction corresponds with a division into an ontological and an epistemological dimension of the philosophy of history, see: Andrzej F. Grabski, Ksztatty historii (Łódź: Wydawnictwo Łódzkie, 1985), pp. 47-48; Dawid Rogacz, Chińska filozofia historii. Od początków do końca XVIII wieku (Poznań: Wyd. Naukowe UAM 2019), pp. 24-31. 
Analytic philosophy of history belongs to philosophy of science, and it deals with the following issues concerning historical knowledge: modes of explanations, nature of a historical fact, structure of a historical narrative, status of historical laws. Substantial philosophy of history puts forward statements concerning the course of the historical process. Out of the above list, substantial philosophy of history has the first three features and analytic philosophy of history has the last feature. The substantial philosophy of history may predominantly emphasise the explanatory aspect of a given dimension of the past under study. Then it can be alternatively described as "theory of the historical process," or "theoretical history." When a given concept from substantial philosophy of history includes also the axiological aspect of the past, it is termed historiosophy. ${ }^{3}$

Regardless of the understanding of the substantial philosophy of history minimalistic or maximalist - this type of humanistic reflection has raised a lot of controversy: from Karl R. Popper's criticism of the impossibility to formulate laws governing historical development to Jean-François Lyotard's claims about a totalitarian virus present in the very intention of constructing metanarratives. The present chapter offers a critical analysis of the accusations formulated by Isaiah Berlin, Karl R. Popper, Jean-François Lyotard, and Aviezer Tucker against the substantial philosophy of history.

\section{On the Schematization of the Theory of the Historical Process}

According to Isaiah Berlin, the characteristic feature of conceptions formulated within the substantial philosophy of history is their recognition of the past reality as a homogenous and universal developmental model. Berlin, such an understanding of history assumes that

[t]here is some single explanation of the order and attributes of persons, things, and events. Usually this consists in the advocacy of some fundamental category or principle

3 For instance, according to Zbigniew Kuderowicz (Kuderowicz, Filozofia dziejów, p. 5) and Karl Löwith, search for meaning in the past is a substantial feature of the philosophy of history. Löwith claims that, "the term 'philosophy of history' is used to mean a systematic interpretation of universal history in accordance with a principle by which historical events and successions are unified and directed toward an ultimate meaning;" see: Karl Löwith, Meaning in History (Chicago/London: University of Chicago Press, 1949), p. 1. On various conceptions of the meaning of history, see also: Tadeusz Buksiński, "Czy historia ma sens?," in: Zaproszenie do filozofii, eds. Krzysztof Łastowski and Paweł Zeidler (Poznań: Humaniora, 2001), pp. 99-115. 
which claims to act as an infallible guide both to the past and to the future, a magic lens revealing "inner," inexorable, all-pervasive historical laws, invisible to the naked eye of the mere recorder of events, but capable, when understood, of giving the historian a unique sense of certainty - certainty not only of what in fact occurred, but of the reason why it could not have occurred otherwise. ${ }^{4}$

Substantial philosophy of history understood as above bears two characteristic features: it generates one universal model of history concerning a certain distinguished social entirety, such as Humanity, in which separate historical facts are perceived as necessary components of an order of events. According to Berlin,

$[\mathrm{t}$ ]o understand is to perceive patterns. To offer historical explanations is not merely to describe a succession of events, but to make it intelligible; to make intelligible is to reveal the basic pattern - not one of several possible patterns, but the one unique plan which, by being as it is, fulfils only one particular purpose, and consequently is revealed as fitting in a specifiable fashion within the single "cosmic" overall schema which is the goal of the universe, the goal in virtue of which alone it is a universe at all, and not a chaos of unrelated bits and pieces [...]. Unless an event, or the character of an individual, or the activity of this or that institution or group or historical personage, is explained as a necessary consequence of its place in the pattern (and the larger, that is, the more comprehensive the schema, the more likely it is to be the true one), no explanation - and therefore no historical account - is being provided. The more inevitable an event or an action or a character can be exhibited as being, the better it has been understood, the profounder the researcher's insight, the nearer we are to the one embracing, ultimate truth. $^{5}$

For Berlin, this kind of approach to history was a manifestation of a "metaphysical fantasy." His argument can be reconstructed in the following way: historical reality is typically multi-formed and multi-streamed. It is significantly more complex in reality than according to a philosopher of history, who is armed with "categories and rules," hence it cannot be forced to fit into a Procrustean bed of any philosophy of history. ${ }^{7}$

4 Isaiah Berlin, "Political Ideas in the Twentieth Century," in: Berlin, Liberty, ed. Henry Hardy (Oxford: Oxford University Press, [1949] 2002), p. 55.

5 Isaiah Berlin, "Historical Inevitability," in: Berlin, Liberty, ed. Henry Hardy (Oxford: Oxford University Press, [1954] 2002), pp. 104-105.

6 Berlin, "Historical Inevitability," p. 56.

7 Moreover, Berlin formulated an accusation of immoralism of the substantial philosophy of history. For a polemic with this charge, see: Leszek Nowak, Władza. Próba teorii idealizacyjnej (Warszawa: In Plus, 1988), pp. 160-163. 
A closer look at conceptions belonging to the substantial philosophy of history reveals that they can be divided into three types, according to the criterion of the degree of universality of the formulated statements:

(i) universalistic;

(ii) dualistic;

(iii) pluralistic. $^{8}$

According to universalistic conceptions, theories/models/dependencies or developmental mechanisms formulated within them pertain to all societies equally. It needs to be admitted that the formulated dependencies are being frequently applied in a dogmatic manner in order to explicate a historical reality.

A good example of the approach to history described above is the Stalinist version of historical materialism popularized in the Soviet Union in the 1930s and in the socialist states of the Eastern Bloc in the years 1944-1956. Joseph Stalin put forward a binding interpretation of this form of Marxism in his work Dialectical and Historical Materialism published in 1938, where "the great leader of the proletariat" in a very authoritative manner outlined five-staged developmental model including primitive communal system, slavery, feudalism, capitalism, and socialism. The Marxist ideology proved detrimental to Marxism as such because, by legitimizing a totalitarian social system, it ceased to be a scientific theory developed by virtue of internal criticism and confrontation with empirical data.

However, the aforementioned universalism of the substantial philosophy of history is not characteristic solely for Marxism. It is also present in the social philosophy of liberalism, for example in Walt Whitman Rostow's theory of modernization. According to this conception, the principal social factor is the development of modern science. The evolution of modern science and the successful application of its achievements brought about a modernization of economy, which, in turn, resulted in a creation of a modern nation state. According to Rostow, the history of all human societies evolves through the following five stages of economic development: traditional society, pre-conditions to modernization take-off, modernization take-off, drive to maturity, and age of mass consumption.

8 For other classifications of the theory of historical process, see: Marek Wichrowski, Spór o naturę procesu historycznego. Od Hebrajczyków do śmierci Fryderyka Nietzschego (Warszawa: Semper, 1995), pp. 9-13; Kenneth Ghosh, "Some Theories of Universal History," Comparative Studies in Society and History, Vol. 7 (1964), pp. 1-20. 
In traditional societies, modern science was yet to be developed and environmental conditions restricted economic growth. Family ties and clan relations dominated the social aspect of public life, and the entire social life had a hierarchical character. In traditional societies, the system of values was permeated with fatalism, or a conviction that, in all generations, individual members of society will have the same scope of life chances. According to Rostow,

[i]n terms of history then, with the phrase "traditional society" we are grouping the whole pre-Newtonian world: the dynasties in China; the civilization of the Middle East and the Mediterranean; the world of medieval Europe. And to them we add the postNewtonian societies, which, for a time, remained untouched or unmoved by man's new capability for regularly manipulating his environment to his economic advantage. ${ }^{9}$

The second stage described by Rostow as "pre-conditions to modernization takeoff" is characterized by the application of the inventions of budding modern science, which brings about economic development. Simultaneously, agriculture was still the primary economic sector. In order to initiate a modernization takeoff a society had to satisfy three conditions: to produce enough food to feed the growing town population, to serve as an outlet for production of the means of production, and owners should invest profits from agriculture into industrial production. This stage is characterized by the beginnings of international market and creation of nation states what is condition for a modernization take-off.

This was followed by an accelerated industrialization and urbanization of society. At this stage, the level of investment increased to 5-10\% of net national income, and a rapid advancement of particular industrial branches took place resulting in the development of remaining economic fields and transformations of political and public life. Rostow argues that all societies experienced the following developmental stage in various moments in history:

one approximately allocate the take-off of Britain to the two decades after 1783; France and the United States to the several decades preceding 1860; Germany, the third quarter of the nineteenth century; Japan, the fourth quarter of the nineteenth century; Russia and Canada the quarter-century or so preceding 1914; while during the 1950's India and China have, in quite different ways, launched their respective take-offs. ${ }^{10}$

In the subsequent stage of historical development, which Rostow terms "the drive to maturity," achievements of the previous stage were consolidated. In this phase of development, around $10-20 \%$ of net national income was invested

9 Walt W. Rostow, The Stages of Economic Growth. A Non-Communist Manifesto (Cambridge: Cambridge University Press, 1964), p. 5.

10 Rostow, The Stages, p. 9. 
in economic growth. In the previous stage, mining and heavy industries were developed, while now the major investment was in the development of chemical, electrical, and machinery industries.

The final stage - the age of mass consumption - was reached when the primary income of the greater part of members of society had allowed for satisfaction of other demands, which go beyond basic needs, such as food, accommodation, and clothing. As society became predominantly urban, the majority of people was employed in the service sector. In the age of mass consumption, all members of society are capable of achieving prosperity - on account of welfare state institutions. At the time when Rostow formulated his claim, the United States (1946-1956), Western Europe and Japan (1950s) entered this stage of social advancement.

A contrast between European and Asian societies has become the foundation of dualistic theories. For instance, Karl August Wittfogel put forward a theory of hydraulic societies, which has revitalized the discussion on Asian social formation after the Second World War. ${ }^{11}$ According to Wittfogel, the tradition of distinguishing between occidental and oriental lines of development originates from the period when nomadic tribes proceeded from hunting and gathering to a sedentary life based on cultivation of land. The line of historical development was influenced by access or lack of access to water. In Europe, the abundance of water reservoirs ensured individual access to aquatic resources. However, the areas of Near East and Far East experienced shortages of water and rainfall. In order to survive, these societies were forced to organize irrigation works designed to tame large-scale rivers. The state was established to organize irrigation works and supervise the process of organization of production. Subsequently, it was no longer necessary to conduct regular irrigation works but the state organization founded for this purpose remained. In Asian societies, despotic-bureaucratic systems were established, hampering the development of private property and subjugating religious organizations.

With regard to the degree and scope of state interference into socio-economic life, Wittfogel distinguished between classic, marginal, and sub-marginal hydraulic societies. In classic hydraulic systems, state exercised direct control over irrigation works and organized them. Classic societies included: ancient

11 According to Jarosław Bratkiewicz, the tradition to distinguish between occidental and oriental development line was initiated by Herodotus in Antiquity, cf. Jarosław Bratkiewicz, Teoria przedkapitalistycznej formacji społecznej w kulturach orientalnych. Interpretacja badań i polemik (Wrocław: Ossolineum, 1989), pp. 3-12. 
Chinese, Egyptian, Indian, Inca, and Mesopotamian societies. In marginal hydraulic societies, the state dealt with building facilities and organization of ventures directly not associated with building canals, and additionally fulfilled a number of social functions, such as tax collection and defense. The Byzantine Empire is a good example of such society. Finally, in sub-marginal hydraulic systems developed in Russia and Turkey, state manifested its power in enforcing collection of taxes, developing defense systems against external aggression and maintaining legal order.

In his comparison of the historical development of Asian and European societies, Wittfogel claimed that Asian societies are characterized by state ownership of the means of production, despotism, dominance of the collective over the individual, and social stagnation. In contrast, characteristic features of European societies included: private ownership of the means of production, political freedom manifested in bottom-up formation of civil organizations, dominance of the individual over collective and dynamic development.

According to Wittfogel, capitalistic societies derive from the feudal system formed in the Western developmental line, while the system of real socialism in the Soviet Union and China derives from hydraulic systems formed in the oriental developmental line:

The agrarian despotism of the old society, which, at most, was semi-managerial, combines total political power which limited social and intellectual control. The industrial despotism of the fully developed and totally managerial apparatus society combines total political power with total social and intellectual control. ${ }^{12}$

Based on this, Wittfogel claims that the two developmental lines had been distinguished in the past and there were no new separate developmental lines distinguished afterwards. Moreover, hydraulic societies found their continuation in real socialism and feudalism - in democratic capitalism.

Pluralistic conceptions presume existence of many types of societies evolving according to distinct regularities. Samuel Huntington's theory, which employs the concept of civilization, is one of such conceptions:

A civilization is thus the highest cultural grouping of people and the broadest level of cultural identity people have short of that which distinguishes humans from other

12 Karl A. Wittfogel, Oriental Despotism. A Comparative Study of Total Power (Yale: University Press, 1972), p. 440. 
species. It is defined both by common objective elements, such as language, history, religion, customs, institutions and by the subjective self-identification of people. ${ }^{13}$

Nonetheless, nation states are the most influential entities on the international arena and, as emphasized by Huntington, their interests, making covenants, and conflicts are defined by cultural factors, which determine their civilizational identity. As cultural formations, civilizations do not have clearly defined political boundaries and their political structure is characterized by great diversity. As a result, civilizations may include a single country (i.e. Japanese civilization) or a number of sovereign countries (i.e. Western civilization). The latter type of civilizations may be centered on a recognizable leading state (i.e. Russia in the civilization of Eastern Orthodox Christianity) or there may be no leader (e.g. in the Latin-American civilization or in the Islamic civilization, a number of countries aspire to the role of a leader; however, as of now, none of them managed to gain dominance over others). Huntington differentiated seven currently existing civilizations and one emergent:

- Sinic or Chinese civilization - dating back to the 15th century BC; its cultural core is Confucianism; it encompasses China, Vietnam, and South Korea and Chinese communities living abroad;

- Japanese civilization - emerged from Chinese civilization between the 1st and the 4 th centuries;

- Hindu civilization - formed around in the 14th century BC; its cultural core is Hinduism;

- Islamic civilization - created in the 7th century on the Arabian Peninsula; currently spreading over North Africa, Near East, and Central Asian countries; it encompasses a number of cultures: Arabic, Turkish, Persian, and Malayan;

- Orthodox civilization - a continuation of the Byzantine civilization; differs from Western Christianity by two hundred years of Tatar rule, bureaucratic despotism and restrained contact with Western cultural tendencies: the Renaissance, Reformation, and Enlightenment;

- Western civilization - dating back to the 8th and the 9th centuries; its characteristic features include: heritage of classical antiquity, Catholicism and Protestantism, a multiplicity of European languages, separation of spiritual and secular power, the rule of law, social pluralism, development of representative institutions, and individualism;

13 Samuel Huntington, The Clash of Civilizations and the Remaking of World Order (New York: Penguin Books, 1997), p. 43. 
- Latin-American civilization - despite being a formation of European civilization, its developmental line differs from Western civilization in terms of culture, politics, and economy. Latin-American culture, authoritarian and corporate, is a synthesis of a dominant Catholic culture and native Indian cultures;

- African civilization (potential) - the north of the continent belongs to Islamic civilization; African civilization will come to existence if the societies living on the south part of the Sahara overcome antagonisms and tribal identities in favor of an African identity. ${ }^{14}$

Cultural identity of a civilization to a large extent influences developmental lines of societies forming particular civilizations. Huntington states that it is a key factor in the future development of relations between the West and other civilizations.

If we treat Berlin's criticisms as a criterion for a typology of the theory of the historical process, some of these conceptions will be subject to his charges (universalistic conceptions) and some will not. ${ }^{15}$ For this reason, Berlin's critique is partially legitimate.

\section{On the Prognoses in the Theory of the Historical Process}

Karl R. Popper questioned the usefulness of formulating laws of historical development and possibility of putting prognoses in the historical sciences. According to him, a historicist doctrine (in its naturalistic version) of the social sciences is modeled on the natural sciences. Since these sciences (astronomy) are capable of making predictions regarding natural phenomena with a high degree of precision and for a long time ahead, i.e. solar eclipse, so should the social sciences be capable of forecasting certain social phenomena, i.e. revolutions? Following from this, the social sciences have fundamentally the same tasks as the natural sciences - formulation of scientific prophecies capable of predicting the social and political evolution of the humankind. Based on such prophecies, it is possible to determine the tasks of politics, which, following Marx's definition, are

14 Huntington, The Clash of Civilizations, pp. 45-48.

15 It is noteworthy that in terms of non-Marxian historical materialism, the accusation of schematization is discussed in: Leszek Nowak, Katarzyna Paprzycka and Marcin Paprzycki, "On Multilinearity of Socialism," in: Social System, Rationality and Revolution, eds. Leszek Nowak and Marcin Paprzycki (Amsterdam: Rodopi, 1993), pp. 355-371. 
supposed to ease the "labor pains" preceding the predicable, inevitable political events. Popper argued that,

[a]dmittedly all theoretical sciences are predicting sciences. Admittedly there are social sciences, which are theoretical. But to these admissions imply - as the historicists believe - that the task of the social sciences is historical prophecy? It looks like it: but this impression disappears once we make a clear distinction between what I shall call "scientific prediction" on the one side and "unconditional historical prophecies" on the other. Historicism fails to make this important distinction. ${ }^{16}$

Scientific predictions usually have a conditional character. If certain changes occur, they will be accompanied by other phenomena (if the temperature of water in a kettle increases, the water starts to boil). The physicist will say that under certain conditions the kettle will explode, the economist will say that under certain conditions a black market will develop, etc. From such conditional scientific prognoses and historical statements ascertaining the fulfilment of possible conditions, it is sometimes possible to draw unconditional predictions under the modus ponens argument. If a doctor diagnoses scarlet fever, he/she then concludes that a patient will have a rash.

However, it is possible to formulate unconditional prophecies without theoretical justification, on which conditional scientific predictions are based - these predictions can come true by accident.

The historicist does not derive his/her prophecies from conditional scientific predictions, as this is impossible. In Popper's view, predictions can be formulated about isolated, stationary, and recurrent systems. Among such systems are: the Solar System, life cycles of biological organisms, or weather cycles. However, the method of long-term prediction cannot be applied to the history of humankind, since in the development of human societies there appear non-repetitive phenomena. And, according to Popper, prediction is conditional on repetitiveness as long as certain phenomena are repetitive, predictions can be made. This type of repetitiveness can be found in how new religions emerge or tyranny arises. Still, another of Propper's arguments is that historical development is mainly non-repetitive and thus unpredictable:

The course of human history is strongly influenced by the growth of human knowledge. [...]

16 Karl Raimund Popper, "Prediction and Prophesy in the Social Science," in: Popper, Conjectures and Refutations: the Growth of Scientific Knowlegde (New York: Harper \& Row, [1948] 1968), p. 339. 
1. We cannot predict, by rational or scientific method, the future growth of our scientific knowledge. [...]

2. We cannot, therefore, predict the future course of human history.

3. This means that we must reject the possibility of a theoretical history; that is to say, of a historical social science that would correspond to theoretical physics. There can be no scientific theory of historical development serving as a basis for historical prediction. ${ }^{17}$

What is left, then, for the social sciences? According to Popper, the principal task of the theoretical social sciences is "to trace unintended social repercussions of intentional human actions." ${ }^{18}$ Popper illustrates this by describing an intention to purchase a house in a certain neighbourhood. The intention of the buyer is certainly not to bring about an increase of prices of the houses in the chosen neighborhood. However, the very fact of there appearing a potential buyer on the market will lead to a boost in the prices of the houses. The aforementioned task brings the theoretical social sciences close to the experimental natural sciences. Both types of sciences formulate praxeological rules stating what can be achieved:

The second law of thermodynamics can be expressed as the technological warning, "You cannot build a machine which is 100 per cent efficient." A similar rule of the social sciences would be, "You cannot, without increasing productivity, raise the real income of the working population" [...] These examples may show the way in which the social sciences are practically important. They do not allow us to make historical prophecies, but they may give us an idea of what can, and what cannot, be done in the political field. ${ }^{19}$

In the presentation of Popper's views on the role of the social sciences, it is important to distinguish a negative aspect, or what the social sciences should not be doing, and a positive aspect, or what the social sciences should be doing. Let us begin with the negative aspect. In his analysis of Popper's argumentation, Leszek Nowak states that the assumption (i) of the argument is the most typical statement concerning the historical process. ${ }^{20}$ As Nowak argues, "[i]f one attempts to

17 Karl Raimund Popper, The Poverty of Historicism (New York: Harper \& Row, [1944/45] 1964), pp. vi-vii.

18 Popper, "Prediction and Prophesy," p. 342.

19 Popper, "Prediction and Prophesy," p. 343.

20 Leszek Nowak, Power and Civil Society. Towards a Dynamic Theory of Real Socialism (New York: Greenwood Press, 1991), pp. 217-221. For a comprehensive critical presentation of Popper's views on the problem o possibility of conducting theoretical history, see: Nikolai S. Rozov, "An Apologia for Theoretical History," History and Theory, Vol. 37 (1997), pp. 336-352. 
prove incorrectness of a certain domain of thought, in an argument purported for this he/she cannot use claims belonging to the very domain in question." ${ }^{21}$ According to Nowak, Popper makes the same mistake that the representatives of the Vienna Circle were charged with, namely, to prove logical impossibility of metaphysics on the basis of a particular claim belonging to a certain type of metaphysics - materialist metaphysics of physicalism. In this case, Popper, as Nowak claims, demonstrates the impossibility of the theory of history on the basis of an idealist theory of history, which may or may not be accepted. ${ }^{22}$ Whereas assumption (ii) is true - to predict a future discovery means to know it in advance, but it is not this assumption which is in fact absent from Popper's argument, but its enthymeme that is employed in Popper's argument: "To predict the future course of history it is indispensible to know the content of future scientific knowledge." ${ }^{23}$ In Nowak's opinion, however, this assumption is false, since the shape of the influence of future scientific theories on many significant social phenomena can be determined entirely independently of their content: we do not know anything about the state of future paediatrics and about the findings made in this domain in the future, but we do not have to know this to predict a number of quantities. It will suffice that, by extrapolating the type of dependencies present to-date, we will predict further drop of mortality of infants. It should be noted at this point that assumption (ii2) also tacitly contains the prognosis about the continuous growth of human knowledge. One might ask, on what ground, if, as stated by Popper, forecasting in the social sciences is impossible.

\section{On the Loss of Nostalgia for the Metanarrative}

The postmodern intellectual formation is founded on the critique of modernism and the philosophy of the Enlightenment. ${ }^{24}$ Postmodern thought perceives

21 Leszek Nowak, Własność i władza, Vol. 1 (Poznań: Nakom, 1991), p. 244.

22 It is not accepted by John A. Hall who states that inventions essential for the functioning of a feudal social structure in the early Middle Ages: iron plough and mill have had been invented in the Roman times, but they themselves did not bring about a transformation of the social structures of the Roman Empire, see: John A. Hall, Powers and Liberties. The Causes and Consequences of the Rise of the West (Los Angeles: University of California Press, 1985), pp. 6-7.

23 Nowak, Power and Civil Society, p. 218.

24 I draw on a description provided by the following authors: Ted Benton and Ian Craib, Philosophy of Social Science: Philosophical Foundations of Social Thought (New York/ Basingstoke: Palgrave, 2001), pp. 171-173; Jerzy Szacki, Historia myśli socjologicznej (Warszawa: PWN, 2004), pp. 901-921. It is worth recalling Lorenz's description 
modernity as a formation dominated by rationalist fundamentalism, universalism, absolutism of the chosen truth, optimism, naïve trust in progress, admiration of science and technology, separation of the subject and object of cognition, exclusiveness, and contempt for inferior civilizations. The feature of modernity is generation of a metanarrative constituting its ultimate legitimization. Lyotard's notion of metanarrative is a very broad term encompassing not only universalistic religion but also great philosophical systems, such as Hegelianism and Marxism, and finally any theoretical system which attempts to grasp the variety and volatility of social reality within one formula. Lyotard distinguished between two types of metanarratives understood in the above sense: the narrative of emancipation and a substantial narrative. The former referred to the people in metaphysical terms and called for the necessity to liberate them by means of science. The latter referred to the Spirit instead of the people, and science was to be a tool of great synthesis. The characteristic feature of the current social development is the disappearance of metanarratives, since, as Lyotard points out, "the most people lost the nostalgia for the lost metanarrative." ${ }^{25}$ This state of affairs was partially influenced by extra-cultural, partially intra-cultural factors. In the present post-industrial society the majority of people is placed in the role of consumers, while the greater part of society is employed in the service sector. Individuals are becoming less and less attached to one occupation or place of residence. In all societies, the circulation of information and access to it have become crucial. There has also been a remarkable increase in the power of the mass media, which constantly produce images serving as substitutes of a direct

according to which the intellectual in question formation is characterised by the following three features: anti-reductionism combined with anti-unitarianism and antiobjectivism. The initial two features bring about distrust toward any metanarratives in history and a rejection of any possibility of reducing pluralism present in history to a unity. At the same time, however, anti-objectivism rejects the idea that there is a reality independent from its symbolic (particularly linguistic) representations. According to Lorenz, the above trends have been independently developed in the modern thought, and only their postmodern combination is original; see: Chris Lorenz. "'You got your history, I got mine.' Some Reflections on Truth and Objectivity in History," Österreichische Zeitschrift für Geschichtswissenschaften, Vol 4 (1999) p. 563. On the theoretical interpretation of postmodernism, see also: Leszek Nowak, "On Postmodernist Philosophy: An Attempt to Identify its Historical Sense," in: The Postmodernist Critique of the Project of Enlightenment, ed. Sven-Eric Liedman (Amsterdam/Atlanta: Rodopi, 1997), pp. 123-134.

25 Jean-François Lyotard, The Postmodern Condition. A Report on Knowledge (Manchester: Manchester University Press, 1984), p. 41. 
view of the world, thereby creating a virtual reality for the receivers. A homogenous cultural canon is now replaced with pluralism of cultures, ideologies, and language games, of the same significance. This brings about a crisis of a social identity because traditional social entireties, such as nation, class, Church, state, have become disintegrated. This state of affairs is designed to lead to the atrophy of all metanarratives, which have so far enabled individuals to integrate separate aspects of their existence into one whole.

Lyotard's claim about the disappearance of metanarratives may be understood at least in three different ways:

- ontologically - the nature of the historical process does not allow for the construction of a metanarrative;

- normatively - metanarratives should not be constructed;

- sociologically - nowadays, scholars and intellecutals do not construct metanarratives. ${ }^{26}$

Let us note that Lyotard's claim interpreted ontologically can be criticized the same way as Popper's thesis: Lyotard formulates a claim about the impossibility of constructing a metanarrative based on statements belonging to a type of metanarrative, that is to say, the postmodern metanarrative. If, and to what extent, the said metanarrative is accurate is yet another question. At the same time, however, Lyotard's claim understood in normative terms - adopting an assumption that a metanarrative is morally suspicious since it brings about unfavorable (totalitarian) social consequences - entails the very same theory of social consequences, namely, an idealistic theory of totalitarianism, which can be expressed in the following way: the construction of metanarratives brings about the emergence of totalitarian systems and so it itself belongs to the metanarrative questioned by Lyotard. ${ }^{27}$

Nonetheless, the easiest way to prove the fallacy of Lyotard's statement interpreted sociologically is to search the online database of a large university library by typing the term "philosophy of history." Randal Collins called the

26 I draw on slightly modified criteria allowing for a distinction between three types of nomothetism and idiographism presented in: Jerzy Malewski and Jerzy Topolski, "The Nomothetic versus the Idiographic Approach to History," in: Idealization XIII: Modeling in History, ed. Krzysztof Brzechczyn (Amsterdam/New York: Rodopi, [1960] 2009), pp. 299-310.

27 For the above reconstruction, see: Leszek Nowak, Byt i myśl. U podstaw negatywistycznej metafizyki unitarnej, Vol. I: Nicość i istnienie (Poznań: Wyd. Zysk i S-ka, 1998), pp. 13-21. 
period from the mid-1960s to the mid-1990s a golden age in the development of macro-history (or comparative historical sociology). ${ }^{28}$ During that period, the following works were published: Barrington Moore, Social Origins of Democracy and Dictatorship; Immanuel Wallerstein, The Modern World-System, vols. I-III; Theda Skocpol, State and Social Revolutions; Charles Tilly, Coercion, Capital, and European States, AD 990-1990; Ernest Gellner, Sword, Plough and Book. Structure of Human History; and others. ${ }^{29}$

\section{On the Teleology of Substantial Philosophy of History}

The critique of substantial philosophy of history formulated quite recently by Aviezer Tucker, who claims that a constitutive feature of such philosophy of history is the answer to the question of meaning (sense, goal) of history. As a result, all philosophers of history who provide answers to this question seek to occupy a privileged position in the historical process:

From the temporal vantage point of the end of the process, whether it is linear or cyclical, it is possible to discern its direction and meaning. Therefore philosophies of history from Hebrew prophets to Fukuyama through Vico, Hegel, Marx, Toynbee, and Kennedy have had to include apocalyptic themes in their philosophy to justify their claim to understand the whole historical process. ${ }^{30}$

The apocalyptic theme consists in a conviction of the end of history as we know it, one that defines the course and meaning of the historical process. According to Tucker, however, philosophers of history have no privileged position and their works are not a reflection of the self-consciousness of history; at most, they constitute a useful tool in understanding the intellectual history of their times. The time when various philosophies of history gain popularity, it is marked by periods of discontinuation and radical social change. It is then that mainly religiously oriented people ask questions like: where are we going and where have

28 Randal Collins, Macrohistory. Essays in Sociology of the Long Run (Stanford: Stanford University Press, 1994), p. 3.

29 Barrington Moore, Social Origins of Democracy and Dictatorship (Boston: Beacon Press, 1966); Immanuel Wallerstein, The Modern World-System (New York: Academic Press, 1974); Theda Skocpol, State and Social Revolutions (Cambridge: Cambridge University Press, 1979); Charles Tilly, Coercion, Capital, and European States, AD 990-1990 (Cambridge, Mass., USA: Blackwell, 1990); Ernest Gellner, Sword, Plough and Book. Structure of Human History (Chicago: University of Chicago Press, 1989).

30 Aviezer Tucker, Our Knowledge of the Past: A Philosophy of Historiography (Cambridge: Cambridge University Press, 2004), p. 16. 
we come from? Does history have a meaning? Answers to these questions may be found in various philosophies of history, even though, as Tucker claims, there is no scientific answer to be found.

It seems that the author unnecessarily combines two different characteristics shared by philosophies of history, which do not have to go together: the final stage and meaning (sense, goal, or value) of history assumed by a given philosophy of history. These two categories have been defined differently and they are logically independent. ${ }^{31}$ Crossing the two criteria, we may obtain four types of conceptions in substantial philosophy of history (listed in the table below).

Tab. 1: Types of substantial philosophies of history

\begin{tabular}{lll}
\hline Philosophy of History & Teleological & Non-teleological \\
\hline Finalistic & F and T (i) & F and N-T (ii) \\
Non-finalistic & N-F and T (iii) & N-F and N-T(iv) \\
\hline
\end{tabular}

Finalistic-teleological conceptions (i) assume that history leads to some kind of final stage, which is somehow valorized. Depending on the kind of valorization of the final stage of the historical process, we may distinguish between optimistic and pessimistic finalistic-teleological conceptions. Optimistic versions include the conceptions of such great thinkers as Augustine of Hippo, Comte, Kant, Hegel, Marx, and Fukuyama. ${ }^{32}$ The most popular finalistic-teleological substantial philosophy of history in the pessimistic version is, for example, Spengler's conception.

We may also distinguish finalistic and non-teleological conceptions (ii), i.e. conceptions that assume some kind of final stage of history but cannot define the sense of history. Here belong some catastrophic theories, namely those of consequential catastrophism, according to which the decline of the world as we know it and the associated system of values is inevitable. ${ }^{33}$ However, the predicted total

31 For different concepts of the sense of history, see: Buksiński, "Czy historia ma sens?", and for different concepts of the end of history, see: Ewa Domańska, "On Various Ends of History," Journal of the Interdisciplinary Crossroads, Vol. 1, No. 2 (2004), pp. 283-292.

32 Based on the characteristics of concepts of historical processes offered in: Wichrowski, Spór o naturę procesu historycznego, pp. 100-101.

33 According to Leszek Gawor, that view of catastrophism was shared by two Polish thinkers of the interwar period: Marian Zdziechowski and Stanislaw I. Witkiewicz, see: Leszek Gawor, Katastrofizm konsekwentny. O poglądach Marian Zdziechowskiego i Stanislawa Ignacego Witkiewicza (Lublin: Wyd. UMCS, 1998). 
catastrophe of the world is not fulfilment of any underlying sense or the goal in history.

Non-finalistic and teleological conceptions (iii) include philosophies of history assuming that socio-historical reality is unchangeable or those that adopt a cyclic view of history. The latter allowed for some kind of restricted historical changes embedded in repetitive and generally inflexible developmental cycles. Polybius, Plato and the stoics developed that view of history popular in Antiquity. According to them, the meaning of history consisted in unveiling the essence of lasting phenomena, i.e. human passions, characters of nations, the laws of the Logos. ${ }^{34}$

Non-finalistic and non-teleological conceptions (iv) assume the invariability (or a cyclic model) of history and negate any characterization of the goal of history. This type of orientation in philosophy of history did not yet lead to the emergence of fully-fledged theories of the historical process..$^{35}$ One can presuppose that conceptions inspired by the chaos theory belong to this kind of reflection in the substantial philosophy of history.

As demonstrated above, Tucker's objections hold true solely for finalistic and teleological conceptions of the philosophy of history. Conceptions of type (ii) and (iii), and particularly non-finalistic and non-teleological conceptions of type (iv), do not fall under Tucker's critique. Therefore, a question arises whether they belong to the substantial philosophy of history in Tucker's understanding. Namely, he assumes that a defining feature of conceptions belonging to this domain of philosophy is their reliance on finalistic (in an apocalyptic version) and teleological motives. Tucker's definition seems to be at least arbitrary. Apocalyptic motives are not a constant feature of substantial philosophy of history. They only emerged at a given time in the development of philosophy of history. According to Norman Cohn, until ca. 1500 BC the peoples of the Middle East believed in the existence of a stable and organized world. However, it was always under a threat from the forces of disorder of natural or supernatural origin. In the cosmogonic combat myth, the conflict between the forces of order and the forces of chaos acquired a symbolic dimension. Between 1500-1200 BC, the apocalyptic myth became popular thanks to Zarathustra - the forces of evil will be finally defeated and a new order will be created on the earth, and there will be no misery or suffering. ${ }^{36}$

34 Buksiński, “Czy historia ma sens?”, p. 102.

35 Wichrowski, Spór o nature procesu historycznego, p. 101.

36 Norman Cohn, Cosmos, Chaos and the World to Come. The Ancient Roots of Apocalyptic Faith (London: Yale University Press, 2001). 
Moreover, it is difficult to agree with the claim that the existence of ethical values determines the non-scientific and speculative character of the philosophy of history. Thus, the mere presence of values in the cognitive process does not determine the speculative character of the substantial philosophy of history but the possible functions that these values fulfill: heuristic or argumentative. Ethical values play a crucial heuristic role in formulating a problem under investigation, constructing initial model of a theory, or in its later developments. However, the subsequent process of substantiating the theory should proceed according to standard scientific procedures. The theory should be amended in case any discrepancies between theoretical outcomes and empirical data are detected. Usually, changes to the theory are made as a result of considering the influence of some factors, which had been ignored in its previous version.

The procedure looks different when the ethical values assumed by a given theory play an argumentative role. In that case, actual data inconsistent with the system of values adopted by a given theory are discarded and ignored by its author. Historiographic analyses and investigations merely serve the purpose of proving the truth and ethical value of the theory of the historical process. Here, the normative level of the theory, which describes the world as it should be and does not allow for the existence of any empirical reality inconsistent with the adopted system of values, is mixed with the descriptive level, which renders the world as it is. However, it must be noted that mixing descriptive and normative themes is not unique to the philosophy of history - it is actually present in many theories belonging to the humanities.

As demonstrated above, in his critique of theoretical history, Tucker - similarly to the above-mentioned Berlin - rightly captured the characteristics of some theories of the historical process but he erroneously ascribed them to the entire domain of the substantial philosophy of history.

\section{On the Need for the Theory of the Historical Process}

Isaiah Berlin and Aviezer Tucker both make the mistake of taking a part for the whole (pars pro toto). They distinguish certain characteristics (schematism and teleology, respectively) of the substantial philosophy of history, viewed as disqualifying, and ascribe them to the entire literature belonging to this philosophical domain. Whereas by treating the above features as a criterion for classification of the theory of the historical process, we will discover that only some of the theories have these features, while others do not.

Although Berlin criticized schematism and universalism of the substantial philosophies of history, one can observe an interesting paradox. As it turns out, 
liberal philosophy of history is not free from universalism, a charge eagerly made by the supporters of liberalism against its ideological adversaries. ${ }^{37}$ Rostow's theory, which has been treated as an alternative to the vision of history presented by the authors of The Communist Manifesto, adopts a universalistic view on the past ignoring civilizational diversification.

The same vision of the past is present in a number of various theories of modernization, which are currently being developed, claiming spread of industrial market economy and democratic welfare state institutions on a global scale. Francis Fukuyama explicitly adopted the universalistic approach in his work on the liberal end of history. Fukuyama understands history in a Hegelian way, as a "single, coherent, evolutionary process, when taking into account the experience of all people in all times." 38 This vision of history is not only universalistic but also finalistic. According to Fukuyama, the history of human kind does not evolve ad finem, but it will end when the most essential needs are satisfied. Then "there would be no further progress in the development of underlying principles and institutions, because all of the really big questions had been settled." 39

This brief presentation of the conceptions concerning the theory of historical process allows one to draw three conclusions. First, the deep structure of the theories under analysis is independent from its content. The theories of both Marxist and liberal provenance adopt a universalistic view of history. Interestingly, it appears that a number of liberalistic conceptions of history may become more dogmatic than the Marxist theories (allowing for a multi-variant approach to the historical development). Second, the universalistic vision of history is not the only structure of discourse present in substantial philosophy of history. At the other end of the spectrum, there is the pluralistic variant of the theory of the historical process, which posits the presence of many civilizations evolving in accordance to various developmental mechanisms. Finally, the inclusion of other aspects of the substantial philosophy of history, i.e. of teleology and finalism, demonstrates that this field of the humanities is even more diversified. Explanatory, normative, and prognostic threads entwine in varying proportions in theories belonging to this philosophical area. As a result, to accuse substantial

37 The above paradox was recognized in: Nowak, "On Postmodernist Philosophy," pp. 11-13.

38 Francis Fukuyama, The End of History and the Last Man (New York: The Free Press, 1992), p. xii.

39 Fukuyama, The End of History, p. xiii. 
philosophy of history in toto of uniformization of the historical process is to imply uniformity, which proves incomprehension of this field of the humanities.

In turn, Popper and Lyotard found their charges on tacitly adopted claims belonging to the very scientific field they criticize. Popper draws his arguments on the impossibility to formulate prognoses from the idealistic philosophy of history, while Lyotard's arguments concerning the loss of interest in metanarratives are based on a certain characteristic of contemporary society, which itself belongs to the metanarrative questioned by him, which may or may not be shared.

However, there is some truth to Lyotard's statement about the disappearance of nostalgia for metanarratives. Lyotard points to the social conditioning of the demand for metanarratives or its lack, and not to the state-of-the-art social sciences and humanities. For this reason, one may recognize that the loss of nostalgia for metanarratives is socially conditioned and as such seems to be more of a temporary than a permanent character. In a period of social stabilization, the demand for metanarratives is dropping. Public life becomes repetitive and predictable. People no longer ask philosophers of history for explanations of their social reality because they are perfectly able to understand it themselves. Metanarratives, if anyone cares to create them at all, are presented at boring academic conferences and published in professional journals by specialist publishing houses. They do not make the headlines in newspapers or on television. In times of crisis and social disturbance, when - to use Arnold Toynbee's metaphor - history speeds up, the situation looks completely different. It is then that people lose their social orientation and no longer know what tomorrow brings. Then there comes a time for a philosopher of history because, in such social conditions, an intellectual demand for metanarratives is rapidly increasing. Whether that demand will be satisfied or not depends on the existence of previous metanarratives capable of explaining the volatility of the social world which had already been created in the times of social silence. The rule outlined above at least partially explains the origins of the work, which initiated philosophical reflection on history, at least in our civilization. On 24th August 410, the army of Visigoths headed by Alaric I conquered and sacked Rome. For people living at the time, this traumatic experience can be compared to the September 11 attacks in the USA. Then arose a need to understand the reasons for defeat. In general, people sought the reasons for misery in the vengeance of the Roman gods who had been abandoned by the Romans. Interestingly, Christians, despite their belief in one God, adopted this view and even attributed existence and certain causative power to Roman gods. It was in this intellectual atmosphere that Augustine of Hippo, at the instigation of Marcellinus, a high-ranking Roman official, begun working on the first three volumes of De Civitate Dei, aimed at demonstrating 
the fallacy of the above-mentioned views. In the years 410-426, his work grew to 22 volumes presenting a view of history alternative to the one expressed in Antiquity, and which has been largely preserved until the 18th century. ${ }^{40}$ We may likewise explain the popularity of Lyotard's claim put forward in The Postmodern Condition of 1979. The book was written at a time of stability in Western countries - the first signs of crisis in the welfare state were not fully visible at the time, there was a period of détente between the USA and the Soviet Union concluded with the latter's invasion on Afghanistan in December 1979. The Solidarity revolution in Poland was yet to break out, and the anti-modernizing and anti-American consequences of the Iranian revolution undermining the American hegemony in the Third World were still to display themselves (the occupation of American embassy took place in March 1980). Nostalgia for metanarratives increased after the fall of communism between 1989 and 1991. It was no coincidence that Fukuyama's The End of History, which offered an interpretation of the events that had taken place in the Eastern block in the Hegelian terms, gained so much popularity in the first half of the 1990s. Similarly, the increasing confrontation between the West and the Islamic world brought about a growing popularity of the claims presented in Samuel's Huntington's The Clash of Civilizations at the beginning of the 21 st century. The concept of the civilizational conflict has by now become a journalistic cliché used to explain both terrorist attacks and Western policy against Arab states. Is it possible to live without metanarratives? It does not seem so. Moreover, in the current logic of social development, the actions of individuals, groups, classes, and societies equipped with the latest technologies generate social consequences of scale, which has been unthinkable until now. In an increasingly globalized world, human activity in one corner of the world brings about unexpected and frequently adverse consequences in another part of the world. In a world of growing interdependencies, the demand for great-scope social theories is expected to increase because such theories enable us to predict and explain the consequences of human actions. Whether the increase in cognitive demand for metanarratives will meet intellectual supply is yet another issue.

40 Augustine of Hippo, The City of God (Overland Park, Digireads.com Publishing, 2017). 



\section{The Concept of Central Europe}

\section{Introduction}

The purport of the present chapter is to outline the principal threads in a discussion concerning the status of Central Europe, its borderlines, and the nature of the developmental distinctiveness of this part of the continent. I adopt Jerzy Topolski's claim that a historical region may, but does not have to, match a territorial entity distinguished geographically. The above takes place when:

an element of human activity and its consequences is added to a geographical characteristic of a region (or to pointing out the differences between the region and other similar spatial entities). Following from this, there are three elements required to distinguish a historical region: space, time, and a human being and his activity. ${ }^{41}$

Thus, in Topolski's view, the principal criterion for distinguishing a historical region is the common life of a society of human beings on a given territory and its creations, which have to differ to some extent from the outcome of human life on a different territory. Following from this, the results of human activity include: economic, political, and cultural assets created by human beings, a social-class structure, in which the activity is undertaken, and forms of social awareness accompanying the activity. Topolski defines a historical region in the following way:

[It] is a concept, whose theoretical structure combines a defined territory inhabited by a given number of people who share a common history (short or long), which differs somehow from the history of other territorial/population entities of this type. Thus, it is understood as a certain comprehensive system (a structure), characterized by own historical identity (and sometimes by distinctive administrative borders), combining geographical, economic, social, political-administrative, cultural, and psychical elements (with separate elements that have a variable importance in various periods). ${ }^{42}$

The operation of distinguishing historical regions may be analyzed on two planes: cognitive and pragmatic. The cognitive plane determines the research usability of a given region to explain collected empirical facts or the ability to inspire future source studies. The pragmatic plane, in turn, determines the functionality of a given region against the interest of social classes: rulers, owners,

41 Jerzy Topolski, Jak się pisze i rozumie historię. Tajemnice narracji historycznej (Warszawa: Rytm, 1996), p. 146.

42 Topolski, Jak się pisze, pp. 147-148. 
and priests, and certain complex social entireties, such as national societies and entire civilizations (i.e. European civilization).

Let us now use the above conclusions to interpret the principal threads in the discussion over the status of Central Europe and the sources of its differentiation.

\section{On the Criteria of Distinguishing Central Europe}

Traditionally, the Central-European region is distinguished using two separate sets of criteria: geographical and historical/civilizational. These criteria can be used in a cognitive and a pragmatic manner. The geographical criterion considers the following features: landscape, climate, and fauna and flora. The set of historical/civilizational criteria includes the following variables: type of economy, type of political system, model of culture, and ethnic and religious composition of the population that inhabits a given territory. The division of European societies based on the set of historical/civilizational criteria include a division along the circles of latitudes (along the North-South axis) and the circles of longitudes (along the East-West axis). The Central-European region is distinguished only in the latter division.

Let us analyse the pragmatic manner of the use of the notion of "Central Europe." This term first appeared in the German scientific and political literature in the beginning of the 20th century where it performed a predominantly non-cognitive function, serving as a justification of the German imperial foreign policy. ${ }^{43}$ A Central-European Association was established in Berlin in 1904 with a task to bring about an economic unification of Germany and Austria-Hungary. Joseph Partsch was one of the first authors who attempted to distinguish the Central-European region. He claimed that the region covers the territory spreading from Western Alps and the Balkans to the English Channel and the Curonian Lagoon, and from the Rhine to the Vistula River, and even the Dnieper River. However, in Partsch's division, the borders of Central Europe matched the political borders encompassing the German Empire, the Austro-Hungarian monarchy, Holland, Belgium, and Switzerland, and on the south: Romania, Bulgaria, Serbia, Bosnia, and Montenegro. ${ }^{44}$

43 Gerard Delanty, “The Historical Regions of Europe: Civilizational Backgrounds and Multiply Routes to Modernity," Historicka Sociologie, Nos. 1-2, (2012) pp. 15-16.

44 Joseph Partsch, Mitteleuropa. Die Lander und Volker von den Westalpen und dem Balkan bis an den Kanal und das Kurische Haff (Gotha: J. Perthes, 1904). 
Friedrich Naumann popularized the idea of a union between the AustroHungarian Empire and Germany during the First World War. According to his concept, Central Europe was a territory

"which extends from North and Baltic Seas to Alps, the Adriatic Sea and the southern edge of the Danubian plain. Take a map and see what lies between Vistula and the

Vosges Mountains and what extends from Galicia to Lake Constance!"45

The discussed region was supposed to be an economic and political union bound by a military alliance between Berlin, Vienna, and Budapest, with an ensured dominance of Prussia and the German nation. The defeat of Prussia in the First World War and the dissolution of the Austro-Hungarian Empire brought an end to the concept of the German hegemony in the region. During the interwar period, Central-European integration was, in fact, limited to a cooperation under the Little Entente, an alliance formed by the successor states of the Austria-Hungary and France, aimed at preventing the revision of borders by Hungary. Even more vague was the Polish idea of Intermarium, or the project of a Polish-Czechoslovakian federation. ${ }^{46}$

After the Second World War, the notion of "Central Europe" was replaced with the concept of Eastern Europe covering USSR and the countries of the Eastern Block: Bulgaria, Czechoslovakia, the German Democratic Republic, Poland, Romania and Hungary - members of the Council for Mutual Economic Assistance and the Warsaw Pact, who were supposed to work together to build the system of real socialism modeled on the Soviet example. During the cold war, the European continent was divided into East and West, with no place for local distinctiveness. The processes of de-Stalinization, which took place after 1956 and were most advanced in Poland, Hungary, and Czechoslovakia, reintroduced the notion of "Central Europe" into intellectual circles. Milan Kundera promoted the region in the 1980s with his famous essay The Tragedy of Central Europe. ${ }^{47}$

Political perturbations associated with the use of the notion of "Central Europe" notwithstanding, the concept has also been employed in a purely cognitive sense.

45 Friedrich Naumann, Central Europe (London: P.S. King \& Son, Limited, 1916). On the concept of Central Europe in American historiography at the turn of the XIX and XX th century see: Tomasz Pawelec, $Z$ drugiej strony Antlantyku. 'Młodsza Europa'w dawnych syntezach amerykańskich (Cieszyn: PTH 2013), pp. 43-113.

46 Sławomir Łukasiewicz, Trzecia Europa. Polska myśl federalistyczna w Stanach Zjednoczonych 1940-1971 (Warszawa-Lublin: IPN, 2010).

47 Milan Kundera, "The Tragedy of Central Europe," The New York Review of Books (April 26, 1984), pp. 31-38. 
However, even in the cognitive context, it has been used in an ambiguous and vague manner. This resulted from the fact that the investigated region has been distinguished according to two separate sets of criteria: geographical and historical/civilizational, which blended together frequently. ${ }^{48}$ In this book, the thesis presented above will be illustrated with examples of divisions of Europe made according to geographical criteria (Józef Wojtanowicz), geographical/civilizational criteria (Garrison Walters), and historical/civilizational criteria (George Schöpflin, Oskar Halecki, Peter Burke, Jeno Szűcs, Piotr Wandycz, Antoni Podraza). The above-mentioned types of divisions may appear in a dichotomous (adopting a division into East and West) and trichotomous variant. In the dichotomous variant the specific character of Central Europe disappears and this part of continent is treated as part of the East. The trichotomous variant allows for distinguishing Central Europe with reference to geographic criteria, histor$\mathrm{ical} /$ civilizational criteria, or both.

It is noteworthy that even by restricting the argument to geographical criteria, one does not necessarily receive an unambiguous definition of notion of "Central Europe." Karl Sinnhuber compared maps of Central Europe created by twelve geographers from Great Britain, Germany, and France. It turned out that Czechoslovakia was the only country, which appeared on all of the maps, and Portugal and Spain were the only two countries that all geographers agreed to exclude from the map of Central Europe. ${ }^{49}$

Józef Wojtanowicz proposed an example of a recognition of Central Europe based entirely on the application of geographical criteria. He divided the European continent into four parts: eastern, western, southern, and northern. Eastern Europe spreads east of the rivers Dnieper and Daugava; Northern Europe covers the Scandinavian Peninsula, Iceland, and an area roughly matching the territory of Estonia; Southern Europe lies south of the Pyrenees, the Alps, and the line of the rivers Sava and Danube; finally, Western Europe covers the terrains west of Rhine, and north of the Alps and the Pyrenees.

48 Cf. Endre Bojtár, "Eastern of Central Europe?” Cross Currents. A Yearbook of Central European Culture, No. 7 (1988), p. 1; Danilo Kiš, "Variations on the Theme of Central Europe," Cross Currents. A Yearbook of Central European Culture, No. 6 (1987), p. 1; Geörgy Konrád, "Is the Dream of Central Europe Still Alive?" Cross Currents. A Yearbook of Central European Culture, No. 5 (1985), p. 109; Robin Okey, "Central Europe/Eastern Europe: Behind Definitions," Past and Present, No. 137 (1992), p. 103.

49 Karl Sinnhuber, "Central Europe, Mitteleuropa, L’Europe Centrale: An Analysis of a Geographical Term," Transactions and Papers, Vol. 20 (1954), pp. 17-18, 20. 
Central Europe covers the terrain between two major narrowings of the European continent - the Baltic-Black Sea passage and the North-Adriatic passage. The distinctive features of the region include transitional climate and mosaic landscape, developed in the Neo-Pleistocene. The following geological forms appeared during glacial periods: moraines, kames, eskers, outwash plains, and Urstromtäler. Stone runs were a characteristic landform. Wojtanowicz divides Europe into the following four zones with reference to climate: "cold Scandinavian North, Mediterranean South, Atlantic West, and continental East. Between them lays a central part, not the smallest one, which cannot be included into any of the parts listed above. It is Central Europe." ${ }^{50}$

A reliable indicator used to define the territory of Central Europe may also be the duration of frost lasting between two and four months. The region is currently characterized by a large geographical diversification, a variety of landscapes, and a diverse climate. Mixed forests prevail in the area under study, which favor the development of brown and podzolic soils, but there are also wetlands (Polesia) and forest steppe. This transitional character of Central Europe prevents a clear determination of its boundaries. However, in Józef Wojtanowicz's opinion:

Central Europe borders with the Baltic Sea and the North Sea in the north, and it reaches the Black Sea in the southeast. The rivers confine its terrain: Rhine on the west, DnieperDaugava on the east and Danube-Sava on the south, and in the southwest it is limited by the ridge of Alps. The largest, or one of the largest rivers, and the highest European mountains determine the borders of Central Europe. ${ }^{51}$

Garrison E. Walters provides an example of a division according to two sets of criteria - geographical and historical/civilizational..$^{52} \mathrm{He}$ founds his division on a contrast - features and properties absent from Eastern Europe characterize the developmental path of Western Europe, and all the way round. According to Walters, the distinction between the East and West of Europe hinges on geographical differences.

Western Europe was characterized by a warmer climate, heavier rainfall, longer vegetation period of plants, more accessible navigable waterways and a possession of natural, easy to defend borders. As a result, Western-European agriculture was more productive and more efficient compared to Eastern-European

50 Józef Wojtanowicz, "Europa Środkowa jako region fizyczno-geograficzny - podstawy wydzielenia, granice," Przeglad Geograficzny,” Vol. 52, No. 3 (1999), pp. 217.

51 Wojtanowicz, "Europa Środkowa," p. 218.

52 Garrison E. Walters. The Other Europe. Eastern Europe to 1945 (Syracuse: Syracuse University Press, 1989), pp. 111-113. 
agriculture. A longer shoreline and rivers navigable during most days in a year lowered the cost of transport in Western Europe. This, in turn, considerably contributed to the development of economy and the intensification of trade. Western-European societies easily defended against external aggressions due to natural water borders. Eastern-European societies developed under different conditions. More severe and longer winters, together with lower rainfall, created inferior conditions for the development of agriculture. A less-developed system of rivers hindered the communication between various parts of Eastern Europe. Moreover, natural borderlines did not protect Eastern-European societies against aggressive attacks of nomadic tribes. The above geographical/climate differences exerted an influence on the economic advancement of the two parts of the continent. In turn, geographical factors combined with economic advancement exerted an influence on political development and determined the formation of individual political systems in two parts of the continent. Culture and the model of education were common for entire Europe. Culture comprised of a certain common set of values present in philosophy, art, literature, and music. Church institutions were responsible for schooling in European countries - the Catholic Church and Protestant churches in Western Europe, and the Orthodox Church in Eastern Europe. The era of the Enlightenment initiated the process of gradual secularization of schooling in the 19th century.

George Schöpflin offers a similar dichotomous division of Europe, but it is based solely on historical/civilizational criteria:

From the earliest period onwards, the West gradually evolved toward a position that power should be divided, that the different areas of power should be separated and the ruler should not be absolute either in his power or in his legitimization. The peculiarity of the Western pattern of development lay in separation of religious and secular legitimization. ${ }^{53}$

The competition between the Church and state made possible for third parties to emerge. In the consequence of tensions between secular and spiritual power, towns flourished and gained autonomy. The merchant estate became a decisive factor in social life, counterbalancing the influence of nobility. As Schöpflin points out:

In West European development a key role in evolution of autonomous organization and power was played the existence of a fairly dense network of towns. The West European

53 George Schöpflin, "The Political Traditions of Eastern Europe," in: Eastern Europe. . Central Europe. . . Europe, ed. S.R. Graubard (San Francisco/Oxford: Boulder/Westview Press, 1991), p. 61. 
town was a unique phenomenon in a number of ways - most significantly in its ability to develop autonomously of the ruler and the Church and to create specific political techniques intended to safeguard the basis of this autonomy, namely trade..$^{54}$

Another aspect of the Western development path was emancipation of scientific activity from the tutelage of Church. The freedom of speech and thought was based on the concept of autonomy of universities, which started in the Middle Ages. In consequence - Schöpflin maintains - the characteristic feature of Western development was the following conviction:

The ruler was constrained to recognize that he did not exercise absolute power over his subjects, who retained politically, economically, etc. important spheres of autonomous action. Despite repeated attempts by various rulers - religious as well as secular - to extinguish or suppress these spheres of autonomy, whether in the name of order or routine or unity or rationalization, these were never completely successful. Autonomy and the separation of spheres remained a crucial feature of Western patterns and subsequently became the foundation for the extension of liberties. ${ }^{55}$

Eastern Europe took a different path of development. First of all, this part of Europe inherited Byzantine tradition of subordination of church by state. In addition, the towns in the East were weaker, and town dwellers were less numerous and less independent. Eastern towns served as a seat of administration or a garrison town. Therefore, unlike in Western Europe, the merchant estate was not able to counterbalance the nobility and state power. This social structure led to bigger concentration of power in the hands of state bureaucracy (Hapsburg empire) or the dominant social class (Poland, Hungary). The civilizational backwardness of Eastern Europe brought about its intellectual dependency on the West. As Schöpflin recognizes:

The backwardness of Eastern Europe vis-a-vis Western Europe, both real and perceived, had further ramification for political development. From the outset of the modern period, the late Enlightenment to the middle of the nineteenth century, East European elites took Western Europe as their criterion of modernity. It was immediately obvious that the task facing East European societies was to effect modernization. But the definition of this and the means to this end were not so obvious. Indeed, the East European elites tended to oversimplify the task by assuming that political and economic development to West European levels could be achieved quickly and by the practice of adopting West European political forms regardless of their local appropriateness. ${ }^{56}$

54 Schöpflin, "The Political Traditions," p. 71.

55 Schöpflin, "The Political Traditions," p. 63.

56 Schöpflin, "The Political Traditions," pp. 67-68. 
Under the conditions of no civil society, the state took on itself the task of modernization. This resulted in further social repercussion. The primary concern of state bureaucrats was the wellbeing of state machinery. Therefore, investments were allocated in military spheres or consumed by bureaucracy itself. As a result, a state-stimulated modernization was distorted. It did not bring about the emergence of a civil society, but strengthened the bureaucratic structures. In conclusion of his comparison of the West and the East of Europe, Schöpflin ascertains:

The Western political tradition always emphasized pluralism and the fragmentation of power. In Eastern Europe, which was politically backward, the state played a much more dominant role as the principal agent of change. This resulted in a politically preeminent bureaucracy and a weak society. ${ }^{57}$

After the Second World War, a Polish historian Oskar Halecki became the pioneer in American historiography of distinguishing Central Europe, apart from the West and the East. His view stemmed from a dichotomous division into Western and Eastern Europe. The division was, however, embedded in civilizational and not geographical grounds: a division into Rome and the Byzantine Empire, subsequently reinforced by the division into Catholicism and Orthodoxy. Halecki did not find the religious criterion to be sufficient, because he believed that:

Chronological divisions in history cannot be founded on stand-alone dates, but have to consider short and long transitional periods. Correspondingly, territorial divisions cannot ignore the existence of narrow and wide "transitional" passages, where cultural borders are always subject to fluctuation. It is a phenomenon typical for historical geography, a science, which has to take human evolution into consideration. One has to remember about it, when attempting to receive a clear definition of Europe as a whole, and of its individual regions. ${ }^{58}$

Halecki divided Europe into four regions: Western Europe, West-Central Europe, East-Central Europe, and Eastern Europe..$^{59}$ Western Europe included countries subjected to the Roman rule, the northern part of Great Britain, Ireland, and the Netherlands. West-Central Europe encompassed Germany, Switzerland and Austria; and East-Central Europe included twelve countries situated between Scandinavia, Germany, Italy, and Russia. The latter country belonged to Eastern Europe.

57 Schöpflin, “The Political Traditions," p. 59.

58 Oskar Halecki, Historia Europy - jej granice i podziały (Lublin: Instytut Europy Środkowo-Wschodniej, 1994), p. 132.

59 Halecki, Historia Europy, p. 163. 
The view presented by Peter Burke also originates from a dichotomous division based on historical/civilizational criteria. ${ }^{60}$ According to Burke, the territories of Western Europe were characterized with a higher level of population density, the domination of Roman and Germanic languages, and the supremacy of Catholicism and Protestantism. Additionally, the first components of a capitalist economy appeared in the region as early as in the 16th century. According to Burke's division, a lower level of population density characterized the terrains of Eastern Europe. Moreover, Slavic languages dominated the terrains and Orthodoxy was the predominant religion. Additionally, this region experienced an introduction of second serfdom and the development of a manorial-serf economy in the 16th century. Nonetheless, Burke claims the two-fold division to be insufficient. He proclaims an intermediate terrain situated between the East and the West, Russia, and Germany. According to this division, the same features as Western or Eastern Europe characterize Central Europe, but the intensity of the features is different and it determined a developmental specificity of the region under investigation. As an example, Burke discusses the level of population density in Central Europe at the end of the Middle Ages. It was substantially higher, in comparison to the population density in Russia or Scandinavia, but it was lower than the population density in Western countries. In addition, Burke remarks that:

The power of the elected kings of Poland after 1572 was considerably less than that of, say, the tsar of Russia (...). Renaissance made relatively little impact on Russia and the Balkans, while (...) Hungary, Poland and Bohemia all participated actively in that movement. A similar point could be made about Reformation. Protestantism in various forms was a serious force in Bohemia, Poland and Hungary, as it was not in South-East Europe or in Russia. ${ }^{61}$

A trichotomous division, apart from Western and Eastern Europe, distinguishes East-Central or Central Europe (in this book, I shall consequently use the second term) is assumed, among others, by Jeno Szücs who emphasizes the "intermediate" character of Central Europe:

60 Peter Burke, "Introduction: A Note on the Historiography of East-Central Europe," in: Central Europe in Transition. From the Fourteenth to the Seventeenth Century, eds. Peter Burke, Antoni Mączak and Henryk Samsonowicz (Cambridge: Cambridge University Press, 1985), pp. 1-2.

61 Burke, "Introduction," p. 2. 
Structures of the Western type can be detected everywhere, although they were deformed to some degree: either incomplete (as the towns were, for example) or disproportionately overgrown (as was the nobility). ${ }^{62}$

Yet in terms of the basic elements one feels there is an argument for applying even in the Middle Ages the notion 'East-Central Europe' to the entire region, in which inclusion 'East' means that modifications to the structure of the Western type of models and norms could be detected in almost everything. Of course there were minor differences - Bohemia showed forms rather more "Western" than Hungary's and Croatia forms rather more archaic, while Poland was in most respects highly similar. $^{63}$

Piotr Wandycz offered a similar trichotomous division based on historical/ civilizational criteria. He lists a number of features defining the dissimilarity of Central Europe. ${ }^{64}$ The key features of the region definitely include its "civilizational youth" - it became part of the European civilization only in the 10th century. A civilizational delay resulted with disproportions in economic development between Central and Western Europe. Wandycz claims that the distance between the two parts of Europe was initially gradually decreasing. However, subsequently, at the turn of the 15th and the 16th centuries, the West evolved toward proto-industrialization, and Central Europe experienced an emergence of a manorial-serf economy. This led to another characteristic feature of the region, where backward socio-economic structures were no longer geared to the more advanced cultural and political development. An individual model of evolution of national consciousness was another feature of Central-European development. In Western Europe, a state created a nation. In contrast, in Central Europe a nation, understood as a social group sharing a common culture, created a state. For this reason, national minorities, such as Germans and Jews played a significant role in Central Europe. Long-lasting gaps in the development of statehood in Central-European societies brought about to a different model of shaping national consciousness. These gaps brought caused the history of Central-European nations to be filled with lengthy wars in defense of freedom or to regain freedom. ${ }^{65}$

62 Jeno Szücs, “The Three Historical Regions of Europe: An Outline," Acta Historica Academiae Scientiarum Hungaricae, Vol. 29, No. 2/4 (1983), pp. 154-155.

63 Szücs, “The Three Historical Regions," p. 156.

64 Piotr Wandycz, The Price of Freedom: A History of East Central Europe from the Middle Ages to the Present (London - New York: Routledge, 2001), pp. 5-10.

65 This aspect of the history of Central Europe has been analysed in: Janusz Żarnowski, "W sprawie genezy systemu państw narodowych w Europie Środkowej 
In a conclusion of the present recapitulation, it is noteworthy to discuss the division of Europe which is also based on historical/civilizational criteria offered by Antoni Podraza who attempted to combine the division along the circles of latitudes (along the North-South axis) and the division along the circles of longitudes (along the East-West axis). In the course of its history, Europe experienced three grand partitions. ${ }^{66}$ First, it was divided in Antiquity into the Roman Empire and the barbaric world, which spreaded north of Danube and east of Rhine. Since 395, the Roman Empire was experiencing a partition into an eastern, Hellenic part and a western part dominated by Latin and Roman influences. After the western part of the Empire fell in 476, the process of Romanization and Christianization of Germanic tribes took place. The monarchy of Charlemagne, who conquered and Christianized the Saxons in the second half of the 8th century, referred to the tradition of the Roman Empire. The river Elbe became the religious/cultural borderline at the turn of the 8th century.

As soon as Bohemia, Hungary (including Croatia), and Poland were Christianized, the division into Christian and pagan Europe, stemming from the division of the continent into "empire" and "barbarikon," finally disappeared. At that time, the second division symbolized by the Great Schism of 1054 took place. It was founded on cultural and religious differences between Orthodoxy and Catholicism. The eastern borders of Poland, Hungary, and subsequently Lithuania, Livonia and Finland became the borderlines of Western Europe. The new societies of the Western-European civilizational circle created a younger Europe characterized by absence of Ancient heritage and a delayed adoption of Christianity. In the 14th-15th centuries, these countries appeared to have reduced the civilizational backwardness to the Western-European countries. However, a third division took place during a transition from the Middle Ages to the Modern Era, founded on the difference in socio-economic relations. A capitalistic economy was initiated west of the river Elbe and a manorial-serf economy was established east of the river.

i Południowo-Wschodniej," Kwartalnik Historyczny, No. 3 (1970), p. 587; Piotr Machura, "Central-European Ethos: Equality, Social Emergence and Claims to Justice," in: Central-European Ethos or Local Traditions: Equality, Justice, eds. Jarmila Jurová, Milan Jozek, Andrzej Kiepas and Piotr Machura (Brno: Albert, 2011), p. 19.

66 Antoni Podraza, "Europa Środkowa. Zakres przestrzenny i historia regionu," Prace Komisji Środkowoeuropejskiej, Vol. 1 (1993), pp. 23-34. 


\section{On the Borders of Central Europe}

Another problem - next to the issue of determination of the criteria of division of the European continent into regions and the issue of distinguishing Central Europe - is a clear demarcation of borders. There are three methods of demarcation: maximalist, minimalist and intermediate. In the maximalist approach, Central Europe roughly covers an area between Russia and Germany on one side, and North Cape and Cape Matapan on the other. According to Tomáš Masaryk, a Czech statesman and philosopher, Europe can be divided into Western, Eastern (Russia) and Central part. The latter is:

a peculiar zone of small nations, extending from the North Cape to Cape Matapan. Side by side we here find the Laplanders, Swedes, Norwegian and Danes, Finns, Estonian, Letts, Lithuanians, Poles, Lusatians, Czechs, and Slovaks, Magyars, Serbo-Croats and Slovenes, Roumanians, Bulgars, Albanians, Turks and Greeks. The largest of these nations are Poles; next to them come the Czechs and Slovaks, Serbo-Croats, Roumanians, and Magyars: the others are smaller. If the Little-Russians (Ruthenes, Ukrainians) were considered a separate nation, as distinct from Great-Russians, they would be the largest nation of this zone. ${ }^{67}$

Jan Kofman also represents a maximalist variant of the geographical demarcation of Central Europe. According to him, Baltic Sea is the northern borderline of Central-East Europe, Black Sea and the Adriatic - the southern borderline, Germany and Italy - the western borderline, and the territory of the successor states of USSR - the eastern borderline. Central-East Europe includes Albany, Austria, Bulgaria, Czechoslovakia, Estonia, Yugoslavia, Greece, Lithuania, Latvia, Poland, Romania, and Hungary. In comparison with Masaryk, Kofman excludes the Scandinavian countries, Turkey, Greece and Ukraine, but he includes Austria. ${ }^{68}$ Jerzy Tomaszewski, in turn, treats Central and South-West

67 Tomáš Masaryk, "Pangermanism and the Zone of Small Nations," New Europe, No. 1 (1916), p. 272. On the shaping of Masaryk's views on the borders of Central Europe, see: Tadayuki Hayashi, "Masaryk's 'Zone of Small Nations' in His Discourse during World War I," in: Regions in Central and Eastern Europe: Past and Present, eds. Tadayuki Hayashi and Hiroshi Fukuda (Sapporo: The Slavic Research Center, 2007), pp. 3-20; Roman Szporluk, “Defining 'Central Europe:' Power, Politics and Culture,' Cross Currents. A Yearbook of Central European Culture, No. 1 (1982), pp. 30-38; and for an overview of various concepts of demarcation of this part of Europe, see: Jerzy Stańczyk, "Europa Środkowa - kryteria wyodrębniania i cechy regionu," Studia Polityczne, No. 12 (2001), pp. 197-211.

68 Jan Kofman, Nacjonalizm gospodarczy - szansa czy bariera rozwoju. Przypadek Europy Środkowo-Wschodniej w okresie międzywojennym (Warszawa: PWN, 1992) p. 224. 
Europe as a homogenous area, in terms of economy and politics, including Albany, Bulgaria, Czech Republic, Estonia, Finland, Yugoslavia, Lithuania, Latvia, Poland, Romania, Slovakia, and Hungary. ${ }^{69}$

In the minimalist tradition of demarcation of Central Europe, its territory is limited to areas that had been controlled by western Slavs and Hungarians in the past. For instance, Piotr Wandycz presents the history of Poland, Bohemia, and Hungary in his book on the history of Central Europe. ${ }^{70}$ In contemporary nomenclature, Central Europe spreads across member countries of the Visegrád Group.

A number of intermediate variants add either the territories inhabited by southern Slavs, or by Baltic nations: Latvia and Estonia, to the ingenious territory of Central Europe covering the area inhabited by western Slavs and Hungarians. Authors of such variants usually modify the adjective "Central" by adding two more: "East" or "South."71

For example, Peter F. Sugar and Donald W. Treadgold, editors of the book series "A History of East-Central Europe," define its borderlands in the following way:

The appropriateness of including the Finns, Estonians, Latvians, Lithuanians, Belarusians and Ukrainians was consider, and it was decided not to attempt to cover them systematically, though they appear repeatedly in these books. Treated in depth are the Poles, Czechs, Slovaks, Hungarians, Romanians, Yugoslav peoples, Albanians, Bulgarians and Greeks. ${ }^{72}$

69 Jerzy Tomaszewski, "Europa Środkowa i Południowo-Wschodnia: cechy charakterystyczne i granice regionu” Ekonomia, No. 16 (1976), pp. 129-130, 138-139. On the distinctiveness of the Balkans, see: Maria Todorova, Imagining the Balkans (Oxford: Oxford University Press, 1997), chapter 6.

70 Burke and Kirschbaum share a similar view, see: Burke, "Introduction," p. 1; Stanislav Kirschbaum, Historical Reflections on Central Europe (New York: St. Martin Press, 1999).

71 See i.e. the title of the book edited by Reginald R. Betts, Central and South East Europe, 1945-1948 (London: Royal Institute of International Affairs, 1950) who represents the intermediate variant, because he adds also to Central Europe: Bohemia and Moravia, Poland, Slovakia and Hungary, and to South-East Europe: Romania, Bulgaria, Yugoslavia. Jean Sedlar shears this view, and adds the following countries to SouthEast Europe: Albania, Bulgaria, Bohemia and Moravia, former Yugoslavia, Poland, Romania, Slovakia and Hungary, see: Jean W. Sedlar, "Introduction," in: East Central Europe in the Middle Ages, 1000-1500, ed. Jean W. Sedlar (Seatle/London: University of Washington Press, 1994), p. x.

72 Peter F. Sugar and Donald W. Treadgold, "Foreword," in: East Central Europe in the Middle Ages, 1000-1500, ed. Jean W. Sedlar (Seatle/London: University of Washington Press, 1994), p. vii. 
In Jerzy Kłoczowski's opinion, Central Europe covers the territory of former Republic of Poland, Bohemia, Slovakia, Hungary, Slovenia, Croatia, Romania, and Latvia. ${ }^{73} \mathrm{He}$ claims the status of Estonia to be unclear. According to Podraza:

Central Europe covers the terrains situated between the river Elbe and its extension toward Istria, the eastern border of Poland and Hungary, and the southern border of Hungary and Croatia. Additionally, Central Europe encompasses three Baltic States, which have been for centuries associated with the West with regard to culture and religion, and with the East with regard to economy. ${ }^{74}$

\section{On the Nature of the Distinctiveness of Central Europe}

One of the landmark events, which determined the distinctiveness of Central Europe, was the development of a manorial-serf economy. It is believed to be the foundation for distinguishing two principal developmental lines in the evolution of European feudalism: a Western-European and a Central-European path. This developmental differentiation was finally established in the 16th century. The river Elbe became the borderline between the two developmental paths:

A rural economy, founded on large and average-size farms leased by peasants who worked on them, was established in the area west of the river Elbe. In contrast, east of Elbe, predominantly in the countries in Central-East Europe situated south of the Baltic Sea, the economic development headed toward the development of a manorial farm and production for sale. In the field of relations of production, a manorialserf economy brought about an increase of servitude of peasants (introduction of the "second serfdom") and of the scope of serfdom, in order to gain a villein service for a manorial estate. ${ }^{75}$

The serfdom of peasants was the foundation of the manorial-serf system. It manifested itself in the form of personal, economic, and judicial dependence. The personal aspect of serfdom reduced the freedom of peasants, who had to seek consent of the lord to leave their place of residence, enter marriage, or send

73 Jerzy Kłoczowski, "Europa Środkowo-Wschodnia," in: Historycy wobec problemów tożsamości narodowej i europejskiej - między nacjonalizmem a uniwersalizmem. XVIII-XX wiek (Lublin: Materiały Instytutu Europy Środkowo-Wschodniej, 1992), Vol. 1, pp. 10-11.

74 Antoni Podraza, "Europa Środkowa jako region historyczny," in: Materiaty z 17 Powszechnego Zjazdu Historyków Polskich, 15-18 września 2004, in: http://jazon.hist. uj.edu.pl/zjazd (accessed: February 2, 2018).

75 Zbigniew Wójcik, Historia powszechna XVI-XVII w. (Warszawa: PWN, 1979), p. 326. Compare also: Tomaszewski, "Europa Środkowa," p. 130. 
children to schools located outside the village. Additionally, serfs and their children had to serve at manorial estates and perform duties designated by lords. Moreover, a lord had the right to sell landless peasants.

The economic aspect of serfdom minimized the freedom to decide about cultivated land. A peasant bound by perpetual lease could be deprived of land at any time. Peasants were more effectively protected by inherited lease, which allowed passing land to own children. Finally, the last aspect of feudal serfdom - judicial dependence, included a set of legal norms, which made peasants dependent on the judicial power of the landowner. According to Jeremy Blum, the difference between serfdom and slavery was that, although a serf could have been sold and bought without land, he maintained some personal rights at all times. In contrast, a slave, despite of his economic wealth, was deprived of all rights and could have been mutilated or killed by his owner without any consequences. ${ }^{76}$

In Western Europe, the above-mentioned aspects of serfdom were separated. Different owners implemented various forms of serfdom: one owner had a judicial authority over a peasant, another - economic authority, and yet another personal authority. In contrast, in Central Europe unitary serfdom prevailed. All aspects of serfdom: personal, economic, and judicial were concentrated in the hand of one person.

The present book predominantly purports to explain the development of a manorial-serf system, which substantially influenced the historical distinctiveness of Central Europe. The following chapter will present the key concepts, which attempt to explain a developmental dualism of modern Europe.

76 Jerome Blum, “The Rise of Serfdom in Eastern Europe," American Historical Review, Vol. 62 (1957), p. 809. 



\section{On the Distinctiveness of Central Europe}

Theories developed to explain the developmental distinctiveness in Europe can be divided into three types. ${ }^{77}$ The first type of theories underlines the significance of factors external to a given society, the second type of conceptualization focuses on the importance of internal factors and the third type of explanations stresses significance of both types of factors, internal and external, to the emergence of the developmental distinctiveness of Europe. In the present overview, the theories put forward by Marian Małowist and Immanuel Wallerstein analyzed the impact of factors external to a given society. The concepts of Robert Brenner, Jerzy Topolski, and Benedykt Zientara stress the importance of internal factors. Finally, the views presented by Jeremy Blum, Daniel Chirot, Władysław Rusiński, and Jan Rutkowski represent the third, mixed type of conceptualizations emphasizing the indispensability of internal and external factors.

\section{Theories Referring to External Factors}

\subsection{The Concept of Marian Małowist}

Marian Małowist was one of the first authors who rooted his account of the developmental distinctiveness of Europe in an international context. ${ }^{78} \mathrm{He}$ argued that developmental disproportions between the East and the West derived from the fact that the West benefited from the "great achievements of the Roman civilization." On the contrary, the developmental capabilities of the East were limited by "more primitive social structures," "low level of population density," "worse

77 Jerzy Topolski puts forward another typology of theories explaining the genesis of socio-economic dualism in the development of modern Europe. He distinguishes two groups of theories. The first group includes theories, which search for common factors in the emergence of capitalism and the manorial-serf system. The second group includes theories, which treat the above phenomena individually and search for separate reasons to explain them, see: Jerzy Topolski, "Causes of Dualism in the Economic Development of Modem Europe (A Tentative New Theory)," Studia Historiae Oeconomicae, No. 3 (1969), pp. 3-4.

78 Marian Małowist, "Z problematyki dziejów gospodarczych strefy bałtyckiej we wczesnym średniowieczu," Roczniki Dziejów Społecznych i Gospodarczych, Vol. 10 (1948), pp. 81-120; Marian Małowist, Wschód a Zachód Europy w XIII-XVI w. Konfrontacja struktur społeczno-gospodarczych (Warszawa: PWN, 1973). 
geographical and climate conditions," and "migrations of nomad tribes of Turkic origin" to the terrains of Central and Eastern Europe. ${ }^{79}$

Due to the civilizational advantage of Western Europe, Western-European economy reached its peak of development as early as in the 13th century. However, the continuous development of Western Europe was put on hold by an economic crisis. A substantial increase of the level of population density exceeded limited production capabilities of the economy. This brought about malnutrition of large layers of the population, which, in turn, weakened its immunity to epidemics caused by infectious diseases. In the 14th century, famines caused by incidental climate fluctuations and epidemics reduced the population of Western Europe by around $40 \%$. A devaluation of currency was another cause of the crisis. It was brought about by a growing trade in goods under the conditions of limited resources of bullion. It caused a drastic deprecation of currency in a large number of European countries. A decrease of the value of money resulted in a drop of the real value of taxes payable to the State Treasury and a drop of the real value of peasant services paid to the nobility.

Simultaneously, in the 13th and 14th centuries, the majority of CentralEuropean countries was experiencing a phase of intensive development initiated at the turn of the 12th century, which lasted until the end of the 16th century. Central Europe experienced the most intensive development in the 14th century. German settlement with German Law was a significant stimulus for economic development. German Law, a modification of Western legal solutions adapted to the conditions of Central Europe, brought about an improvement of an economic and legal situation of the peasantry founded on it. Settlement with German Law boosted the productivity of the peasantry, which proved to be a substantial factor intensifying the economic development of Poland, Bohemia, and Hungary. The consequence of the German settlement undertaken by grand landowners was a stabilization of workforce. Previously, due to a small population density, increased compulsory service stimulated a rotation of workforce cases of escapes were common among the peasantry. To increase their income, the ruling classes in the Central-European countries had to refer to economic stimuli, not to coercion. The ruling elites in Poland, Bohemia, and Hungary were becoming aware of their backwardness in comparison to the Western countries:

[T] he previous, relatively slow pace of economic growth of Poland, Hungary and Bohemia supported the evident disproportion of political and military forces between the above-listed countries and their stronger western neighbors, and the differences in

79 Małowist, Wschód a Zachód, p. 7. 
the level of population density were significant. It was a dangerous situation for all social groups of the western countries under study. ${ }^{80}$

An additional factor, which accelerated the emerging process of colonization by grand ownership, was the political balance which had developed between Central-European countries, and which prevented them from gaining income from wars. Armed conflicts, where a victorious side would acquire looted goods and prisoners to supplement manpower, had been in fact a significant source of wealth for rulers and the nobility.

An intensification of Central-European economy contributed to the development of trade contacts with Western Europe. These contacts have existed since early Middle Ages; however, a significant increase of trade in goods took place only in the 13th century. At that time the Hanseatic League was crated and a number of towns, including Dubrovnik, Vienna, and Hamburg, developed into trade centers between Western and Central Europe. As a result, the structure of trade exchange between the two parts of Europe received a unilateral character:

[W] estern merchants, whose previous outlets have contracted and experienced severe structural transformations, perceived the developing Eastern countries as highly attractive. The number of luxury goods, let alone craft products of average sort, was growing, because local producers in Poland, Hungary, and Bohemia, not to mention Balkan countries, were unable to satisfy the demand. ${ }^{81}$

Consequently, the mechanisms of international trade and non-equivalent exchange brought about the following situation:

[A] certain type of economic relations between Eastern and Western Europe was formed as early as in the late Middle Ages. Western Europe provided its Eastern partners with finished craft products, luxury goods, and capital, and to a certain extent also people, whereas Eastern countries predominantly exported raw materials, including such significant articles as bullions and other metals. The above contributed to a diversification of economy of the then developed North-West and South-West Europe, and to an acceleration of growth of craft production and, in a sense, industrial production on those terrains. (...) On the contrary, in the East, which was economically backward due to adverse starting conditions, trade with the West contributed to the civilizational advancement and increasing wealth of local and migrant merchants and feudal lords; however, it simultaneously brought about a certain economic unilateralism. ${ }^{82}$

80 Małowist, Wschód a Zachód, p. 21.

81 Małowist, Wschód a Zachód, pp. 373-374.

82 Małowist, Wschód a Zachód, pp. 375-376. 
For this reason, the mechanisms of international trade consolidated the underdeveloped economic structure of Central-European countries. Its backwardness was a result of the late start of urban economy caused by an insufficient civilizational development of Central Europe and the civilizational advantage of the Western-European societies.

\subsection{The Concept of Immanuel Wallerstein}

In the perspective of the World-Capitalist System, the main analytic categories include a notion of the center, peripheries, and semi-peripheries connected with relationships of economic exchange. This perspective introduces a new understanding of the essence of capitalism and the category of transition from feudalism to market economy. Immanuel Wallerstein maintains that capitalism is an economic system, in which products are manufactured with an intention to be sold on a market for profit subsequently expropriated based on the law of ownership. The transition from feudalism to capitalism took place between 1450 and $1600 .{ }^{83}$ Wallerstein claims that it was a unique development, which happens only once in history. The phenomena of "proletarianization of workforce" and "commoditization of land" were the aspects of the process.

A transformation of feudalism into a global capitalistic system was a consequence of a crisis, which spread over feudal Europe between 1300 and 1450 . In the Middle Ages, the European continent comprised a number of independent political organisms, not connected politically or commercially. Presence of a number of isolated economic entities was a characteristic feature of the feudal system of production. The system had enjoyed a period of expansion and advancement in the years 1150-1300. However, in the years 1300-1450, the feudal economy had gradually exhausted its internal reserves for development. A combination of three factors brought about a crisis:

- after a thousand-years-long expropriation of economic surplus, exploitation had reached a level, at which the ruling class was no longer able to further increase exploitation of the peasantry;

83 See his trilogy: Immanuel Wallerstein, The Modern World-System. Capitalist Agriculture and the Origins of the European World-Economy in the XVIth Century (New York: Academic Press, 1974); Immanuel Wallerstein, The Modern World-System II. Mercantilism and the Consolidation of the European World-Economy, 1600-1750 (New York - London: Academic Press, 1981); Immanuel Wallerstein, The Modern World-System III. The Second Era of Great Expansion of the Capitalist World-Economy, 1730-1840 (New York - London: Academic Press, 1989). 
- the level of production reached its peak at the given state of technology;

- deterioration of climate conditions caused a decrease of fertility of soil.

Pressured by the developing crisis, the ruling classes in Europe were forced to invent a new system of expropriation of production surplus. Direct expropriation was replaced with indirect expropriation founded on the mechanism of international trade. At the international market, luxury goods were replaced with mass consumption ones.

As a result, there emerged a global capitalistic system covering North-West Europe, countries with a Mediterranean coastline, Central Europe and a number of non-European regions: New Spain, Antilles, Peru, Chile, Brazil, the Atlantic islands, and the coast of Africa.

In the 16th century, Russia, the Ottoman Empire and the Far East were out of reach of the impact of the above system. The market mechanisms divided the global economic system into center, peripheries and semi-peripheries. As a consequence, North-West Europe became the center of the system, which specialized in production requiring highly qualified contract workforce. Eastern Europe and the agricultural regions of Western Europe turned into peripheries, which specialized in the export of crops and low-processed materials. Finally, the Mediterranean coastline became semi-peripheries involved in semi-industrial production of silk, and specializing in transfer of credits and trade. European peripheries slowly developed toward capitalism by introducing the commercialization of the land market and proletarianization of workforce, however only Scandinavian countries succeeded in joining the center.

Wallerstein ponders on the question why Eastern Europe became a periphery of the system and the North-West Europe - the center. The above differentiation is more interesting in light of earlier evolution of both parts of the continent in the 13th and the 14th centuries. In this period, both parts of Europe, eastern and western, developed analogically: feudal control over the peasantry lessened and the monetary economy prevailed. The development of global economic system in the 14th and the 15th centuries brought about an increase of developmental distinctiveness in the two parts of Europe because these two regions become complementary parts of a more complex whole - world economy system:

Northwest Europe emerged as the core area of this world-economy, specializing in agricultural production of higher skill levels, which favoured (. . .) tenancy and wage labor as the modes of labor control. Eastern Europe and Western Hemisphere became peripherial areas specializing in export of grains, bullion, wood, cotton, sugar - all of 
which favored the use of slavery and coerced cash-crop labor as the modes of labor control. ${ }^{84}$

Wallerstein ponders on the question why the situation was not opposite. Why did not Western Europe transform into a periphery of the system, and Eastern Europe - the center? The above situation developed as a result of a number of factors, which exerted a decisive influence on the evolution paths of the two parts of the continent. Wallerstein investigates the impact of these factors as follows:

Thus if, at a given moment in time, because of a series of factors at a previous time, one region has a slight edge over another in terms of one key factor, and there is a conjuncture of events which make this slight edge of central importance in terms of determining social action, then the slight edge is converted into a large disparity and the advantage holds even after the conjuncture has passed. ${ }^{85}$

The particular station mentioned above was the colonial expansion of Western Europe undertaken in the 15th century. The level of acquired profit depended on the degree of introduced specialization of economy in the Western Europe - the development of industry, sea transport, etc. The introduction of specialization required a lot of attention from the Western-European societies, to the detriment of the development of agriculture. As a result, Eastern Europe transformed into a food producer and the supplier of resources and crops for Western Europe. However, as Wallerstein claims, the situation could have been opposite. Western Europe could have specialized in agricultural production for Eastern Europe. According to him, in the 15th century an unsubstantial factor determined which part of the continent gained the advantage over the other, and decided on the implementation of one of the two alternatives. Due to this unsubstantial factor, in the 16th century the small advantage of Western Europe over Eastern Europe had been growing continually to finally bring about a distinction between countries situated in the center and those belonging to the peripheries. The system of compulsory labor in Eastern Europe, as Wallerstein names the manorial-serf system, developed in response to the impact of two factors: the opportunity to achieve a significant profit on the global market of agricultural products and a relative absence of manpower, when compared to large areas of uncultivated land. ${ }^{86}$ The relatively large abundance of uncultivated farmland allowed for a

84 Immanuel Wallerstein, "The Rise and Future Demise of World Capitalist System: Concepts of Comparative Analysis," in: The Essential Wallerstein (New York: The New Press, 2000), p. 86.

85 Wallerstein, The Modern World-System, p. 98, original emphasis.

86 Wallerstein, The Modern World - System, p. 99. 
colonization of new terrains. And this, in turn, facilitated an introduction of the system of compulsory labor since, according to Wallerstein, it was easier to impose such system on the newly colonized areas, in comparison to areas with the old tradition of settlement. In his discussion of the remaining factors, which determined the course of historical development, Wallerstein lists weak condition of Eastern-European towns. While in the 13th century the difference between Eastern- and Western-European towns was insignificant, in the following centuries the distance had grown and brought about an indirect dependency of Eastern-European agriculture on the Western demand.

The approach of World-Capitalist System may provide a very useful explanation of the expansion of capitalism. However, according to the concept, the problem of the genesis of capitalism, and particularly of the differentiation of developmental paths of the countries in the center and the countries in the peripheries, is not subjected to a theoretical explanation, but merely to a historical analysis. According to such description, peripheral countries are usually treated as homogenous and internally undifferentiated objects of analysis. However, as demonstrated by Darius Žiemelis, the economic development of the Grand Duchy of Lithuania between the second half of the 16th century until the abolition of serfdom in the Russian Empire in 1861, only roughly falls under the definition of the development of the peripheral capitalism assumed by Wallerstein's model. In the first period from the mid-16th century to the mid18 th century, serfdom was just one of the many forms of feudal rent implemented mainly in the estates of the great magnates. In the Grand Duchy of Lithuania, the main source of income for property owners was not the sale of agricultural products on the internal and external market, but the profits from the lease of taverns and mills. ${ }^{87}$ Moreover, the "received funds were invested [by the estate owners] not in maximizing the held resources, but to the expansion of the usage of the social elite," 88 which, according to the author, precludes the possibility of treating a manor as an enterprise operating in the conditions of peripheral capitalism. Furthermore, the intensification of serfdom in the second half of the 18th century was not, according to Žiemelis, the main source of income in the Grand

87 Darius Žiemelis, "The Socio-Economic History of Lithuania from the 16th to the 19th Century (until 1861) from the Perspective of Economic Development Concepts," Romanian Journal for Baltic and Nordic Studies, No. 2 (2013), p. 79.

88 Darius Žiemelis, "The Problem of Application of the term second serfdom in the history of Central Eastern Europe," Romanian Journal for Baltic and Nordic Studies, No. 1 (2015), p. 136). 
Duchy of Lithuania. ${ }^{89}$ In 1795, the direction of export of agricultural products has also changed: "due to its incorporation into Russia from the end of the 18th century [Lithuania] became the agrarian periphery of the empire beginning with the 20th century. All of this 'conserved' even more the peasant production for family consumption in agriculture and determined the weak development of Lithuania's cities." 90 Then, the economy of the Grand Duchy of Lithuania was more in line with the model of peripheral development.

The World-Capitalist Economy approach, explaining the phenomenon of backwardness of peripheral countries, focuses on external rather than internal factors. There are reasonable doubts as to whether external factors are so significant. ${ }^{91}$ Topolski puts forward a critique of Wallerstein's concept with relation to Poland:

In general, in the following years [of the 17th century], the Baltic region produced annually the maximum of 100,000 tons of grain (mostly wheat), which satisfied the demand of ca. 750,000 people. When compared to the level of population density in Europe of around 104,000,000 people in the beginning of the 17th century, it accounted for an unsubstantial percentage (less then 1\%). [...] When compared to the global grain production of Western Europe, the exported amount was also insignificant. Wyczański, an author of the most comprehensive estimations of grain production in the 16th century Poland, has recently stated that the export of Polish grain in the second half of the 16th century accounted for the maximum of $2.5 \%$ of global production. ${ }^{92}$

Certainly, economic relations consolidated the underdeveloped economic structure of Central Europe. However, they did not itself determine the pivotal direction of the social evolution, the tendencies of which had manifested in the past.

89 Žiemelis, “The Problem of Application," p. 138.

90 Žiemelis, “The Problem," p. 142.

91 Compare for example with Hunt who claims that war devastations of the 16th and the 17th centuries substantially contributed to the developmental backwardness of Central Europe, see: Verl F. Hunt, "The Rise of Feudalism in Eastern Europe: A Critical Appraisal of the Wallerstein 'Word - System' Thesis," Science and Society. An Independent Journal of Marxism, Vol. 42, No. 1 (1978), pp. 43-61. Also, according to Nerijus Babinskas, the external factors (selling grain on the international market) were not decisive in introduction of second serfdom in Moldova and Wallachia at the turn of the 16th and the 17th centuries, see: Nerijus Babinskas, "Economic Challenges in Early Modern Ages and Different Responses of European Margins. Comparative Considerations Based on Historiography: The Cases of Polish-Lithuanian Commonwealth and Moldovian Principality," Romanian Journal for Baltic and Nordic Studies, Vol. 4, No. 2 (2012), pp. 57-60.

92 Jerzy Topolski, Prawda i model w historiografii (Łódź: Wyd. Łódzkie, 1982), pp. 309-310. 


\section{Theories Referring to Internal Factors}

\subsection{The Concept of Robert Brenner}

Robert Brenner put forward an alternative account of the dichotomy between developmental paths of Eastern (including Central-European countries) and Western Europe. Brenner devoted a number of papers to construct and subsequently develop a general model of feudalism with the purport to grasp the developmental differences between England and France, on the one hand, and Western and Eastern Europe, on the other. ${ }^{93}$

According to Brenner, the factor of class structure is the key category of social development. On the one hand, it encompasses organizational dependencies between direct producers and their approach to material tools used in the production process. On the other hand, a social class structure dictates ownership relations, which allow the nonworking class of owners to expropriate secondary production. Expropriation may be direct or indirect, but in the end it always depends on the factor of violence. Following from this, ownership relations determine the fundamental social division into the class of direct producers and the ruling class capable of expropriating secondary production. ${ }^{94}$

For this reason, a class structure is the basic category determining the mechanisms of social development. However, the category of class structure has taken on a number of forms within various socio-economic formations. For instance, feudalism and capitalism were two completely different social systems. Most importantly, the class of direct producers - the peasantry - had a direct, not mediated by market mechanisms, access to work tools and means of production. The peasant mode of production consisting in cultivation of land did not require intervention from lords. Moreover, the slight evolution of market relations brought about a self-sufficiency of peasant farms. As a result, in order to purchase goods the peasantry did not have to sell its products on the market. To be able to expropriate secondary production, a feudal lord had to have a political

93 Robert Brenner, "Agrarian Class Structure and Economic Development in PreIndustrial Europe," Past and Present, Vol. 70 (1976), pp. 30-75, Robert Brenner, “The Agrarian Roots of European Capitalism," Past and Present, Vol. 97 (1982), pp. 16-111; Robert Brenner, "Economic Backwardness in Eastern Europe in Light of Developments in the West," in: The Origins of Backwardness in Eastern Europe. Economics and Politics from the Middle Ages until the Early Twentieth Century, ed. Daniel Chirot. (Berkeley: University of California Press, 1985), pp. 15-51.

94 Brenner, "Agrarian Class Structure," p. 31, original emphasis. 
power over the peasantry. This way, by referring to the means of coercion, feudal lords could expropriate the production surplus. As Brenner claims:

"fusion" (to put it imprecisely) between "the economic" and "the political" was a distinguishing and a constitutive feature of the feudal class structure and system of production. This was manifested in the fact that the "economic" conditions for the reproduction of the ruling class - the income it required to carry out its life activities, including the continuing subjection of the peasantry - depended upon a system of extraction of surplus labor from the direct producers, which was characterized by extra-economic ("political") compulsion. ${ }^{95}$

The above structural distinctiveness of the feudal system dictated feudal rules of reproduction, which determined the dynamics of the system. Brenner emphasizes that both, the lords and the peasants, had access to the means that guaranteed their survival. Additionally, the absence of market brought about a situation, in which economic entities were not forced to increase production to maximum.

Brenner discusses two sources of the dynamics of feudalism: colonization of new terrains and a so-called political accumulation. Colonization was a typical form of development of feudalism. The increase of the level of population density stimulated the process of land-use of new terrains. As a result, the economic situation of the peasantry improved and feudal lords became capable of conducing a mostly conflict-free expropriation of the production surplus brought forth by the class of peasants. However, the boundaries for colonization were set by the limited amount of land available for cultivation with the medieval production technique. After the land resources had been exhausted, political accumulation became the second source of dynamics of the feudal system. It consisted in an expansion of the private or state military-clerical apparatus purported to redistribute income or increase exploitation of the peasantry using imposed taxes. Additionally, Brenner studies mutual relations between two sources of the dynamics of the feudal formation. Political accumulation was the basic mechanism of the evolution of the feudal system on the central terrains of the European feudal society. There emerged centralized state monarchies and, subsequently, absolutist monarchies. Differently, on the peripheral terrains of European feudalism - in Poland, Bohemia, and Hungary, colonization dominated over accumulation. As a result, the ruling classes of the above-listed societies did not have to expand their centralized state apparatus. ${ }^{96}$

95 Brenner, “The Agrarian Roots," p. 28.

96 Brenner, “The Agrarian Roots," pp. 27-30. 
The above-described internal tendencies embedded in the developmental mechanisms of feudalism brought the formation to an internal crisis. Due to absence of market mechanisms, an intensification of production was not required. Production grew in an extensive way - the evolution of the population led to land use of new terrains. However, a constant increase of the level of population density at the unchanging production technique brought about relative overpopulation and shrinkage of the area of cultivated land. In the middle of the 14th century, as a result of famine and the plague epidemic, the European population was significantly reduced. The crisis of feudalism had different consequences for various areas of Europe, depending on the ability of individual social classes to push across their interests. I will now discuss Brenner's explanation of the developmental differences between Eastern and Western Europe.

In the 13th and the 14th centuries, the terrains of Eastern Europe were subject to colonization with German Law. By organizing German colonization, feudal lords attempted to expropriate production surplus. Since the 15th century, after the settlement stimulated by the migration of Western-European (particularly German) peasantry decreased, North-East Europe has experienced a rise of slavery. An enforcement of serfdom was purported to solve the problems brought about by a shortage of workforce. The problems appeared when the level of Western-European population density decreased and it became impossible to bring settlers from this area. In Brenner's words, the decreasing population, and the growing possibility to purchase luxury goods and sell grain on the internal market brought about an increase of the control of the feudal lords over the peasantry. As a result of the above processes, the feudal lords introduced a limitation of free movement and an increase of the burdens of serfdom. Brenner ponders on why if a reorganization of class relations succeeded in the East, similar simultaneous tendencies proved unsuccessful in the West. According to him, absence of successful peasant revolutions allowed the Eastern-European nobility to increase the scope of their control over the peasantry. And on the contrary, the attempts to introduce serfdom in Western Europe were unsuccessful, due to effective resistance of the peasantry. According to Brenner, it was a consequence of varied class relations on the East and the West of Europe, which resulted from different models of evolution implemented in the two parts of the continent.

On the East, the nobility organized and controlled the process of settlement, and granted privileges and economic rights to the peasantry. On the West, on the contrary, the colonization of new terrains was in general a bottom-up initiative of the peasantry, only top-down controlled by the feudal lords. From this source, the freedom of the Western-European peasantry was a result of a long-lasting class struggle, which led to the creation of common peasant institutions. On the 
East, the same scope of freedom was granted in a top-down way, as a result of German settlement organized by the feudal lords. Therefore, when it became impossible to bring settlers due to the population crisis on the West of Europe, the nobility introduced a more rigorous system of management of the peasantry. ${ }^{97}$ Eastern-European peasantry - less organized and with no tradition of class resistance, was unable to effectively oppose the policy of the feudal class.

Introduction of serfdom exerted significant influence on the socio-economic evolution of Eastern Europe. Most importantly, the economic system based on compulsory labor of the peasantry brought about a technological stagnation in agriculture. Additionally, a decline of income of the peasants brought about a decrease of demand of this social group for craft goods produced in towns. Limitation of the mobility of the peasantry deprived towns from access to cheap workforce. The above two factors combined with anti-town policy of the nobility led to a degradation of towns and a long-lasting socio-economic backwardness of Eastern Europe.

According to Brenner, the principal factor differentiating the development of Eastern and Western Europe resulted from the character of class resistance of the peasantry: effective in Western and ineffective in Eastern Europe. The above difference was a consequence of the impact of institutional and consciousnessrelated factors: Western-European peasantry, in contrast to the Eastern peasantry, was better organized and had longer traditions of class struggle. However, within the presented conceptual model, the category of effectiveness or ineffectiveness of class struggle is highly unclear. It may be understood in two ways: an effective resistance of the peasantry directly leads to a transformation of a class structure of a society or brings about an improvement of the financial situation of the peasantry within a given class structure. Nonetheless, if we adopt the first understanding of the notion, then the class struggle of the peasantry in both, Western and Eastern Europe, was ineffective, since it did not bring about a transformation of the structure of ownership. The second understanding of the category must refer to a social context. If the balance between social classes of a feudal society: rulers, burghers, and the nobility, prevailed, then resistance of the peasantry forced the feudal class to grant concessions and led to an improvement of the economic situation of the peasantry. The above-described social conditions were present in the Western Europe. This, however, puts an emphasis

97 Brenner, “Agrarian Class Structure," pp. 53-60; Brenner, “The Agrarian Roots," pp. 69-76, Brenner, "Economic Backwardness," pp. 42-45. 
on the impact of the urban sphere, which Brenner deprives of any significance to the process of European distinctiveness.

Another unclear point in Brenner's concept is the link between the end of the settlement processes in the Eastern Europe, which ended in the 2nd half of the 14th century, and the introduction of serfdom. According to his theory, the shortage of manpower was the only factor, which influenced the evolution of the manorialserf system. However, a manorial-serf economy emerged in Central Europe over 150 years after the plague epidemic and the ending of the settlement processes (symbolically, a manorial-serf economy in Poland was initiated with the decisions of the Piotrków Sejm from 1496 and the Bydgoszcz-Toruń Statutes from 1520; in Hungary with the completion of the Tripartitum in 1514 and in Bohemia with land statutes in 1627/28). Brenner's reference to the Teutonic State as an example, which already at the beginning of the 15th century issued regulations targeting the desertion of the peasantry, is unconvincing. The Teutonic State had a different social structure then the rest of the countries in the region. In the Teutonic society, there was a significant concentration of power and ownership (and the means of spiritual production, too ${ }^{98}$ in the hands of a single social class able to implement the means of state coercion to regulate work relations. In Central-European societies, social conditions were different, since the political power was independent from the nobility and burghers balanced the influence of the nobility. Over 150 years had to pass before the nobility in the Central-European countries became capable of subjugating the state to its needs and of limiting the rights of burghers. The introduction of serfdom is a reaction to the deficiency of workforce; however, this holds true only in a situation when the class of owners gains dominance in the state and limits the influence of the urban labor market. Otherwise, the only strategy available to owners is granting concessions. The above conclusion becomes clear only if one adopts a different theoretical perspective, in which the state is not only a servant of ownership but also an institution hiding a social class with a separate social interest than the owners.

\subsection{The Concept of Jerzy Topolski}

Topolski discusses a problem of the development of the feudal system and its differentiation in a series of books and papers published during his entire academic carrier. ${ }^{99}$ In the area covered by the Carolingian Empire, the feudal

98 See chapter: “The Basic Ideas of non-Marxian Historical Materialism”).

99 Jerzy Topolski, "Causes of Dualism in the Economic Development of Modem Europe (A Tentative New Theory)," Studia Historiae Oeconomicae, No. 3 (1968), pp. 3-12, Jerzy 
system emerged as a result of the dissolution of slavery and the introduction of the social institution of Germanic tribal communities. Differently, in the East - in Germany, Poland, Bohemia, Slovakia, Hungary, Ukraine, and Belarus the emergence of feudalism was a consequence of the dissolution of agrarian communities, the gradual development of private property and the rise of the nobility. In this part of Europe, the state was the factor, which stimulated feudal transformations, since it supported the process of development of the class of owners. In the period of early-feudal monarchy, the institution of state set up its own economic sector where the peasantry, which was grouped in special servicing villages, performed specialized services and produced the needed goods. The ruler identified with the state and treated the entire state, including the land, as his patrimonial property. However, subsequently, the development of the nobility brought about dissolution of the primal system of the state economy. State authorities granted privileges and immunity concessions, which led to the development of a feudal layer of landowners, who were solely interested in management. As a result, the processes of increasing the significance of the nobility brought about a collapse of the institution of state. While in the 10th and the 11th centuries the state constituted the principal factor, which stimulated the economy, in the 13th and the 14th centuries the feudal lords replaced it. This class organized grubbing-up forests, set up new villages and towns, brought in settlers. The action of grand ownership created favorable conditions for the development of peasant farms, which in the 14th and the 15th centuries constituted the primary factor of economic growth.

Differently, until the second half of the 13th century Western Europe was experiencing a period of rapid economic development, which was put to an abrupt halt in the middle of the 13th century. The economic stagnation was caused

Topolski, "The Manorial - Serf Economy in Central and Eastern Europe in the 16th and 17th Centuries," Agricultural History, Vol. 3, No. 48 (1974), pp. 347-348, Jerzy Topolski, Prawda i model w historiografii (Łódź: Wyd. Łódzkie, 1982), Jerzy Topolski, Narodziny kapitalizmu w Europie XIV-XVII wieku (Warszawa: PWN, 1987), Jerzy Topolski, "The Development and the Crisis of the Manorial System Based on Serf Labour: A Tentative Explanation," in: Entrepreneurship and the Transformation of the Economy (10th-20th Centuries). Essays in Honour of Herman Von der Wee, eds. Paul Klep, Eddy Van Cauwenberghe (Leuven: Leuven University Press, 1994), pp. 135147, Jerzy Topolski, Polska w czasach nowożytnych Od środkowoeuropejskiej potęgi do utraty niepodległości (1501-1795) (Poznań: Wyd. UAM, 1994), pp. 19-47, and posthumously: Jerzy Topolski, Przełom gospodarczy w Polsce XVI wieku i jego następstwa (Poznań: Wydawnictwo Poznańskie, 1998). 
by the discrepancy between the rapidly growing level of population density and the production capabilities of medieval agriculture. The above phenomenon brought about the fragmentation of farmland, increase of prices of agricultural products, decrease of industrial prices, and drop of agricultural productivity. A further increase of the level of population density above the production capabilities of the economy led to food crises, and a decreased immunity of the population against epidemics and diseases. The relationship between the population and the production potential of the economy begun to stabilize around 1369 after a series of famine and epidemics, which drastically reduced the population of Western Europe.

The above-described disruptions of the economic evolution brought about an emergence of a particular tendency in the entire Europe, namely a drop of income of the European nobility. The reasons for the reduction of income were various but, according to Jerzy Topolski, they were in general associated with the consequences of the development of the money-goods economy:

[D]ifferent social classes and social layers had differently benefited from the evolution of this economy. At first, the nobility had also profited. However, their benefits soon proved to be apparent because they were not connected with direct production activity, but with a certain reorganization of the system of expropriation of feudal rent. By implicating an increase of money-goods relations, this reorganization consisted, as we know, in a shift from various types of serfdom and compulsory serf labor (pańszczyzna), and various tributes in kind to paid rent. ${ }^{100}$

The income of the nobility decreased due to the resistance of the peasantry, which precluded a further increase of villein service. Moreover, the processes of depreciation and devaluation of currency constituted a permanent feature of the medieval economy. This brought about a decrease of real (but not necessarily nominal) income of the nobility. Additionally, at the turn of the 14th and the 15 th centuries, the wages of paid workers in agriculture increased. Moreover, the expansion of burghers posed a risk for the nobility. At that time, burghers in Italy, Spain, France, Germany, and Poland took over a number of the nobility's estates. The economic expansion of the Church brought about similar consequences. Due to donations, grants and legacies made in testaments, many land estates were transferred into the possession of church institutions. Additionally, at that time there was much devastation connected with wars and defeats. Topolski also mentions a biological factor - an increase of the level of population of the nobility caused a growing fragmentation of demesne of this social group.

100 Topolski, Narodziny kapitalizmu, p. 68. 
The reduction of income forced the nobility to launch a counter-action. Jerzy Topolski lists four principal ways, in which the nobility enlarged its income: by increasing the income expropriated form the peasantry, by seizing part of the income of burghers, by changing the division of profit inside the feudal class and by undertaking an economic activity. ${ }^{101}$ Attempts to increase exploitation of the peasantry brought about a series of revolts and revolutions, which had swept throughout Europe from the 2nd half of the 14th century until the beginning of the 16th century. Moreover, burghers successfully hindered the acquisition of their income. The only way to seize it was via relationships and family ties. A more effective method of preventing a decrease of income of the nobility was to change of the method of distribution within the feudal class. In the current period, the nobility, supported by the state, was seizing church assets.

Nonetheless, in a long-term perspective, the economic activity of the nobility was the only successful method of increasing income or at least preventing a reduction of income. It took on various forms, depending on local conditions, i.e. the English nobility took up sheep farming, in Bohemia the nobility set up ponds and engaged in fish farming, and in Poland this social class took up grain production. In Western Europe, the strength of burghers and the existing capitalistic system directed the economic activity of the nobility toward moneygoods economy using paid workforce.

The socio-economic conditions of Central Europe gave grounds for the diffusion of a manorial-serf economy. According to Topolski, it was a different manifestation of the same economic process:

The nobility took up various forms of economic activity, particularly if we compare the situation in the countries west and east of the river Elbe. However, all of these activities were a response to the common situation of the process of decreasing income. In this sense, there is a new explanation of the emergence of a manorial-serf economy in Poland and in other countries. It is not a manifestation of the developmental distinctiveness of Europe, west and east of the river Elbe, but predominantly a consequence of the common processes of activation born on the common ground. Both the English enclosure and the development of villein manors (folwarki pańszczyźniane) belong to the same larger process. The forms of economic activity of the nobility predominantly depended on the natural conditions of a given terrain (i.e. location, climate, etc., level of manpower, which was associated with the level of dissolution of slavery in the end of the Middle Ages) and with the character of the market available to the production connected with the increased economic activity of the nobility. ${ }^{102}$

101 Topolski, Narodziny kapitalizmu, p. 72.

102 Topolski, Narodziny kapitalizmu, p. 182. 
Topolski provides a more detailed description of factors, which determined the forms of economic activity of the nobility. He divides them into three groups associated with: (1) relationship between land and workforce; (2) potential to sell crops; (3) natural conditions. On areas where the existence of the urban market dictated high wages for workers and where the peasantry enjoyed personal freedom, the nobility chose forms of production not requiring a lot of manpower (e.g. sheep grazing in England). Differently, in Poland and other CentralEuropean countries where serfdom prevailed and towns were underdeveloped, the nobility could introduce more labor-intensive forms of production (e.g. the production of grain in Poland). Another group of factors was associated with the possibility to sell crops. For instance, because of the weak internal urban market, the Polish nobility could only sell its products to the West. Polish producers specialized in production of grain and other agricultural products to answer the demand of Western Europe on these goods. Finally, the third group of climate and geographical factors exerted additional influence on the economic decisions of the nobility. Topolski lists location, climate, class of soil, etc. A combination of factors belonging to the above-described three groups brought about the development of a number of types of villein manors specializing in production of grain, cattle, sheep, fish and wine.

Topolski distinguishes between two stages of re-feudalization of economic relations in Central Europe. The first stage, lasting from the end of the 15th century until the first decades of the 17th century, was characterized by:

development and spread of a manorial-serf economy and the so-called second serfdom. During the period the economic structure underwent a significant transformation. Peasant farms [...] lost their independence and became a mere part of a whole, in which a manorial estate had a domineering position. This position was associated with the non-economic (political) power of the nobility. ${ }^{103}$

The second stage of re-feudalization was associated with the influence of the manorial system on the economic life. Manorial-serf economy put the process of development of capitalistic elements in the economic structure of Central Europe to a long halt. In the social sphere, the process of concentration of feudal ownership and aristocracization of the nobility accompanied it in the Central Europe in the 15th and the 18th centuries. It was not until the agrarian reforms of the 19th century, which granted landownership to the peasantry and abolished their dependency from landowners, that the development of a capitalistic economy became possible.

103 Topolski, Prawda i model, p. 320. 
The key idea of Topolski's concept is his statement on the reduction of income of the nobility. This decrease led to a counteraction of this social class, which in consequence brought about a dichotomy in the development of Europe and a rise of the manorial-serf system in Central Europe, among other things. However, Topolski's thesis has an empirical and not a theoretical character. It does not derive from a more general model of feudalism. Therefore, it is not clear whether the decrease of income of the nobility - the principal factor, which brought about capitalistic transformations in the West - resulted from internal developmental mechanisms of the feudal formation, or was caused by pure coincidence. Topolski does investigate the phenomenon, however he offers a historical analysis, not a theoretical one. If the drop of income of the nobility was caused by coincidental factors, then it is necessary to pose the following question: what would have happened if the reduction of wealth of the nobility had not taken place at all? Would there have been no capitalism and no developmental diversification in Europe? Without embedding the phenomena described by Topolski in a more general theory, it is difficult to provide a reasonably supported answer to the above question.

\subsection{The Concept of Benedykt Zientara}

Benedykt Zientara claims that, as distinct from the situation in Western Europe, the agrarian relations east of the river Elbe were characterized by the concentration of all aspects of feudal sovereignty over the peasantry in few hands. ${ }^{104}$ As a result, feudal lords were able to enforce service of unpaid labor on the peasantry. A noble's demesne (folwark szlachecki), instead of an independent peasant farm, was the basic production unit. According to Zientara, the underdevelopment of the urban sphere was decisive in the rise of a manorial-serf system:

[T] owns were weak economically and politically divided, and as such unable of uniting around common interests and of becoming a factor capable of balancing the influence of feudal lords to a certain degree. Therefore, absolutist monarchy could not arise in the Central-European countries [...] Instead, there developed a "democracy of the nobility" with more or less concealed superiority of the great magnates - the owners of latifundia, who were gradually pushing towns to the margins of political life (in Poland earlier than in other countries). ${ }^{105}$

104 Benedykt Zientara, “Z zagadnień spornych tzw. 'wtórnego poddaństwa’ w Europie środkowej,” Przegląd Historyczny, Vol. 1, No. 47 (1956), pp. 3-4.

105 Zientara, “Z zagadnień spornych," p. 44. 
The underdevelopment of towns allowed the nobility and magnates to dominate state power, using the system of the democracy of the nobility, and to introduce the so-called "second serfdom." Zientara stresses the significance of the internal factors responsible for the social development of Central Europe. ${ }^{106}$ Zientara concludes his reflections with the opinion that "the structure of class power [...] based on economic premises" exerted a decisive influence on the development of a manorial-serf economy:

Economic and political weakness of towns, the association of some of them with the nobility's economic interests, the relatively weak development of the internal market all of these factors allowed feudal lords to gain a much stronger social position than they had in Western Europe and prevented the development of absolutist monarchies. ${ }^{107}$

\section{Combined Theories}

\subsection{The Concept of Daniel Chirot}

When analyzing the genesis of manorial-serf economy in Central Europe, Daniel Chirot states that this type of production - based on compulsory labor performed by farm workers, where the effects of production are sold on the market - differs from classic serfdom in feudalism and from the system of slavery. ${ }^{108}$ In these economic systems the greater part of products manufactured by direct producers was intended for consumption by owners, and not for the market.

The system of compulsory labor came to existence as a consequence of the impact of four factors. The first factor was the presence of the class of grand landowners. This social category did not descend from the class of small landowners, but mostly stemmed from the war aristocracy or the ruling elite, which first conquered and later economically subordinated the native peasantry. Following from this, the presence of the layer of grand landowners was one of the causative factors of the system of compulsory labor in Eastern Europe, Asia, and Latin America. The existence of this social category brought about economic polarization of the society: concentration of land ownership in the hands of a small minority and emergence of landless layer of farm workers.

106 Compare with Tymieniecki's argument stressing the importance of internal factors, see: Kazimierz Tymieniecki, "W sprawie zaostrzonego poddaństwa w Polsce i Europie Środkowej," Roczniki Historyczne, Vol. 24 (1958), pp. 283-328.

107 Zientara, “Z zagadnień spornych,” p. 46.

108 Daniel Chirot, “The Growth of the Market and Service Labour Systems in Agriculture," The Journal of Social History, No. 2 (1975), pp. 67-80. 
A shortage of manpower was the second factor which enabled the development of the system of compulsory labor. If there is surplus manpower in comparison to the amount of farmed land cultivated with a given level of technique, then "labor will compete for work on the large estates and laborers will be free to leave since landlords will always be able to find new labor. A free tenancy system or a wage labor system (generally with cheap wages will prevail."109

Differently, if there is a shortage of workforce in comparison to cultivated land, than "laborers will tend to migrate to areas where less of their products is taken from them, and landlords will be hard put to find easily exploitable labor. In such situation, if landlords control the political process, they will tend to reduce labor mobility by law and force." 110

An agricultural system based on cultivation of only one species of plants was the third factor enhancing the development of the system of compulsory labor. Agriculture based on monoculture brought about demand for unqualified workforce, which could have been provided only via the system of compulsory labor. Mechanization and technological advancement associated with a more diverse system of crops created demand for qualified workers.

Finally, the last factor was the presence of a market, internal or external, which created demand for production manufactured under the system of compulsory labor. Therefore, a reorganization of the production mode depended on the impact of market forces, among other factors.

According to Chirot, Poland was one of the classic examples of an economic transformation. In the 16th century, trade contacts between Poland and Western countries have developed significantly. Demand for grain, production of which did not require an advanced technology, was one of the conditions for reorganization of the mode of agricultural production. Presence of the class of owners, which controlled political life, and the state of deficiency of workforce allowed for a reorganization of the system of production into a manorial-serf economy. This system prevailed until the middle of the 19th century when a growing level of the population density and technological advancement led to the substitution of the analyzed mode of production in favor of a capitalist economy. Analogical systems of production came to existence in Latin America, Asia and Africa. According to Chirot,

[t]he combination of markets for agricultural products, labor shortages and concentration of landowning into relatively few hands produced servile labor systems in other

109 Chirot, “The Growth of the Market," p. 68.

110 Chirot, "The Growth of the Market," p. 68. 
parts of the world as well as in Eastern Europe. Thus, the key reason for the growth of slavery in Americas was the acute labor shortage on the European owned sugar, cotton, and tobacco plantations. ${ }^{11}$

Chirot ponders on the question of the status of the system of compulsory labor. He perceives it as a system of production different from the system of slavery, feudalism or capitalism:

Agrarian servile labor systems oriented to the market have enough similarities that they can be viewed collectively as a distinct mode of production with its own economic and social characteristics. This mode of production does not fit into classical Marxist modes of production (communal, city, Asiatic, feudal, capitalist, socialist) any more than it fits into traditional stereotypes of "peasant economies" characterized by subsistence economies and more or less pure "folk cultures." 112

The above-presented model displays a connection between Eastern Europe and other underdeveloped countries. What is questionable in Chirot's concept is the decisive role attributed to grand ownership. In Poland, and more broadly in Central Europe, grand ownership did not descend from war aristocracy, which conquered the native population. Moreover, the area occupied by a noble's demesne was not large - ca. 60-80 ha. It follows that the concentration of ownership and the rise of magnates was not so much a cause as a consequence of the development of the manorial-serf system.

\subsection{The Concept of Władysław Rusiński}

Władysław Rusiński claims that villein manors had already existed in the Middle Ages. ${ }^{113}$ A noble's demesne descended from the feudal lords' own farm (praedium, allodium), which was intended for subsistence farming. During settlement with German Law, these farms begun to employ paid labor. Gradually, as the absorbency of the internal market and the development of towns grew, farm

111 Chirot, "The Growth of the Market," p. 69.

112 Chirot, “The Growth of the Market”, pp. 75-76.

113 Władysław Rusiński, "Drogi rozwojowe folwarku pańszczyźnianego," Przegląd Historyczny, Vol. 47 (1958), pp. 617-655; Władysław Rusiński, “'Pustki’ - problem agrarny feudalnej Europy," Roczniki Dziejów Społecznych i Gospodarczych, Vol. 23 (1961), pp. 9-50; Władysław Rusiński, Rozwój gospodarczy ziem polskich w zarysie (Warszawa: Książka i Wiedza, 1969); Władysław Rusiński, "Rugi chłopskie w Europie środkowo-wschodniej w XVI-XVI1I w.”, Roczniki Dziejów Społecznych i Gospodarczych, Vol. 38 (1977), pp. 1-47. 
production shifted to commercial production. The internal market was rather limited, hence

further expansion of production is possible with expansion of foreign outlets. Profitability of commodity production dictates entrance into these markets. The peasantry is forced to work more, in order to acquire profit. As a result, commercial production for expanded markets leads to the so-called second serfdom. The process is slow and gradual; praedia gradually specialize, focus on grain production and transform into villein manors. ${ }^{114}$

The acreage of villein manors was enlarged at the expense of fallow, uncultivated lands. Another way to expand a manor was through acquiring a better land farmed by the peasantry in exchange for lower-quality land and buying out village headmen' manors (folwarki soltysie). Two factors brought about the rise and development of manorial-serf economy: political superiority of the nobility and the increased demand for agricultural products of Western Europe. According to Rusiński, the development of the nobleman's demesne would be impossible without a broad outlet. The internal market, even in the period of the most intense boom of towns, was restricted within certain limits; therefore, the development of a manor depended on sale of grain in Western-European countries. The evolution of industry, the rise of population employed in nonagricultural sectors, the growing prosperity, and the general growth of the population density, particularly in the years 1450-1600, brought about an increased demand for grain in Western-European countries. During this period, WesternEuropean agriculture fell into a technological stagnation. According to Rusiński,

[t]he demand for Polish grain and in part for other products offered by the agricultural and livestock farming economy (meat, fur, etc.) in Western Europe is possibly one of the most significant reasons for the development of a manorial-serf economy. Other reasons [...] had a secondary character (internal market, fallow land, access to the sea). ${ }^{115}$

There was also another factor which brought about the rise and development of the manorial-serf economy: "the nobility in Eastern-European countries exerted a decisive influence on the state affairs and a free hand with the peasantry."116

The above is associated with a question posed by Rusiński: Why the increase of demand for grain was not satisfied with agriculture in England or the Netherlands, countries where the developments could have unfolded in a similar way? He answers in the following way:

114 Rusiński, “Drogi rozwojowe," pp. 623-624.

115 Rusiński, Rozwój gospodarczy, p. 74.

116 Rusiński, Rozwój gospodarczy, p. 646. 
[T] he significant increase of productive forces in the industry, the improved standard of living and the global increase of population caused the indigenous agricultural production to lag behind the evolution of industry; due to higher rate of income in the industry, people moved from rural areas to towns, agricultural land turned into pastures and became a resource base for textile industry - there was no material stimulus for the development of agriculture, since imported agricultural products were less expensive. ${ }^{117}$

Imported products were less expensive because the nobility was able to increase the extent of serfdom, using vassal relationships gained through political superiority. On account of unpaid work of the peasantry, the export of grain to the West was cost-effective. According to Rusiński, the fundamental factors, which brought about the distinctiveness of Central Europe, were both intersocial and external. Political dominance of the nobility in the state was essential to the process of reintroduction of serfdom and the expansion of villein manors. It was accompanied by a demand for grain of the Western-European countries, which consolidated the backward structure of the Central-European countries.

\subsection{The Concept of Jeremy Blum}

When presenting his account of the history of serfdom in Western and Eastern Europe, Jeremy Blum points out that the disappearance or emergence of serfdom depended on the level of state interference into economic life:

A sign of the waning of serfdom was when the central power began to intrude itself between lord and serf, chipping away at the formers' legal and administrative powers and establishing norms for the obligations he could demand of his peasants. Conversely, the withdrawal of the sovereign from interference in the lord-peasant relation doomed free peasantry to serfdom. ${ }^{118}$

At the beginning of the 12th century, the greater part of peasants in Western Europe were serfs. In the 13th century, a substantial part of rural population enjoyed freedom, and at the dawn of the 16th century its majority was free. The process of liberation of Western-European peasantry took place in various economic conditions: in the period of prosperity and economic boom (the 12th and the 13th centuries) or stagnation and economic collapse (the 14th and the 15th centuries). In Eastern Europe, in the period preceding settlement with on German Law, the peasantry was losing the remnants of its freedom and was becoming more dependent on feudal lords. However, German settlement reversed this trend because:

117 Rusiński, Rozwój gospodarczy, p. 642.

118 Blum, “The Rise of Serfdom," p. 809. 
The sovereigns and seigneurs of the countries to which the German colonists migrated were eager for the new settlers to come, not only because they would increase the population but also because the technical skill of the Germans, gained from the experience with the more experienced with the more advanced state of economic development of the West, was superior to that of native population. That meant there would be greater yields from the land and thus increased revenues for the princes and the seigneurs and the establishment of new towns and the growth of the old ones would be promoted. The colonists for their part, could be persuaded to come only if they received assurances that they would be rid of princely and seigneurial burdens that weighed upon them at home and that they would get more land for themselves, under better terms. ${ }^{119}$

These inducements, combined with the pressure of growing population west of the Elbe, persuaded great number of Germans to seek new homes in the broad eastern reaches of the Baltic plain, and in Bohemia and Hungary. The native population of these regions was small and little of the soil was tilled, and that poorly, so that there was plenty of room for newcomers. ${ }^{120}$

Concessions granted to settlers were being gradually extended to the local population. As a result, in the 13th and the 14th centuries the peasantry of eastern Germany, Latvia, Bohemia, Silesia, Poland, part of Lithuania, and Hungary enjoyed more freedom than the substantial majority of the peasantry in these countries had enjoyed in the previous centuries and the centuries that followed after the period of colonization.

In the 13th and the 14th centuries, both in the East and the West of Europe, the situation of the peasantry was successfully improving. However, in the second half of the 14th century and particularly in the 15th century, a process of differentiation in the situation of this social class in both parts of Europe took place. While in the Western Europe the living conditions of the peasant class continued to improve, in the Eastern Europe the social conditions of the peasant class begun to gradually deteriorate. This resulted from a socio-economic crisis, which affected both parts of Europe in the 14th century. Eastern-European nobility attempted to take measures to protect itself against degradation. Some of the actions undertaken by this social group were similar to the actions undertaken by its western counterpart: setting maximal wages for paid farm workers and maximal prices on craft products, etc. However, Eastern-European nobility took additional measures, which did not have a reflection in the behavior of the Western-European nobility and were, in fact, significantly dissimilar. Instead of:

119 Blum, “The Rise of Serfdom,” p. 814.

120 Blum, “The Rise of Serfdom,” p. 816. 
reducing obligations as was the general practice in the West where the lords tried to hold their peasants and attract new ones by asking less of them, seigneurs in Bohemia, Silesia, Poland, Brandenburg, Prussia and Lithuania imposed new and heavier obligations, notably in the form of labor dues and cash payments. ${ }^{121}$

Between the end of the 15th century and the dawn of the 16th century, the greater part of the peasantry living between the rivers Elbe and Volga was once more turned into serfs. Blum ponders on the question why, although the Eastern- and Western-European peasantry had the same starting point, namely an economic collapse and stagnation of the 14th and the 15th centuries, they met so different fates. He lists four factors, which influenced the development of Eastern Europe: increased political power of the nobility in all countries of the region, increased legal power of the nobility over the peasantry, high demand for grain, and weak condition of towns and burghers.

According to Blum, the key factor in the development of serfdom in Eastern Europe was the downfall of the authority of central power brought about by wars, dynastic conflicts, etc., because:

The growth of the political influence of the nobles was of critical importance for the ultimate appearance of serfdom in Eastern Europe. It gave them the power to make successful demand of their sovereigns for a freer hands in dealing with their peasants. As a consequence, there was a progressive withdrawal of the state from the lord-peasant relationship in the course of the fifteenth and sixteenth centuries. This left the way open for the seigneurs to solve labor problems raised by the depression of the fifteenth and the prosperity of the sixteenth centuries by gradually converting their erstwhile free tenants into serfs. ${ }^{122}$

The second factor, directly associated with the first one, was a rise of the administrative and legal power of lords over peasants. Owing to this, a typical nobleman could, without the approval of the state, set obligations of the rural population as he pleased. During the heyday of serfdom, a lord or his proxy acted as a judge, a policeman, a prison warden, and a tax collector and even selected a parish priest. In fact, a peasant was a vassal of a feudal lord, rather than of a king.

The third factor listed by Blum, which decisively influenced the emergence of the developmental distinctiveness of Eastern Europe, was the increase of demand for grain in Western Europe. This favorable economic situation forced the nobility to reorganize farmsteads and accelerated a transformation of the form of feudal rent - from quitrent to socage. The fourth factor, which complemented

121 Blum, “The Rise of Serfdom,” p. 820.

122 Blum, “The Rise of Serfdom,” p. 823. 
the three above-described circumstances, was the underdevelopment of EasternEuropean towns. The weak condition of towns was caused by external factors, such as a collapse of the Hanseatic League, the competition with English and Dutch merchants, and internal factors, such as, most significantly, an anti-urban policy of the Polish and Bohemian nobility. The underdevelopment of EasternEuropean towns was among the most significant factors because:

the experience of Western Europe suggests that the enserfment of the peasantry and its corollary, the economic and political supremacy of the landed nobility, might have been avoided if the burghers of the East had been as powerful as their opposite numbers in the Western Europe. ${ }^{123}$

In Blum's conceptual framework the factor of the weak condition of towns allowed the nobility to gain political supremacy in particular Eastern-European societies, which, in turn, was essential for the rise and subsequent development of serfdom:

it seems to me that the most important reason for this divergence in the evolution of the lord-peasant relation in the two regions lay in their differences in political evolution. In the struggle for domination of the state, the nobility of the East won out over the princes and the town $[\ldots]$ As a result, the Eastern nobility, in pursuit of what it conceived to be its own best interests, was able to establish economic and social control over the peasantry and to dominate over the townsmen. ${ }^{124}$

\subsection{The Concept of Jan Rutkowski}

Jan Rutkowski was one of the first scholars to put forward an explanation of developmental dualism of Modern Europe ${ }^{125}$ Rutkowski claims that:

To answer the question concerning the genesis of dualism in the agrarian development of Europe in the dawn of the Middle Ages, one has to set it against a broad comparative background. This way, factors influencing economic development can be divided into principal, which presence was the necessary condition for the expansion of a manorialserf economy, and secondary, which accelerated the process, but did not bring about an overturn in the agricultural system by themselves, without the impact of principal factors. ${ }^{126}$

123 Blum, "The Rise of Serfdom," p. 833.

124 Blum, "The Rise of Serfdom," p. 836.

125 Jan Rutkowski, Historia gospodarcza Polski (do 1864 r.) (Warszawa: PWN, 1953), Jan Rutkowski, Studia z dziejów wsi polskiej w XVI-XVIII w. (Warszawa: PWN, 1956); Jan Rutkowski, Wieś europejska późnego feudalizmu (Warszawa: PWN, 1986); see also: Jerzy Topolski, Jan Rutkowski (1886-1949). O nowy model historii (Warszawa: PWN, 1986).

126 Rutkowski, Historia gospodarcza, pp. 91-92; Rutkowski, Wieś europejska, p. 219. 
According to Rutkowski, the system of rent prevailed in the greater part of European countries until the 14th century. It was not until the 15th century and, more particularly, the 16th century, that the manorial-serf system begun to popularize in Poland and its neighboring countries, including northeast Germany, Denmark, Bohemia, Hungary, Romania and the Baltic countries, as far as the Gulf of Finland. Rutkowski lists two principal factors contributing to the process: the ease of selling agricultural products and the serfdom of the peasantry. ${ }^{127}$

High demand for grain was a necessary condition for emergence of the manorial economy specialized in providing products for a mass market. The demand for grain developed in Western Europe at the turn of the 15th century, as a result of the rise of urban economy in the West. However, this factor is not the only driving force behind the emergence of the manorial economy. The second factor was the existence of the serfdom of peasants exacerbated to a certain level, which enabled a transformation of the agricultural system in the European countries under study. The system of serfdom allowed the nobility to decrease the costs of agricultural production. Employment of unpaid peasants-serfs, who supported themselves with their own farms, exerted a decisive impact on the profitability of the economic activity of a manor. Additionally, the owner did not have to worry for agricultural tools or draught animals because the peasantry used its own resources when working for a manor. Rutkowski recapitulates his analysis with a conclusion that serfdom decreased the amount of financial capital required to start production and guaranteed profitability of the economic activity of a manor.

Rutkowski also ponders on the question why the nobility decided to reorganize the agricultural system, instead of, e.g., increasing quitrent in the rent system. The necessity to reorganize the agricultural system resulted from the specificity of the process of production in the rent system, where a peasant controlled agricultural production. He decided which part of the production - after rent, tax and tithe - were paid, was to be devoted to further production, and which to consumption. If rent exceeded a certain amount, a peasant would devote a decreasingly smaller part of income for investment, which resulted in a drop of agricultural production. This phenomenon did not exist in the manorialserf system, where a lord controlled the process of production.

The coexistence of the serfdom of the peasantry and outlets on agricultural producers was a sufficient factor, which influenced a transformation of a rent system into a manorial-serf system. Apart from the above principal factors,

127 Rutkowski, Historia gospodarcza, p. 91. 
a number of secondary factors exerted a varied influence on the processes of European distinctiveness, discussed by Rutkowski. He lists:

factors of geographical nature, such as fertility of soil, navigable waterways, which facilitated trade beneficial for manorial estates, changes in military organization, such as wars devastating the country and, finally, factors of a physical nature, such as traditionalism, influence of religion and Church, national sentiment, etc. ${ }^{128}$

However, the greater part of the above-listed factors exerted only local influence, and neither of them was necessary for a manorial-serf economy to develop. According to Rutkowski, these factors were also present outside Central Europe where a manorial-serf economy did not emerge.

\section{A Recapitulation}

If one takes the method of idealization under consideration when developing a theory explaining particular facts and historical trends, one is obliged to disclose the range of idealizing assumptions, based on which the primary model reduces the influence of some factors to establish a hierarchy of factors determining the phenomenon under study and determine a strategy of concretization. This way, one can avoid arbitrariness and randomness in selecting factors to explain the phenomenon under investigation. However, the greater part of the presented concepts can be charged with the above to a greater or lesser extent. For instance, Blum explains the emergence of the manorial-serf system with four factors: the increased political impact of the lesser nobility, rise of legal power of this stratum of nobility over the peasantry, high demand on grain and weakness of towns.

Blum's concept does not have a strategy of concretization, because the factors present in a given period are not clearly prioritized. Moreover, it is difficult to determine relations between the distinguished factors - i.e. we do not know the relations between the increase of demand for grain in the Western-European countries and the consolidation of legal power of the nobility over the peasantry. Furthermore, the genesis of the weakness of towns is also unclear: was it a result of political supremacy of the nobility in the Central-European countries, or did the underdevelopment of the urban sphere result from other causes, which allowed the nobility to gain political dominance? ${ }^{129}$

128 Rutkowski, Wieś europejska, pp. 222-223.

129 According to I. Schöffer, also relation between the rise of the lesser nobility and introduction of serfdom is unclear: "There is a danger here that the rise of the nobility may be used as a part of explanation of the increase in serfdom at the same time as serfdom is used to explain the rise of the nobility. Blum avoids this pitfall. It is only fair to state 
A reference to a more general theory of historical development gives an advantage of the possibility to determine mutual relations between more detailed concepts. For instance, Rusiński in an analysis of internal factors, which contributed to the development of a manorial-serf economy, claims that political supremacy of the nobility enabled the introduction of an exacerbated serfdom of the peasantry (i). Zientara, in turn, puts forward a more developed explanation. He states that it was the weakness of towns, which allowed the nobility to introduce the manorial-serf system (ii). Absence of theoretical control in putting forward such accounts brings about problems in determining the character of relationships between then. We do not know if statement (ii) is an alternative explanation to statement (i) - it would be, if the political supremacy of the nobility resulted from other causes than the weakness of towns - or is statement (ii) an extension of statement (i) pointing toward further, less direct links in a chain of working factors.

Additionally, if certain explanations do not refer to a broader theory of a historical process, a substantive inconsequence appears. For example, the factor of shortage of workforce initiated the process of developmental differentiation in Europe. Source literature on European modern history regularly underlines the significance of this factor. When combined with the interference of political power on behalf of the owners, this factor brought about an introduction of the system of exacerbated serfdom in Europe. One can often come across the following statements about Central-East Europe in the literature on the subject-matter:

The land/labor ratio had been a permanent historical problem in the East, and after the demographic collapse of the 14th and 15th centuries, labor shortages were even more pronounced. As late as 1600 , population density totaled a mere to 3 to 7 person per square kilometer, equivalent to the land/labor ratio some 10 times higher than that of Western Europe. Faced with vastly underpopulated spaces, the Eastern nobility saw serfdom as the most effective method to squeeze from the potentially productive lands; and with an enserfed labor force, cereal cultivation become the obvious avenue for production within the Eastern environment. ${ }^{130}$

here, that Blum prefers to talk about 'corollaries,' 'inter-related, 'developments', instead of explanations. Even so, one remains a little dissatisfied" (I. Schöffer, "The Second Serfdom in Eastern Europe as a Problem of Historical Explanation," Historical Studies, Vol. 9, No. 3 (1959) p. 48.

130 Hunt, "The Rise of Feudalism in Eastern Europe," p. 55; see also: Schöffler, “The Second Serfdom," p. 48. 
However, an alternative view that the shortage of manpower brought about counter results is also very popular. Namely, that the factor of shortage of manpower, caused by the plague epidemic, contributed to the relaxation and later disappearance of serfdom:

Scarcity of peasants meant a decline not only in the level of rent, but equally in the lord's ability to restrict peasant mobility, and peasant freedom in general. With competition among lords to obtain scarce peasant tenants, one gets according to the laws of supply and demand, not only declining rents in general, and labor services in particular, but giving up by the lords of their rights to control the peasantry. Demographic catastrophe determines the fall of serfdom. ${ }^{131}$

The aforementioned lack of consistency in explaining the consequences of depopulation and the low population density in both parts of the continent is also noted by I. Schöffler. In the eastern part of the continent, the introduction of second serfdom was seen as a reaction to the shortage of manpower, "the landlords in Eastern Europe tried by force to keep the few laborers left to them." ${ }^{132}$ Why did the same factor bring about opposing effects in different parts of Europe: the disappearance of serfdom in the Western part of the European continent and its emergence in Central Europe. According to Schöffler: "In the West the landlords were only able to keep the laborers on their lands by offering them more favourable conditions, i.e. rents instead of labor services."133 This, however, leads to another question: why the landlords in Western Europe were willing to ease the conditions of labor, while in Eastern Europe they were not.

This type of inconsequence can be found in the works of the most distinguished historians. For instance, Marian Małowist claims that the shortage of manpower in the 13th and the 14th centuries pushed feudal lords to grant concessions to the peasantry, a process which manifested by the founding of villages with German Law:

Certainly, in the 13th century the state and the magnates succeeded in bringing the greater part of the peasantry in these countries [of Central Europe] to serfdom, however the income from their obligations was unsubstantial, while the needs of the senior group were growing. Internal and external circumstances and the growing level of culture required an increase of its income. It had to gain more work from the serfs, but increased compulsory work was almost impossible under the then existing circumstances. Depending on the population, still very volatile in some places, the peasantry could avoid compulsory work by escaping from the most demanding lords, particularly if

131 Brenner, “Agrarian Class Structure," pp. 38-39.

132 Schöffler, “The Second Serfdom," p. 48.

133 Schöffler, “The Second Serfdom," p. 48. 
there was a high competition for workforce. [...] For this reason, the local population and foreign colonists had to become interested in a reorganization of economy, particularly in an intensification of agriculture. This objective could have been reached by introducing strong economic stimuli, which were supposed to attract immigrants and encourage the local population to replace old methods of work with more productive ones. [...] Simultaneously, a reorganization of peasant obligations toward the lords and a reduction of their duties toward the state were conducted everywhere. In Bohemia, and shortly thereafter in Poland, it became possible to introduce quit-rent. This giant step forward gave peasants more freedom and encouraged them to work harder. ${ }^{134}$

However, the same factor brought about opposite results three centuries later. According to Małowist: "because of the absence of workforce and financial resources," the nobility "was forced to impose serfdom on the peasantry." 135

Interestingly, the two above-presented theses seem incompatible, however, under certain dissimilar social circumstances may be true. A owner deprived of the support of the state may behave differently than a owner who can ask the state for help in a situation of conflict with direct producers. However, to systematically investigate the problem, one should build a model of an economic society, which eliminates the influence of the distorting factors. Then, one may interrogate the circumstances under which a shortage of manpower stimulates economic concessions and may determine the factors, which bring about a counter-tendency - an increase of exploitation.

134 Marian Małowist, Europa i jej ekspansja XIV-XVI w. (Warszawa: PWN, 1993), pp. 18-19.

135 Małowist, Europa i jej ekspansja, p. 136. 

Part II Methodological Assumptions 



\section{The Method of Idealization in the Historical Sciences}

\section{Idealization in the Social Sciences: Case Studies}

Idealization of the investigated reality is one of the principal methods of research in the contemporary methodology of science. On the force of adopted assumptions, a theoretician examining a given phenomenon does not approach the object of research in all its complexity and complication, but focuses on those aspects of the researched phenomenon recognized from his or her theoretical perspective as principal and substantial, and excludes others, recognized as secondary. Hence, scientific cognition does not depend on faithful imitation of reality, but on its deformation that is able to detect the most significant relations and dependencies. Then, at the second stage of scientific research, the deformed reality becomes more realistic, as the researcher introduces into the simplified approach of the investigated object the secondary aspects, which were omitted in the preliminary model, and which modify the primary laws and dependencies.

The natural sciences have adopted the method of idealization most effectively. For instance, the method of idealization is applied by physicists who create models of point mass, perfect gas or models of black body. They omit the less important aspects of the researched phenomenon and focus on the aspects most essential from their perspective. In the humanities, the procedure of idealization was first and is most broadly used in economics. Therefore, I will present the methodological principles employed by researchers developing economic theories, by analyzing a simple multiplier model of economic growth. ${ }^{136}$

The model comprises two statements:

$$
\begin{aligned}
& C_{t}=c_{0}+m Y_{t} \\
& Y_{t}=C_{t}+I_{t}
\end{aligned}
$$

Key: $Y$ - national product; $C$ - consumption, $I$ - investment, $t$ - period of time; $m$ and $c-$ constants. ${ }^{137}$

136 Lawrence R. Klein, An Introduction to Econometrics (Englewood Cliffe: Prentice Hall, 1962), pp. 251-256; 261-266.

137 This is a simplified variant of the reconstruction presented in: Leszek Nowak, Model ekonomiczny. Studium z metodologii ekonomii politycznej (Warszawa: PWE, 1972), pp. 128-132. 
Lawrence R. Klein concludes his analysis of the model with the following words: "The simple multiplier model is useful in demonstrating some basic principles, but it is hardly a realistic model of a modern economy."138

In the above-presented example, the following factors: the consumption level $\left(C_{t}\right)$, the investment volume $\left(I_{t}\right)$, the difference between import and export $\left(F_{t}\right.$ $\left.-E_{t}\right)$ and the difference between budget expenses and incomes $\left(G_{t}-T_{t}\right)$ are the determinants that exert impact on the value of the national product $\left(Y_{t}\right)$ and the consumption level $\left(C_{t}\right)$. It is obvious that not all from, the above-listed factors influence the variables under study in the same way. We could make a reasonable assumption that the consumption level and the investment level from the initial statement of the multiplier model exert more influence on the value of the national product, in comparison to the difference between export and import, and the difference between budget expenses and incomes. The investment level is also more essential for the consumption level than the above-mentioned difference between export and import, and the difference between budget expenses and incomes. In consequence, to investigate the dependency of variables from the most essential magnitudes, we have to adopt certain simplifying assumptions and exclude less significant factors. The assumptions of the model include the following:

$\left(\mathrm{a}_{1}\right)$ - the investigated variables $Y_{t}$ and $C$ are not influenced by factors not explicitly expressed in the multiplier model; any arbitrary factor external to the model is marked as $P$, hence $\left(P_{t}(x)=0\right)$;

$\left(a_{2}\right)$ - the economy under study is an economy with balanced foreign exchange, hence the value of export equals the value of import $\left(F_{t}(x)-E_{t}(x)=0\right)$; $\left(\mathrm{a}_{3}\right)$ - national budget is balanced - tax income equals national expenses $\left(G_{t}(x)\right.$ $\left.-T_{t}(x)=0\right)$.

The reconstruction of the simplifying procedure of the entire idealizational law that demonstrates the dependency of the social product and the consumption level from the principal factors, can be shown symbolically in the following way:

$$
\begin{aligned}
& P_{t}(x)=0 \wedge F_{t}(x)-E t(x)=0 \wedge G t(x)-T_{t}(x)=0 \rightarrow Y_{t}(x)=C_{t}(x)+I_{t}(x) \\
& P_{t}(x)=0 \wedge F_{t}(x)-E t(x)=0 \wedge G t(x)-T_{t}(x)=0 \rightarrow C_{t}(x)=c_{0}+m Y_{t}(x)
\end{aligned}
$$

The theses of the model apply when we adopt a certain type of simplifying assumptions that are rarely met in real economy.

In the course of further extension of the model, the initially adopted simplifying assumptions are gradually removed. First, we assume that the export value $\left(E_{t}(x)\right)$ is different from the import value $\left(F_{t}(x)\right)$. After this assumption is

138 Klein, An Introduction, p. 251, my emphasis. 
removed, the independent variable - the national product $\left(Y_{t}\right)$ - becomes under influence on other dependent variables in the following way:

$$
\begin{aligned}
P_{t}(x) & =0 \wedge F_{t}(x)-E t(x) \neq 0 \wedge G_{t}(x)-T_{t}(x)=0 \\
& \rightarrow Y_{t}(x)=C_{t}(x)+I_{t}(x)+E t(x)-F_{t}(x)
\end{aligned}
$$

In a similar way, it is considered the question of how the functioning of an open economy influences the consumption value $\left(C_{t}\right)$. A peculiarity of this form of concretization consists in the fact that a removal of the first assumption does not bring about an introduction of amendments to the formulated statement:

$$
P_{t}(x)=0^{\wedge} F_{t}(x)-E t(x) \neq 0 \wedge G_{t}(x)-T_{t}(x)=0 \rightarrow C_{t}(x)=c_{0}+m Y_{t}(x)
$$

Subsequently, we waive the assumption that the budget of the studied economy is balanced. After this assumption is removed, the value of budget incomes $\left(T_{t}\right)$ does not equal budget expenses $\left(G_{t}\right)$. In this more realistic model of economy, the value of the social product is established in the following way:

$$
\begin{aligned}
P_{t}(x) & =0^{\wedge} F(x)-E(x) \neq 0 \wedge G(x)-T(x) \neq 0 \rightarrow Y_{t}(x) \\
& =C_{t}(x)+I_{t}(x)+G(x)+E_{t}(x)-F_{t}(x)
\end{aligned}
$$

The removal of the second assumption on the balanced budget of the economy under analysis causes a modification of the previously formulated second dependency. Then, the level of consumption depends on the following factors in the following way:

$P_{t}(x)=0^{\wedge} F_{t}(x)-E_{t}(x) \neq 0 \wedge G_{t}(x)-T_{t}(x) \neq 0 \rightarrow \mathrm{C}_{t}(x)=c_{0}+m\left(Y_{t}(x)-T_{t}(x)\right)$

The economic theory under study is a sequence of models. The designated simple multiplier model consists of a pair of statements that demonstrate the dependency of two investigated quantities $Y_{t}$ and $C_{t}$ from the most essential factors $Y_{t}$ $C_{t}$ and $I_{t}$. Following from this, the simple multiplier model applies when we are dealing with a number of simplifying assumptions that cause it to be directly inapplicable to real economic systems. However, developed variants of the multiplier model include less simplifying assumptions and demonstrate the dependency of magnitudes under study from the principal and side determinants, such as the difference between export and import, between budget incomes and expenses, and many other that were excluded from the present simplified presentation. In consequence, the developed variants of the multiplier model are closer to real economies, in comparison to the more simplified version of that model.

The two procedures introduced in the above example - the idealization and concretization of the investigated dependencies - are systematically developed 
and analyzed by the idealizational theory of science (hereinafter as ITS). In the present chapter, I will refer to the above example in an attempt to present the principal ideas of the theory and its application to the historical sciences.

\section{The Method of Idealization}

Let us now outline the principal ideas of ITS employed in the present book. ${ }^{139}$ According to ITS, before creating a theory, a researcher identifies factors that influence the phenomenon under analysis. According to his or her empirical knowledge, every magnitude under study $F$ has an array of determinants $\{H$, $\left.p_{k}, \ldots, p_{2}, p_{1}\right\}$ that influence it in a number of ways. All determinants of a given magnitude $F$ create a space of influence. Naturally, these factors influence the studied magnitude to varied degrees. In consequence, we could say that these factors differ with reference to essentiality. The term "essential" and "more essential" are among the most important terms of the idealizational theory of science. According to this conception, magnitude $H$ is essential to magnitude $F$ if the adoption of a certain value by $H$ excludes the possibility of the adoption of any value by $F^{140}$ The influence of one factor on another is, hence, determined by a

139 Leszek Nowak put forward the first description of the idealization method in: Leszek Nowak, "O zasadzie abstrakcji i stopniowej konkretyzacji," in: Założenia metodologiczne "Kapitału" Marksa, ed. Jerzy Topolski (Warszawa: KiW, 1970), pp. 123-218; for further developments, see: Leszek Nowak, U podstaw Marksowskiej metodologii nauki (Warszawa: PWN, 1971), Leszek Nowak, Zasady marksistowskiej filozofii nauki. Próba systematycznej rekonstrukcji (Warszawa: PWN, 1974), Leszek Nowak, Wstęp do idealizacyjnej teorii nauki (Warszawa: PWN, 1977), Leszek Nowak, The Structure of Idealization. Towards a Systematic Interpretation of the Marxian Idea of Science (Dordrecht: Reidel, 1980); and for a review of the development and implementation, and a discussion of the concept of idealization, see: Leszek Nowak and Izabela Nowakowa, Idealization X: The Richness of Idealization (Amsterdam/New York: Rodopi, 2000). For the recent studies on Idealizational Theory of Science, see: Giacomo Borbone, “The Legacy of Leszek Nowak," Epistemologia, Vol. 34, No. 2 (2012), pp. 227-252; Giacomo Borbone, "Leszek Nowak and Idealizational Approach to Science," Linquistic and Philosophical Investigations, Vol. 10 (2011), pp. 125149, Giacomo Borbone, Questioni di metodo. Leszek Nowak e la scienza come idealizzazione (Roma: Acireale, 2016); Francesco Coniglione, Realta e astrazione. Scuola polacca ed epistemologia post-positivistica (Roma: Acireale/Bonnano, 2008).

140 The first explication of the term of influence was in: Leszek Nowak, "Byt i myśl. Przyczynek do metafizyki unitarnej,” Studia Filozoficzne, No. 1 (1989), p. 14. The explication present in this book is based on the modification provided by Katarzyna Paprzycka and Marcin Paprzycki "A Note on the Unitarian Explication of Idealization," in: Idealization III: Approximation and Truth, eds. Jerzy Brzeziński and Leszek Nowak (Amsterdam - Atlanta, GA: Rodopi, 1992), pp. 279-283. 
set of values $W_{F}(H)$ that the magnitude studied cannot adopt. The set $W_{F}(H)$ can be also named a strength or power of influence of factor $H$ on magnitude $F$ under analysis. I am going to use these terms alternatively. Such an account of essentiality also makes it possible to explain the concept of being "more essential." Magnitude $H$ is more essential to $F$ if the power of influence of magnitude $H$ on $F$ exceeds the power of influence of the factor $p$ on $F$. This can be demonstrated graphically in the following way:

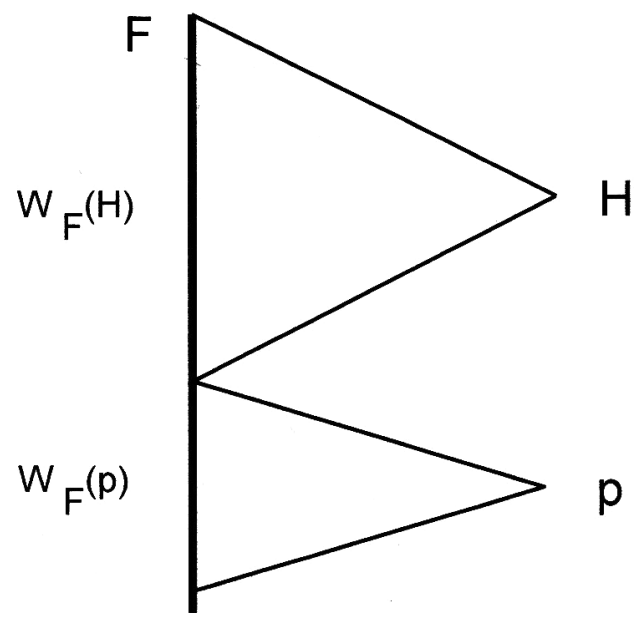

Fig. 1: The power of influence of factors $H$ and $p$ on $F$. Explanations: $W_{F}(H)$ - the domain of influence of the factor $H$ on $F ; W_{F}(p)$ - the domain of influence of factor $p$ on $F$.

Thus, the above figure demonstrates the power of influence of factors $H$ and $p$ on the phenomenon under study. The power of influence of the factor $H$ is greater than the power of influence of the factor $p$ if the set $W_{F}(H)$ is composed of more elements than the set $W_{F}(p)$; hence, the factor $H$ is more essential to the magnitude $F$ than the factor $p$.

With the use of the terms "essential" and "more essential," it is possible to reconstruct the essential structure of the studied magnitude by distinguishing three kinds of influence exerted by any factor $n_{i}$ on the magnitude $F$ :

- maximal - if a factor $n_{i}$ adopting a value $a_{i}$ excludes $N_{F}-1$ of the values assumed by the magnitude $F$, what means that the value adopted by $F$ is strictly determined by factor $n_{i}$;

- predominant - if the factor $n_{i}$ assuming value $\mathrm{a}_{i}$, excludes the majority of values adopted by the magnitude $F$ from the set $N_{F}$; 
- minimal - if the factor $n_{i}$ excludes the minority of values of the magnitude $F$ from the set $N_{F}$ (in extreme situations only one value).

In the conceptual apparatus of ITS, the principal factors exert maximal and predominant, influence, whereas secondary factors exert the minimal influence. This enables recreation of a hierarchy of influence of individual factors and, in turn, reconstruction of the essential structure of a phenomenon under investigation. The procedure depends on the identification of factors that affect the analyzed magnitude in any way and on the ordering of the power of influence from the strongest to the weakest. The order of the power of influence of several factors on the phenomenon under study can be demonstrated graphically in the following way:

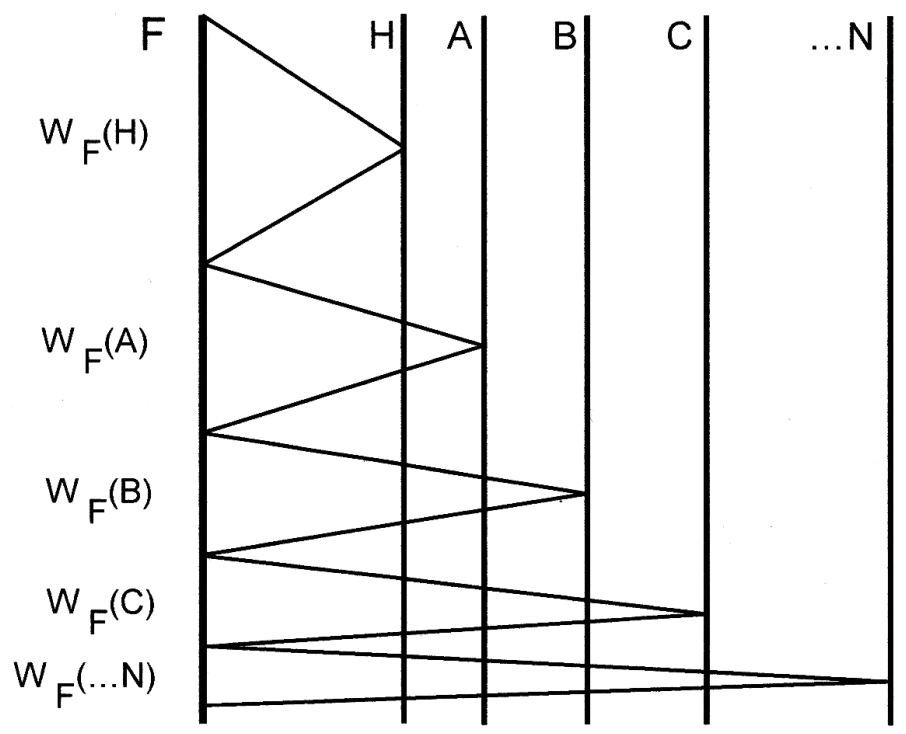

Fig. 2: The order of the power of influence of the factors $H, A, B, C, D, \ldots, N$ on $F$. Explanations: the order of the power of influence of particular factors on the phenomenon $F$ under analysis, i.e. $\langle H, A, B, C, \ldots, N>$ indicates that the power of influence of the factor $H$ of the analyzed phenomenon $F$ is the greatest, as the set $W_{F}(H)$ contains the largest number of elements. The power of influence of the factor $A$ in consideration of the studied phenomenon $F$ is lesser than $H$ but greater than $B$, as the set $W_{F}(A)$ contains fewer elements than the set $W_{F}(H)$ but more elements than the set $W_{F}(B)$, etc. The smallest power of influence is characteristic for the factor $N$, as the domain of influence on the examined phenomenon $F$ is the smallest. 
The essential hierarchy of determinants in the space of factors essential to $F$ makes it possible to recreate the essential structure of the magnitude under investigation. If in the structure, the strength of influence of the factor $H$ exceeds the strength of influence of the other factors $p_{k}, \ldots, p_{2}, p_{1}$, then the factor $H$ is the principal factor for the studied magnitude and the other factors belong to the class of secondary factors - each one of them eliminates the minority of values of the magnitude $F$ from the set $N_{F}$. The essential structure of the magnitude can be presented in the following way:

$$
\begin{array}{ll}
S_{F}: & (\mathrm{k}) H \\
& (\mathrm{k}-1) H, p_{k} \\
& \ldots \ldots \ldots \ldots \\
& (1) H, p_{k} \ldots, p_{2} \\
& (0) H, p_{k} \ldots, p_{2}, p_{1}
\end{array}
$$

There is only one principal factor $H$ at the deepest internal level of essentiality of the essential structure of the magnitude $F$. Further levels of essentiality of the essential structure of the magnitude $F(k-1), \ldots$, (1) include a number of secondary factors. The surface level ( 0$)$ of the essential structure includes all factors that somewhat influence the magnitude $F$ under study.

Let us notice that in the example under study, the determining factors of the national product $(Y)$ are ordered in a similar way. The deepest level of essentiality of the essential structure of the national product $\left(Y_{t}\right)$ contains the following factors: the consumption level $\left(C_{t}\right)$ and the investment level $(I)$. The surface level of essentiality, apart from these two factors, additionally contains the difference between import and export $(E-F)$ and the difference between the amount of budget incomes and expenses $(G-T)$.

Additionally, the distinction between the power of influence of individual factors enables to differentiate two basic kinds of essential structures:

(1) dominated by the essence, with the power of influence of the principal factor (exerting maximal or predominant influence) higher than the sum of the strength of powers of influence of all secondary factors;

(2) dominated by accidentals where the sum of the strength of power of influence of secondary factors is higher than the power of influence of the principal factor.

Following a reconstruction of the essential structure of the magnitude $F$ under study, a researcher reconstructs its nomological structures. Such a structure consists of a sequence of dependencies manifesting connections between the investigated 
magnitude and the factors present at different levels of essentiality. The dependency $f_{k}$ connecting the magnitude $F$ under analysis with its principal determinant is termed regularity. The dependency $f_{k-1}$ describes how the factor $H$ and the secondary factor $p_{k}$ influence the magnitude $F$. This dependency consists of two functions: the regularity $f_{k}$ defining the influence of the principal factor $H$ and the corrective function $h\left(p_{k}\right)$ defining the impact of the secondary factor $p_{k}$ on the magnitude $F$.

In terms of ITS, the function $f_{k-1}$ is also named a directional function because it demonstrates how the influence $h\left(p_{k}\right)$ of the factor $p_{k}$ modifies the impact of the principal factor $H$ on the magnitude $F$. This kind of dependency that manifests connections between magnitudes under investigation and secondary factors present at further levels of essentiality is a form of manifestation of regularity of the further rows - the first, the second, etc.

The notion of essential structure should be distinguished from the notion of the image of the structure. The essential structure is the actual hierarchy of factors influencing the magnitude $F$ under study. The image of the essential structure is a construct developed by a researcher under the - correct or incorrect - assumption that the particular factors are the principal or the secondary ones for the magnitude $F$. The image of the essential structure is identical to the structure itself when the factor assumed by the researcher to be principal, is actually the principal factor, and the factors assumed to be secondary, are actually secondary factors for the essential structure of the magnitude under investigation. For this reason, the image of the essential structure can vary from the scope of the essential structure, and the level of truthfulness of the statements adopting images of the essential structure can be different. ${ }^{141}$

The range of scientific theory can be fully adequate, partially adequate and inadequate with the scope of the given theory. The scientific theory is fully adequate when range $U$ of the essential structure recreated by a researcher is identical with scope $Z$ of the essential structure of the magnitude $F .^{142}$ In the class of partially adequate theories, we can distinguish too narrow, too broad, and "jumping" theories. The theory is too narrow where range $U$ advocated by a researcher is a proper subset of the scope $Z$. The theory is too broad where scope $Z$ is proper superset of range $U$. In the case of a "jumping" theory, image $U$ and scope $Z$ non-emptily intersect each other. The theory is inadequate when the intersection of elements belonging to a range $U$ and a scope $Z$ is empty.

141 For more on the subject, see: Izabela Nowakowa, $Z$ problematyki teorii prawdy $w$ filozofii marksistowskiej (Poznań: UAM, 1977).

142 Nowak, Nowakowa, Idealization X: The Richness, pp. 399-406. 
To conclude, the method of idealization consists in the minimization of the influence of factors perceived as exerting secondary influence on the magnitude under study. Based on the idealizing assumption,

$$
p_{i}(x)=0,
$$

we assume that, when it takes on a null value, the factor $p_{i}$ does not impact the magnitude under analysis. As a result, a statement can be formulated that the analyzed magnitude $F$ depends solely on its principal factor. For quantitative cases, the statement can be presented in the following way:

$$
U(x) \wedge p_{k}(x)=0 \wedge p_{k-1}(x)=0 \wedge, \ldots, \wedge p_{1}(x)=0 \rightarrow F(x)=f_{k}(H(x))
$$

The above-formulated statement is the idealizational law. Its antecedent consists of counter-factual assumptions adopting that all secondary factors do not exert any influence on the magnitude under study. Such assumptions are met empty in the empirical world where the analyzed phenomena are subject to the influence of principal and secondary determinants. However, by adopting such assumptions, it is possible to demonstrate how the magnitude $F$ under investigation depends on the principal factor $H$.

\section{The Idealizational Law and Its Concretization}

The procedure of idealization is only one of the sides of theory building. The other side is the procedure of concretization of the idealizational law that demonstrates how the object under analysis depends not only on the principal factors, but also on the secondary determinants that modify the basic laws and dependencies.

According to ITS, the procedure of concretization consists in gradual removal of preliminarily adopted idealizing assumptions and in introduction of appropriate amendments to the formula of the starting statement. The antecedent of the idealizational law adopts a realistic assumption that the value of one of the secondary factors varies from the minimal value it was appropriated with in the idealizing assumption. Afterwards, it is determined how this factor modifies the preliminarily determined basic dependencies. The concretization procedure has a determined order. First, the idealizing assumptions that concern the factors from the class of secondary factors that exert the highest influence on the studied magnitude are removed. Afterwards, the influence of the secondary factors that exert less influence on the analyzed magnitude is taken under consideration. Hence, the concretized idealizational statement has the following shape:

$$
U(x)^{\wedge} p_{k}(x) \neq 0 \wedge p_{k-1}(x)=0 \wedge, \ldots, \wedge p_{l}(x)=0 \rightarrow F=f_{k-1}\left(H(x), p_{k}(x)\right)
$$


The idealizing assumption that the value of the factor $p_{k}(x)$ equals zero was removed in the antecedent of the above statement. The assumption was substituted with a thesis stating that the above-mentioned factor adopts another value different than zero. The consequent of the statement demonstrated how one of the concretized secondary factors modifies the dependencies that affect the magnitude under study. Hence, the dependency $f_{k-1}$ demonstrating the impact of the principal factor $H$ and one of the secondary factors $p_{k}$ is the first form of manifestation of regularity. This regularity is a superposition of two dependencies: the dependency $f_{k}$ taking place between the magnitude $F$ and the principal factor $H$, and the dependency occurring between the studied magnitude and the secondary factor $p_{k}$. Thus, this factor modifies the starting dependencies established in the idealizational law.

The concretization procedure concludes with a formulation of a statement that does not include any of the idealizing assumptions. Hence, the final concretization of the idealizational law is a factual statement.

Another form of concretization is the degenerate concretization. It takes place when the removal of one of the idealizing assumptions does not modify the dependency that the investigated magnitude is subjected to (an "empty amendment" occurs). An example of a degenerate concretization in a simple multiplier model of the economic growth is the inclusion of the influence of the difference between export and import $\left(F_{t}(x)-E_{t}(x)=0\right)$ on the consumption value.

In the research practice, scientists do not implement a final concretization where all simplifying assumptions of the idealizational law are removed. Usually, after implementing a series of concretizations, the influence of other, less essential secondary factors is determined via approximation. It consists in a process where secondary factors are attributed values that vary from the minimal values attributed to factors in idealizing assumptions and from empirical ones. In the formulated approximation statement, $F(x)$ only approximately equals the value of function $f_{k-1}$ that expresses the dependency of the magnitude under investigation from the approximated determinants. The above difference is demonstrated by the variable $\varepsilon$ referred to as the threshold of approximation.

Every idealizational theory is a sequence of models differentiated by a number of adopted idealizing assumptions. Model I of the theory demonstrates the studied dependencies solely on the principal factors, therefore, it comprises of a number of idealizational laws of the above type. The initial statement excludes the influence of secondary factors on the phenomena under analysis. However, it allows a researcher to focus on the determinants principal for the studied phenomena, by omitting the impact of the incidental factors. Further developed models examine the impact of the secondary factors on the investigated 
phenomena. They include less idealizing assumptions and are closer to the empirical reality.

Idealizational scientific theories can have various structures. The basic kinds are the linear structure and the star structure idealizational theory. In the scientific theory of a linear structure, new secondary factors are introduced into the last model of the given theory gradually reducing the number of idealizing assumptions.

In the theory of a star-like structure, there is a central basic model with $k$ idealizing assumptions and a set of derivative models with $k-1$ idealizing assumptions. A scientist using the star-like structure type of theory, when approaching an analysis of the influence of a given secondary factor on the phenomenon under investigation, waives one of the idealizing assumptions of the basic model and develops a derivative model with $k-1$ idealizing assumptions. However, if a theoretician aims to analyze the impact of another secondary factor, he/she does not continue the process of concretization of the derivative model by, e.g., building a model with $k-2$ idealizing assumptions but, instead, reinstates the idealizing assumption removed in the first derivative model, he/ she "returns" to the basic model. Only then, the theoretician waives one of the idealizing assumptions of the basic model required to investigate the secondary factor he/she finds interesting, and builds another derivative model also with $k-1$ idealizing assumptions.

The multiplier model recreated here has a linear structure. First, one of the statements of the simple multiplier model demonstrating dependencies between the magnitude of the national product $\left(Y_{t}\right)$ and the consumption level $\left(C_{t}\right)$ and the investment level $\left(I_{t}\right)$ is broadened by a derivative variant investigating the influence of the difference between export and import $\left(E_{t}-F_{t}\right)$ on the level of the national product $\left(Y_{t}\right)$. Second, a new secondary factor that is included in the difference between budget incomes and expenses $\left(G_{t}-T_{t}\right)$ is introduced into the concretized variant of a simple multiplier model. Hence, a further-developed multiplier model, which is a concretization of a simple multiplier model, demonstrates the simultaneous impact of two secondary factors: the difference between export and import, and the difference between budget expenses and incomes.

The explanation why the magnitude $F$ on the object $a$ has a particular value consists in demonstration of a dependency connecting the magnitude $F$ with the principal factor $H^{143}$ Subsequently, increasingly realistic concretizations are derived from the idealizational law with such formula. The concretizations

143 Verification of the idealizational theory is possible at every its stage. However, there is a difference between verification of its "factual" and "idealization" part. Factual 
of the idealizational law that include the impact of secondary factors demonstrate how the factors modify the impact of the basic regulations that the studied magnitude $F$ is subject to. The procedure of concretization concludes with a formulation of a factual statement that does not include any idealizing assumptions in the antecedent. The explained statement results from a factual statement formulated based on the procedure of concretization and its starting conditions.

\section{Operationalization of the Idealizational Theory}

Operationalization, or a procedure of attributing theoretical concepts with an empirical sense, is one of the significant aspects of ITS. Let us now discuss the approach toward this issue developed by Elżbieta Hornowska. ${ }^{144}$ According to the concept, every theoretical factor $A$ has an area of influence $W_{A}{ }^{1}$. The direct area of influence includes all factors that factor $A$ is essential to. The indirect area of influence of the factor $A$ includes all factors that the factors from the direct area of influence $W_{A}{ }^{1}$ are essential to. This type of dependency between the theoretical factor $A$ and the factors belonging to the indirect area of influence occurs when factor $A$ is essential to $B$, and $B$ is essential to $C$. In consequence, the factors of type $C$ create an area of influence of the theoretical factor $A$ of the second level $W_{A}^{2}$. The sum of sets $W_{A}{ }^{1}, \ldots, W_{A}^{\mathrm{q}}$ creates the sum of all areas of influence of the factor $A$.

In the area of influence of the theoretical factor $A$, one can differentiate an area of its identification. Let us now assume that $W_{A}{ }^{1}$ is the first area of influence of the theoretical factor $A$ that includes an observable factor $Q$. This factor

statements can be directly referred to reality. However, in order to verify statements including idealizing assumptions, we have to create conditions where the impact of the excluded secondary factors equals zero. Then, in the conditions of a perfect experiment, the principal factor is attributed with a value $k(r)$. Afterwards, we check if the magnitude $F(a)$ acquires the assumed value $k(r)$. The idealizational law is confirmed if the analysed magnitude $F(a)$ acquires the adopted value $k(r)$. If the magnitude $F(a)$ adopts a value different from $k(r)$, the idealizational law is falsified.

144 Cf. Elżbieta Hornowska, Operacjonalizacja wielkości psychologicznych. Założenia Struktura - Konsekwencje (Wrocław: Ossolineum, 1989), pp. 52-61; Elżbieta Hornowska, "A Certain Approach to Operationalization," in: Idealization II: Forms and Application, eds. Jerzy Brzeziński, Francesco Coniglione, Theo A. F. Kuipers and Leszek Nowak (Amsterdam-Atlanta: Rodopi, 1990), pp. 77-86. 
is an identifier of the theoretical factor $A$ if there are observable states of affairs that depend on the value of the theoretical factor for particular objects. A set of identifiers of such kind creates an area of identification of the theoretical factor $A$ in its space of influence. Every identifier $Q$ has a particular essential structure. Depending on the place taken by the theoretical factor $A$ in the essential structure of the factor $Q$, one can distinguish identifiers of the factor $A$ of varied accuracy. Factor $Q$ is a more accurate identifier for the theoretical factor $A$ if this magnitude is the principal factor for the given identifier, in comparison to a situation when the theoretical factor $A$ is a secondary factor.

An ontological thesis of empiricism is formulated in the above-described conceptual apparatus. According to this thesis, every theoretical factor has an area of empirical identification in its space of influence. As a result, there are no theoretical factors that without observable implications.

The procedure of operationalization consists of three stages. In the first stage, a scientist constructs a magnitude, which is a theoretical image of a factor. In the second stage, a researcher reconstructs the areas of influence of this magnitude. In the third stage, a scientist identifies the area of empirical identification. It is relied on finding an observable magnitude $B$ connected to the theoretical magnitude $A$ with a relation of (usually indirect) significance-consequence. Therefore, a scientist determines how the theoretical magnitude is manifested on the observatory level. As a result of this cognitive operation, the magnitude is transformed into a variable (operationalized magnitude).

According to Elżbieta Hornowska, operationalization varies from measurement. Measurement, a procedure external from operationalization, consists in a transformation of the variable into a set of scale values that describe it. Only then, based on the adopted rules of operationalization and measurement of the values of a variable, a theoretical image of factor $A$ is fully reconstructed.

\section{On Some Extensions of the Idealizational Theory of Science}

\subsection{On Different Kinds of Counter-Factual Assumptions}

The above sections from 2 to 4 presented the general essential features of ITS. A further development of the conception occurred in the direction of refining the above-drafted initial image, or amending it. The point of departure of the process of refining the ITS image was an observation that the antecedents of the formulated counter-factual statements include assumptions that do not fully satisfied criteria of the idealizing assumption. These counter-factual assumptions include aggregating, quasi-idealizing and stabilizing assumptions. 
An aggregating assumption consists in simplifying the internal structure of the magnitude under interrogation. ${ }^{145}$ This assumption adopts that the composition or structure of the studied factors does not influence the formulated dependencies. An aggregating assumption is removed in the process of disaggregation. Then, the internal structure of the studied factors is treated as if it was an additional factor with an influence that modifies the dependencies established preliminarily with the adoption of aggregating assumptions.

The quasi-idealizing assumption is an assumption that is satisfied under a number of conditions. ${ }^{146}$ Let us now assume that there is a universe where factor $p$ is determined. In the subset $K$ of the universe $U$, $p$ really takes on null value: for $x \in K: p(x)=0$. Magnitude $p$ ascertained on objects belonging to the remaining part of the set $U$ adopts values different than minimal: for $y \in U-K: p(y) \neq 0$. Objects from the set $K$, on which the magnitude $p$ adopts minimal values belong to a range of realization of the quasi-idealizing assumption, and objects from the set $U-K$, on which the magnitude $p$ adopts values different from zero, belong to a range of idealization of quasi-idealizing assumption.

The distinguishing of quasi-idealizing assumptions allows a deeper characterization of the type of the adopted simplifying assumptions in the simple multiplier model analyzed above. The simplifications concerning the balance between import and export or the possible balance between budget incomes and expenses are, in fact, quasi-idealizing assumptions. Such conditions can be idealizing assumptions only when, for example, the difference between the value of export and import of a particular economy does not equal zero, therefore, it does not adopt the minimal intensity. Conditions that are, to our knowledge, met in the empirical world are not idealizing assumptions.

In the course of a limited concretization, the quasi-idealizing condition is removed. Two statements are derived from an idealizing assumption that has

145 Cf. Nowak, Zasady marksistowskiej filozofii nauki, pp. 50-51. In his study devoted to the concept, Krzysztof Łastowski distinguished inter-level and between-level factors. Inter-level magnitudes affect only one level of complexity of an analysed object. Between-level magnitudes affect at least two levels of complexity of a given object. Therefore, in accordance with aggregating assumptions, a given between-level magnitude is treated as an inter-level magnitude. See: Krzysztof Łastowski, Rozwój teorii ewolucji. Studium metodologiczne (Poznań: Wyd. UAM, 1987); Krzysztof Łastowski, "On Multi-Level Scientific Theories," in: Idealization II: Forms and Application, eds. Jerzy Brzeziński, Francesco Coniglione, T.A.F. Kuipers and Leszek Nowak (Amsterdam-Atlanta: Rodopi, 1990), pp. 33-59.

146 Nowak, Zasady marksistowskiej filozofii nauki, pp. 123-129. 
a quasi-idealizing assumption in the antecedent. The first statement is limited to the range where the assumption is met. Hence, such concretization does not bring any added value to the preliminarily adopted dependencies. The second statement concerns the range where the condition really is the idealizing condition. In this case, the implementation of a concretization modifies the initial dependencies, but its correction is limited to the range where the concretized assumption has a character of idealization.

Another type of counter-factual assumption is a stabilizing assumption. ${ }^{147}$ It occurs when a given variable does not assume the minimal value but a particular constant value. The removal of the stabilizing assumptions is termed a destabilization. It consists in assuming that a given factor does not adopt a particular constant value $d$, but a different value.

\subsection{On the Specification of Idealizational Statements}

Note that the combination of the procedure of concretization with the recreation of the range is associated with another procedure that is yet to be conceptualized. I will term it the specification of the range of theory. Let us assume that we have a theory of the factor $F$ with the range identical to the scope of the essential structure determined in this statement. Hence, the essential structure in the range $L$ has the following form:

$$
\begin{array}{r}
S_{F}^{L}: H \\
H, p
\end{array}
$$

However, in some sub-ranges, the theory $T_{F}$ is subject to additional factors. For example, in the sub-range $L_{1}$ it is subject to factor $q$, and in sub-range $L_{2}$ - to factor $r$.

$$
\begin{array}{cc}
S_{F}{ }^{L 1}: H & \mathrm{~S}_{F}{ }^{22}: H \\
H, p & H, p \\
H, p, g & H, p, r
\end{array}
$$

In this case, a specification of the theory $T_{F}$ is implemented. First, the initial range of validity of the theory is narrowed down to the factors $H$ and $p$. Second, the influence of the secondary factors $g$ and $r$ on the magnitude $F$ is determined,

147 Cf. Piotr Chwalisz, "Stałe w teorii idealizacyjnej," in: Odkrycie, abstrakcja, prawda, empiria, historia a idealizacja, eds. Andrzej Klawiter and Leszek Nowak (WarszawaPoznań: PWN, 1979), pp. 99-104. For more on the reconstruction of stabilizing statements, see: Renata Zielińska, Abstrakcja, idealizacja, generalizacja. Próba analizy metodologicznej (Poznań: Wyd. UAM, 1981), p. 43. 
and the range of these factors is established. They do operate in the entire range of validity of the theory, but in particular sub-ranges $L_{1}$ and $L_{2}$.

The modified statement for range $L_{1}$ after the implementation of a specification of the theory can be demonstrated in the following way:

$$
\begin{aligned}
& L_{1}(x) \wedge q(x)=0^{\wedge} p(x)=0 \rightarrow F(x)=f_{k}(H(x)) \\
& L_{1}(x) \wedge q(x)=0^{\wedge} p(x)=0 \rightarrow F(x)=f_{k-1}(H(x), p(x)) \\
& L_{1}(x) \wedge q(x)=0^{\wedge} p(x)=0 \rightarrow F(x)=f_{k-1} \prime(H(x), p(x), q(x))
\end{aligned}
$$

Whereas, the modified statement of the second sub-range can be demonstrated in the following way:

$$
\begin{aligned}
& L_{2}(x) \wedge r(x)=0 \wedge p(x)=0 \rightarrow F(x)=f_{k}(H(x) \\
& L_{2}(x) \wedge r(x)=0 \wedge p(x)=0 \rightarrow F(x)=f_{k-1}(H(x), p(x)) \\
& L_{2}(x) \wedge r(x)=0 \wedge p(x)=0 \rightarrow F(x)=f_{k-1}{ }^{\prime}(H(x), p(x), r(x))
\end{aligned}
$$

Chronological specification is a variant of the specification of the idealizational theory. The image of the essential structure and the idealizing statements are relativized to range and, additionally, to time. ${ }^{148}$ Let us consider the idealizational theory of the factor $F$ concerning the impact of the principal factor $H$ and the secondary factor $p$, relativized to the period of time. Let us assume that in intervals $T$ the magnitude under study is additionally influenced by other secondary factors. In such case, a scientist also narrows down the initial time range of validity of the theory $T_{F}$ with active factors $H$ and $p$, determines the influence of the additional factors $q$ and $r$ on the magnitude under investigation, and establishes the range of their influence. $L_{1}$ is interpreted as an interval with the first essential structure in force, and $L_{2}$ - with the second essential structure in force.

The combination of the two types of specification described above is a chronological-territorial specification. In this case, we determine the sub-range of the impact of the factors $q$ and $r$, as well the interval $T$ in which these factors are in force. After the implementation a chronological-territorial specification of

148 Relativization of the influence of essential factors present in the essential structure of a particular phenomenon to time is investigated in the categorical ontology. This approach allows to, i.e. study the reshaping of the essential structure of the phenomenon under analysis, and the relations occurring between reshaping of the essential structures and the changes in the structure of the scientific theories providing explanation of the particular phenomena. For more, see: Leszek Nowak, U podstaw dialektyki marksowskiej. Próba interpretacji kategorialnej (Warszawa: PWN, 1977), Andrzej Michał Witkowski, Z problematyki zmienności indywiduów. Przyczynek do ontologii kategorialnej (Poznań: Nakom, 1992). 
the factors $q$ and $r$, the statements of the idealizational theory of the magnitude $F$ can be demonstrated in the following way (to simplify, I have assumed that the factors $q$ and $r$ operate in the same interval $\left.t_{2}\right)$ :

$$
\begin{aligned}
& L\left(x, t_{1}\right) \wedge q\left(x, t_{1}\right)=0 \wedge r\left(x, t_{1}\right)=0 \wedge p\left(x, t_{1}\right)=0 \rightarrow F\left(x, t_{1}\right)=f_{k}\left(H\left(x, t_{1}\right)\right) \\
& \left.L\left(x, t_{1}\right) \wedge q\left(x, t_{1}\right)=0 \wedge r\left(x, t_{1}\right)=0 \wedge p\left(x, t_{1}\right) \neq 0 \rightarrow F\left(x, t_{1}\right)=f_{k-1}\left(H\left(x, t_{1}\right)\right), p\left(x, t_{1}\right)\right) \\
& L_{1}\left(x, t_{2}\right) \wedge q\left(x, t_{2}\right) \neq 0 \wedge r\left(x, t_{2}\right)=0 \wedge p\left(x, t_{1}\right) \neq 0 \rightarrow \\
& \left.F\left(x, t_{2}\right)=f_{k-1}\left(H\left(x, t_{2}\right)\right), p\left(x, t_{2}\right), q\left(x, t_{2}\right)\right) \\
& L_{2}\left(x, t_{2}\right) \wedge q\left(x, t_{2}\right)=0 \wedge r\left(x, t_{2}\right) \neq 0 \wedge p\left(x, t_{2}\right) \neq 0 \rightarrow \\
& \left.F\left(x, t_{2}\right)=f_{k-1}\left(H\left(x, t_{2}\right)\right), p\left(x, t_{2}\right), r\left(x, t_{2}\right)\right) \\
& L\left(x, t_{3}\right) \wedge q\left(x, t_{3}\right)=0 \wedge r\left(x, t_{3}\right)=0 \wedge p\left(x, t_{3}\right) \neq 0 \rightarrow F\left(x, t_{3}\right)=f_{k-1}\left(H\left(x, t_{3}\right), p\left(x, t_{3}\right)\right)
\end{aligned}
$$

\section{The Comparative Method and Idealization}

The comparative method is one of the basic strategies of building scientific theories in comparative historical sociology. ${ }^{149}$ The present book offers a comparison of the socio-historical development of Bohemian, Polish, and Hungarian societies; therefore, it is worth considering the methodological assumptions of the abovementioned method. Victoria E. Bonnell distinguishes between two basic comparative methods: "illustrative" and "analytical." In the case of illustrative comparison:

The main point of comparison is between equivalent units, on the one hand, and the theory or concept on the other. This variant evaluates individual units on the one hand and a theory or concept on the other. This variant evaluates individual units not in relation to each other but in relation to a basic theory or concept applicable to all of them. ${ }^{150}$

Whereas, in the analytical comparison:

The main point of comparison is between or among equivalent units. The comparison involves an identification of independent variables that serve to explain common or contrasting patterns of occurrences. The investigator juxtaposes equivalent units with each other in order to discern regularities that might provide explanatory generalisations. ${ }^{151}$

149 For other classifications of the comparative method, see: Stephen Kalberg, Max Weber's Comparative Historical Sociology (Cambridge: Polity Press, 1994); Matthew Lange, Comparative-Historical Methods (Thousands Oaks, CA: Sage, 2013); Charles Tilly, As Sociology Meets History (New York: Academic Press, 1981); Charles Tilly, Big Structures, Large Processes, Huge Comparisons (New York: Russell Sage Foundation, 1984).

150 Victoria E. Bonell, "The Uses of Theory, Concepts and Comparison in Historical Sociology," Comparative Studies in Society and History, Vol. 22 (1980), p. 165.

151 Bonell, "The Uses of Theory, Concepts and Comparison," pp. 164-165. 
The two types of comparative methods are distinguished based on the criterion of the place of the theoretical assumptions in the comparison. In the illustrative type of comparison, a researcher has a ready theory and he/she uses the cases under comparison to determine the range of application of the theory. The analytical strategy hinges on the assumption that the comparison itself leads to a formulation of a theory comprised of the cases under comparison.

Theda Skocpol and Margaret Somers offered an alternative classification of the comparative method differentiating the following types of comparative history: parallel, contrast-oriented and macro-causal. According to Skocpol and Somers, the parallel comparative history:

serves as an ancillary mode of theoretical demonstration. Historical instances are juxtaposed to demonstrate that the theoretical arguments apply convincingly to multiple cases that ought to fit if the theory in question is indeed valid. Cases are selected to cover all possibilities, or to represent a range of sub-types or points on continua. The point of the comparison is to assert a similarity among the cases - similarity, that is, in terms of the common applicability of the overall theoretical arguments. ${ }^{152}$

It is characteristic for the above-described comparative method "to elaborate theoretical models and hypotheses before turning to historical case illustrations."153 For this reason, the parallel method is similar to the illustrative method from Bonnell's classification.

The second type of comparative method consists in searching for contrasts in the cases under comparison. The purpose of this strategy is to: "bring out the unique features of each particular case included in their discussions, and to show how these unique features affect the working-out of putatively general social processes." 154

Unlike in the parallel method, the researchers employing the contrastoriented comparative method "aim to place historical limits on overly generalized theories, but they do not aspire to generate new explanatory generalization through comparative historical analysis." 155

Finally, Skocpol and Somers differentiate the macro-causal comparative strategy that consists in a combination of the two approaches: parallel and contrast-oriented. On the one hand, the scientists implementing this method

152 Theda Skocpol and Margaret Somers, "The Uses of Comparative History in MacroSocial Inquiry," Comparative Studies in Society and History, Vol. 22 (1980), pp. 176-177.

153 Skocpol, Somers, “The Uses of Comparative History," p. 177.

154 Skocpol, Somers, “The Uses of Comparative History," p. 178.

155 Skocpol, Somers, “The Uses of Comparative History," p. 178. 
"can try to establish that several cases having in common the phenomenon to be explained also have in common the hypothesized causal factors, although the cases vary in other ways that might have seemed causally relevant." ${ }^{156}$

At the same time, however, the scientists implementing the macro-causal comparative analysis can "contrast cases in which the phenomenon to be explained and the hypothesized causes are present to other ('negative') cases in which the phenomenon and the causes are both absent, although they are as similar as possible to the 'positive' cases in other respects."'157

Macro-causal analysis was fully applied in Skocpol book States and Social Revolutions. In methodological introduction to this book Skocpol stressed that: "Comparative historical analysis is not substitute for theory. Indeed, it can be applied only with the indispensable aid of theoretical concepts and hypotheses." 158 However, in the meta-methodological discussion over this book Skocpol argued that:

the causal arguments positively invoked in States and Social Revolutions are not derived from a pre-existing theory of revolution, this is very true - and the great advantage of the book lies precisely in this fact! How are we ever to arrive at new theoretical insights if we do not let historical patterns speak to us, rather than always viewing them through the blinders, or the heavily tinted lenses, of pre-existing theories? ${ }^{159}$

Skocpol admits in this paper that certain elements of theoretical reasoning are indispensable in the comparative method which is creative synthesis of deduction and induction. However, the relations between these to elements of comparative research are unclear. In order to clarify these relationships, I would like to explicate three types of comparative analysis: parallel contrast-oriented and macro-causal in the conceptual apparatus of the idealizational theory of science.

Let us suppose that a researcher wants to explain why magnitude $F$ defined on two objects, $O_{1}$ and $O_{2}$, adopted value $n$. Before the researcher chooses a comparative strategy he/she preliminarily delineates the object of the search. Based on the assumed ontological perspective, in the first stage of constructing a theory, the

156 Skocpol, Somers, “The Uses of Comparative History," p. 183.

157 Skocpol, Somers, “The Uses of Comparative History," p. 183.

158 Theda Skocpol, States and Social Revolutions (Cambrigde: Cambridge University Press, 1979), p. 39. On methodological discussion on Skocpol's book, see: Krzysztof Brzechczyn, "Strategies of Comparative Analysis in Historical Comparative Sociology: An Attempt at an Explication within the Conceptual Framework of the Idealizational Theory of Science," in: Idealization XIV: Models in Science eds. Giacomo Borbone and Krzysztof Brzechczyn (Leiden- Boston: Brill/Rodopi, 2016), pp. 187-191.

159 Theda Skocpol, "Analysing Causal Configuration in History: a Rejoinder to Nichols," Comparative Social Research, Vol. 9 (1986), p. 190. 
researcher determines what factors influence the studied magnitude $F$ and what factors have no impact on it. In the second stage of the construction of a theory the researcher delineates, based on assumed theoretical perspective, what types of factors can be the principal factors for the studied phenomenon. After a pool of the principal factors has been determined, the researchers states a hypothesis about whether magnitude $F$ defined on two objects belongs to one or to two $F$-genera, i.e. if it is subject to the influence of one or of two different principal factors.

Let us illustrate it in a more detailed fashion. Set $U$ of all objects with the magnitude $F$ makes the universe of a given magnitude. In this universe, one may single out certain subsets $Z_{A}, \ldots, Z_{N}$. These subsets are named $F$-species. The sum of $F$-species possessing this same primary factor forms $F$-genus, or generic type $F$ of a given magnitude in its defined scope. Thus, $F$-genera differ among themselves with the respect to the distinguished primary factor, whereas $F$-species which belong to the given $F$-kind differ with respect to secondary factors. A given $F$-genus is then a sum of those $F$-species, which share the same primary factor.

If the researcher concludes that magnitude $F$ defined on two objects, $O_{1}$ and $\mathrm{O}_{2}$, belongs to two separate $F$-genera, then the contrast-oriented comparative method will be used. If the researcher concludes that it belongs to one $F$-genus, then the parallel comparative method will be used.

Let us take a closer look. The scientist has determined a pool of principal factors for the magnitude $F$ on the two objects $O_{1}$ and $O_{2}$. These include: $A, B$, $C, D, E, G, H, I, J$. Second, he/she has established that the magnitude $F$ on the two objects $O_{1}$ and $O_{2}$ belongs to two separate $F$-genera and he/she has decided to implement the contrast-oriented comparative method. The pool of principal factors present in the essential structure of the magnitude $F$ on the object $O_{1}$ comprises of: $A, B, C, D, E, G$, and the pool of principal factors present in the essential structure of the magnitude $F$ ascertained on the object $\mathrm{O}_{2}$ includes the following factors: $A, B, \mathrm{C}, H, I, J$.

$$
\begin{aligned}
& O_{1}: A, B, C, \boldsymbol{D}, \boldsymbol{E}, \boldsymbol{G} \\
& O_{2}: A, B, C, \boldsymbol{H}, \boldsymbol{I}, \boldsymbol{J}
\end{aligned}
$$

Factors $A, B$ and $C$ will be termed common factors for the magnitude $F$ defined on both objects, and factors $D, E, G$ and $H, I, J$ are particular factors for the magnitude $F$. On the force of the made earlier decisions, every common factor is a secondary factor for the magnitude $F$. The adopted research hypothesis, hence, makes the researcher to search for principal factors for the magnitude $F$ among the particular factors. In the case presented above, the possible principal factors for the magnitude $F$ on the object $O_{1}$ can be factors $D, E$ or $G$, and on the object $\mathrm{O}_{2-}$ factors $H, I$ or $J$. Nevertheless, it should be emphasized that not every 
particular factor can be a principal factor for the magnitude $F$ established on a given object. Such factors may include both secondary factors for the magnitude $F$ (that are principal factors for the magnitude $F$ in another scope of the magnitude) and principal factors for the magnitude $F$ in the studied range. All the compared determinants belong to a pool of principal factors distinguished with the theoretical assumptions adopted by the researcher.

This is, then, the cognitive effectiveness of the contrast-oriented method in light of the offered explication. It allows us to narrow down of the pool of factors that includes the principal factors. The method turns out to be a useful heuristic tool in the second stage of constructing the theory after the initial division of factors into essential and inessential, and when we accept a particular theoretical perspective determining what type of factors are to be principal ones. On account of the comparative method, we can differentiate from the pool of principal factors, the factors principal in the given scope of the magnitude $F$.

If the researcher decides that the magnitude $F$ ascertained on the two objects $O_{1}$ and $O_{2}$ belongs to two $F$-species creating one $F$-genus, he/she begins to search for one principal factor, and not for two separate principal factors. He/she then implements a parallel comparative strategy. There are two sets of factors influencing the magnitude $F$ on the two objects:

$$
\begin{aligned}
& O_{1}: A, B, C, D, E, G \\
& O_{2}: A, B, C, H, I, J
\end{aligned}
$$

On the force of the adopted theoretical assumptions, a researcher searchers for a principal factor among the factors common for the magnitude $F$ on both objects. In the example under analysis, they include factors $A, B$ and $C$. Differently, the particular factors could be the secondary determinants for the magnitude $F$ in the range under investigation (however, they are the principal factors in other ranges and, hence, belong to a pool of principal factors distinguished with theoretical assumptions). The factors influencing the magnitude $F$ on the object $O_{1}$ include: $D, E$ and $G$, and the factors influencing the magnitude $F$ on the object $\mathrm{O}_{2}$ include: $\mathrm{H}, \mathrm{I}$ and $\mathrm{J}$.

Once more, a parallel comparative analysis narrows down only the pool of factors where principal factors "hide" in a particular range of the magnitude $F$. The adopted theory guides further hierarchy of factors and formulation of dependencies between the magnitude $F$ and the influencing principal factors.

Afterwards, the researcher implements a macro-causal comparative method that is a combination of the parallel and the contrast-oriented method in order to further narrow down the pool of factors that could include the principal factors. In the first stage, he/she assumes that the magnitude $F$ ascertained on the two 
objects $O_{1}$ and $O_{2}$ belongs to the same $F$-genus. He/she implements the parallel comparative method to uncover the principal factor:

$$
\begin{aligned}
& O_{1}: \boldsymbol{A}, \boldsymbol{B}, \boldsymbol{C}, D, E, G \\
& O_{2}: \boldsymbol{A}, \boldsymbol{B}, \boldsymbol{C}, H, I, J
\end{aligned}
$$

The implementation of the parallel comparative method indicates that the principal factor "hides" within factors $A, B$ or $C$. In order to further narrow down the pool of factors, the scientist implements the contrast-oriented comparative method. He/she compares the essential structure of the magnitude $F$ ascertained on the objects $O_{1}$ and $O_{2}$ with the essential structure of the magnitude $F$ on the object $\mathrm{O}_{3}$. The process of contrasting has to meet the following two conditions:

- the magnitude $F$ on the object $O_{3}$ has to adopt a value other than value $n$ adopted by the magnitude $F$ on the two objects $O_{1}$ and $O_{2}$;

- the magnitude $\mathrm{F}$ on the object $\mathrm{O}_{3}$ has to have an essential structure adequately close to the magnitude $F$ ascertained on the two objects $O_{1}$ and $O_{2}$.

This can be symbolically demonstrated in the following way:

$$
\begin{aligned}
& O_{1}: \boldsymbol{A}, \boldsymbol{B}, \boldsymbol{C}, D, E, G \\
& O_{2}: \boldsymbol{A}, \boldsymbol{B}, \boldsymbol{C}, H, I, J \\
& O_{3}: \boldsymbol{C}, D, E, G, I, J
\end{aligned}
$$

Factors $A, B$ and $C$ are the common factors for the magnitude $F$ on the two objects $O_{1}$ and $O_{2}$. Therefore, the principal factor(s) should be searched from among them. A test case analysis: $F$ on the object $O_{3}$ adopts a different value than the value $n$ ("negative case") despite a "close similarity" of the essential structure of $F$ ascertained on the object $O_{3}$ to the essential structure of $F$ on the objects $O_{1}$ and $\mathrm{O}_{2}$. In the essential structure of the "negative case" there is a factor $C$ that was predominantly established as principal and a number of secondary factors $(E, G$, $I, J)$. However, two other factors considered as principal: $A$ and $B$ are not present. As the magnitude $F$ adopted a value other than the value $n$, we can assume that the absence of $A$ and $B$ was decisive in this case.

The scientist continues the comparison with the aim to determine which of the two factors, $A$ or $B$, is the principal factor. He/she is searching for another control case: the magnitude $F$ ascertained on the object $O_{4}$ and adopting the value $m$ other than the value $n$, but having a adequately similar essential structure to the magnitude $F$ on the previously analyzed objects. Symbolically, this can be demonstrated in the following way:

$$
\begin{aligned}
& O_{1}: \boldsymbol{A}, \boldsymbol{B}, \boldsymbol{C}, D, E, G \\
& O_{2}: \boldsymbol{A}, \boldsymbol{B}, \boldsymbol{C}, H, I, J
\end{aligned}
$$




$$
\begin{aligned}
& \boldsymbol{O}_{3}: \boldsymbol{C}, D, E, G, I, J \\
& \boldsymbol{O}_{4}: \boldsymbol{B}, D, E, G, H, J
\end{aligned}
$$

In the essential structure of the second "negative case" the factor $B$ is determined as principal. However, other principal factors, $A$ and $C$, are absent. As in the first control case the factors $A$ and $B$ were absent from the essential structure of the magnitude $F$, and now $A$ and $C$ are absent, we can assume that the factor $A$ is the factor most influential for the magnitude $F$ adopting value $n$ on the objects $O_{1}$ and $O_{2}$. If the factor $A$ was present in the essential structure of the magnitude $F$, it has adopted the value $n$; if the factor $A$ was absent, the magnitude $F$ has adopted an intensity other than $n$.

It appears that the macro-causal comparative method is more effective than the other two methods due to the fact that it is capable of additionally narrowing down the pool of factors that "hide" the principal factors of the phenomenon under investigation.

However, the comparative method does not consist in the implementation of pure induction, but it becomes useful only when the researcher adopts a particular ontological perspective, which allows him/her to differentiate between the factors exerting impact on the studied phenomenon from those that do not exert impact, and a particular theoretical perspective allowing him/her to determine the type of sought principal factors. If the scientist assumes that the cases under research belong to different types, he/she implements a contrast-oriented method and searches for the principal determinants among particular factors present in the essential structures of the cases under comparison. If the researcher assumes that the cases under comparison belong to the same type, he/she implements a parallel method and searches for the principal factors among the common factors present in the essential structures of cases under comparison. To conclude: a comparative method proves useful, when the scientist guided by the previously adopted ontological and theoretical assumptions, knows a priori what he/she is comparing and why.

However, according to the above-presented approach, the effectiveness of the comparative method depends on a number of hidden theoretical assumptions that are seldom met or not met in the social and historical sciences.

First, the historical sciences very rarely offer separate research cases that differ from each other by the lack of only one of the factors under investigation. Second, a simplified assumption is adopted that the influence of the factors exerted on the magnitude under study depends on the intensity adopted by the determining factors. Third, an assumption is adopted that the acting factors do not interact with each other. ${ }^{160}$ Finally, an assumption is adopted that the cases under analysis

160 For an explication of the interaction of factors in the conceptual apparatus of ITS, see: Jerzy Brzeziński, “Interaction, Essential Structure, Experiment,” Poznań Studies 
are independent from each other. ${ }^{161}$ The above-listed circumstances are usually rarely met in the historical sciences, and they limit the range of implementation of the comparative method or influence its reliability.

\section{The Method of Modeling in the Economic History}

\subsection{Classification of Economic Models}

The methods of idealization and gradual concretization have proved useful in the historical sciences predominantly in the domain of the economic history. The method of modeling is a research tool principally implemented by historians associated with the Marxian tradition and the paradigm of the New Economic History. ${ }^{162}$ The economic models developed by the economic historians can be

in the Philosophy of the Sciences and the Humanities, Vol. 1 (1975), pp. 43-58, and the following chapter of the present book.

161 Skocpol has introduced this assumption with reference to the French, Russian and Chinese revolution (Skocpol, States and Social Revolutions, p. 39). It is naturally a contra-factual assumption, as the French revolution of 1789 has influenced at least the ideals of the further 19th-century revolutions on the European continent, and the Chinese revolution was modelled on the Bolshevik revolution. For a full reconstruction of Skocpol's methodological and theoretical assumptions of the concept of revolution, see: Krzysztof Brzechczyn, "Rozwój teorii rewolucji w socjologii historycznoporównawczej. Próba analizy metodologicznej," in: O rewolucji. Obrazy radykalnej zmiany społecznej, eds. Krzysztof Brzechczyn and Marek Nowak (Poznań: Wyd. Nauk. IF UAM, 2007), pp. 37-64; Krzysztof Brzechczyn, "Zwycięska rewolucja i przegrana modernizacja. Próba parafrazy teorii rewolucji społecznych Thedy Skocpol w aparaturze pojęciowej nie-Marksowskiego materializmu historycznego," in: Jednostka w układzie społecznym. Próba teoretycznej konceptualizacji, eds. Krzysztof Brzechczyn, Mieszko Ciesielski and Eliza Karczyńska (Poznań: WN WNS UAM, 2013), pp. 223-252; Krzysztof Brzechczyn, "Miejsce metody porównawczej w teorii rewolucji Thedy Skocpol. Próba eksplikacji w aparaturze pojęciowej idealizacyjnej teorii nauki," Filozofia Nauki, Vol. 24, No. 4 (2016), pp. 49-72; Brzechczyn, "Strategies of Comparative Analysis," pp. 184-201.

162 According to Jan Pomorski, the models developed by authors from the circle of the New Economic History are interpreted in a realistic way. He also presents a procedure of modeling in line with this paradigm. In the first stage, the idealizing assumptions (or counter-factual) and realistic assumptions are put forward. Afterwards, "the prime functional dependency of an analysed structure determining the other magnitudes" is established, see: Jan Pomorski, Paradygmat "New Economic History." Studium z teorii rozwoju nauki historycznej (Lublin: Wyd. UMCS, 1985), p. 127. In consequence, the basic economic categories, which are in direct connection with the analyzed functional dependency are distinguished. In the further stadium of the modeling procedure, a 
classified with reference to a number of aspects. Jerzy Topolski, for instance, divides the economic models according to their methodological status into models comprehended from an instrumental or a realistic perspective. According to Topolski, in a methodological sense, a model is:

a simplified image of a given fragment of the reality (a set of statements concerning it) that facilitates the "capturing" of the essential features of the fragment, by disregarding a large or small number of secondary factors that distort the manifestation of the "essential" features (and tendencies). As can be easily seen, this is a realistic interpretation of a model (implemented e.g. by Marx in Capital) perceived as an (isomorphic) "image" of the reality, in contrast to a model comprehended in an instrumental way, uniquely as a research tool that is rejected after completing a task (like Weber's ideal types). Therefore, a model in a realistic interpretation has an objective reference and an instrumental interpretation does not include such reference, or the reference is deformed. ${ }^{163}$

Topolski also offers an alternative classification. He divides the models present in the historical works into static and dynamic with reference to the method of conceptualization of the historical reality under investigation. A static model or a model comprehended in a narrower sense, according to Topolski's terminology, comprises a set of statements describing a historical reality stripped of secondary features and phenomena. In such case, a procedure of simplification of the reality is also a model. A dynamic model consists in an idealization of the fragment of reality under study and in an analysis of the changes that the - accurately simplified - phenomena are subject to.

The present demonstration of the implementation of the method of modeling in the economic history will employ yet another classification of the economic models. Models can be divided into general, local and global with reference to the range of the phenomena under investigation. The general models consider the functioning of particular social units, such as a feudal system. Evsey D. Domar's explanation of the genesis of the exacerbated serfdom in Eastern Europe and Witold Kula's theory of the feudal system are examples of such a model.

Differently, local models aim to explain more particular phenomena by adopting a general theory. The economic model of the Greater Poland Region in the 18th century developed by Jerzy Topolski - which adopts Witold Kula's

dynamic of the researched structure is analysed and prognoses are formulated concerning its future states. Finally, an operationalization of the variables of the model is conducted, and theses are verified against an empirical material, see: Pomorski, Paradygmat, pp. 125-132

163 Jerzy Topolski, Marksizm i historia (Warszawa: PWN, 1977), p. 134. 
theory of the feudal system to explain the regional distinctiveness of this part of Poland - is an example of such a model.

We could also differentiate global models that explain the phenomena under investigation in an international context. The model of intercontinental commerce constructed by Frédéric Mauro will serve as an example of this type of model in the present book.

The idealizational theory includes realistic assumptions, idealizing assumptions, statements and particular between-model correlations. Realistic assumptions determine the range of application of a given theory. Idealizing assumptions disregard a number of factors perceived as less essential. Afterwards, a scientist derives from the above-mentioned assumptions a number of statements that describe the dependencies of the phenomena under study from the factors perceived as principal. In the subsequent conceptualizations, the assumptions are removed and the initial statements are corrected. The relations of concretization or of approximation occur between the separate models of a given theory. This can be demonstrated in the following way:

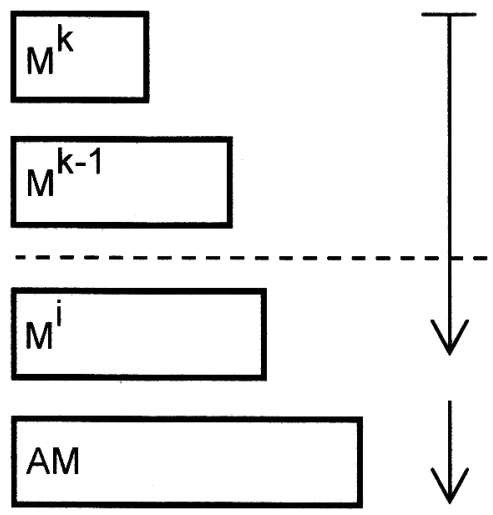

Fig. 3: Structure of the idealizational theory of science. Explanations: $M^{1-}$ the next model of the idealizational theory with an index indicating the number of idealizing assumptions; $A M$ - approximation of the model; $\mapsto$ relation of concretization; $\rightarrow$ relation of approximation.

In the following part of this chapter, I will reconstruct particular examples of models in line with the above-presented structure of the idealizational theory. 


\subsection{Evsey Domar's Theory of the Rise of Exacerbated Serfdom}

Evsey D. Domar developed a model explaining the presence of exacerbated serfdom in Eastern Europe. He put forward a theory with realistic assumptions referring to 16th-century Russia and the Polish-Lithuanian Commonwealth. The basic model is founded on eight simplifying assumptions ${ }^{164}$ :

$\left(a_{1}\right)$ the only production factors are work and land (the influence of capital, management methods and other factors is disregarded);

$\left(a_{2}\right)$ the quality of soil and the localization of the agricultural land does not vary; $\left(a_{3}\right)$ the level of income is not influenced by the labor force hired to cultivate the land;

$\left(a_{4}\right)$ the productivity of the hired labor force does not vary;

$\left(a_{5}\right)$ the competition between employers causes an increase of salary of hired labor force to a level when the cultivation of land does not bring any income; $\left(a_{6}\right)$ the productivity of labor force is constant;

$\left(a_{7}\right)$ a political authority does not interfere with free trade of land;

$\left(\mathrm{a}_{8}\right)$ a political authority does not interfere with free labor market.

In this set of simplifying assumptions, the idealizing assumptions are: $\left(\mathrm{a}_{1-5}\right)$, the stabilizing assumptions: $\left(\mathrm{a}_{6}\right)$ and the quasi-idealizing assumptions: $\left(\mathrm{a}_{7-8}\right)$.

The circumstances of the model I based on the idealizing assumptions $\left(\mathrm{a}_{1-8}\right)$ precludes the evolution of the economic classes, because

[i]n the absence of specific governmental action [. . . the country will consist of familysize farms because hired labor, in any form, will be either unavailable or unprofitable: the wage of a hired man or the income of a tenant will have to be at least equal to what he can make on his own farm. ${ }^{165}$

Therefore, in the highly idealized circumstances of the first model, a class of proprietors does not develop. A social structure of such society comprises of a political authority and a free peasantry. It does not comprise of economic classes.

As the first model does not adhere to the empirical reality, Domar gradually removes the initially adopted simplifying assumptions. First, he removes the assumptions $\mathrm{a}_{1}$ and $\mathrm{a}_{2}$. He investigates the influence of capital (accountancy costs, food, grain, livestock, etc.) and the influence of management on the process of administration, and assumes that quality and location of the agricultural

164 Evsey D. Domar, "The Causes of Slavery or Serfdom: A Hypothesis," The Journal of Economic History, No. 30 (1970), p. 19.

165 Domar, “The Causes of Slavery," p. 19. 
land varies. The process of class diversification can begin in the circumstances more adhere to reality, as the "[o]wners of capital, of superior skill and of betterthan-average land will now be able to pay hired man his due (or to use a tenant) and still obtain a surplus."166

However, in a situation when authorities refrain from interfering into the process of administration, the advantage of the nonworking class of proprietors developed under such circumstances is negligible, as "so long as agricultural skills can be easily acquired, the amount of capital for starting a farm is small, and the per capita income is relatively high (because of the ample supply of land) a good worker should be able to save or borrow and start on his own in time."167

In the circumstances of the second model, the economic structure of the rural areas changes insignificantly, since " $[\mathrm{m}]$ ost of the farms will still be more or less family-size, with an estate using hired labor (tenants) here and there in areas of unusually good (in fertility and/or location) land, or specializing in activities requiring higher-than-average capital intensity, or skilful management." ${ }^{\prime 68}$

As a result, in the second model that meets the assumptions $\left(\mathrm{a}_{3.8}\right)$, develops a class of proprietors, however, this social category does not have an advantage in the socio-economic structure. In the third model, Domar removes the assumption $\mathrm{a}_{7}$ that authorities do not interfere with the free trade of land: "Suppose now that the government decides to create, or at least to facilitate the creation, of a non-working class of agricultural proprietors." ${ }^{169}$

In consequence of the interference of a political authority into the economic life, the nonworking class of proprietors is granted an exclusive right of ownership of land. For now, the government intervenes into the free trade of land but not into the free labor market. The intervention of a political authority strengthens the social position of the class of proprietors. Nonetheless, the situation of proprietors slightly improves. As Domar observes, in the circumstances of shortage of workforce, the competition between proprietors causes an increase in salary of the paid labor to the level when only a small producer surplus is achieved.

The fourth model brings a real change in the relations between economic classes, when political authorities intervene into the labor market. In this model, the government acts in the interest of proprietors and forbids paid labor to

166 Domar, “The Causes of Slavery," p. 20.

167 Domar, “The Causes of Slavery," p. 20.

168 Domar, “The Causes of Slavery," p. 20.

169 Domar, “The Causes of Slavery, p. 20. 
change the place of residence and work. Only then "with labor tied to land or to the owner, competition among employers ceases. Now the employer can derive a rent, not from his land, but from his peasants by appropriating all or most of their income above some subsistence level." ${ }^{170}$

Exacerbated serfdom occurs in consequence of the deficiency of workforce and the interference of a political authority supporting the nonworking class of proprietors. Hence, this social layer develops in reaction to the monopolization of the trade of land or labor market. Only now the thesis of the first model becomes inapplicable - in the society under investigation, there develops a class of proprietors that gains a social advantage in the socio-economic structure. Domar concludes his study with a statement that any two out of the three elements of the economic structure - the free trade of land, the free labor market and the nonworking class of proprietors - can coexist, but not three, as the complete monopolization of the economic life can take place on behalf of a political authority that supports selected social groups to the detriment of other.

Domar approximates the theses of the fourth model to the historical reality of Russia and the Polish-Lithuanian Commonwealth. In my reconstruction, I will demonstrate an approximation of a model implemented with reference to Russia in more detailed way. Domar rests on Vasily Kluchevsky's book A History of Russia and argues that in the 16th-century Russia, "[t]he scarce factor of production was not land but labor. Hence it was the ownership of peasants and not of land that could yield an income."171

The author claims that until 1550 Russian peasants had enjoyed personal freedom and the country was populated enough population not to be externally endangered. However, in the century that followed, wars caused depopulation. Depopulation and the interference of the state that supported the class of landed gentry allowed for an introduction of exacerbated serfdom: "Thus both ingredients for the evolution of serfdom - a high land/labor ratio and the government's determination to create a large class of servitors - were present (in Russia)." ${ }^{\prime 17}$

The secondary factors disregarded in the modeling investigation that influenced the evolution of the second serfdom in Russia included: the decay of boyars who competed with the landed gentry over peasantry, the influence of the state that opposed the peasant movements, concerned about the regular

170 Domar, “The Causes of Slavery," p. 30.

171 Domar, "The Causes of Slavery," p. 19.

172 Domar, "The Causes of Slavery," p. 25. 
collection of taxes, and the presence of the peasant communities that opposed the migration of workforce.

Domar also discusses a case contradicting the thesis of the model prima facie. In Western Europe of the mid-14th century, a plague caused a significant depopulation. ${ }^{173}$ He ponders on why it did not lead to a secondary exacerbation of serfdom. Domar explains the situation with secondary factors omitted by him in the developed models of the theory. The plague did affect all proprietors equally. As a result, they did not unite. Some of them wanted to limit the freedom of the peasants, and others did not. Additionally, the nature of production - the wool industry requiring qualified workforce - resulted in the fact that serfdom was an ineffective system. The above-mentioned two factors outweighed the tendency to introduce exacerbated serfdom in the circumstances of the deficiency of workforce in Western Europe.

Let us now investigate which type of the idealizational theory is applicable to Domar's model. A certain peculiarity of this theory is the simultaneous removal of two simplifying assumptions and the simultaneous introduction of a concretized model of two secondary factors (i.e. a transfer from model I to model II). Additionally, the theory under study has a linear structure - every new factor is introduced into the latest concretized version of the model. The structure of the theory can be demonstrated in the following way:

$$
M^{8} \rightarrow M^{6} \rightarrow M^{5} \rightarrow M^{4} \Rightarrow A M
$$

Key: $M^{\mathrm{i}}$ - the next model of the theory with the index indicating the number of simplifying assumptions; $A M$ - approximation of the model; $\rightarrow$ - relation of concretization; => - relation of approximation.

\subsection{Witold Kula's Theory of the Feudal System in Poland}

Witold Kula's An Economic Theory of the Feudal System is a classic Polish historiographic opus that applies the method of modeling to historical analysis. Kula's theory is set to explain the functioning of a manorial-serf system in Poland between the 16th and the 18th centuries. By defining the range of validity of his theory is the above way, Kula ponders on the application of its statements to the borderland territories, such as Pomerania - the only region where peasants had direct contact with the global market, and Ukraine - the region almost completely cut off from contact with foreign markets, and the borderline ranges: the 1 st half of the 16 th century and the 2 nd half of the 18 th century. Kula

173 Domar, "The Causes of Slavery," p. 26 and further. 
also poses the question about the range of application of the statements of his theory to other historical societies - i.e. Hungary and Russia - that meet the simplified assumptions that constitute the foundation of his theory of feudal system. Kula develops a basic model of feudal system based on the following quasiidealizing assumptions, in order to investigate the mechanisms of functioning of the Polish feudal economy:

(1) the overwhelming dominance of agriculture in the country's economy; (2) the fact that land is not a commodity, primarily because only the nobility can own it, but also because the rate of interest on loans is higher than the yield from landed property; (3) the division of all the forces of agricultural production solely between the village and the lord's demesne; (4) the existence of actual institutional barriers which limit social and geographical mobility, above all for peasants (serfdom); (5) the obligation on all peasants to pay most of their rent in the form of labor power (corvée); (6) the fact that industrial and artisan activities are carried out within the confines of the large landed estates or the guilds; (7) the absence of juridical restrictions on the liberty of the nobility in the economic area; (8) a strong tendency among the nobility towards consumption luxury products (a tendency conditioned by the characteristics of the socio-economic system); (9) the existence, not far from Poland, of economically more advanced countries at a distance accessible by the means of transportation; (10) the absence of all state intervention in economic life (even in form of protectionist custom duties). ${ }^{174}$

Kula implicitly adopts two more assumptions that will be removed in the course of further analysis:

$\left(a_{11}\right)$ fluctuation of harvest does not influence the economic regularities; $\left(a_{12}\right)$ the influence of changes of terms of trade are not taken into consideration.

Kula formulates statements concerning the maintenance of the manorial estate, a peasant farm and a craftsman workshop organized in a guild, based on the abovelisted assumptions. A manorial-serf system is a dual sector economy: it includes a market sector and a natural economy. This significantly influences a calculation of the producer that notably varies from a calculation conducted by a capitalist who operates in the circumstances of a free market, because in the feudal economy:

(1) the producer makes his calculations according to criteria in kind, 2) market prices do not serve as a yardstick for elements that enter into production (because in general the prices inflate their value), nor for what is produced (3) the producer generally does not react to the incentives of market (an increase or decrease in prices). ${ }^{175}$

174 Witold Kula, An Economic Theory of the Feudal System. Towards a Model of Polish Economy, 1500-1800 (London: NLB, 1976), p. 26. For an original reconstruction of the theory, see: Nowak, Zasady marksistowskiej filozofii nauki, pp. 212-213.

175 Kula, An Economic Theory, pp. 42-43. 
According to a calculation conducted by a typical manor owner, the profit is not the difference between income received from selling and the production costs calculated at market prices. A typical nobleman, who has at his command a "free" workforce of peasants under serfdom, limits the amount of purchase and fabricates in his own manorial estate all ingredients required for production or objects of consumption. This way, he profits from selling an arbitrary amount of grain for an arbitrary price, and can allocate this profit for the purchase of luxury goods. According to Kula, the amount of the sale of grain did not depend on price, but on the fluctuation of the level of harvest. Hence, a feudal farm was independent from economic fluctuations. In the circumstances of a manorialserf economy,

The demesne carries out essentially an extensive form of farming. The harvest that it brings in is a function of the surface area under cultivation. If the surface area of the land owned by the lord was greater than the area cultivated by the serfs, a portion of the land remained uncultivated since the extensiveness of the farming depended on the number of serfs. ${ }^{176}$

Kula distinguishes two opposite social tendencies present in a manorial-serf system comprehended in the above way. The first is the tendency of the manorial estate to reduce the size of the peasant farm below the level of "a consumptionreproductive parcel" - a parcel covering an area sufficient for simple reproduction and sustaining livestock. Restricting the area of peasant farms lead to cutting off contact between peasants and the market.

The limit of exploitation of peasantry was, in Kula's terms, "a physiological limit" - the amount of labor that could have been provided by the peasantry without ruining it. However, in practice, the physiological limit was never reached, as the exploitation of peasantry would first meet a "social limit." The latter was an amount of service that could have been obtained from the peasants, in the circumstances of the given level of class opposition and the effectiveness of labor. Kula considers also a "technological limit" consisting in the number of working animals at disposal, because peasants paid quitrent with the use of own livestock. It appears that this third limit determined the upper limit of agricultural production of the country.

Another counter tendency was the aspiration of the peasant farms to maintain contact with the market by all means. When a manorial estate did not succeed in cutting the peasant farm off from the trade contacts with a town, it adapted to the situation and attempted to extract money from the country by using the

176 Kula, An Economic Theory, p. 46. 
propination laws - compulsory purchase of alcohol and other everyday-use products (salt) by peasants. This situation resulted in a growing self-sufficiency and economic isolation of vast land properties. This, in turn, reinforced the trend to naturalize goods because:

Every demesne attempted not to purchase the indispensable things, but instead to produce them from their own resources, without spending money. [...] Production was to maintain itself on its own, and the basic elements consumed by the owner's family and his force equally so. All the liquid money derived from the sale of surplus production - which was to be as great as possible - was to be set aside for the purchase of luxury gods. ${ }^{177}$

Kula describes it as a tendency toward maximal naturalization intended at maximal commoditization.

A peasant farm that attempted to maintain contact with the market at all means was emerged into the circumstances of a natural economy even more. This tendency was contrasted with the tendency of a manorial estate to reduce the economic independency of peasantry. In the circumstances of a manorialserf system, peasants were able to increase production for the market by illegally expanding the area of the cultivated land, conducting more intense cultivation, malnutrition of cattle serving the manor, directing the surplus of the workforce of a peasant farm to gardening, husbandry of porcine animals and poultry, engaging in craft and uttermost limitation of consumption.

Another factor forcing peasants to establish at least limited contact with the market was the social-political system that pressured them to pay taxes and other cash benefits and lead to a phenomenon of the "obligation to commercialize:"

The peasant is compelled to sell in order to obtain the money he needs to meet these financial obligations and not lose his plot. His reaction to the incentives of market is diametrically opposed to what bourgeois economic science would expect: if prices go up, he sells less, and if they go down he has to sell more. The fiscal burdens to which he is subject are basically fixed; therefore the amount sold (often at the expense of what is available for his own personal consumption) is inversely proportional to the price level. It often happens that a high level of prices brings about a relative return to "natural production" of such plots and vice versa. ${ }^{178}$

Apart from analyzing the peasant and manor sector of the economy, Kula also analyses the economic behavior of a craft workshop organized in a guild. A typical craftsman calculates like a monopolist operating on a narrow market. As an

177 Kula, An Economic Theory, p. 141.

178 Kula, An Economic Theory, p. 43. 
organization of producers, a craft guild dictated the prices and the production size. The activity of a craft corporation was directed at

[a]ttempt to set a "monopoly price," i.e. to limit the quantity of goods produced and to raise the price so as to obtain the maximum overall income. The limit to which the price could be raised was established the level of actual demand. The equitable distribution of profits brought about by the market monopoly that was maintained by the guilds was to be guaranteed by the regulation which prevented competition. ${ }^{179}$

The entire system of guild regulations was set so that production would not exceed consumption. Only then, a "market of sellers" was in force and a guild could fully benefit from its monopolistic position.

In the model II, Kula reduces the assumption $\left(\mathrm{a}_{11}\right)$ eliminating the influence of the fluctuation of harvest on the behavior of the economic subjects. Hence, this model examines the influence of agricultural failure and harvest. It allows investigating the behavior of economic entities in a short-term perspective. Harvest would cause a decrease in prices of agricultural products and failed harvest would cause an increase. The years of good crop reinforced the tendency expressed by the manorial estate to reduce peasant parcels to the size of consumption-reproductive parcels. This tendency was caused by a "nonmarket" response to the market stimuli. The increase of supply of grain caused a decrease of its price. In order to maintain income on a constant level, a manor owner had to sell more grain for a lower price. The only way to increase production, under the circumstances of a technological stagnation, was to increase the area of cultivated land. In consequence, according to the internal logic of the model, an extensive increase of production of a manorial estate was achieved by assuming the peasant land or by settlement. In the years of failed harvest the tendency was opposite. In the years of failed harvest the price of gain would increase and supply would decrease, therefore, a manor owner, in order to increase profit was forced to reduce the production costs, hence, produce as many goods as possible by himself. This resulted in increased burdening of peasants and the naturalization of economy.

Subsequently, Kula moves on to discuss the influence of harvest fluctuation on peasant farms. During the so-called "good years," in order to maintain a constant level of income, peasants had to sell more grain. On the one hand, the years of failed harvest would cause an intensification of trade contacts of a peasant farm but, on the other hand, would reinforce the tendency of the manorial estate to reduce the farmland. During the "lean years," in order to maintain

179 Kula, An Economic Theory, p. 76. 
the same level of income as in the previous years, peasants would sell less grain. During the bad years, after selling the necessary amount of grain and acquiring profit sufficient to pay taxes and satisfy their consumption needs, peasants would transfer the costs of maintenance of their farm onto the manorial estate - i.e. they would cease taking care of draught animals used to pay quitrent (quitrent in livestock). During the years of failed harvest the intensity of trade contacts of peasants decreased but, simultaneously, the tendency to reduce the area of peasant farms would disappear.

In the further part of his study Kula discusses the influence of harvest fluctuation on craft production. A typical craft workshop benefited from harvest and low prices of grain because:

1) the price of raw materials goes down; 2) the cost of labor goes down (since an important part of the remuneration paid to auxiliary workers, journeymen, and apprentices was paid in kind); 3) actual overall demand increases, making possible the full utilization of the shops' production capacity; 4) demand increases faster than supply, making possible the actual operation of a "seller's market." ${ }^{180}$

When the effective demand of people increased during harvest, the guild system counteracted against the decrease of prices on craft products. During the period of decreased effective demand caused by failed harvest and increased grain prices, the guild corporations counteracted against the decrease of prices on craft products by reducing the production size and incorporating the increased price of labor, the price of materials and the costs of supporting the master into the price of craft products. Afterwards, Kula approximates the above statements to the empirical reality. The object of approximation is the statement concerning the dependency between the fluctuation in harvest and the fluctuation in prices of agricultural products. Kula calculates grain prices and concludes: "in the basis of Polish source materials, it appears that such dependent relationship exists, but only to a limited extent." ${ }^{181}$ This is influenced by the selected method of calculation that blurs the correlation: the calculation is based on a calendar year, not on a harvest year, and the calculation is presented in nominal prices, not in the real prices. ${ }^{182}$ Additionally, the second model has excluded the following factors: "the effect of the export price, as well as export itself - not to mention the effect of phenomena which took place on the world market."183

180 Kula, An Economic Theory, pp. 76-77.

181 Kula, An Economic Theory, p. 83.

182 Kula, An Economic Theory, pp. 83 and 87.

183 Kula, An Economic Theory, p. 89. 
In model III, Kula removes the assumption $\left(\mathrm{a}_{12}\right)$ on the unchanging terms of trade and investigates a manorial-serf system in the long-term perspective. Kula characterizes it in the following way for the period under study:

(1) an increase in the price of products exported by the nobleman, primarily grains and particularly wheat; a very rapid increase at first (sixteenth century), then slower (from about 1660), and then after a brief decline at the end of the seventeenth century, a slow but virtually constant increase for all eighteenth century;

(2) a relative decline in the price of certain imported goods, due to the fact that the European powers were making better use of their overseas colonies (spice, sugar, etc.);

(3) slighter decline (but also unquestionable) in the price of another category of imported goods, as a result of the progress made in the sphere of technology and the organization of production (textiles, paper, iron, etc.). ${ }^{184}$

Terms of trade more beneficial to magnates caused an increase of the advantage of this social group over the middle nobility. On account of this, we are able to explain another trend present in a manorial-serf economy - the tendency to accumulate vast possessions. This trend reinforces the processes of neutralization and isolation of large properties of the basic model. Additionally, improved terms of selling grain in Gdańsk facilitated a retraction of magnates and the nobility from the internal market - it became more beneficial to purchase grain from the nobility and peasantry and to export it, instead of supplying the internal market for magnates. A substantial increase of profitability owed to selling grain abroad also sheds light on the reasons behind the stagnation of production the nobility ceased to introduce technological innovations because they did not cause a significant increase of income, in comparison to the organization of sale of grain. A manorial-serf system, nevertheless successfully burdened peasants with all costs of production. To conclude this part of his study, Kula puts forward the idea that Poland:

Was able to import a greater amount for the same quantity of commodities exported. This is, in appearance, a favourable situation, the opposite of the one in which countries exporting raw materials find themselves today (countries that are generally underdeveloped). In those countries the terms of trade have been worsening for the past century, exacerbating already existing economic difficulties. But here again we have an example, which shows how the economic situation of today's underdeveloped countries

184 Kula, An Economic Theory, pp. 119-120. 
is in many ways different from the situation in the preindustrial age, and how economic regularities operated differently then. The shifts in the terms of trade, which were apparently favourable to Poland, in reality undermined Polish economic development, although they brought great economic advantage to a single social stratum. Due to the concurrence of great world-wide changes, the Polish nobility, and particularly the upper nobility, found themselves in the position of rentiers, 'coupon clipping' and profiting from the process of economic retrogression in the country. ${ }^{185}$

Subsequently, Kula conducts an approximation of a number of theses from the third model to empirical reality. He determines a "shopping basket" for a magnate, a nobleman and a peasant, and calculates how the changing terms of trade impacted their purchasing power, in order to judge how the prices of grain on the global market influenced the economic situation of individual social classes. According to him, in the period between 1600 and 1750:

the overall real income - here too caeteris paribus, without taking into account increases in the area held, in returns, in commercialization, etc. - went up from 100 to 200 for the upper nobility, and from 100 to 142 for the lower nobility whereas for the peasantry it went down from 100 to $92.5 .^{186}$

Kula's theory of feudal system has a star structure. The most idealized model is based on the assumptions $\left(\mathrm{a}_{1-12}\right)$. Kula uses it to explain the behavior of a manorial estate of a nobleman, a peasant farm and a craft workshop. Afterwards, Kula waives the assumption $\left(\mathrm{a}_{11}\right)$ and investigates the influence of fluctuation of harvest on the code of conduct of a manorial estate of a nobleman, a peasant farm and a craftsmanship. Subsequently, the theses of the second model are subjected to approximation. Following that, Kula reinstates the removed assumption $\left(\mathrm{a}_{11}\right)$ and removes the assumption $\left(\mathrm{a}_{12}\right)$. In the third model he studies the influence of the changing terms of trade on the economic activity of a manorial estate. Again, the theses of model III are subjected to approximation. Hence, the graphic structure of Kula's theory of feudal system can be demonstrated in the following way:

$$
A M \Leftarrow M_{1}^{11} \leftarrow M^{12} \rightarrow M_{2}^{11} \Rightarrow A M
$$

Key: $M^{\mathrm{i}}$ - the next model of the theory with an index indicating the number of idealizing assumptions; $A M$ - approximation of the model; $\rightarrow-$ relation of concretization; $\Rightarrow$ - relation of approximation

The star structure of Kula's theory of feudal system has stirred a lot of criticism. The principal accusation against the theory was that there is no connection

185 Kula, An Economic Theory, p. 133.

186 Kula, An Economic Theory, p. 126. 
between the "short-term dynamics" (model II) and the "long-term dynamics" (model III) ${ }^{187}$ After the publication of An Economic Theory of the Feudal System a number of historians conducted source research of regional markets inspired by the theses of the model of feudal economy. ${ }^{188}$ The results of these investigations have partially confirmed some of the theses put forward by Kula (the correlation between harvest fluctuation and price of grain) and contradicted others (the thesis on reduction of the area of peasant plots).

\subsection{Jerzy Topolski's Model of Economy of Greater Poland}

Jerzy Topolski's economic model of Greater Poland is an example of a local model. ${ }^{189}$ Topolski adopted Kula's economic theory of the feudal system as a general concept. The models developed by Topolski and Kula are linked with a relation of territorial-chronological specification because, according to Topolski, some of Kula's assumptions were not met on the territory of Greater Poland in the 2 nd half of the 18th century. Therefore, the developmental regularities established by Kula with relation to Polish economy, that cannot be applied to the 18th-century Greater Poland have to be modified substantially. Hence, the relation of specification determines the range of validity of Topolski's model Greater Poland in the 2nd half of the 18th century.

Most importantly, Kula's assumption $\left(\mathrm{a}_{1}\right)$ on the "the overwhelming dominance of agriculture in the country's economy" cannot be applied to Greater Poland because in the 2 nd half of the 18th century the region was experiencing an intensive process of urbanization. Hence, as argued by Topolski,

it would be more appropriate to speak of an agricultural-industrial structure of the region with reference to Greater Poland. Before the second partition, the percentage of population living in towns was around $28 \%$ in Greater Poland, almost half of which lived in towns with a population of more than 2,500. Unlike towns in other regions of Poland, towns in Greater Poland were not so heavily agrarian in nature. Only $16 \%$ of

187 Cf. Jerzy Topolski, "Verification in Economic History," Studia Historiae Oeconomicae, Vol. 21 (1994), pp. 20-21. For a discussion of the reaction of academic critcisim to Kula's theory, see: Jacek Kochanowicz, “Teoria ekonomiczna... w oczach krytyków," in: Jerzy Kula, Teoria ekonomiczna ustroju feudalnego (Warszawa: Książka i Wiedza, 1983), pp. 247-270.

188 For a discussion of the results of papers inspired by Kula's theory, see also: Topolski, "The Development and the Crisis", pp. 136-141.

189 Jerzy Topolski, "The Economic Model of the Wielkopolska Region in the 18th Century," in: Idealization XIII: Modeling in History, ed. Krzysztof Brzechczyn (Amsterdam/ New York: Rodopi, 2009 [1977]), pp. 269-285. 
the overall population of Greater Poland's towns lived in agriculture, whereas the population involved in commerce and crafts accounted for ca. $70 \% .{ }^{190}$

Moreover, the assumption $\left(\mathrm{a}_{5}\right)$ from the theory of feudalism stating that "the obligation of all peasants to pay most of their rent in the form of labor power (corvee)" cannot be applied to Greater Poland because, as argued by Topolski, cash pension constituted a large contribution in the structure of peasant services. Topolski also removed the simplifying assumption $\left(\mathrm{a}_{9}\right)$ on the "the existence, not far from Poland, of economically more advanced countries at a distance accessible by the means of transportation." In the 2 nd half of the 18 th century, Greater Poland was neighboring Brandenburg and Pomerania, from which it was more economically developed - i.e. it had a positive trade balance. In consequence, the manorial production in this region was principally dedicated to the internal market, in contrast to Kula's model where it was dedicated to the external market.

The influence of the above-listed factors, disregarded by Kula in his model of the theory of Polish feudalism, caused a significant modification of the developmental regularities characteristic for the Polish economy in Greater Poland.

According the model put forward by Kula, the manorial estate refrained from investment almost completely, due to the fact that the costs of production were carried by the peasant economy functioning under the natural economy. As a result, every single income from selling grain abroad brought profit. The nobility in Greater Poland of the 18th century had different rules of economic proceeding, due to "a propensity to invest, that is, to increase the stock of the means of production in order to boost income, a trend which was alien by and large alien to the classical model." ${ }^{\prime 11}$

The direction of these investments depended on the regional specificity of Greater Poland, hence, the factors omitted by Kula, such as: substantial influence of the urban sector on the economy, absence of economically dominant countries and a relatively large contribution of rent into the general structure of peasant services. In consequence, the economic actions of the nobility resulted the following situation:

Both among the nobility and the peasants there emerged a type of mentality which may be described as contractual and which was alien to traditional feudalism. It resulted from the increasing number of arrangements between the landlord and the peasant that were based on contracts. This was true both for entire villages and for individual peasants (e.g. for the categories of tenants, contract workers, etc.). ${ }^{192}$

190 Topolski, “The Economic Model," p. 281.

191 Topolski, "The Economic Model," p. 277.

192 Topolski, “The Economic Model," p. 284. 
Afterwards, Topolski approximates the statements of the local model to the economic reality of Greater Poland. In the 18th century, the investment activity of the nobility in the region was manifested by the development of non-grain production, in the organization of settlement actions and in establishing a number of villages and little towns.

Under the non-grain production, the nobility of Greater Poland developed livestock breeding, fishing economy, exploitation of forests, gardening and production of alcoholic drinks. Sheep breeding was taking the principal place among animal husbandry. Prior to the third partition of Poland, in the years 1780-1790, there were around 6.5 million sheep in Poland - 1.3-1.4 million in Greater Poland. Following from this, $20 \%$ of sheep population that provided $650,000 \mathrm{~kg}$ of wool was located on the $4 \%$ of Polish territory. The noble manorial estates owned $2 / 3$ of the total sheep population.

The growth of sheep breeding depended from the demand of the textile industry that developed in $60 \%$ of towns in Greater Poland. ${ }^{193}$ The industry supported around $12 \%$ of population of the region. The wool from Greater Poland was also sold to the neighboring Silesian-Czech-Moravian textile center.

Another manifestation of the investment activities of the nobility was the settlement development. A colonization movement thrived in the region in the 18th century:

In total, during the 18th century around 800 new villages were settled, as a result of which the area of agricultural land increased by 140,000 hectares. The increase in the area under cultivation is estimated at $20 \%$ (after the havoc wreaked by the Great Northern War was offset). This kind of expansion of agricultural land cannot be found in other regions of the country. ${ }^{194}$

The number of rural settlements was growing and new towns were settled there were around 25 new towns established in the 18th century, mostly with a progressing textile production.

On the force of the conclusions presented by Jan Rutkowski, Topolski approximates the second thesis of the model to the empirical material - the spread of contractual relations between the manorial estate and the rural areas. The thesis is confirmed by a substantial percentage of quitrent peasants in Greater Poland - around $30 \%$, and a large percentage of landless peasants - $25 \%$, while the percentage of landless peasants in Mazovia and Podlachia was at $9 \%$, in Lesser Poland at $18 \%$, and on the Russian territories - $10 \%$.

193 Topolski, “The Economic Model,” p. 281

194 Topolski, “The Economic Model,” p. 279. 
A relation of chronological-territorial specification, hence, links Kula's general model to Topolski's local model. Topolski reduces a number of simplifying assumptions, determines the range of introduced factors and introduces amendments to the statements formulated by Kula. Subsequently, he approximates the modified statements to the historical reality. The structure of the relation linking the models can be graphically demonstrated in the following way:

$$
M^{12} \rightarrow M^{9} \Rightarrow A M
$$

Key: $M^{\mathrm{i}}$ - the next model of the theory with an index indicating the number of idealizing assumptions; $\rightarrow$ - relation of territorial-chronological specification; $\Rightarrow$ - relation of approximation; $A M$ - approximation of the model.

\subsection{Frédéric Mauro's Theory of Intercontinental Trade}

A global model can be discussed based on the model of intercontinental trade developed by Frédéric Mauro who investigates an intercontinental trade exchange during the period of commercial capitalism. Mauro determines realistic assumptions while assuming that the statements of his model are valid from the period of Renaissance until the Industrial Revolution, hence, for the period between 1500 and 1800 . The model is based on the following simplifying assumptions:

$\left(a_{1}\right)$ production control and the level of acquired profit is in the hands of the class of merchants, hence, the influence of the early-capitalistic bourgeoisie is omitted;

Mauro explains his assumptions in the following way:

In reality this pure system is confused with others; the medieval system based on the domain in the country and on artisanship in the towns, and also industrial capitalism in as much as this commercial capitalism has already experienced industrial prerevolutions. But the important thing is that the dominant, dynamic, progressive system should be that of commercial capitalism. This predominance, combined with mercantilist policies, produces economic régimes in which international trade is extremely important. ${ }^{195}$

$\left(a_{2}\right)$ the influence of intra-European and intra-continental trade is omitted;

$\left(a_{3}\right)$ the influence of competition between the European countries is omitted;

195 Frédéric Mauro, "Towards an Intercontinental Model: European Overseas Expansion between 1500 and 1800," The Economic History Review, sec. ser., No. 1(14), (1961), p. 2. 
$\left(a_{4}\right)$ continents are treated as entireties that purchase and sell products;

$\left(a_{5}\right)$ the intercontinental market is a buyer's market;

$\left(\mathrm{a}_{6}\right)$ all products have the same quality;

$\left(a_{7}\right)$ the technological level of the means of transport (ships) is constant.

The above overview of simplifying assumptions includes: quasi-idealizing assumptions $\left(\mathrm{a}_{1}, \mathrm{a}_{5}, \mathrm{a}_{6}\right)$, aggregating assumptions $\left(\mathrm{a}_{2}, \mathrm{a}_{3}, \mathrm{a}_{4}\right)$ and stabilizing assumptions $\left(\mathrm{a}_{7}\right)$.

Mauro distinguishes two continents located in the moderate zone: Europe and North America, and three continents located in the tropical zone: Africa, South America, and Asia. He studies the circulation of selected goods in the intercontinental trade. North America predominantly provided wool, cattle, wheat, and furs; Africa - workforce; South America produced tropical goods for the mass market; Asia - root vegetables and craft products; Europe specialized in production of industrial goods, means of transportation and possessed capital, knowledge and skills.

Based on the adopted assumptions, Mauro puts forward a thesis on the complementariness of production goods exchanged between continents. However, the presence of intercontinental competition undermined the complementariness. Mauro distinguishes four basic types of competition between:

- alternate products (e.g. between pastel dye and indigo dye);

- the same products originating from different zones in one climate zone;

- the same products originating from different climate zones;

- the same products originating from different zones with prices set at a level that makes it unprofitable to transport to other regions. ${ }^{196}$

The second thesis of the model states that intercontinental trade causes intercontinental division of labor and a system of domination that "is composed of dominating and dominated zones, which is reinforced by treaties, and which is directed by Europe, buying and selling at will. Any modification in the "Ed" zone leads to a change in the others, whereas the converse is not true." 197

Mauro emphasizes that the system of intercontinental dominance is hierarchical, i.e. all changes in Europe cause changes in South America, which lead to changes in Africa. To put it in another way: sugar buyers have dominated sugar producers who have made the slave traders dependent on him.

196 Mauro, “Towards an Intercontinental Model," p. 5.

197 Mauro, “Towards an Intercontinental Model," p. 7. 
A following of Mauro's statements, based on the basic idealizing assumptions, formulates a dependency demonstrating the development of a global import value:

$$
V=E+A+T+R+S
$$

Key: $V$ - global import value; $E$ - European import value; $A$ - African import value; $T$ - North American import value; $R$ - South American import value; $S$-Asian import value.

Afterwards, Mauro formulates a dependency allowing determining the global export value: ${ }^{198}$

$$
V=e+a+t+r+s
$$

Key: see above; small letters symbolize the export value of individual continents.

The determination of the global export and import values allows Mauro to determine the contribution of individual contents to the intercontinental exchange. ${ }^{199}$ The contribution is expressed with a ratio between global import (or export) value and import (or export) of individual continents:

$$
\frac{V}{E} \frac{V}{A} \frac{V}{T} \frac{V}{R} \frac{V}{S} \ldots
$$

Afterwards, Mauro determines the dependency of the size of profit in the intercontinental exchange:

$$
P=V-(A+R)
$$

Key: $P$ - value of profit; $V$ - value of sale; $A$ - capital necessary to rent the means of transport (ship); $R$ - cost of repair of the ship.

In the above formula, the level of profit predominantly depends on the costs of ship exploitation. As long as they are constant, the level of acquired profit remains unchanged.

In the second model Mauro reduces the assumption $\left(\mathrm{a}_{6}\right)$ stating that all goods have the same quality. ${ }^{200} \mathrm{He}$ distinguishes:

- high-quality products in the moderate continental zones;

- high-quality products in the tropical continental zones (including slaves);

198 Mauro, “Towards an Intercontinental Model,” p. 9.

199 Mauro, “Towards an Intercontinental Model," p. 10.

200 Mauro, “Towards an Intercontinental Model,” p. 8. 
- second-quality products;

- third-quality products.

The introduction of the quality of sold goods causes a modification in the statements of the first type - an intra-continental division of labor develops next to the intercontinental division of labor. For example, an economic sector producing third-quality goods develops in the Mediterranean Europe, continental Europe produced second-quality products, and Nordic Europe - first-quality goods. Corresponding transformations took place on the other continents; however, according to Mauro, their direction and range is less clear in comparison to Europe.

The socio-economic structure of separate continental zones, dependent on the quality of produced goods, modified the relations with other continents by increasing or decreasing the demand on specific types of goods.

Additionally, the above factor allows correcting the statements of the second type. It enables a deeper investigation of the structure of export and import of separate continents. Mauro conducts his study with reference to Europe. The trade exchange involving the European continent included export of goods of I and II quality and import of goods of I and II quality and silver from other regions of the world. Nonetheless, the differentiation of the quality of goods did not influence the level of gained profits.

In the third model, Mauro reinstates the assumption $\left(\mathrm{a}_{6}\right)$, but reduces the assumption $\left(\mathrm{a}_{7}\right)$ on the invariability of exploitation costs of the means of transport. The removal of this assumption allows discussing the process of acquiring profit in time: ${ }^{201}$

$$
P_{m-t 1}=V_{m}-\left(A_{t 1}+R_{t n}\right)
$$

Key: $P_{m-t 1}$ - profit acquired from the capital in the period from $t_{1}$ to $t_{n} ; V_{t n}$ - sale value in $t_{n} ; A_{t l}$ - capital required in $t_{1}$ to rent ships; $R_{t n}$ - cost of repair and exploitation of ships between $t_{1}$ and $t_{n}$.

Profit for the period $t_{n}-t_{1}$ increases annually, if the period of time $t_{n}-t_{\mathrm{n}}$ becomes shorter. According to Mauro, technological advancement reduces the period of time. The shift from wind-powered to steam-powered ships exerted the major impact. However, there were many previous technological inventions: the increase of profitability had been influenced by the introduction of a new type of ship - caravel, the discovery of new techniques of calculation of latitude and longitude, and the invention of a chronometer.

201 Mauro, "Towards an Intercontinental Model," pp. 14-15. 
The theory presented by Mauro has a star-like structure. On the force of the adopted assumptions $\left(a_{r}-a_{7}\right)$, he formulates statements concerning the structure of intercontinental exchange, contribution of individual continents to intercontinental trade and the conditions of acquiring profit. Subsequently, Mauro reduces the assumption $\left(\mathrm{a}_{6}\right)$ on the same quality of sold goods. It allows him to modify the statement on the structure of intercontinental exchange and further clarify the structure of exchange of the European continent. With reference to the third statement (on the level of profit), the reduction of the assumption is a degenerated concretization.

Finally, Mauro returns to his initial model and reduces the assumption $\left(\mathrm{a}_{7}\right)$ on the constant costs of exploitation of the means of transport. By including the factor of technical advancement that decreases the costs of exploitation, he can conceptualize the factors influencing the increase of profits. The structure of the theory can be demonstrated in the following way:

$$
M^{6} \leftarrow M^{7} \rightarrow M^{6}
$$

Key: $M^{\mathrm{i}}$ - model of the theory with an index indicating the number of simplifying assumptions; $\rightarrow$ - relation of concretization.

The absence of the procedure of approximation and empirical verification is a peculiarity of Mauro's theory. I would argue that it is a consequence of Mauro's goal approach to only introduce the problem:

The aim of this article was not to build up a model which could be concrete, dynamic and qualitative. That will be a long-term task, based on the combination of huge collections of statistics. Our aim has been more modest; to incite scientific research into undertaking this combination, by showing its interest. ${ }^{202}$

\subsection{A Recapitulation}

The above-presented examples demonstrate the fact that economic-historical theories are diversified. The theories have various structures: star-like or linear structure. Their authors implement a number of simplifying procedures: they introduce various assumptions: idealizing, quasi-idealizing, stabilizing, aggregating, etc. Economic historians employ various concretization strategies - some of them initially include the influence of many factors in the derivative models, others include only one factor and sometimes a concretization takes on the shape of territorial-chronological specification. In the cases under investigation, the statements formulated in the models have a qualitative character. The process

202 Mauro, “Towards an Intercontinental Model," p. 17. 
of operationalization of the idealizational statements is often a separate research undertaking.

The idealizational procedure is theoretically fruitful. However, its essential reconstruction does not constitute the predominant approach of the historical research. In my opinion, this is due to the fact that a number of metamethodological assumptions of the essential reconstruction of idealization are difficult to adopt in humanities. The assumptions conceptualized in ITS are unable to capture the specificity of the social sciences, especially history.

\section{The Limitations of the Method of Idealization}

A standard example of the scientific conduct in ITS is a set of procedures adopted in the natural sciences and particularly in physics. Furthermore, there is a silent agreement that the domineering type of causality in the natural sciences is the regular causality. ${ }^{203}$ For this reason, by knowing the most essential determinant of a given phenomenon we can predict its future states, with a satisfying approximation, among other things. The influence of incidental factors causes disturbances in the regular behavior of a phenomenon gradually or has predictable consequences. ${ }^{204}$ This method of comprehension of causality in the natural sciences in the essential reconstruction of idealization is mechanically transferred onto the area of the social sciences.

However, the most recent accomplishments of the chaos theory demonstrate that this image of the natural sciences calls for a substantial correction. Even the simple phenomena, i.e. a simultaneous collision of three billiard balls, behave in an unexpected way. ${ }^{205} \mathrm{~A}$ characteristic feature of the phenomena subjected to chaotic causality is their:

203 For an attempt of conceptualization of regular and chaotic causality in the terms of categorical ontology, see: Leszek Nowak, "O zagadnieniu tak zwanej transformacji ustrojowej," in: Społeczna transformacja w refleksji humanistycznej, ed. Krystyna Zamiara (Poznań: Wyd. UAM, 1994), pp. 122-123.

204 C.f. Andrzej Fuliński, “O chaosie i przypadku. A także o determinizmie, redukcjonizmie i innych grzechach fizyków czyli o zmianach w obrazie świata widzianych okiem jednego z nich," Znak, No. 5 (1979), pp. 31-50; Michał Tempczyk, “Chaos a harmonia świata," Znak, No. 5 (1993), pp. 50-56.

205 Cf.: Fuliński, “O chaosie i przypadku," p. 38; John C. Polkinghorne, "Prawa przyrody i prawa fizyki," Znak, No. 5 (1993), p. 62; Ian Stewart, Does God Play Dice? The New Mathematics of Chaos (Malden/Oxford: Wiley-Blackwell, 2002), pp. 18-37. 
uttermost instability - extremely high sensitivity to any, even tiny disturbances. The future becomes unpredictable when even a tiny change (disturbance) of movement at any time can cause future changes of any size. [...] In other words, a small cause can lead to enormous consequences. ${ }^{206}$

The intuitions of the chaos theory are even more frequently applied in the historical sciences where the principal factors exert a significantly weaker impact and where, in consequence, a historian approaches the problem of abstracting from seemingly "inessential" secondary circumstances with great caution. Michael Shermer pondered on the issue of implementation of basic intuitions of the chaos theory to the area of historical research and developed a so-called chaotic model of historical sequences. ${ }^{207}$ According to the model, a historical process is a resultant of not only necessity and order but also contingency and chaos. Shermer perceives a contingent event as "a conjuncture of events occurring without perceptible design" 208 and necessities as "constraining circumstances compelling a certain course of action." ${ }^{209}$ Every historical sequence begins with bifurcation a focal point where a number of necessities is balanced with other necessities, whereas factors behave unpredictably and are subject to chaotic regularities. However, in the course of historical evolution, a number of necessities become dominant. The influence of a trigger of change (trigger effect) may determine which one of the factors will become dominant. Under normal circumstances the trigger effect is inessential, but it brings about substantial consequences and leads to a shift in direction of a historical evolution. The sooner a trigger of change appears in a historical sequence, the greater the influence it exerts. The later it appears, the smaller the influence. Shermer argues that the transitions

206 Fuliński, “O chaosie i przypadku,” p. 37.

207 Michael Shermer, "Exorcising Laplace’s Demon: Chaos and Anti-chaos, History and Metahistory," History and Theory, Vol. 34, No. 1 (1995), pp. 59-83. See also a discussion on the question of employment of the theory of chaos in history in History and Theory, especially the following articles: Donald N. McCloskey, "History, Differential Equations, and the Problem of Narration," History and Theory, Vol. 30, No. 1 (1991), pp. 21-36, George Reisch, "Chaos, History and Narrative," History and Theory, Vol. 30(1) (1991), pp. 1-20, George Reisch, "Scientism without Tears: A Reply to Roth and Ryckman," History and Theory, Vol. 34(1) (1995), pp. 45-57. Paul A. Roth and Thomas S. Ryckman, "Chaos, Clio and Scientific Illusions of Understanding," History and Theory, Vol. 34(1) (1995), pp. 30-40.

208 Shermer, “Exorcising Laplace's Demon," p. 70.

209 Shermer, "Exorcising Laplace's Demon," p. 70. 
from chaos to order are gradual and common, while the shifts in the opposite direction, i.e. from an organized state to a chaotic state, are sudden and rare.

However, Shermer's proposals are imprecise and have aroused serious doubts. First, he fails to provide a detailed description of the state of bifurcation in which a number of necessities is balanced with other necessities. Consequently, the purpose of the trigger of change is unclear. Is it supposed to introduce transitions from the domain of order and necessity to the domain of contingency and chaos - "trigger of change is any stimulus that causes a shift from the dominance of necessity and order to the dominance of contingency and chaos"210 or is its sole purport to decide which of the balanced necessities win in the state of bifurcation - "trigger of change will be most effective when well-established necessities have been challenged by others so that a contingency may push the sequence in one direction or the other"? ${ }^{211}$ For one thing is shift between the types of regularity (regular to chaotic) that a given phenomenon is subject to, and another is a shift from one necessity to another within a given type of regularity (regular or chaotic). I aim to avoid the above-described ambiguities by suggesting an explication the following chapter of this book of intuitions of the coexistence of regularities and contingencies in history, as formulated in a conceptual apparatus of the idealizational theory of science.

The principal theses of the chaos theory confirm the intuitions shared by many historians that history has been unpredictable. ${ }^{212}$ Furthermore, practicing historians and historical methodologists devoted to professional pondering on history both express a conviction that the comprehension of laws operating in the social world from the viewpoint of natural science is insufficient to historical cognition:

Our modern-day view of the past is fatally burdened with determinism: [...] The problems of historical alternatives and different development of events to the one that actually happened have been entirely excluded from the area of the scientific historical research and an attempt was made to knock them down to the level of "journalism." In consequence, the historical sciences were result substantially impoverished. They turned into an area of research of small and large historical facts, and insignificant and significant developmental processes usually forced into the framework of an adopted

210 Shermer, "Exorcising Laplace's Demon," p. 72.

211 Shermer, "Exorcising Laplace's Demon," pp. 72-73.

212 For a discussion on the application of the theory of chaos to the development of historical narrative and the structure of explanation, see: Topolski, Jak się pisze i rozumie historię, pp. 251-267. 
in advance convention of the "regularity" of a particular development of facts and processes that are attempted to be stigmatized with a stamp of total inevitability. ${ }^{213}$ This perception (of the fatalistic influence of the social sciences) transfers the relations relevant to the reality of the natural sciences onto the social reality. This situation applies to the entire problem of determinism that shifted during the era of Positivism from the natural sciences onto the social reflection. Let us add that the theory of historical materialism has also been subjected to a naturalistic deformation and that it still ineffectively struggles to absolve itself from it. The simple explanation is that a positivist viewpoint is more approachable and usually more compatible with a common reflection slanted toward solutions from the category of simple relations, than the standpoints offering a deeper comprehension of the cognitive process. ${ }^{214}$

I find it noteworthy to investigate the intuitions expressed by historians. ${ }^{215}$ Hence, I will discuss the viewpoints of four authors who put forward opinions on alternatives in the historical evolution: Jerzy Łojek, Jerzy Topolski, Jan Pomorski and Marceli Handelsman.

Alternative developmental lines are not unique in the historical process. As argued by Łojek, they are present in almost all landmark moments in history:

All historical processes, without exception, from the largest socio-economic transformations to the political accidents shaping the face of individual countries or of a part of the world had during their onset and development substantial alternatives lasting a lifetime of one or more generations. It is clearly visible in the history of great political and military conflicts that the beginning of every historical process resembles crossroads with roads initially close to each other, and later divided by a growing space. Sometimes the moment of entering the crossroads of history was very brief, sometimes it has not even

213 Jerzy Łojek, Wokót sporów i polemik (Lublin: Wydawnictwo Lubelskie, 1991), p. 6.

214 Jerzy Topolski, Wolność i przymus w tworzeniu historii (Warszawa: PWN, 1990), p. 21.

215 The problematics of the "counter-factual history" in New Economic History is certainly close to the method of idealization in the historical sciences and the issue of developmental alternatives in history. In Pomorski's interpretation, counter-factual models always adopt a more general view of the socio-economic development that allows for an analysis of realistic and alternative developments. Additionally, counter-factual models have to be historically realistic. This means that the factor substituting for the action of a given variable in the counter-factual model should exist in the historical reality. All variables of the model should also be operationalized and we should remember about the rule of representativeness of statistic data during their quantification, see: Pomorski, Paradygmat "New Economic History," pp. 129-132. I will not be getting deeper into the issue because the counter-factual models developed under the New Economic History do not consider the historical alternatives inherent in the historical process understood as a whole, but only in a given, specific field of economic history. 
been noticed by the historiography. Sometimes, the direction of history was determined by a mere coincidence and more often by a decision of a person aware of the purposes but oblivious of the consequences... And sometimes there were other possibilities. Our knowledge is being substantially impoverished by the persistence to research only the selected line of development. ${ }^{216}$

According to Łojek, the direction of human behavior and actions determines the selection of a developmental possibility. In turn, human actions are conditioned by the state of social consciousness. And the shape of social consciousness deciding on the direction of the evolution of human history, currently perceived as inevitable and necessary, is a result of a conjunction of various, sometimes entirely coincidental events and circumstances. A developmental alternative is frequently selected by chance. Human history, as Łojek concludes his study, could have easily unfold into a different direction in the landmark moments.

Topolski describes the nature of the historical process correspondingly. $\mathrm{He}$ purports to explain the phenomenon of alternatives intrinsic to a historical process with an analogy between biological development and social development:

Here, the situation is similar to the situation of a gene pool that in the course of evolution became greatly polymorphic, that is, greatly [...] diversified with reference to individual populations. This gene pool created opportunities for a relatively fast adaptation to the new conditions. ${ }^{217}$

Whereas in the course of social evolution, the place of the gene pool is taken by human knowledge collected over time (Topolski terms it an information pool). This knowledge indicates the possibilities to take alternative actions. According to Topolski, history is always a pool of alternatives. Which one of these alternatives is selected for implementation depends on a conscious human choice or on a coincidence that points the historical process into a particular direction. The pool of possibilities intrinsic to the historical process is determined by factors external to human will. The execution of a selected developmental alternative may be a resultant of a conscious human choice. The more adequate the knowledge of social conditions possessed by the people in the moment of action, the less significant the function of coincidence in history.

According to Pomorski, the historical process is a hierarchy of social practices. ${ }^{218} \mathrm{He}$ distinguishes three basic types of practice: socio-material

216 Łojek, Wokół sporów, p. 8.

217 Topolski, Wolność i przymus, p. 22.

218 Jan Pomorski, W poszukiwaniu modelu historii teoretycznej (Lublin: Wyd. UMCS, 1984), pp. 115-136. For an alternative prioritization of social practices, see: Andrzej Klawiter, "Teoria formacji społecznej w materializmie historycznym," in: Założenia 
practice, legal-political practice and cultural practice. Socio-material practice is the paramount practice. It consists in merely reproducing people and ensuring the means enabling their existence. Legal-political practice sanctions the social relations existing in a given society and constituting material social practice. In terms of functionality, legal-political practice is subordinated to production practice. Following from this, a given legal-political practice becomes widespread from a determined pool of legal-political practices is the one that guarantees the achievement of the highest production level in a given society. Socio-cultural practice constitutes another type of practices. In terms of functionality, it is subordinated to socio-material practice and legal-political practice. Its purpose is to provide motivation to undertake social action within the two above-mentioned practices and to formulate rules and regulations for an effective action. According to Pomorski, alternatives in historical development appear at the interface of the two types of practice: production practice and legal-political practice. In terms of functionality, legal-political practice is subordinated to production practice. However, legal-political practice counterinfluences production practice. A given state of social legal-political practice allows for a pool of methods to produce goods of a particular level of effectiveness. The levels of effectiveness of production methods can be ordered from the least effective to the most effective. The selection of a particular legal-political practice counter-influences the production level. Pomorski terms the relation a stimulation of manufacturing practice by a legal-political practice. As a result of the stimulation (of the counter-influence of the political practice), the production practice adopts a less or more effective variant, respectively. He claims that this is the source of a historically documented phenomenon of deepening economic differences between countries that "set about" from the same level (not a long time ago) and, subsequently, found themselves in different socio-economic formations. This state of affairs was influenced by the choice of a variant of a social legal-political practice that stimulated the production practice. Pomorski concludes his investigation with the following words:

[A historical process is] a shift from the historically probable to the historically necessary, in the course of the increasing objective effect of a series of human actions. Therefore, for every historical moment there are alternative lines of future development available in a given moment; some of them are being gradually blocked in the course

materializmu historycznego, ed. Leszek Nowak (Warszawa-Poznań: PWN, 1978), pp. 233-258. 
of a series of human actions reducing the possibilities, narrowing down the range of opportunities until - finally - there is only one left, historically necessary at the time. ${ }^{219}$

Marceli Handelsman expressed a slightly different viewpoint on the possibilities of alternative historical development. ${ }^{220}$ The historian developed his ideas into a more systematic way and created a theory of possibilism. Handelsman put forward an observation that a historical process has a triple nature. It comprises of three types of factors: intentionally caused by humans, selected by an individual from many available options, and enforced and indelible. Our approach to history depends on our choice which of the three distinguished factors is given primacy. Depending on the chosen hierarchy, history is a result of rational and intentional human decisions, a result of a series of coincidences or an area of operation of blind forces of nature. Hence, the triple nature of the historical process will always provoke questions concerning the limits of human freedom and the role of necessity in history.

Handelsman argues that an individual human being, mentally and physically unique constitutes the subject of history. However, a human endowed with a unique personality undertakes actions that have consequences and implications of a proper and necessary character - a change of the social environment. Hence, a unique and exceptional human consciously committing to an action, simultaneously becomes a source of determinisms for the social world. Following from this, the undertakings of an individual human being are most definitely not free, as he/she is subject to a number of external conditions. According to Handelsman, the most constant ones include geographical environment, as climate, the properties of soil, etc. impose on humans the methods of solving social problems - food production, way of dressing, etc. A social structure external to the autonomous subject constitutes another factor shaping human behavior. A particular system of cooperation and social interaction, production methods, ways of satisfying needs are the factors most determining for human behavior.

However, the above-defined social and geographical determinism do not determine the entire history of human kind, because contradictory tendencies and factors may counterbalance and intersect with each other. Only then, when the opposing tendencies are mutually counterbalanced, appear the hiatuses, as

219 Pomorski, W poszukiwaniu modelu, p. 86.

220 Marceli Handelsman, "Possibilities and Necessities of the Historical Process," in: Idealization XIII: Modeling in History, ed. Krzysztof Brzechczyn (Amsterdam/ New York: Rodopi, 2009 [1931]), pp. 33-42. 
Handelsman terms them, or situations when factors that used to determine history, balance each other and it appears as if history has paused.

In this sequence of factors, the conscious, purposeful will of humans is sometimes an insignificant factor. Sometimes, when a pause is longer and level of mutual counterbalance of different tendencies is greater conscious and purposeful will of humans becomes a principal factor. When human will once enters the chain of forces, despite its most par excellence individualistic origins, it influences further progress of events in a way that could be described as deterministic; on an equal footing with other non-human forces. ${ }^{221}$

Between the two radical interpretations of history - fatalism that eliminates human will from history and voluntarism that credits human activity with the role of the only history-shaping factor, Handelsman situates the concept of possibilism defined in the following way:

In this formula, the foreground is obviously occupied to a large extent by non-human factors, under which I also subsume the nature of human psyche itself and the nature of human activity. The domain of non-human phenomena is thoroughly and exclusively mental and is always permeated by mentalism. [...] Thus, the domain of non-human phenomena is a sphere of interrelations that are connected logically by the consequences of causes and effects. It is a sphere of phenomena that developed deterministically. The world of the deterministically defined phenomena permeated by mentalism is connected with the world of randomness, the world of human individuality. Through the entanglement of influences, surrendering to instantaneous suspension of the necessities that govern it, the world opens up the possibilities of the operation for individualities, with which it is at any rate strongly united. ${ }^{222}$

In Handelsman's view, the above vision of a historical process imposes on the theoreticians and researchers of the past, the obligation to identify and recognize the scope of human freedom in history and the range of determination.

I would like to supplement the above-presented ideas of the prominent historians with the opinions of philosophers pondering on the nature of history. For example, Hans-Georg Gadamer puts forward an observation that history has always included a paradox of "small causes and huge effects:"

If it is an old fundamental principle of the knowledge of nature that the cause must be equal the effect, the opposite is true when it comes to the experience of history: small

221 Handelsman, "Possibilities and Necessities," p. 40.

222 Handelsman, "Possibilities and Necessities," pp. 40-41. 
causes have huge consequences. It obviously belongs to the experience of those who stand within history that it surprised them..$^{223}$

General history is supposed to be an area where human freedom is manifested in the most outstanding way:

This formulation makes history appear as a staged drama, In it, there are scenes, which initiate the affected spectators into a new direction taken by the course of things. It may be that the course of things is determined in general by the given circumstances in such a way that many possibilities are foreclosed and only a few open. Yet, the complex in which world history fits is anything but knowable or even foreseeable in its necessity. The complex does not have the character of the connection between cause an effect in the way it underlies our knowledge and calculation of the course of nature. ${ }^{24}$

Gadamer solves the paradox of small causes and huge effects on a metaphysical plane. He argues that in the human history causes act in a teleological way. Therefore, the historical processes:

seems as if, like the process of production, they a guided by pre-existing purpose, striving toward pre-determined form, for example, the form of the developed living organism. All this seems as if what already exists sets itself into motion toward its ultimate form. This material, which we prefer to call matter, appears to generate out of itself the process of becoming and change. ${ }^{225}$

A discussion of the paradox of small causes and huge effects can be conducted on the metaphysical plane, but it is equally worth considering if the paradox could be solved by smaller means, without engaging in inevitably controversial, lifelong disputes of metaphysicians. The paradox of small causes and great effects can be also discussed on the methodological plane. In the further part of this chapter, I will characterize Gadamer's paradox of small causes and huge effects in the terms of idealizational theory of science, however, it is equally possible to explain this paradox using the languages of other methodological concepts.

The problem of alternatives in the historical development has been addressed on the plane of categorical ontology in the problematic of categorical differentiation; however, no methodological consequences have been drawn. ${ }^{226}$ In its

223 Hans-George Gadamer, Is There a Causality in History, in: Hermeneutics between History and Philosophy: Selected Writings, Vol. 1 (London: Bloomsbury Academic, 2016), p. 4.

224 Gadamer, "Is There a Causality," p. 4.

225 Gadamer, "Is There a Causality," pp. 8-9, see also p. 12.

226 Leszek Nowak, Wykłady z filozofii marksistowskiej, Vol. 2: Ontologia i epistemologia (Poznań: Wyd. UAM, 1978), pp. 34-44. 
current shape, ITS does not include the methodological peculiarities of built and structure of the idealizational theories of science capable of taking up the question of developmental alternatives in history. One of these issues is the above-mentioned paradox of small causes and great effects. To explain this paradox, I shall extend the conceptual apparatus of ITS by an effect, termed by me a cascade effect, and will follow with a determination of changes brought by this effect, among others, into the structure of a scientific theory and the construction of a historical narrative. 



\section{The Methodological Characterization of the Cascade Effect}

\section{Two Types of Essential Structures}

In their research practice, scientists come across two types of essential structures of phenomena under investigation. In the case of the first type, it is enough to examine the influence of the principal factor, to approximately define the influence of secondary factors and, on the basis of an approximated idealizational law, to formulate a prognosis that will satisfactorily define a behavior of the phenomenon under study. In the case of the second type, ascertaining of the influence of the principal factor proves to be insufficient to formulate the prognosis with the requested degree of accuracy. In this case, it is necessary to implement an almost complete concretization of the idealizational law. Subsequently, after the reception of sufficiently precise theorem, the influence of the remaining but less important, secondary factors is approximated. It is only then - after the procedures of concretization and approximation of the idealizational law are implemented - that a prognosis can be formulated that will define the behavior of a phenomenon under investigation to a sufficient degree in a given time and in a given domain of science. ${ }^{227}$

In their discussion of the problem, Katarzyna Paprzycka and Marcin Paprzycki use the example of a tossed coin. Knowledge of two most main important

227 See: Katarzyna Paprzycka and Marcin Paprzycki, "Accuracy, Essentiality and Idealization," in: Idealization III. Approximation and Truth, eds. Jerzy Brzeziński and Leszek Nowak (Amsterdam - Atlanta, GA: Rodopi, 1992), pp. 255-265. The authors ponder on the problem of why it is enough to recreate the influence of the principal factor to satisfactorily explain and predict the conduct of a particular phenomenon, while each subsequent concretization enhances the accuracy of the initial idealizational law. In other cases, to be able to explain the conduct of a given phenomen it is necessary to introduce almost all factors into the models of a given theory. According to the authors, this paradox is caused by the issue of separating the exclusion ranges of factors, which influence a given magnitude $F$. If the exclusion ranges of individual factors are separate, then each subsequent concretization enhances the accuracy of the idealizational law. However, if the exclusion ranges of individual factors intersect or overlap, then the subsequent concretizations do not enhance the accuracy of the idealizational law. In such case, it is necessary to include the influence of "almost all" factors. 
factors: the weight of the coin and the distance of the fall prove to be of little use in finding the side on which the coin will fall. Therefore, in order to formulate a precise prognosis, one should consider the influence of the remaining factors: the force of the toss, the rate of rotation around the axis, the shape, etc.

In the face of the phenomena of various types of essential structures, a researcher implements different strategies of construction of idealizational theories of science. In the first case, a scientist, after determining the influence of the principal factor, implements a procedure of approximation of the influence of the remaining factors and arrives at a satisfactory explanation of a phenomenon under investigation. In the second case, by contrast, a researcher, after formulating the idealizational law, has to implement an almost full concretization. Only then he/she can approximate the influence of the secondary factors and come forward with satisfactory explanation of a phenomenon under study.

On the basis of the above distinction, it is possible to identify two types of an essential structures: an essential structure dominated by the principal factor and an essential structure dominated by a class of secondary factors. In an essential structure dominated by the principal factor, the power of influence that it exerts is greater than the sum of the power of influence of secondary factors. On the contrary, in an essential structure dominated by secondary factors, their total influence is greater than the influence exerted by the principal factor, although the power of influence of the latter is, by definition of an essential structure, greater than the power of influence of each secondary factor taken separately. The two types of essential structures in question can be graphically demonstrated in the following way:
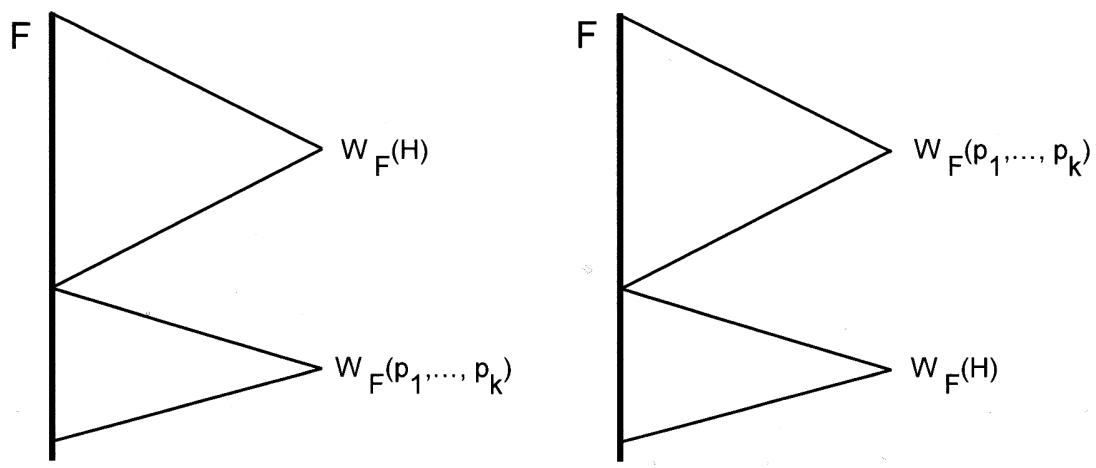

Fig. 4: Two types of essential structures. Explanations: left: an essential structure dominated by a principal factor; right: an essential structure dominated by secondary factors. 
The above distinction allows explaining the differences between the two types of phenomena. The approximation of the idealizational law is sufficient to explain phenomena of an essential structure dominated by the principal factor. In such a structure, the advantage of the principal factor over the secondary ones is so significant, that it is sufficient to determine the influence of the principal determinant for a given phenomenon. However, in the face of phenomena of the essential structure dominated by the class of secondary factors, an almost full concretization of the idealizational law should be used, combined with the approximation of the concretized theorem. Since in that type of structure the power of influence of the principal factor is smaller than the power sum of influences of a class of secondary factors, ascertaining the influence of the principal determinant by itself is insufficient to explain the phenomenon under study. As a result, one has to implement a number of concretizations of the preliminary idealizational law.

The first type of essential structures - dominated by principal factor - seems characteristic of the phenomena occurring in the natural world. On the contrary, the second type of essential structures - dominated by a class of secondary factors - is characteristic of the phenomena occurring in the social world. The differences between phenomena belonging to the natural and social worlds are one of the sources of the methodological peculiarity of the humanities.

The evidence of the above-discussed issue can be found e.g. in the historians' research practice. In the historical sciences, it is unusual to explain any phenomenon by revoking to the influence of only one factor. As a rule, explications provided by historians are multi-factorial. For example, in his consideration of the reasons for the development of Protestantism in 16th-century Poland, Henryk Samsonowicz states "there have been many factors for such a rapid growth of Reformation." 228 Samsonowicz lists two groups of factors. The first group includes factors that discouraged to Catholicism, and the second group includes those that encouraged converting to Protestantism. The first group includes social disapproval of the Catholic Church that ensued from treating this institution as an ideological embodiment of the existing social order. On that account, burghers were reluctant toward the Church because the Catholic type of piety impeded running their businesses. The peasantry had also expressed disapproval of the Church, since they had to pay the tithes. Moreover, the nobility and a part of the magnates were reluctant toward this institution because they

228 Henryk Samsonowicz, Historia Polski do 1795 (Warszawa: Wydawnictwo Szkolne i Pedagogiczne, 1985), p. 159. 
envied its economic wealth. In addition, it was depravity among the clergy, such as the dissipation and lack of moral fiber, that brought disrepute onto this social group. Another factor that undermined the authority of the Church was poor intellectual standards of the majority of the clergy. Insufficient knowledge, i.e. poor familiarity with the Bible on the part of the Catholic priests, was becoming even more significant in the 16th century, after the Gutenberg's invention, when the book was becoming a mass product and the level of general education of the society was increasing.

Nonetheless, Samsonowicz lists many features of Protestantism that affected its attractiveness for the social elites of the 16th-century Poland. According to him, most importantly, the religion provided weapons for the battle against the political and economic privileges of the clergy. Moreover, Reformation itself constituted an expression of the development of national consciousness, as it broke with the Catholic medieval cosmopolitism and substituted it with national churches. In the domain of language, Latin was replaced with Polish language. Additionally, the nobility found the democratic system of the Calvinist communes more suitable in the battle for strengthening of the nobles' democracy, than the catholic centralism. Finally, Protestantism was intellectually more attractive than Catholicism, since it emphasized the importance of individual development and encouraged individual contemplation of the truths of faith, through regular studies of the Bible.

The example presented above proves that the multi-factorial interpretation is a natural kind of explanation used in history. The above-quoted historian does not limit his illustration to one reason which, from his perspectives, was responsible for the dissemination of Protestantism. Instead, he gives at least eight separate factors, which contributed to the development of Reformation in the 16th-century Poland.

\section{On Small Causes and Huge Effects}

Yet another effect may occur in the essential structures dominated by the class of secondary factors. Frequently, some phenomena that were subject to some factors that exert the main influence on them in a given period of time are influenced by new, different secondary circumstances. Initially, the influence of the coexisting accidental factors modifies merely the basic regularities; however, afterwards, it introduces essential disturbances into them, and finally balances the impact of the factor principal for the phenomenon under study. In the final stadium, the accumulation of these accidental factors that occur together may become so great that it surpasses the influence of the regularity that the phenomenon under investigation was subject 
to so far. We could say that the impact of the principal factor is overbalanced by, figuratively speaking, "a cascade" of secondary factors which together exert a greater influence on the analyzed phenomenon than does the principal factor.

The simple cascade effect consists in introducing subsequent secondary factors. An essential structure dominated by the principal factor in the initial stage transforms, under the influence of gradual occurrence of new secondary factors, into an essential structure dominated by secondary factors. An inverted cascade effect is the disappearance of the influence of some secondary factors that brings the domination of the principal factor back again. Thus, in the simple cascade effect an essential structure of the first type becomes gradually transformed into an essential structure of the second type in which the common power of influence of the secondary factors is greater than the power of the influence of the principal factor.

This can be illustrated in the following way:
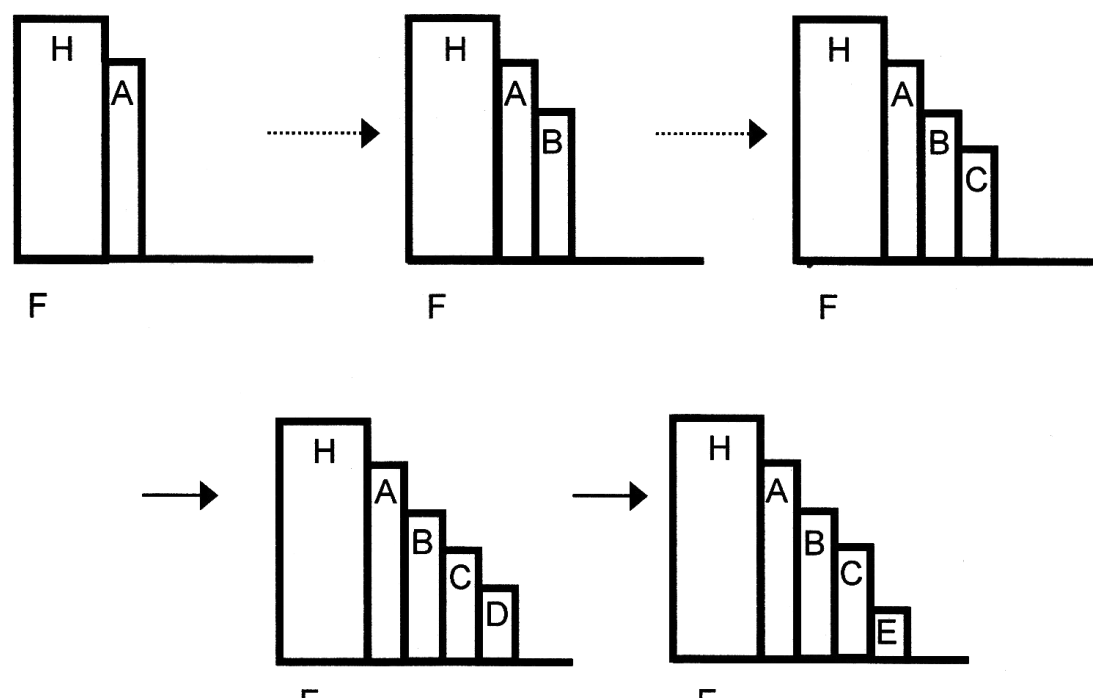

$\mathrm{F}$

$\mathrm{F}$

Fig. 5: A cascade process. Explanations: if factors $A, B, C$ appear in the essential structure of the magnitude $F$, then $W_{F}(H)>W_{F}(A, B, C)$; if there appears factor $D$, then $W_{F}(H)$ $=W_{F}(A, B, C, D)$; and the factor $E$ appears, then $W_{F}(H)<W_{F}(A, B, C, D, E)$; if factor $D$ disappears from the essential structure of the magnitude $F$, then $W_{F}(H)>$ $W_{F}(A, B, C, E)$.; a solid line arrow stands for transformation of the essential structure of the phenomena under investigation from a structure dominated by the principal factor to a structure dominated by secondary factors or the reverse; a dotted-line arrow designates transformation within an essential structure dominated by the principal factor. 
The above illustration presents the magnitude $F$ under investigation and a number of factors influencing the studied phenomenon in a various ways. These factors include the factor $H$, which is the principal factor, as it exerts influence in the entire period of time under consideration and as its power of influence is the largest. The next factor, factor $A$, exerts secondary influence, however, also in the entire period of time under consideration. The further factors, $B$ and $C$, appear later and exert relatively smaller influence on the phenomenon under investigation. Nonetheless, they initiate the cascade process, in which the role of the influence of the principal factor changes in the structure of influence. Although the power of influence of this factor is still the greatest, its dominance over the remaining factors belonging to essential structure, gradually diminishes with the occurrence of the new secondary factors, i.e. the number of elements of the set $\left(W_{F}(H)-\left(W_{F}(A, B, C \ldots)\right)\right.$ decreases. In turn, the appearance of the factor $D$ "almost balances" the power of influence of the principal factor with the sum of power of influences of secondary factors. When the next factor $E$ occurs the secondary factors gain dominance in the essential structure. Then, also the sum of power of influences of the secondary factors $A, B, C, D$ and $E$ becomes greater than the power of influence of the principal factor. A cascade lasts as long as the secondary factors are able of maintaining dominance in the essential structure. The disappearance of the influence of any of the factors in a cascade brings back the domination of the principal factor. In the figure above, the factor ending the dominance of secondary factors is the factor $D$ that does not occur in time $t^{3}$ and brings back the dominance of the principal factor. In a limit case, the same magnitude can be the factor that both closes a cascade by initiating the dominance of secondary factors in the essential structure, and ends the dominance of these factors.

I find it noteworthy to compare the above-explained cascade model with Michael Shermer's model of historical sequences presented in the previous chapter.

(1) The above-presented conception can determine with great accuracy the nature of a focus point, or a state in which the power of influence of the principal factor,, on the one hand, and the joint powers of influence of a cascade of secondary factors, on the other, remain in a mutual balance. This state occurs when the domain of exclusions of values of the magnitude $F$ with respect to the principal factor $H$ is equal to the domain of exclusions of values of the magnitude $F$ with respect to secondary factors $A, B, C, D$, which can be put in symbols, as $W_{F}(H)=W_{F}(A, B, C, D)$. Then, whether the 
principal factor or a cascade of secondary factors gains dominance in an essential structure of a given phenomenon depends on the occurrence or lack of occurrence of a factor that closes the process of a growing cascade.

(2) In a model of a cascade processes, the factor $E$ plays the function of a "trigger of change," however, the consequences of its actions, in contrast to Shermer's model, do not "depend" on the moment of its occurrence in a cascade process, but on whether the balance of influences between the principal factor and the secondary factors is reached or not.

(3) On its own, the factor $E$ is unable to balance the influence of the principal factor $H$. When a process of a cascade increase is advanced enough it merely leads to turning the scale of influences in favor of the secondary factors. To put it in Shermer's words, a factor which closes a cascade cannot cause "a shift from the dominance of necessity and order to the dominance of contingency and chaos," but can, in a determined state of bifurcation, decide which of the necessities remaining in balance (the principal factor or a cascade of secondary factors) will dominate in an essential structure of the phenomenon under investigation.

(4) As opposed to Shermer's model, a cascade process is reversible. The disappearance of the factor $E$, or of any other factor of a similar power of influence, brings back the domination of the principal factor.

(5) In contrast to Shermer's model, the transformations within an essential structure - a shift from the state of dominance of the principal factor to that of dominance of a cascade of secondary factors, and an inverse shift from the state of dominance of the secondary factors to that of the principal factor - have a gradual nature; the probability of their occurrence is the same.

(6) As opposed to Shermer's model, the cascade effect cannot occur anywhere and always. It does not occur anywhere, because it can occur only in a certain type of essential structures that are dominated by a class of secondary factors. Nor does it always occur, for it occurs only when a process of cascade increase is sufficiently advanced, namely, when the influence of gradually accumulated secondary factors balances the influence of the principal factor. Only then the occurrence of a "small cause" can bring about "great effects" a dominance of a cascade of secondary factors in an essential structure of a phenomenon under investigation.

The cascade effect may also interpret the paradox of "small causes and huge effects" observed by Gadamer in history. The appearance of the factor $E$ is the "small cause" that initiates "great effect" - a modification in the dependencies that 
the phenomenon under investigations has been subject to so far. Since then, a phenomenon is affected by the influence of cascade factors that exert primary influence over it and the influence of the principal factor merely modifies this primary influence. However, the paradox of "small causes and huge effects" does not occur anywhere and always. It does not occur anywhere, because it can come to existence only in a particular type of an essential structure, namely, such that is dominated by a class of secondary factors. Nor does it always occur, for it appears only when a process of accumulation of the cascade is sufficiently advanced, hence, when the powers of influence of the gradually accumulating secondary factors balances the impact of the principal factor. Only then, the appearance of a "small cause" initiates "huge effects" - the dominance of the cascade of secondary factors in the essential structure of the phenomenon under investigation.

The cascade effect allows us to explicate one of the variants of the concept of a "turning point" present in historical works. Such moments in history occur when the influences of two historical tendencies are counterbalanced. In light of the cascade effect, it is the influence of the principal factor that is counterbalanced by the impact of the secondary factors. Then, the appearance or absence of the factor closing the process of accumulation of the cascade decides if the principal factor or a cascade of secondary factors will gain dominance in the essential structure of a given phenomenon. In the further part of the present book, I will examine what does the above-explicated cascade effect introduce to the structure of a scientific theory and a historical narrative, and I will present the ongoing discussion on the methodological foundation of the nomothetic and idiographic approaches to history.

\section{The Interaction of Factors in the Cascade}

A cascade of factors may be of differing structures. The factors occurring in it may separately influence the magnitude under study, or they may interact with each other. At this point, it is time to implement the definition of an interaction of variables (factors, according to the adopted terminology) offered by Ackoff. According to him, "two variables interact, if the effect which one has on the dependent phenomena depends on the value of the other." 229

In terms of ITS, the interaction between two factors $A$ and $B$ belonging to the essential structure of the phenomenon $F$ occurs, when the joint influence of

229 Russell L. Ackoff with the collaboration of Shiv K. Gupta and J. Sayer Minas, Scientific Methods: Optimizing Applied Research Decision (New York and London: John Wiley \& Sons, Inc., 1962), p. 317. 
these factors exerted on $F$ depends on the values that each of these factors adopt separately. ${ }^{230}$

Any two secondary factors $A$ and $B$ influence $F$ in isolation, if the joint area of influence of $A$ and $B$ on $F$ is equal to the sum influences of each factor considered separately. ${ }^{231}$

$$
W_{F}(A B)=W_{F}(A) \cup W_{F}(B)
$$

Whereas if the factors $A$ and $B$ enter into interaction, their joint area of influence on $F$ is not equal to the sum of areas of influence exerted by each factor separately on $F$.

$$
W_{F}(A B) \neq W_{F}(A) \cup W_{F}(B)
$$

Let us now consider the possible types of interaction with the example of two factors, $A$ and $B$. In order to do that, we will order the set of cases of the factor $A$ with respect to the power of influence - from minimal to maximal - exerted on them on the magnitude $F$ under study. In the set of cases of the factor $A$, one can distinguish cases with minimal influence on $F$. One can also distinguish a class of cases of the factor $A$ where the influence exerted on $F$ is maximal. Finally, it is possible to distinguish cases with the power of influence smaller than maximal and yet larger than minimal.

The weakening interaction between $A$ and $B$ in respect to $F$ occurs when the factor $A$, under the influence of $B$, adopts a value at which the power of influence exerted by $A$ on $F$ is decreasing. By contrast, the strengthening interaction between $A$ and $B$ occurs when $A$, under the influence of $B$, assumes a value at which the influence of $A$ on $F$ is increased.

Thus, in the interaction, the impact of $A$ on $B$ (or vice versa) indirectly ascertains the influence $A$ (or $B$, respectively) exerts on $F$. Depending on the type of interaction, the influence of $A$ on $F$ may decrease or increase.

The weakening interaction between $A$ and $B$ in respect of $F$ occurs when the joint area of influence of the factors $A$ and $B$ on $F$ is smaller than the sum of influence of the factors $A$ and $B$ exerted separately on $F$.

$$
W_{F}(A B)<W_{F}(A) \cup W_{F}(B)
$$

230 Jerzy Brzeziński, Struktura procesu badawczego w naukach behawioralnych (Warszawa - Poznań: PWN, 1976), p. 18.

231 Leszek Nowak, “The Idealizational Methodology and Economics. Replies to Diederich, Hoover, Janssen, Jorland and Maki," in: Idealization VI: Idealization in Economics, eds. Bert Hamminga and Neil De Marchi (Amsterdam-Atlanta, GA: Rodopi, 1994), p. 305. 
By contrast, the strengthening interaction between $A$ and $B$ in respect of $F$ occurs when the joint area of influence of the factors $A$ and $B$ on $F$ is larger than the sum of influences of the factors $A$ and $B$ exerted separately on $F$.

$$
W_{F}(A B)>W_{F}(A) \cup W_{F}(B)
$$

\section{The Cascade Effect and the Scientific Theory}

Regardless of its internal structure, a cascade of factors not only influences the transformation of the basic dependencies that the phenomenon under study was subject previously, before its occurrence, but it also imposes a transformation of the way in which theories are being formulated. Let us now put ourselves in the position of a researcher who purports to create a theory of cascade phenomena. According to ITS, every theory is a sequence of models, starting from the most abstract toward the gradually more and more realistic ones. The first model of a theory of a given phenomenon contains merely a characterization of the impact of the factor recognized as principal and disregards the influences of the factors recognized as secondary. Hence, the method of idealization is supposed to abstract a given phenomenon from the context of accidental influences and demonstrate its relations with the most essential factors. The subsequent models of a given theory gradually introduce new secondary factors. In consequence, the very theory becomes more realistic, since it begins to describe not only the basic dependencies, to which the phenomenon under study is subject, but also the disturbances and modifications introduced by the secondary factors.

The structure of theories of phenomena in which the cascade effect occurs provide a different case. In a theory describing such phenomena there is an inverted hierarchy of theoretical models - the basic model describes the influence of a cascade of secondary factors and the derivative model describes the impact of the principal factor. Because the sum of power of influence of the secondary factors forming the cascade is greater than the power of influence of the principal factor, a scientist introduces all of these factors into the very first model of the theory. In consequence, the first model of the theory of a cascade phenomenon is more realistic than the first model of the theory of phenomenon with a standard essence structure, since it comprises of more factors. The derivative model describes the impact of the principal factor that modifies merely the basic dependencies, which for the phenomenon under determination is the influence of the secondary factors occurring in a cascade.

Thus, the peculiarity of the theories of phenomena of a cascade nature is a far-reaching transformation of their structure, despite the fact that an essential 
structure of phenomena was not transformed. It is that because the power of influence of the principal factor still remained greater than the power of influence of each secondary factor taken separately.

In the process of constructing a theory of phenomena in which a cascade effect occurs, it is decisive to capture the period of time when an essential structure dominated by the principal factor transforms into an essential structure dominated by the secondary factors and identification of a factor the occurrence of which at peculiar period of time causes a cascade and "tipping the scales of influences" in the structure in favor of a set of secondary factors.

\section{The Cascade Effect and the Historical Narrative}

According to the concept presented by Nowakowa, the structure of a historical narrative reflects an essential structure of the described phenomena. ${ }^{232}$ A historical narrative consists of two layers. The surface layer records states of phenomena under investigation, whereas the deep layer refers to the determinants that decide on the type of a state. As the factors determining the behavior of the magnitude under study are ordered with respect to their essentiality, the deep layer of a narrative consists of strips. The first strip of a narrative describes the magnitude under investigation in the terms of the first model of the adopted idealizational theory. It describes the states of the phenomenon under study depending on the principal factor. The second strip of a narrative contains subtler interpretations, because it also considers the impact of the secondary factors on the phenomenon under study. Subsequent strips of a narrative contain increasingly richer interpretations of the subsequent states of a phenomenon under investigation, since they take into consideration new secondary factors that were disregarded in the initial strips of the narrative..$^{233}$

232 Izabella Nowakowa, Zmienność $i$ stałość w nauce. Przyczynek do metodologii międzyteoretycznych związków diachronicznych (Poznań: Nakom, 1991). For a discussion of various conceptions of a historical narrative, cf. Jan Pomorski, "On Historical Narration. A Contribution to the Methodology of a Research Programme," in: Narration and Explanation. Contribution to the Methodology of the Historical Research, ed. Jerzy Topolski (Amsterdam - Atlanta, GA: Rodopi, 1990), pp. 41-54; Jan Pomorski, "Wprowadzenie: spory wokół narracji historycznej," in: Metodologiczne problemy narracji historycznej, ed. Jan Pomorski (Lublin: Wyd. UMCS, 1990), pp. 11-25.

233 According to Jan Pomorski, a historical narrative reflects the viewpoint of the author, his/her philosophical assumptions, methodology and axiological perspective, see: Pomorski, “On Historical Narration," pp. 41-54. 
As a result, it is not significant what a historical narrative demonstrates, but what it omits. ${ }^{234}$ For example, a historian-materialist describing Polish history focuses on production methods, technological advancement, methods of distribution of social income, etc. He/she will account for the influence of political institutions and spiritual culture only subsequently. Differently, a historianinstitutionalist in his/her interpretation focuses on the changes in the political system, the history of dynasty and monarchy. Finally, a historian-idealist in his/ her description of Polish history will emphasize such events like: adoption of Christianity, Reformation and the rise of Protestantism, Counter-Reformation and the Baroque culture. He/she will account for the influence of economic and political factors on the Polish history only subsequently.

Compared with a narrative of the phenomena of an essential structure dominated by the principal factor, a historical narrative of the phenomena of a cascade nature has a specific peculiarity - its structure changes, despite the fact that the essential structure of the phenomenon in question does not change. This is because, due to the cascade effect, the first strip of a narrative allows for a simultaneous impact of many secondary factors, and since their common influence is greater than the influence of the principal factor. Only the second strip of a narrative considers the impact of the principal factor. Thus, a cascade narrative is already richer and closer to a historical reality in the initial strip.

In a case when interactions between factors occur in a cascade, the structure of a narrative becomes more complex. Every strip consists of two levels. The first level of a narrative describes the influence of factors present in the interactive relations of the magnitude under study. Differently, the second level in a given strip describes interactive correlations between factors by determining their range (two-factorial, three-factorial or multi-factorial interaction) and type (strengthening or weakening interaction). Thus, a narrative has to account

234 Nowakowa, Zmienność, p. 107. For the extensions of idealizational theory of a historical narrative, see: Krzysztof Brzechczyn. "Between Science and Literature. The Debate on the Status of the History," in: Idealization XIII: Modeling in History, ed. Krzysztof Brzechczyn (Amsterdam/New York: Rodopi, 2009), pp. 7-30; Krzysztof Brzechczyn, "How Do Narratives Explain? A Comment from the Point of View of Poznań School of Methodology," in: Towards a Revival of Analytical Philosophy of History. Around Paul A. Roth's Vision of Historical Sciences, ed. Krzysztof Brzechczyn (Leiden-Boston: BrillRodopi, 2018), pp. 148-165; Piotr Szwochert, "Historical Narration in the light of the Idealizational Theory of Science. A Recapitulation and Expansion," in: Idealization XIV: Models in Science, eds. Giacomo Borbone and Krzysztof Brzechczyn (Leiden/ Boston: Brill/Rodopi, 2016), pp. 299-318. 
for the factors determining a given magnitude and for the interactive relations between them.

Another significant issue concerning a narrative of a historical phenomena subject to the cascade effect is to grasp the moment of transformation of an essential structure. This is connected with the proper recognition of a type of an essential structure: does the principal factor exert the dominating influence or have the secondary factors already dominated it? The issue is also connected with an accurate identification of a particular factor that has "tipped the scales of influence" in a structure in favor of a cascade of secondary factors, and with the determination of the moment in which this has happened. There are three types of mistakes that may occur in a narrative of this type of historical phenomena: a wrong determination of the type of essential structure, a wrong identification of the factor that closes a cascade and a wrong determination of the moment in time when, under the influence of the factor initiating the domination of the secondary factors, the type of an essential structure transforms from a structure dominated by the principal factor into a structure dominated by a cascade of secondary factors.

\section{The Cascade Effect in Light of Categorial Ontology}

The cascade effect discussed through the prism of the idealizational theory of science, also leads to certain philosophical consequences. These consequences can be expressed in the language of categorial ontology. Let us now briefly present the fundamental theses of this theory, suitable for the philosophical interpretation of the cascade effect.

The theory of categorial ontology distinguishes two basic aspects of every phenomenon - its essential structure and its nomological structure. Every phenomenon has a number of determinants that affect it in a specific way. ${ }^{235}$ All factors impacting a phenomenon under investigation create a space of factors that are essential to it. A sequence of factors essential to the given phenomenon, ordered with respect to the power of influence, creates an essential structure of a given phenomenon. In that structure, one can distinguish the principal factor for a given phenomenon with the greatest power of influence, and a number of secondary factors with smaller powers of influence, as compared to the principal factor.

235 Leszek Nowak, U podstaw dialektyki marksowskiej. Próba interpretacji kategorialnej (Warszawa: PWN, 1977), pp. 51-56. 
The purport of categorial ontology is not only to reconstruct the essential structures of phenomena under study and to exhibit their possible relations, but also to reconstruct their nomological structures. ${ }^{236}$ Such structures consist of dependencies between factors and phenomena determined by them. In the above-mentioned conception, the dependency is understood as a function binding transformation of the factor recognized as essential for the given phenomenon with the transformation of the phenomenon itself. Analogically to the hierarchy of the powers of influence of separate factors, one may reconstruct the hierarchy of dependencies of the phenomenon under study - its nomological structure. The terms "inner dependency" and "regularity" refer to the dependency of the studied phenomenon on the principal factor. "Surface dependency" or the form of manifesting regularity is defined by the influence of all factors affecting the given phenomenon.

Categorial ontology predominantly deals with changes in the essential structures of the investigated phenomena. ${ }^{237}$ There are two basic types of conversions: alternations and transformations. Alternations are conversion within the realm of secondary factors, whereas transformations are conversions within the realm of principal factors of the phenomena under study.

Within the first type of conversions, three types of alternations occurring among the secondary factors. The first one is an extension. It emerges if the established essential structure is accompanied by some new secondary factors which also influenced the form of the manifestation of regularity to which so far the examined phenomenon has been subordinated. Another type of alternation is a curtailment. Under the influence of a curtailment, the repertory of secondary factors becomes limited, and the nomological structure of the phenomenon undergoes changes in the layer of surface dependencies. The third type of alteration is a replacement. It is achieved when certain factors change their place within the essential structure. The above-mentioned types of alternations of the essential structures of phenomena - an extension, a curtailment and a replacement, entail solely a modification in the form of the manifestation of a given regularity. Hence, alternations are quantitative conversions where the principal factor and thus the given regularity remain unchanged, whereas the change affects solely the repertory of the secondary factors and the form of manifestation of a given regularity.

236 Nowak, U podstaw dialektyki marksowskiej, pp. 71-76.

237 Nowak, U podstaw dialektyki marksowskiej, pp. 109-134. 
Conversions of essential structures of phenomena that cause a change of the regularity are termed transformations. Transformations are conversions in which the principal factor of a given phenomenon changes. One may distinguish two types of transformations. The transformation of the first order is a conversion where the factor that was principal in the preceding period, remains an essential factor, but it is no longer the principal factor of the given phenomenon. Differently, in the transformations of the second order, the principal factor of the given phenomenon drops out of the essential structure. Regardless of the type of transformation, each of them brings about a change in the regularity to which the given phenomenon was subject until now. Therefore, transformations belong to qualitative conversions, where a change of a principal factor changes the regularities determining the investigated phenomenon.

Let us now characterize the nature of cascade conversions in a greater detail, in light of the above-described conception. The cascade effect occurs in the domain of secondary factors; hence, it is a type of alteration. As I have previously stated, the process of accumulation of a cascade of variables relies on an enrichment of an essential structure in new secondary factors, so that a principal factor ceases to be a dominating factor. Therefore, a cascade effect is relied on an extension of an essential structure of a phenomenon under study. Under the impact of interactive relations between factors appearing in the cascade, an internal replacement of an essential structure may occur. Under the impact of an interaction with a number of other factors, certain factors increase their influence on the phenomenon under investigation, while others decrease their influence under the impact of the interaction. Hence, a cascade change is an extension of an essential structure combined with its internal replacement.

Let us recall that, in light of the above-mentioned theory, isomorphism occurs between the changes in an essential structure and the changes in a nomological structure. Quantitative conversions (alterations) lead to the changes of the manifestations of regularity, whereas qualitative conversions (transformations) lead to changes in the regularities themselves. The peculiarity of the cascade derives from the fact that the defined type of quantitative change (an extension, which may be connected with a replacement) entails a change of the regularity itself rather than the change of manifestation of regularity. In this case, hence, the principle of isomorphism of conversions between a nomological structure and an essential structure is falsified.

It seems that it is certain tacitly adopted idealizing assumptions of categorial ontology that are responsible for this state of affairs. These assumptions presume that there exists only one single type of essential structures, namely such in which the principal factor is the dominating factor. In fact, in the realm of 
that type of essential structures, isomorphism occurs between the conversions of essential and nomological structures of the phenomenon under study. However, isomorphism does not arise in the realm of essential structures, in which the sum of power of influence of the secondary factors is greater than the power of influence of the principal factor.

\section{The Rationale of Idiographism in the History}

The cascade effect also allows a consideration of the above-discussed methodological conversions between idiographic and nomothetic understanding of history in different light.

A classic justification of the presence of idiographism in the historical sciences was put forward by Wilhelm Windelband. He differentiated between two basic types of sciences. The natural sciences are supposed to aim at revealing the general and the universal, whereas the task of historical sciences is to present the individual and the particular. This standpoint was developed by Windelband's student and follower, Heinrich Rickert and other thinkers representing the group of German anti-naturalistic philosophy.

The claims of idiographism caused a vivid discussion also in the domain of Polish methodology of history and were forced to face contradictory interpretations. For instance, in the interpretation put forward by Adam Schaff, the idiographic stand in the domain of the social sciences is supposed to deny the existence of scientific laws. ${ }^{238}$ The negation of the existence of the laws of social evolution arises from the conviction that the social sciences focus on the issues of an individual and unique character. In consequence, there are no regularities in the social world and it is impossible to discover them. Iija Lazari-Pawłowska criticized the above interpretation of the idiographic stand. According to her, the theses of an idiographism have a methodological character, since they describe what is done by historians:

[T]he methodological thesis put forward by the representatives of the theory of the idiographic approach concerns the structure of sciences, not the structure of reality. It is important to emphasize that this thesis is of a descriptive character, and not of a normative one, since it states what the researchers-historians actually do, and not what they are supposed to do. ${ }^{239}$

238 Adam Schaff, Obiektywny charakter praw historii (Warszawa: PWN, 1955), p. 55.

239 Iija Lazari-Pawłowska, "Idiograficzna koncepcja historii," Studia Filozoficzne, No. 1 (1958), p. 15. 
As it usually is in the case of similar discussions, the term "idiographic" has been used in various meanings. For Andrzej Malewski and Jerzy Topolski, the fundamental difference between the idiographic and the nomothetic method of historical research is the way in which the statements concerning reality are formulated. ${ }^{240}$ The historical sciences include two basic types of statements: a lawlike statement and a historical statement. A lawlike statement is a scientific law that informs about constant dependencies between events. Such type of statement should not have any spatial-temporal indicators or proper nouns. An example of a lawlike statement from an area outside of the social sciences is the following statement: ice turns into water in the temperature above $0^{\circ} \mathrm{C}$. An example of a lawlike statement from the area of the social sciences is the following statement: prizes motivate people to work. A scientific law is a justified lawlike statement with constant relations between phenomena, belonging to a particular scientific field, without any spatial-temporal indicators or proper nouns. A historical statement is an opposite of a lawlike statement. This type of a statement openly or covertly includes spatial-temporal indicators, while including proper nouns. An example of a historical statement are the following opinions: "Mieszko I of Poland was baptized in 966," or "the manorial-serf system became widespread in the countries east of river Elbe between the 16th and the 17th centuries." A historical generalization is a third, mixed type of statement. It discusses constant dependencies between phenomena, however, it locates them in a defined time and space. For example, the following statement is a historical generalization: "every country where the manorial-serf system has been spreaded, experienced a decay of towns in the 16th-18th century." The above statement discusses dependencies between phenomena, but it locates them in a particular time and space.

Based on the differentiation between general statements and historical statements, Malewski and Topolski define two research methods applied to a historical reality:

Historians describe some subject in a purely idiographic way if the results of their investigation take the form of historical statements. Historians describe some subject in a way which is purely nomothetic if they subordinate all of their research to the aim of

240 Andrzej Malewski and Jerzy Topolski, Studia z metodologii historii (Warszawa: PWN, 1960), pp. 21-22; cf. the English version: Andrzej Malewski and Jerzy Topolski, "The Nomothetic versus the Idiographic Approach to History," in: Idealization XIII: Modeling in History, ed. Krzysztof Brzechczyn (Amsterdam/New York: Rodopi, 2009) pp. 299-301. 
substantiating some laws of science and treat historical statements exclusively as premises used to substantiate these laws. ${ }^{241}$

According to Malewski and Topolski, the idiographic viewpoint is present in the historical sciences in three variants. The idiographic approach toward this issue concerns whether:

the subject of historical inquiry can be investigated in an exclusively idiographic way. By the subject of historical inquiry we mean people's action, because it is those actions which principally constitute the historical process. Therefore, the point is whether human actions, whose history is the subject of historians' inquiry, are such that they preclude any laws and thus should be described exclusively by means of historical statements. ${ }^{242}$

Another variant of the idiographic approach focuses on the scientific historical practice. It deals with the issue whether:

researchers focusing on the realm of history conduct their research exclusively in an idiographic way, i.e. whether they are preoccupied exclusively with establishing historical statements, and never with laws of science. The affirmative answer to this question translates into the view that in fact historians by and large do not occupy themselves with establishing laws of science and instead deal exclusively with establishing historical statements. Such a view will be called the thesis of the idiographism of scientific research. $^{243}$

The third type of the idiographic approach, termed by Malewski and Topolski, "the program of scientific idiographism" ponders on whether "it is desirable that historians should be preoccupied exclusively with formulating historical statements, leaving the task of a possible formulation of laws of economics to socio-psychologists and sociologists."244

Let us now paraphrase the differences between nomothetism and idiographism, in terms of categorial ontology constituting the body of the ITS assumptions. The set $U$ of all objects, which encompasses the magnitude $F$ with certain intensity, makes up the universe of a given magnitude. Let us assume that in this universe we can distinguish particular subsets $Z_{A^{\prime}} \ldots, Z_{N^{*}}$. These sets are $F$-species; and the sum of $F$-species of the same principal factor forms a genus of a given magnitude in its scope. Hence, $F$-genera vary among themselves with respect to the distinguished principal factor, whereas $F$-species belonging

241 Malewski, Topolski. “The Nomothetic," p. 305.

242 Malewski, Topolski. “The Nomothetic," p. 306.

243 Malewski, Topolski. "The Nomothetic," p. 306.

244 Malewski, Topolski. “The Nomothetic," p. 306 
to the same $F$-genus differ with respect to the secondary factors. In consequence, $F$-genus is a sum of the $F$-species that share a principal factor. This differentiation can be illustrated by a scheme. Let us assume that there are essential structures of the following shape:

$$
\begin{aligned}
& S_{F}^{Z 1}: H \\
& H, p \\
& S_{F}^{Z 2}: H \\
& H, q \\
& S_{F}^{Z 3}: G \\
& \text { G, } q
\end{aligned}
$$

Each of the sets $Z^{1}, Z^{2}, Z^{3}$ constitutes an example of $F$-species. Additionally, the factor $F$ has two $F$-genera. Genus $R^{1}$ is identical with the sum of classes $Z^{1}$ and $Z^{2}$, and genus $R^{2}$ is identical with the class $Z^{3}$.

Using the conceptual apparatus of the above-discussed conception, one can paraphrase the theses of idiographism and nomothetism by distinguishing between two variants for each of the two standpoints.

Radical idiographism pronounces that each $F$-kind to be a one-element set. It has significant methodological consequences, since it means that the magnitude $F$ has a separate essential structure on every object, and that an independent theory should be constructed for the magnitude $F$ on every object.

Radical nomothetism, in turn, claims that universe of each magnitude $F$ contains only one $F$-kind. It follows that there is one only one principal factor for the magnitude $F$, ascertained on all objects. A moderate standpoint (moderate idiographism or nomothetism) presupposes the existence more than one F-kind in that universe, but less than the number of elements of the universe.

At this point, a certain simplification is worth mentioning. Scientists usually do not investigate essential structures of singular factors, but attempt to examine particular distinguished entities. ${ }^{245}$ These entities, termed categorical systems, are characterized by the situation that their constituent factors are the principal factors for themselves. However, in order to avoid further complication, I will assume that the object of scientific research is an essential structure of a single magnitude, and not of complexes of magnitudes.

The cascade effect also sheds a new light on the opposition between the radically conceived idiographism and nomothetism. The phenomenon allows to sort out a certain rational core from the ideographical approach to history (in its radical version). As we have seen, every cascade is an unrepeatable and unique combination of factors that hardly ever appear in the same configuration. Even if a given configuration of cascade factors recurs, they may still vary with respect

245 Leszek Nowak, “On the (Idealizational) Structure of Economic Theories," Erkenntnis, No. 30 (1989), pp. 232-233. 
to the accumulation rate of secondary factors and with respect to which of its components initiate and which close the cascade. Therefore, in practice, each cascade is a unique combination of factors. The cascade effect justifies the thesis of the radical objective idiographic approach, since, for each cascade, a separate essential structure has to be established. Additionally, the cascade of factors transforms the structure of a scientific theory and influences the method of construction of a historical narrative. In a theory explaining the phenomena of a standard essential structure, the first model describes the influence of the principal factor and the derivative models explain the influence of the secondary factors. In the case of a theory describing phenomena of a cascade essential structure, the situation is reversed. Here, the first model contains a description of the impact of secondary factors and only the derivative model demonstrates the influence of the principal factor. In the structure of a historical narrative corresponding changes occur. The first strip of a narrative of phenomena falling under the cascade effect demonstrates the impact of secondary factors. The second strip presents the impact of the principal factor. Changes caused by the cascade effect in the structure of a scientific theory and a historical narrative justify, to a certain degree, the intuitions of scientific and normative idiographic research attitude.

However, the scope of the applicability of the basic intuitions of the radical idiographic research attitude is not unlimited. Despite the fact that the particular configurations of cascade factors are unique, they can be subsumed to a general type - the type of a cascade. Moreover, the effect may appear merely in a particular kind of essential structures, namely in those in which the joint powers of influence of secondary factors is greater than the power of influence of the principal factor. Therefore, adequately paraphrased theses of the radical idiographic approach are restricted only to phenomena of such type of essential structure. It becomes evident from a particular theoretical perspective assuming a nomothetic approach to history.

The fact that at least some of the intuitions of the idiographism can be incorporated into the body of statements of the contrary methodological standpoint, indirectly proves against the idiographism, becoming an argument in favor of the nomothetic approach to history.

\section{The Cascade Effect and Economic Dualism in Modern Europe}

In the present book, I will apply the above-introduced approach to explain the developmental dualism in the evolution of European society. It appears that the difference of the developmental lines of the societies of Central and Western 
Europe is a result of a cascade effect. Analogical courses of development of both parts of Europe, Western and Central, in the 13th-15th centuries - the expansion of towns, the creation of the monetary economy, the transition from serfdom to rent and the gradual weakening of the feudal control over the peasantry since the 16th century - had been replaced with a growing developmental distinctiveness of the Central Europe. In this part of Europe, east of the river Elbe, the towns witnessed a crisis, second serfdom was introduced and the superiority of the nobility over peasantry was reinforced. This course of the evolution in Central Europe relied on a number of secondary factors that jointly caused a suppression of the developmental regularities manifested in the Western Europe. We may assume that we are dealing with a cascade effect. In the further part of the present book, based on considerable literature, I will characterize the factors that determined the dissimilarity of the developmental lines of Western and Central Europe. 



\section{Part III Theoretical Assumptions}





\section{The Basic Ideas of Non-Marxian Historical Materialism}

\section{Presentation of Basic Ideas}

\subsection{A Typology of Societies}

According to non-Marxian historical materialism, class divisions are emerged not only in economy but also in other fundamental domains of the public life: politics and culture. ${ }^{246}$ These three spheres of public life, or social material momenta: culture, politics, and economy, have parallel internal structures comprised of material, institutional, and consciousness levels. ${ }^{247}$ The material level

246 Leszek Nowak, Property and Power. Towards a Non-Marxian Historical Materialism (Dordrecht: Reidel, 1983), pp. 169-186.

247 The present chapter offers a drastically simplified presentation of the core of nonMarxian historical materialism. The selection of some dimensions and motifs of this theory serves the interpretation of the evolution of Central-European societies. For a complete presentation, see: Leszek Nowak. U podstaw teorii socjalizmu, Vol. 1: Własność i Władza. O konieczności socjalizmu; Vol. 2: Droga do socjalizmu. O konieczności socjalizmu w Rosji; Vol. 3: Dynamika władzy. O strukturze i konieczności zaniku socjalizmu (Poznań: Nakom, 1991) and in English: Nowak, Property and Power; Nowak, Power and Civil Society. Extensions and a different application of this theory are included in the following volumes published in Polish: Jerzy Brzeziński and Krzysztof Łastowski, eds., Filozoficzne i metodologiczne podstawy teorii naukowych (Poznań: PWN, 1989); Leszek Nowak and Piotr Przybysz, eds., Marksizm, liberalizm, próby wyjścia (Poznań: Zysk i S-ka, 1997); Krzysztof Brzechczyn, ed., Ścieżki transformacji. Ujęcia teoretyczne i opisy empiryczne (Poznań: Zysk i S-ka, 2003); Krzysztof Brzechczyn, Mieszko Ciesielski and Eliza Karczyńska, eds., Jednostka w układzie społecznym. Próba teoretycznej konceptualizacji (Poznań: Wyd. Naukowe WNS UAM, 2013); and in English: Piotr Buczkowski and Andrzej Klawiter, eds., Theories of Ideology and Ideology of Theories (Amsterdam: Rodopi, 1986), Leszek Nowak, ed., Dimensions of the Historical Process (Amsterdam-Atlanta, GA: Rodopi, 1989); Leszek Nowak and Marcin Paprzycki, eds., Social System, Rationality and Revolution (Amsterdam-Atlanta, GA., Rodopi, 1993). On non-Marxian historical materialism, see: Jerzy Topolski, "Refleksje o systemie historiozoficznym nieMarksowskiego materializmu historycznego," in: Ścieżki transformacji. Ujęcia teoretyczne i opisy empiryczne, ed. Brzechczyn (Poznań: Zysk i S-ka, 2003), pp. 279294, Waldemar Czajkowski, "Kilka uwag o Leszka Nowaka nie-Marksowskim materializmie historycznym i Andre G. Franka teoriach systemu światowego," in: Jednostka w układzie społecznym. Próba teoretycznej konceptualizacji, ed. Krzysztof 
of political life includes the means of coercion - weaponry, prisons, police bats, etc. The relation to the above means determines a division into two social entities: the class of rulers, which controls the means of coercion, and the remaining civil class. These two great collective entities are organized into institutions, such as political parties, social organizations, associations, etc., that channel social activities performed by various groups of people. The above-listed organizations form an institutional level of politics. Still, a consciousness level of politics includes ideological doctrines and political programs, which motivate the members of this aspect of public life to adopt and accept certain social roles.

Economy has an analogical internal structure. Correspondingly to the case of politics, the material level of economy includes the means of production, which determine a division into two classes: owners and direct producers. Trade unions, employers' organizations, consumer associations, etc. establish the institutional aspect of economy. At the same time, however, the consciousness level of economic life includes doctrines and economic viewpoints that provide a justification for significant actions undertaken by social groups within the domain of public life.

In a corresponding manner, the cultural domain comprises three abovementioned levels: material, institutional, and consciousness-related. The means of spiritual production - printing press, radio, television, etc. - constitute the material level. The relation of to them determines a division into two social classes: priests (secular and religious who decide on the purpose of the means of spiritual production and believers who do not have such possibilities. The institutional level of spiritual life comprises organized castes of priests: churches, universities, writers' associations, creative organizations, etc. The aspects of the diffused world-view doctrines, which provide a justification of actions, undertaken by particular castes of priests forms a meta-consciousness level of spiritual life. Following from this, a given worldview is scientific, since it includes only the true interpretation of the revelation provided by God; it is "civilized", in contrast to the opposed "barbaric" standpoints.

For this reason, the above-mentioned division of public life brings about a distinction between three separate types of class divides. In the domain of politics, the class of rulers, having the means of coercion at its disposal, enlarges the global sphere of influence, thereby restricting the autonomy of citizens. In the economical sphere, the class of owners, having the means of production at its

Brzechczyn, Mieszko Ciesielski and Eliza Karczyńska (Poznań: Wyd. Naukowe WNS UAM, 2013), pp. 187-206. 
disposal, is able to maximize the surplus product to maximum, at the expense of producers' direct profit. In the cultural domain, the castes of priests, which monopolize the control over the mass media, increase spiritual indoctrination, thereby reducing the autonomy of the believers. Social antagonisms - which result from the unequal access to the material means of coercion, production, and indoctrination in each of the three spheres of public life - have an autonomous character. Social divisions present within other aspects of public life may only weaken or reinforce these antagonisms. Moreover, class divisions may accumulate. A given social class, in order to increase its social power, may acquire control over the means of coercion and production, or the means of coercion and spiritual indoctrination, etc.

For non-Marxian historical materialism, social divisions are founded on access to material social means. Based on this criterion, it distinguishes between class societies with individual classes and supra-class societies with overlapping classes.

There are several types of class societies distinguished with respect to which of the social classes prevails - rulers, owners, or priests. The dominance of one class over another means that, for instance, the social interest of class $A$ dominates over the social interest of class $B$ and when a conflict of interests occurs, the interest of class $A$ is to maximize in a long-term. A principal social class dominates over the remaining classes in the following way: providing a conflict of interests occurs, the social interest of a principal class is to maximize in a long-term. ${ }^{248}$

Within supra-class societies, one could distinguish totalitarian societies with a double class of rulers-owners and fascist societies with the double class of rulerspriests. Each of the above-described types of societies may exist in a number of variants distinguished with respect to a domineering type of class interest and an instrumental type of class interest. For example, in a $P$-totalitarian society, rulers-owners maximize political control and subjugate a maximization of profit to reinforcing power. In an $E$-totalitarian society, an increase of political control is subordinated to the maximization of profit. One may also distinguish a balanced

248 This is a modification of a definition put forward by Nowak, see: Nowak, U podstaw teorii socjalizmu, Vol. 1, p. 176. One may also paraphrase the definition of estate society in terms of $\mathrm{n}-\mathrm{Mhm}$. It is a class society with individual classes of rulers, owners and priests. A class of owners is divided into two layers: a sub-class of owners of means of production of the old sphere and a sub-class of owners of means of production of the new sphere. Such society is a balanced society with each class controlling material social means - rulers, priests, and owners of means of production in both spheres may implement their class interests evenly. 
variant of the above-mentioned type of society, where both social interests - an increase of political control and an increase of profit - are implemented evenly.

Finally, there is a socialist society with a social class in control of the means of coercion, production and indoctrination. There is a number of variants of this type of society depending on which type of class interest holds priority and which is instrumental. A priority of class interest $A$ over class interest $B$ means that providing a maximization of the interest $B$ collides with a maximization of interest $A$, in a long-term perspective interest $A$ is maximized. In other words, class interest $B$ is instrumentally subjugated to a maximization of social interest $A$. Following from this, the principal class interest in a given society implemented by a triple-class of social potentates is the class interest that holds priority, as understood in the above terms, over the remaining two, let us call them, derivative class interests.

For instance, in a hierocratic variant of a socialist society, the fundamental interest of a triple-ruling class is to maximize spiritual dominion, thereby instrumentally subjugating control over the means of coercion and production to an increase of spiritual power. An economic variant of a socialist society occurs when a ruling class maximizes the surplus product to. As a result, an expansion of power and spiritual authority is instrumentally subjugated to a maximization of profit. At the same time, however, in a political variant of a socialist society, the ruling class maximizes political control. The remaining two types of social interest, a maximization of profit and spiritual domination, are instrumentally subjugated to a maximization of power. One may also distinguish a balanced variant of a socialist society where the ruling class evenly maximizes three types of class interests: power, profit, and spiritual domination.

Furthermore, supra-class societies may be divided into pure supra-class societies and quasi-supra-class societies. The latter group of societies comprises of double-classes and single-classes. For example, in a quasi-socialist society there exist separate single classes of rulers and of priests, besides a triple-ruling class. ${ }^{249}$

249 For a development of the presented typology, see: Krzysztof Brzechczyn, O wielości linii rozwojowych $w$ procesie historycznym. Próba interpretacji ewolucji społeczeństwa meksykańskiego (Poznań: Wydawnictwo Naukowe UAM, 2004), pp. 73-86; Mieszko Ciesielski, "Problem kumulacji podziałów klasowych we współczesnym kapitalizmie. Próba interpretacji teoretycznej," in: Jednostka w układzie społecznym. Próba teoretycznej konceptualizacji, eds. Krzysztof Brzechczyn, Mieszko Ciesielski and Eliza Karczyńska (Poznań: Wyd. Naukowe WNS UAM, 2013) pp. 131-152; Tomasz Zarębski, "Struktura klasowa społeczeństw hydraulicznych. Próba parafrazy teorii Karla Augusta Wittfogla w aparaturze pojęciowej nie-Marksowskiego materializmu historycznego," in: Jednostka w układzie społecznym. Próba teoretycznej 


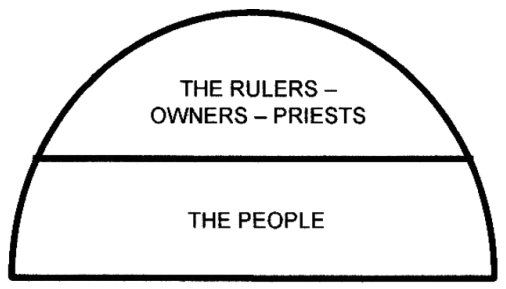

socialist society

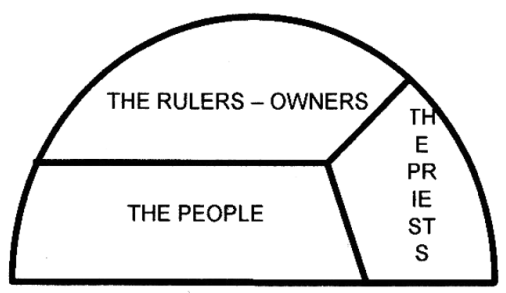

P-totalitarian society

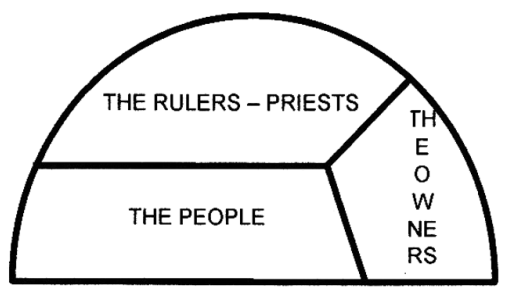

fascist society

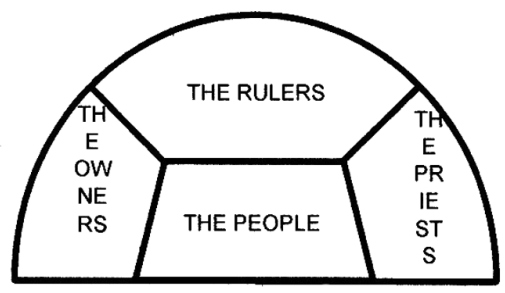

the class society

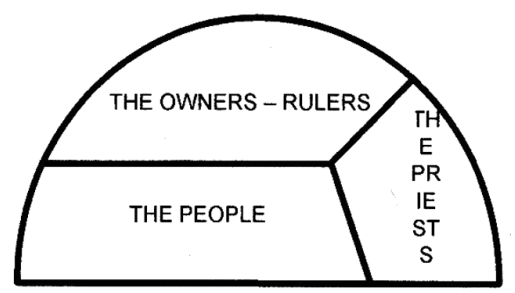

E-totalitarian society

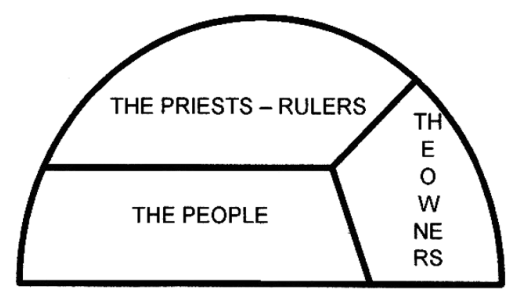

theocratic society

Fig. 6: Basic types of societies in non-Marxian historical materialism.

\subsection{A Model of Evolution of a Purely Political Society}

Let us now outline a given part of non-Marxian historical materialism, namely the theory of a socialist society, which will serve as an example here. The initial model of that society is theory of political power. Let us now recapitulate the main 
theses of the model. ${ }^{250}$ The theory of political society comprises a static part that illustrates relations between the political authorities and a class of citizens, and a dynamic part that investigates the evolution of these relations over time. The static part of the theory of power consists of three kinds of presumptions about:

(i) mechanism of political competition;

(ii) tendency of gradual revitalization of autonomous social ties;

(iii) dependency between civil alienation and level of political resistance.

A political society is divided into three social layers: rulers who are in control of the means of coercion, citizens do not control of the means of coercion and servants. In order to present this structure more systematically, let us assume that there are three persons: $A, B$ and $C$. Person $A$ controls a given fragment of the sphere of activity of person $B$, hence $B$ is subjugated to person $A$. A situation is possible where person $B$ controls a segment of activity of person $C$ who is subjugated to $B$. If voluntary subjugation of person $B$ to person $A$ is required to subjugate person $C$ to person $B$, than individuals $A, B, C$ form a chain of dominance. This chain is founded on a tender consisting in a resignation from a part

250 For a complete basic model of a political society, see: Nowak, Power and Civil Society, pp. 21-46, 55-67. Presently the theory of political power is a multi-model conception, which takes into account the influence of state political systems and organizations of civil society, political awareness, external aggressiveness, and technical advancement with respect to the means of coercion, link between the coercive force and the authorities, and rivalry between fractions, on the evolution of the political system. For subsequent developments of the conceptions investigate the impact of ineffective conquest and subordination on the evolution of a political society, see: Krzysztof Brzechczyn, "Unsuccessful Conquest and Successful Subordination. A Contribution to the Theory of Intersocial Relations," in: Social System, Rationality and Revolution, eds. Leszek Nowak and Marcin Paprzycki (Amsterdam - Atlanta, GA: Rodopi, 1993), pp. 445456, various types of political systems (two- and multi-party), see: Tomasz Banaszak, "Problem autokratyzacji ustroju demokratycznego," in: Marksizm, liberalizm, próby wyjścia, eds. Leszek Nowak and Piotr Przybysz (Poznań: Zysk i S-ka, 1997), pp. 381399 and Marcin Połatyński, "O koalicji i rozłamie partyjnym. Przyczynek do teorii sub-społeczeństwa partyjnego w nie-Marksowskim materializmie historycznym," in: Jednostka w układzie społecznym, eds. Krzysztof Brzechczyn, Mieszko Ciesielski and Eliza Karczyńska (Poznań: Wyd. Naukowe WNS UAM, 2013), pp. 153-160, or the role of secret police in the political system, see: Krzysztof Brzechczyn, "Tajna policja polityczna w systemie totalitarnym. Próba modelu," in: W stronę antropologii bezpieki. Nieklasyczna refleksja nad aparatem bezpieczeństwa w Polsce Ludowej, eds. Jaroslaw Syrnyk, Agnieszka Klarman, Marcin Mazur and Eugeniusz Kłosek (Wrocław: IPN, 2014), pp. 31-50. 
of personal freedom in exchange for a possibility to enslave others. Following from this, the class division to rulers and citizens does not correspond with the division into those who rule and those who are ruled by others. The criterion of being a ruler is purely materialistic - a ruler controls the means of coercion, and a citizen does not control them. The criterion of being a servant is relative - a servant participates in the structure of subjugation.

In the enough large hierarchized class of rulers, the mechanism of political competition enforces a typical ruler regardless of his personal view to increase his/her sphere of influence. Otherwise a given ruler would lose his position in the power structure. There are two principal means of control over the class of citizens: terror and bureaucracy. Terror is a physical elimination of citizens who form centers of social state-independent ties, and bureaucracy consists in substitution of autonomous social relations of a citizen-citizen type with etatized social relations of a citizen-ruler-citizen type. As a result, authorities gradually infiltrate the structure of public life and, in consequence, it becomes impossible for citizens to undertake social actions without their consent.

It is assumed that the actions of a citizen are guided by a set of preferences. Civil actions include regulated and autonomous actions. A citizen undertakes a regulated action in response to a sanction (or threat of it) imposed by a ruler. Autonomous actions are undertaken without threat of repression made by rulers. As a result of the mechanism of political competition, the field of civil autonomy is shrinking and the field of regulation enlarges.

If the level of subjugation reaches a certain threshold, there appears a tendency in a society to gradually revalorize autonomous civil ties. Bureaucratic social ties, where the authorities adopt the role of an intermediary, are substituted with autonomous social ties, not intermediated by interfering authorities, i.e. information control brings about a boom in gossip; economic control causes an emergence of a "black market;" and introduction of control into public life results in the appearance of informal and conspiratorial organizations. As a result, when "almost all" civil actions are controlled by the political authorities, the tendency to revalorize autonomous social ties brings about an outburst of a social protest.

According to the third kind of static presuppositions, the level of civil resistance depends on the number of actions controlled by political authorities. The ratio of the number of regulated actions to the total number of actions undertaken by citizens (the universe of action) is called civil alienation. It is assumed that intensity of civil resistance depends on the level of civil alienation and can be presented as follows: 


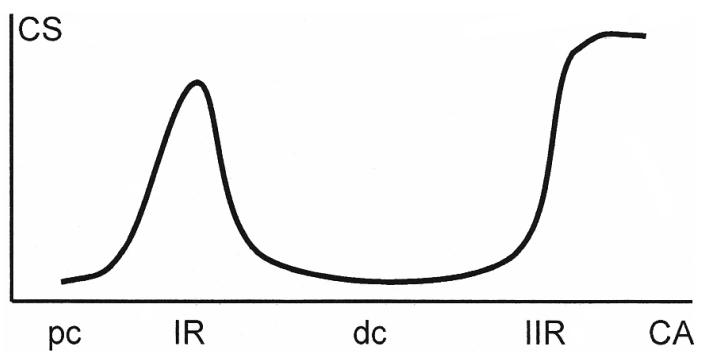

Fig. 7: The dependence of the level of the class struggle of the citizenry on civil alienation Explanations: $C S$ - level of political class struggle, $C A$ - level of civil alienation, $p c$ - interval of class peace, $I R$ - revolutionary area of the first type, $d c$ - the interval of declassation, $I I R$ - revolutionary area of the second type.

- when the number of regulated action is low (and thus civil alienation is also low), social peace prevails, because citizens have no reason to rebel;

- when civil alienation is moderately high, a political revolution of the first kind breaks out: the political control becomes painful for citizens, but does not diminish an ability of citizens to cooperate and resist;

- when the level of civil alienation is high, social peace also prevails because atomized citizens are unable to resist;

- when civil alienation is extremely high, appears the tendency of gradual revalorization of autonomous civil bonds that lead to an outbreak of political revolution of the second kind.

Let us now investigate an evolution of the relation between authorities and a class of citizens. The first model of political society in n-Mhm is based on a set of idealizing assumptions. ${ }^{251}$ The modeled political society $S$ :

(a-i) is divided into only two political classes of rulers and citizens; as a result, the model disregards a differentiation of the investigated society into economic and spiritual classes;

(a-ii) is isolated from the outside;

(a-iii) technological level of means of coercion is constant;

(a-iv) rulers apply the means of coercion directly;

(a-v) the influence of political institutions into socio-political processes is disregarded;

(a-vi) the influence of political consciousness is disregarded.

251 Nowak, Power and Civil Society, pp. 49-54. 
Let us assume that at the onset of the phase of growing civil alienation class peace prevails in the relations between rulers and citizens. Subsequently, a typical ruler decides to broaden the scope of public life under his/her influence, in response to the competition between those in control of the means of coercion. Rulers who refuse to react in the above way are being eliminated from the power structure, or finally increase their domain of influence. As a result, the enslavement of servants, who have already been dependent on rulers, increases and they respond with subjugation of citizens who have until then remained free. In consequence, the sphere of civil autonomy is reduced and the global level of civil alienation increases. The increased political resistance of citizens gradually transforms into an open political revolution and the system enters the phase of the revolution of the first kind.

A revolutionary engagement may conclude with a defeat of citizens or their victory. In the first case, after crushing a revolutionary movement, authorities introduce a post-revolutionary terror. Initially, it is directed against the citizens who formed centers of state-independent social ties. The atomization of a civil class allows the authorities to increase control over public life, since, in the situation of declassation, disappears the resistance of citizens, which is the only factor capable of restraining the pressure of authorities.

A victorious political revolution of the first kind does not bring about any significant changes, since a revolutionary elite transforms into a budding new class of rulers. This new class controls of the revolted masses and, moreover, of the armed paramilitary units that, in fact, soon become the seed of forces of coercion. Subsequently, under the mechanisms of political competition, the members of a new class of rulers maximize their control over citizen's action. Idealistic revolutionists, who do not aim to increase their influence, are being eliminated from the political structure or in time learn how to take care of their (material) interests. As a result of the above-described social processes, the domain of state control increases once more bringing about an increase of social resistance. The latter transforms into another revolution and closes a civil loop. A civil revolution of the first kind - this time directed against the new class of rulers - once more faces two outcomes: victory or defeat. A lost revolutionary movement brings about a post-revolutionary terror, while victory once more leads to a civil loop. In consequence, after a series of civil loops, one of the subsequent revolutions is crushed and a declassation of citizens follows.

In the phase of enslavement, a declassation of citizens allows rulers to increase their spheres of influence without facing a social resistance. When almost all spheres of public life are controlled by the rulers, the system enters the state of total enslavement. In this sub-phase of a evolution there are no 
autonomous social spheres open to subjugation. The mechanisms of competition for power continue to force a typical ruler to increase his/her sphere of influence and, in turn, political competition progresses at the expense of the spheres of public life that have already been subjugated to other members of power hierarchy. Initially, political competition targets the spheres of influence subjugated to servants, subsequently, the spheres subjugated to individual rulers. The state over-competition in the conditions of the model would lead to a destruction of the entire system of power. The only way to weaken the mechanisms of competition and to sustain the political structure are purges that eliminate the surplus of candidates for power. Their victims in the first order are servants, and in the second order - rulers who take the lowest position in the power hierarchy. The areas of social life abandoned by them are then subjugated by new candidates for power. Following from this, a sub-phase of power self-enslavement is characterized by periodic purges that interrupt the periods of total enslavement.

The above-described vicious circle of purges and self-enslavement of power is interrupted by a growing ability of a civil class to resist. Gradual revalorization of autonomous social ties brings about an outburst of a civil revolution of the second kind, one which allows the authorities to extricate from the mechanism of purges and establishing new relations between rulers and a civil class, with a reduction of political control at its core. Rulers crush the revolution and repress its participants, however, in order to avoid another revolution, they agree to introduce concessions to the civil class. The decrease of political control brings about emergence of an autonomous civil domain that may become subject to enslavement by rulers. As a result, the threat of power self-enslavement is eliminated.

However, after a certain time, the mechanisms of political competition bring about a secondary increase of civil alienation. In the phase of cyclical declassations, the growth of political control causes an outbreak of another revolution of the second kind of a broader social base and enforcing substantially greater concessions on the part of authorities. A political society evolves according to the following pattern: revolution of the second kind - declassation concessions - increase of political control - another revolution of the second kind of a broader social base - declassation, etc.

The rebirth of civil society brings about an increase of the number of citizens participating in political revolutions. This, in turn, leads to a mass revolution that forces authorities to introduce concessions instead of repressions and, moreover, these concessions have to be so significant that they bring about a class compromise. In the phase of cyclical revolutions of the second kind, the mechanism of social evolution transforms into the following pattern: revolution of the 


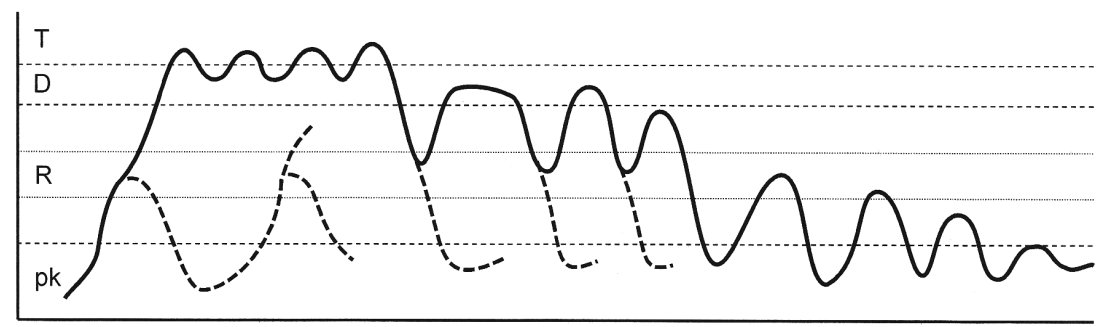

Fig. 8: An evolution of a purely political society. Explanations: $p k$ - threshold of class peace, $R$ - revolutionary area, D - threshold of decclassation; T - threshold of totalization; the dotted line indicates a civil loop.

second kind - concessions - increase of political control - another revolution of the second kind of a broader social base - concessions of a broader scope. The cycle of revolutions continues until the system reaches the stage of class peace characterized by a level of political control acceptable to a civil class. ${ }^{252}$

\subsection{The Global Model of a Political Society}

In the following section of the book, I shall present a concretization of a basic model of political society. One of the idealizing assumptions (a-ii) - the assumption concerning isolation of a political society under investigation will be removed. ${ }^{253}$ The model iv includes an inter-social system (I will also use the term "country" due to stylistic reasons) consisting of a domineering society and a number of conquered societies that have a similar social structure and that fulfil all of the previously adopted idealizing assumptions (i and iii-vi). To sum up: they are two-class societies comprising of rulers and citizens, with a constant level of the means of coercion directly controlled by the rulers, and deprived of political institutions and political doctrines.

252 For alternative models of the final stages of the socio-political development, see: Krzysztof Brzechczyn, "Civil Loop and the Absorption of Elites," in: Social System, Rationality and Revolution, eds. Leszek Nowak and Marcin Paprzycki (Amsterdam Atlanta, GA: Rodopi, 1993), pp. 277-283, Grzegorz Tomczak, "Is It Worth Winning a Revolution," in: Social System, Rationality and Revolution. Poznan Studies in the Philosophy of the Sciences and the Humanities, Vol. 33, eds. Leszek Nowak and Marcin Paprzycki (Amsterdam - Atlanta, GA: Rodopi, 1993), pp. 265-276.

253 Nowak, Power and Civil Society, pp. 123-148. 
A successful aggression and conquest of foreign societies brings about an extraordinary (external) increase of sphere of regulation. The aggressiveness of a political system understood as such is not its permanent feature, but it is manifested in certain phases of evolution of a political society. In the development of a political society, it is possible to distinguish two ranges of aggressiveness. A political society enters the first range of aggression in the final stadium of the phase of growing civil alienation - from the threshold of class peace to the phase of revolution of the first kind. In that stage, the extraordinary rise of external sphere of regulation allows for stabilization of internal relations and dismissal of the threat of a civil revolution. A political society enters the second range of aggression in the phase of enslavement. At this stage of a social evolution, the extraordinary rise of external sphere of regulation postpones the threat of power self-enslavement.

It is noteworthy to devote the following paragraph to the conquered country. As a result of foreign subjugation, its citizens become declassed. Conquest has the same consequences as a crushed civil revolution, since it shifts the victim backwards to the phase of enslavement, regardless of its current evolution stage.

Let us now present a course of evolution of an empire. In the phase of growing civil alienation there is social peace in a society $S$. However - as a result of the mechanism of political competition - rulers increase the internal sphere of regulation. In consequence, civil alienation and in consequence - civil resistance increases. Rulers conquer a society $S^{\prime}$ in order to postpone the risk of social unrest. In consequence, a political system enters the first range of aggression. After a successful conquer, a budding imperial system is created, comprising of a metropolis and a subjugated province. Enslavement of provincial citizens allows the imperial rulers to maintain social peace in the metropolis. Although not for long. After a certain time, a conquered society is declassed and profits gained with the aggression end. Rulers are forced to launch another aggression or to increase political control in the metropolis, risking an outburst of resistance of the largest segment of a civil class. By conquering subsequent societies, rulers dismiss the threat of outbreak of a revolution in the metropolis. After some successful conquests, an imperial system was emerged, consisting of a metropolis and a number of provinces. This empire has a benevolent center, since the citizens of the metropolis are less enslaved, in comparison to the citizens of the provinces.

After a certain time - in a situation of a given level of the means of coercion, the resistance of provincial citizens and the enslavement of metropolitan citizens 
who gradually become unsuitable for the role of an imperial policeman - the empire runs out of the possibilities of growth. Moreover, a number of provincial sub-societies reach the threshold of civil awakening, exit the state of enslavement and enter the phase of cyclical declassation. Since then, imperial rulers begin to increase the scope of political control in the metropolis. An increase of civil alienation brings about a growing opposition of the metropolitan civil class that transforms into a revolution, during which the level of aggressiveness of the empire rapidly decreases.

If the revolution concludes with a victory of the metropolitan civil class, the new authorities established in the course of the revolution will behave just as the old ones and will increase their power control. As a result, they will be faced with an immediate resistance of their own citizens. The way of avoiding of revolution is to enter the first range of aggression. When the possibilities of conquer end, imperial rulers increase power in their country at the cost of own citizens what leads to another revolution of the first kind. Providing it is victorious, the entire cycle of evolution repeats from the beginning. Finally, one of the subsequent civil revolutions is crushed and metropolitan citizens became enslaved. A crushed revolution is followed by an immediate decrease of aggressiveness of the empire. As a result, rulers can increase their internal sphere of regulation. However, in the phase of enslavement, political overcompetitiveness causes the imperial society to enter the second range of aggression. In this case, subjugation of foreign citizens brings about weakening or postponement of self-enslavement of power. In this stage of social evolution, the empire transforms from an empire with a benevolent center, characterized by lower subjugation of metropolitan citizens in comparison to the subjugation of provincial citizens, into an empire with a malicious center, where enslavement of metropolitan citizens is higher in comparison to provincial citizens.

After a certain time, metropolitan civil class exceeds the threshold of civil awakening. In the phase of cyclical declassations the aggressiveness of the empire decreases. The imperial system re-enters the first strip of aggressiveness in the final stadium of the phase of cyclical revolutions of the second kind. The internal increase of political control comes to an end when a strong metropolitan civil society is developed and the provinces experience a civil awakening. In response, the imperial class of rulers engages in a foreign expansion. However, as Nowak aptly argues:

This growth [...] is already pathological. The occasionally rebellious citizens of the metropolis are constantly worsening their role of imperial gendarmes. The authority's 
aggressiveness, with a diminishing potential, only accelerates the destruction of the empire. $^{254}$

\section{On the Class Divisions in the State of Teutonic Knights}

\subsection{Problem}

Let us now apply the model of political society outlined in the previous subchapter for interpretation of the history of a peculiar type of society - the Teutonic State.

The Teutonic State in Prussia (1226-1525) exerted a significant influence on the history of its neighboring societies. Therefore, it is understandable that the history of the Order of the Teutonic Knights has always been one of the most popular subjects of the Polish medieval studies. However, the internal evolution of the Teutonic State substantially differs from the evolution of its neighboring state societies. In the history of the Teutonic society there appeared phenomena of an extraordinary force, in comparison to other societies present in the medieval Europe, and this raises many problems concerning conceptualization of history of the society under investigation. I will discuss only two phenomena. Historiography particularly struggles to explain the phenomenon of the statecontrolled type of economy characteristic for the Order:

Instead of protecting their subjects' trade practices and supporting their merchants in growing wealthier by engaging in overseas trade, the Teutonic Order not only oppressed its own townspeople with the means of a system of protective laws, prohibited export but it also engaged in trade itself. Historiography never attempted to justify the above policy and harshly condemned it at the same time. For that kind of policy turned Order's own subjects into its enemies, hindered any evolution of the oversees trade in the Polish towns and tied the hands of the Order in the attempts to get along with those who traded on the Baltic Sea. ${ }^{255}$

The second example of an incomprehensible phenomenon is the immutable aggressiveness of the Teutonic State. Even the most prominent historians tried to account for it by traditionally evoking the German spirit of eternal desire for conquer:

The Order laying the well-planned foundations of their self-dependent state in Prussia joined Germany in their policy of Drang nach Osten, and particularly the German

254 Nowak, Power and Civil Society, p. 136.

255 Leon Koczy, Polityka bałtycka Zakonu Krzyżackiego (Toruń: Wyd. Instytutu Bałtyckiego, 1936), p. 50. 
expansion that moved from the Polish-German coastal territories, Lübeck and other nearby towns, and the towns on the rivers Elbe and Saale, along the Baltic coast toward the mouths of the Vistula, Neman, and Dvina. ${ }^{256}$

The Teutonic State was created by Germans who exploited the sympathetic attitude of the Christian world to their own benefit and exploited its services to support Drang nach Osten. ${ }^{257}$

The difficulties faced by historians, who attempt to explain the two abovementioned trends in the history of the Teutonic Order, may result from the fact that the social structure of the Teutonic State was different from the social structures of their neighboring countries. According to the authors of the most recent monograph on the history of the Teutonic State, "[t]he legal system in the Teutonic Prussia varied (...) from the model of estate monarchy which was prevalent at that time in the neighboring countries and which ensured a real influence to the privileged classes." 258 Thus, the aim of the society of the Order was to reach a structure of a state country:

It was characteristic of the Teutonic State toward its dissolution and during the first half of the 15th century that the opposition of its subjects against the authorities (...) was growing: knighthood and townspeople primarily aimed at transforming the State into a state country. ${ }^{259}$

Therefore, provided that the social structure of the Teutonic State varied from a typical social estate structure and that only the opposition of its subjects could bring about a social transformation, one ponders what type of society was the Teutonic Order in Prussia and what were the underlying principles of its evolution?

\subsection{The Social Structure of the Teutonic State}

In order to provide answers to the above-posed questions, one must investigate what type of social means the ruling class of the Teutonic society controlled. The ruling class comprised around a thousand knights-monks who ruled a society of more than half a million subjects. The Teutonic Knights were in control of the

256 Stanisław Zajączkowski, Podbój Prus i ich kolonizacja przez Krzyżaków (Toruń: Wydawnictwo Instytutu Bałtyckiego, 1935), p. 8.

257 Henryk Łowmiański, Prusy - Litwa - Krzyżacy (Warszawa: PWN, 1989), p. 164.

258 Marian Biskup and Gerard Labuda, Dzieje Zakonu Krzyżackiego w Prusach: gospodarka, społeczeństwo, państwo, ideologia (Gdańsk: Wyd. Morskie, 1986), p. 285.

259 Biskup, Labuda, Dzieje Zakonu Krzyżackiego, p. 503. 
means of coercion, since "they organized the armed forces of the State, initially by enlisting their own subjects and not by employing mercenary troops." 260

Friars were organized in convents belonging to a single commandry (Komturié) - a basic administrative unit of the State. There were a dozen or so friars in a convent. A Komtur, or a Commander-in-Chief controlled a convent and a commandry. Komturs wielded power over the military forces of a district and thus assumed administrative, judicial and fiscal power. Almost every friar held a separate administrative position. ${ }^{261}$ Since the knights-monks controlled the means of coercion, they constituted a political class of rulers.

Land was the principal mean of production in the Middle Ages. The class of Teutonic rulers owned the majority of land:

The Teutonic Order had a major share of land property in Prussia. The Order was simultaneously the sovereign of the State and the greatest feudal lord, and this land was visibly compact. There is no data available concerning the number and size of the landed estate of the Order, but one may assume that in the territory of the colonized proper Prussia, it would own around two thirds of the cultivation land. In Gdansk Pomerania were the Order conquered and obtained by means of purchase or by expropriation of knights an area previously controlled by Pomeranian dukes, it possessed up to $50 \%$ of cultivation land [...]. The order owned relatively the smallest share, of around $40 \%$ in the district of Chelmno, since that land remained in possession of knights and bishops. One should add that the Order also owned the majority of extensive forests and borderland deserts in proper Prussia, which increased the range of its territorial property. ${ }^{262}$

The Catholic Church was the second biggest landowner in Prussia owning a third of land. It was organized into four bishoprics: Warmia, Pomesania, Sambia, and Chelmno. The Catholic bishoprics were subjugated to the Teutonic monastic authorities. Hence, the economic control of the Catholic Church was purely nominal:

The administrators of the land estates, called "voyts," were appointed by bishops or the Chapter, but even in this case the Teutonic authorities enforced the principle that voyts were recruited among the members of the Order, thus making them dependent from the Grand Master of the Order; even the Bishops of Warmia (but not the Chapter) accepted the principle. Following from this, through its administrative apparatus, the Order exerted a decisive influence over the internal affairs of the land estates belonging to bishops, thus indirectly included into the administrative system of the Teutonic state. ${ }^{263}$

260 Biskup, Labuda, Dzieje Zakonu Krzyżackiego, p. 279.

261 Biskup, Labuda, Dzieje Zakonu Krzyżackiego, p. 203.

262 Biskup, Labuda, Dzieje Zakonu Krzyżackiego, pp. 300-301.

263 Biskup, Labuda, Dzieje Zakonu Krzyżackiego, p. 278. 
In addition to the land property of the Order and, mostly nominal, property of the Catholic Church, on the territory of the Teutonic State there were also estates owned by knights (a single class of owners) limited geographically to the district of Chelmno and Gdansk Pomerania. However, the double-class of rulers/owners gradually reduced the rights of property of the knights. For example, all legal transactions concerning this social group had to be approved by the Teutonic authorities. The Order also reserved for itself the right to build mills and town settlements on properties belonging to knights. ${ }^{264}$

The Teutonic Order exerted a decisive influence on the functioning of the new domains of manufacture - the town economy. It founded 93 towns. By creating "new" town settlements, the Order balanced the impact of old pre-Teutonic town centers. The new towns, despite the fact that they were given less rights, constituted a substantial economic competition to the old towns founded before the appearance of the Teutonic monks. The dominance of Teutonic authorities was clearly visible in all town centers:

[T]he influence was exerted by Teutonic officials, particularly by Komturs [...] who interfered into the matters concerning the election of town authorities, town legislation and, partially, the judiciary, craft, trade, and the issues of the policy of the Hanseatic League. As a result, the internal autonomy of towns was vastly restricted, including the large ones, and simultaneously allowed for abuse of power on the part of the Teutonic authorities. ${ }^{265}$

The interference into internal town affairs went down as deep as the craft guilds, since "the Order not only had the statues of guilds presented for acceptance, but it also interfered with the internal system of relations within guilds and dictated prices for craft goods." 266

Teutonic monks were directly involved with banking, trading and crafting activities. For this reason:

[d] uring the first half of the 14th century at the latest, a trading apparatus was developed designed for supervision over a vast trading area which included Prussia, northern Poland, Lithuania and Western-European counties, particularly Flanders. The apparatus was headed by Teutonic officials in Marienburg and Königsberg, called the Grand Stewards). The Grand Steward of Marienburg was predominantly responsible for grain trade [...]. The Grand Stewards controlled the apparatus of buying and selling with the help of lower trade clerks, Commission Merchant (Lieger) and Trade Servants (Dienen)

264 Biskup, Labuda, Dzieje Zakonu Krzyżackiego, p. 209.

265 Biskup, Labuda, Dzieje Zakonu Krzyżackiego, p. 322.

266 Biskup, Labuda, Dzieje Zakonu Krzyżackiego, p. 328. 
[...]. Every Teutonic castle had its own officials - stewards dealing with trade at a local level. ${ }^{267}$

The Order traded predominantly with amber, wood-ash and timber. ${ }^{268}$ It was also buying Flemish woolen cloth, which they distributed within the country. The Order basically monopolized export of agricultural goods, by making it obligatory for grain producers to sell produce, by issuing licenses to trade it and by blocking the Baltic Sea to ships. The Teutonic institution also organized its own craft production that provided a substantial threat to the evolution of town manufacturing business:

[I]nstalment of Teutonic officials, known as botchers, in the settlements at the foot of the castles constituted a substantial competition to the guild craftsmen. The increase of fees in the Order-monopolized industrial establishments, particularly in mills and fulleries hit the two trades most popular in towns, namely brewing and cloth making; similarly, the production of the Order-owned breweries supplying village inns was economically disastrous for small towns in particular, as beer-making was the only source of their profit. ${ }^{269}$

The Teutonic Order had substantial financial resources and was a financier of the State, loaning money to its subjects. In this respect, according to Karol Górski, the Order "was an exceptional phenomenon among Medieval countries, as everywhere else sovereigns would borrow money from its subjects, and [Teutonic Knights] were lending money to them." 270

The direct involvement of the Order in economic activities was exceptional for Medieval Europe, since: "[a]t that time, never did any European country engage itself in an economic activity of its own, but limited to possession of land estates and mines, but even these properties and often salt-mines were being leased."271

Thus, one can interpret the Teutonic Knights as a double-class of rulers/ owners. Moreover, they managed to completely subordinate the clergy of the Catholic Church:

267 Biskup, Labuda, Dzieje Zakonu Krzyżackiego, p. 330-31.

268 For a genesis of Teutonic trade, see: Udo Arnold, Zakon Krzyżacki. Z Ziemi Świętej nad Bałtyk (Toruń: Wyd. UMK, 1996), pp. 50-60.

269 Marian Biskup, Zjednoczenie Pomorza Wschodniego z Polska w połowie XV wieku (Warszawa: PWN, 1959), pp. 28-29.

270 Karol Górski, Państwo Krzyżackie w Prusach (Gdańsk: Wydawnictwo Instytutu Bałtyckiego, 1946), p. 123

271 Górski, Państwo Krzyżackie, p. 120. 
[T] he Order authorities, aware of the significance and role of the hierarchy of the Catholic Church, already in the second half of the 13th century conducted an action designed at establishing control over individual Prussian bishoprics by means of incorporating their Chapters into the Order. [...] Teutonic Knights exerted influence in the incorporated Chapters particularly concerning the election of bishops, usually suggesting the appointment of their own protégés (typically, the Grand Masters' chaplains); additionally, they influenced the election of new members of the Chapter who had to become monks. The Grand Masters reserved from themselves, as the Order's superiors, the right to inspect the Chapters, considering their members and the bishops to be their subjects. ${ }^{272}$

This resulted in that:

the Prussian Church hierarchy became entirely subordinated to the Teutonic authorities and played a subservient role. From amongst the Prussian clergy were recruited many of the Order's members, i.e. the Grand Masters' chaplains and convent's scribes, prosecutors, who supported the strengthening of power. ${ }^{273}$

The Order exerted decisive influence on the development of other congregations of monks. Its permission or objection was decisive for the establishment of new monasteries, and donations and inheritance could not be made to other orders without the permission of the Teutonic Order. Within the boundaries of the Teutonic State there were only the monastic orders that have appeared on the Prussian territory before the arrival of Teutonic Knights - Franciscans, Dominicans, and monk congregations in Gdansk Pomerania that had been incorporated into the Teutonic State in 1309. The subordination of the Catholic Church to the Teutonic authorities prevented a separation of politically and economically independent bishoprics, as it happened in the German Reich and the neighboring Livonia. To the outside world and to its own subjects, the authorities of the Teutonic State and bishops took the shape of a unified organism. By subordinating the Catholic Church, the Teutonic authorities became, in fact, in control of the means of spiritual production.

Thus, the knights-monks had the means of coercion at their disposal; they owned the vast majority of land and the most essential means of production in towns, and they were in control of the means of spiritual production. As a result, they were a class of triple-rulers. However, in a Teutonic society, except for the triple-ruling class, there existed both layers of a single-class of owners: knighthood and townspeople. And in some periods of history of the Teutonic State, bishopric in Warmia enjoyed a relatively large independence from the Teutonic

272 Biskup, Labuda, Dzieje Zakonu Krzyżackiego, p. 426.

273 Biskup, Labuda, Dzieje Zakonu Krzyżackiego, p. 427. 
system. For this reason, the Teutonic society cannot be considered an ideal socialist society, but a quasi-socialist society. ${ }^{274}$ Nonetheless, it is worth investigating if the internal evolution of the society under study is in line, at least roughly, with the mechanism of evolution of a political variant of a socialist society.

\subsection{Evolution of a Teutonic Society}

Let us now investigate whether the history of the Teutonic society includes developmental phases characteristic for the evolution typical for a political society: the phase of growing civil alienation - the phase of the revolution of the first kind - the phase of enslavement - the phase of cyclical declassations, and the phase of cyclical revolutions.

After they had come to terms with Prince Konrad of Mazovia, the Teutonic Knights settled in 1228 in the District of Chelmno. The day before the settlement, there were around 170,000 inhabitants in the Prussian territory. ${ }^{275}$ Native Prussians were organized into non-state tribes-families: "The free native Prussians formed the core of the Prussian population; at the two extremities of the social ladder there were: a small group of wealthy citizens (nobles, warriors) on one side, and groups of slaves on the other."276

The Teutonic rule substantially reduced the autonomy of the Prussian people in terms of politics, they became feudal subjects, and in the spiritual sphere, they were subjected to obligatory Christianization.

In 1231-1242, the Teutonic Knights subjugated Prussian tribes living on the right bank of the lower reaches of the Vistula river in the territories of Pomesania, Pogesania, and Warmia. The Teutonic rule brought about a drastic reduction of the autonomy of the local people. A Prussian insurrection broke in 1242 and lasted for eight years. It spread over the entire Prussian territory occupied by the Knights. The Teutonic Order crushed the insurrection and, as a result, conquered all of the remaining Prussian territories. In 1250-1260, the Teutonic Knights subordinated Natangia, Bartia, and Sambia. Once more, the reduction of freedom of the Prussian people brought about an outbreak of an insurrection

274 This is a modification of my previous standpoint expressed in: Krzysztof Brzechczyn, "The State of the Teutonic Order as Socialist Society," in: Social System, Rationality and Revolution, eds. Leszek Nowak and Marcin Paprzycki (Amsterdam - Atlanta, GA: Rodopi, 1993), pp. 397-417.

275 Lowmiański. Prusy - Litwa - Krzyżacy, p. 59.

276 Biskup, Labuda, Dzieje Zakonu Krzyżackiego, p. 76. 
(1260). The insurrection lasted for fourteen years and it spread over all territories occupied by Knights, with the exception of initially conquered Pomesania. In the initial stage of the insurrection, native Prussians managed to gain control over almost all major Teutonic strongholds and towns. Only with the external help of, predominantly, the German and Czech knights, the scale of victory tipped to the favor of the Order. ${ }^{277}$ After fourteen years of struggle, the Knights implemented mass terror and crushed the Prussian insurrection. Henryk Łowmiański describes the Teutonic/Prussian battle in the following way:

[the Teutonic Knights] had systematically destroyed tribal districts one by one, razing their settlements to the ground, taking women and children prisoner, and murdering all the men who were attempting to defend the country. Teutonic troops marched through the land leaving only burned-out ruins and empty fields. ${ }^{278}$

The total loss of Prussian life equaled from $20 \%$ to $50 \%$, depending on the district, with respect to situation before the uprising. ${ }^{279}$ The South-East regions of Prussia became almost completely depopulated. The Teutonic conquest of Prussia concluded in 1283 with the subordination of the tribes of Nadrowia, Skalowia, and Sudowia to Knights. Thus, one can interpret the evolution of the Teutonic society in the years 1228-1283 in terms of an increase of civil alienation and a revolution of the first kind.

After the defeat of the Prussian uprisings, the influence of the subjects on the (triple-) authorities of the Teutonic Order was minimal. The Knights intervened in all spheres of public life, since they enlarged their administrative apparatus dealing with trade, banking and even manufacturing of certain basic craft goods. By competing against its own townspeople in grain trade, the Order succeeded to completely monopolize the field in the 14th century. In order to limit the social impact of large town centers that pre-dated the arrival of the Knights or were established under their rule, the Teutonic monks surrounded them with "new towns" that had, as a rule, a smaller autonomy. ${ }^{280}$ As a rule, the new towns were not given the right to issue internal regulations (Germ. Willkür) controlling the

277 For example, the campaign of the Teutonic Knights against the Prussians was supported in 1265 by Albrecht, Duke of Brunswick and Albrecht, Landgrave of Thuringia, in 1266 by Otto III, Margrave of Brandenburg, in the years 1267-1268 by Ottokar II, the king of Czech and in 1272 by Theodoric, Margrave of Meisen.

278 Łowmiański, Prusy - Litwa - Krzyżacy, p. 140.

279 Biskup, Labuda, Dzieje Zakonu Krzyżackiego, p. 190.

280 Edmund Cieślak, Walki ustrojowe w Gdańsku i Toruniu oraz w niektórych miastach hanzeatyckich w XVw. (Gdańsk: Gdańskie Towarzystwo Naukowe, 1960), pp. 30-33. 
life of towns, the right to issue own coins and autonomous judiciary. For instance, in the 14th century, there were as many as four town settlements in Gdansk alone: Main Town, Old Town, New Town, and Osiek. Next to Königsberg, New Town grew in 1300 and soon afterwards Knipawa was founded. In 1347, a New Town appeared also in Elbing close to the old part of the town. At the beginning of the 15th century, the Order usurped the right to the municipal trade taxes paid voluntarily by towns belonging to the Hanseatic League - this was a sign of a growing interference of the Order into the functioning towns.

In the case of knights inhabiting the District of Chelmno granted to the Teutonic Order and Gdansk Pomerania conquered in 1308, the intensification of state control was reflected in limiting the process of granting land estates in conformance of the local Chelmno Law. The Chelmno Law allowed the daughters of knights to inherit property and made the military service compulsory only within the borders of the country. On the contrary, the Polish and Magdeburg law limited the group of beneficiaries to males. In the absence of male heirs, the possessions became the property of the Order. Moreover, the Polish and Magdeburg law made it obligatory for the knights to perform territorially and temporarily unlimited military service and requested a series of other, minor contributions. Thus, the Polish and Magdeburg law undoubtedly restricted the autonomy of knighthood more than the Chelmno law. After 1340, the Order started to limit the number of locational charters granted in conformance with the Chelmno law, by using several variants of the law. According to cautious opinions of historians, "probably the principal criterion" of the choice of a variant of the Chelmno law "was the level of readiness [of the knights] to cooperate with the Order and its officials."281 And after 1410 the Order stopped to grant locational charters in conformance with the Chelmno law altogether. Furthermore, making use of the rights of the Polish law, in the years 1308-1454, the Order became the owner of ca. 100 villages, which had been previously owned by local knights. ${ }^{282}$ This period of reinforcement of the ruling of the Teutonic Order may be interpreted in terms of the phase of political enslavement.

At the end of the 14th century, the most powerful layer of subjects of the Teutonic State, the knighthood of the Chelmno District, set up the Lizard Union

281 Maksymilian Grzegorz, Struktura administracyjna i własnościowa Pomorza Gdańskiego pod rządami Zakonu Krzyżackiego w latach 1309-1454 (WarszawaPoznań-Toruń: PWN, 1987), p. 151.

282 Grzegorz, Struktura administracyjna, p. 147. 
(Eidechsengesellschaft). ${ }^{283}$ This action may be interpreted as a manifestation of formation of independent social ties that gradually covered more and more social circles. The Prussian Union established in 1440 grouped the representatives of knights, townspeople and wealthy peasants. According to Marian Biskup and Gerard Labuda: "given the specific conditions of the monastic state, the Prussian Union was a representation and an embodiment of the opposition aims of the majority of subjects that coordinated their further strife." 284

An attempt at repressing the rebelling subjects brought about an outbreak of an anti-Teutonic uprising. The uprising started in 1454 and spread over the southwest provinces of the State. Insurgents managed to gain control over the Teutonic castles in the towns of Pomerania, even before they received help from the Polish troops. The support of Poland transformed the uprising of subjects into a long-lasting Polish-Teutonic conflict concluded in 1466 with the acquisition of Gdansk Pomerania and Warmia to Poland, and subordination of the Teutonic society to Poland.

The weakening of the Teutonic rule forced the authorities of the Order to grant concessions. The rights of the Order were predominantly reduced in the economic sphere. This process was manifested in a resignation from the previously favored. the Magdeburg law and in granting a mass number of locational acts concerning the land formally owned by the Order. The new class of nobility, established as a result, became an equal partner to the Teutonic authorities. Additionally, the internal monastic hierarchy underwent a transformation concerning control over land. Monks of lower rank considered their spiritual function as a mere source of additional income and decided to take Orderowned land on security or lease. This way, these monks became legal landowners (they had already been the real owners due to their affiliation to the triple-class of rulers). At the same time, the higher layers of the Order's hierarchy close to the Grand Master were gathering a purely political power in their hands. The above were the social implications of the administrative-military reform of 1506 that deprived the former Komturs of their power in this field, and of the centralization of judiciary. The Grand Master and his vicinity were gradually transforming into a center of purely political power, and the monks of lower ranks - into possessors of purely economic power.

283 Marian Bartkowiak, Towarzystwo Jaszczurcze w latach 1397-1437 (Toruń: Towarzystwo Naukowe, 1948), pp. 5-6.

284 Biskup, Labuda, Dzieje Zakonu Krzyżackiego, pp. 398-399, my emphasis. 
The factor accelerating the disruption of socialism in Prussia was the lost war against Poland (1519-1521) that ended with a four-year truce. This war intensified social transformations occurring within the structures of power and ownership, which caused the Teutonic society to resemble more and more a typical class society. Most importantly, the intensification concerned the processes of granting monastic land to individual owners in order to compensate for war damages. Otherwise, the noble class would have supported a fusion with Poland. The Cracow treaty from 1525 conclusively confirmed the secularization of Prussia, hence, the dissolution of the Order of Brothers of the German House of Saint Mary in Jerusalem. It appears that political authorities perceived the institutional structure of the monastic order to be dysfunctional for a class society. Former monks gave up their monopoly over control of the means of spiritual production and created a single-class of owners or rulers. In consequence, a typical class society was formed, with separate classes of rulers, owners and priests (who, as a result of the secularization, changed their ideological doctrine from Catholic to Lutheran). The final episode of the history of the Teutonic Order corresponds with the phase of regular revolutions of the second kind of the model of a political society, where political control is reduced to a strip of class peace.

Considering the strong simplifying assumptions of the basic model of a political society (disregarding economic and cultural influences, neighboring societies, political institutions and political awareness), it provides a satisfactory approximation to the history of the Teutonic society, since it includes the phases: of growing civil alienation, revolution of the first kind, enslavement, and cyclical declassations. However, there are discrepancies between the historical evolution of the Teutonic society and the idealized course of an evolution of a socialist society. I shall name only the most significant differences. Most importantly, a crushed revolution of the first kind is supposed to bring about social enslavement. In contrast, there was a social group of "Prussian free" peasants within a Teutonic society until the end of the 15th century. Furthermore, the basic model of a socialist society assumes there should appear a sub-phase of self-enslavement of power - a phenomenon absent from the history of the Teutonic society. It is noteworthy that the basic model assumes there should appear a series of lost revolutions in the phase of cyclical declassations. Yet, the period in the history of a Teutonic society corresponding with this phase of evolution of political society is definitely shorter. As a matter of fact, one revolution was sufficient to reduce the scope of state control to the area of class peace.

The above-described deviations from the basic model might probably be accounted to interference of factors that were disregarded within the initial model. The inclusion of the economic aspect of social processes might explain 
the presence of the social category of "Prussian freeman." This group originated from the treaty of Dzierzgon from 1249 that concluded the Prussian insurrection. The treaty granted Prussians personal freedom and the right to own and inherit land in return for military service and acceptance of the political power of the Order. ${ }^{285}$ To put it in more general terms, when faced with the revolution of the Prussian natives, Knights who held political and economic power reduced their control over the economic sphere, in order to preserve political control. In consequence, they disrupted the solidarity of the Prussian people and curtailed the insurrection. Historians have expressed accurate intuitions in this respect:

The Teutonic Knights attempted to disrupt the solidarity of the insurgents by widely allocating land among the class of wealthy Prussians whom - by means of that - they kept loyal or forced to side with the Order. This activity, undertaken particularly among the noblemen of Sambia, soon resulted in the Order re-conquering the district. ${ }^{286}$

On the other hand, by including the influence of internal social relations, one would allow an explanation of the absence of power self-enslavement in the history of the Teutonic society. Self-enslavement of power is a stage in the evolution of a political society, in which, having gained control over all spheres of public life, a ruler moves on to the spheres of influence of other rulers. Under the conditions of social isolation the only solution to the problem of competition between rulers is regular elimination of the surplus of the candidates to power. However, if the simplifying assumption concerning social isolation is reduced, competitiveness for power could be weakened with external expansiveness. Conquest of foreign societies is a more effective method of finding additional spheres of state control than competition between rulers. In this case, political rivalry does not have to take place at the expense of social territories controlled by other rulers, but at the expense of the, until then, autonomous spheres of public life in the neighboring societies. Teutonic aggressiveness, by adding new unexpected spheres of state control, removes the threat of power self-enslavement and weakens the danger of total enslavement of the society.

Furthermore, the impact of unsuccessful aggressions would allow for a better understanding of the final period in the history of Teutonic society. The lost wars against Poland - the state with a substantially higher level of social

285 Cf. The interpretation of the Dzierzgon treaty in: Karol Górski, Zakon Krzyżacki a powstanie państwa pruskiego (Wrocław: Ossolineum, 1977), p. 40.

286 Zajączkowski, Podbój Prus, p. 26. 
autonomy - weakened the rule of the Knights. ${ }^{287}$ The wars also reinforced the process of formation of state-independent social ties, since the representatives of the Teutonic society frequently served as guarantors of the agreements signed between Poland and the Order. The Polish intervention of 1454 contributed to the success of the anti-Teutonic insurrection and the war of 1519-1521 concluded the period of triple-power system in Prussia.

\subsection{Conclusions}

I will now use the above-presented model of explication of the history of the Teutonic society to interpret the phenomena in the history of the Teutonic Order that, as was presented in the sub-chapter 2.1 ("Problem"), are difficult to account for in terms of traditionally applied theoretical assumptions. The first phenomenon is the unique for medieval Europe state-controlled type of economy, which substantially decreased the income of townspeople. This phenomenon is, however, perfectly understandable in terms of the offered model of explanation. For a triple-power, economy, correspondingly to other spheres of public life, primarily serves maximization of political control. Consequently, all matters pertaining to ownership, organization of production and trade come to be subordinated to the criterion of maximization of power. However, if the aim to increase profit to maximum is not the primary criterion determining the type of economy but becomes a merely secondary criterion, then the economy becomes less effective and profitability of the economic activities decreases.

The second problem is the phenomenon of eternal Teutonic aggressiveness, which has been traditionally explained in terms of Drang nach Osten. This concept is associated with the idealistic notion of the Spirit of the Epoch fatalistically predetermining the history of humanity. With respect to Germans, it was supposed to account for their expansiveness of this nation by invoking factors inherent in its national character. The concept of Drang nach Osten treated disparate phenomena, such as the campaign of Charlemagne, the wars of Otto I, Otto II and Otto III, German settlements, Teutonic aggressiveness and even the participation of the absolutist Prussia in the Partitions of Poland, as a unified whole. $^{288}$

287 Hans Rosenberg, “The Rise of the Junkers in Brandenburg-Prussia, 1410-1653," part I, American Historical Review, No. 1, Vol. 49 (1943), pp. 6-7.

288 Benedykt Zientara, "Drang nach Osten (Parcie na Wschód)," Mówią Wieki, No. 4 (1984), pp. 1-2. 
The model of explanation proposed here does not perceive the aggressiveness of the Knights as a part of the manifestation of the Spirit of the Epoch, but as a result of objective evolution of class (political) relations within the society of the Teutonic state.

In the evolution of a typical socialist society there are two waves of aggressiveness. ${ }^{289}$ The Teutonic wars of the 13th century against Swietopelk I, Duke of Pomerania, may be interpreted in terms of the first wave of aggressiveness which weakens the danger of an outburst of civil revolution. Whereas the Teutonic aggressiveness after the crushing of the Prussian insurrections, including the conquers of Gdansk Pomerania and Kuyavia, campaigns against Lithuania and the occupation of Samogitia (Žemaitija), the conquest of Swedish Gotland, may be interpreted in terms of the second wave of aggressiveness which hampered the danger of self-enslavement of political authorities.

\section{Alternative History and the Rise of Socialism in Russia}

For the purpose of this book, I have adopted the assumptions of non-Marxian historical materialism. However, I do not accept this theory unconditionally because certain problems demand a clarification. One of them is the issue of mono-linear historical evolution. I will now discuss the problem with the case of Russia. Russian historiography offers two basic concepts of the origins of Russian socialism. According to the first interpretation, reconstructed by Mikhail Heller and Aleksander Nekrich:

Many Western historians [...] find the sources of the 1917 revolution in the internecine warfare of the Kievan princes, the Tatar yoke, the atrocities of Ivan the Terrible, [...] Reaching back into the distant past [...] Western historians draw a direct line from Ivan Vasilyevich (Ivan the Terrible) to Joseph Vissarionowich (Stalin) or from Malyuta Skuratov, head of the Ivan the Terrible's bodyguard and secret police force to Yuri Andropov, the longtime head of the KGB who recently headed the Soviet state, thus demonstrating that from the time of Scythians Russia was inexorably heading toward the October revolution and Soviet power. ${ }^{290}$

The second interpretation, favored e.g. by the above-quoted authors aims to prove that the transformation from the pre-October Russia to the Soviet Union was:

289 On the weaker forms of expansionism, see: Brzechczyn, "Unsuccessful Conquest," pp. 445-456).

290 Mikhail Heller and Aleksander Nekrich, Utopia in Power. The History of the Soviet Union from 1917 to the Present (New York: Summit Books, 1986), p. 10. 
The history of the Soviet Union is the history of the transformation of Russia - a country no better no worse than any other, one with its own peculiarities to be sure but a country comparable in all respects to the other countries of Europe - into a phenomenon such as humanity has never known. ${ }^{291}$

Leszek Nowak expressed his standpoint in line with the first of the abovepresented interpretations. ${ }^{292}$ In terms of $\mathrm{n}-\mathrm{Mhm}$, the fundamental distinctiveness between various European societies is the simultaneous division between and balance of three social classes of rulers, owners and priests, which occupied the most significant positions in politics, economy and economics. This balance had been substantially disturbed within the Russian society when, at some point in history, political power merged into one with control over the means of production. As a result, a double class of rulers-owners was created. The competition between landed gentry - a social class that cumulated ownership with power, and boyars - a class of individual owners, exhausted the social aspect of the modern history of Russia. This totalitarian anomaly caused state feudalism, without the stage of free competition to transform into state capitalism, and then into socialism, where political power took control over the means of production and propaganda.

Thus, it is noteworthy to repeat the question of the mechanism of development of Russian socialism. Did this system emerge as a result of blind necessities - as suggested by the first mono-linear interpretation, or as a result of blind faith, as suggested by the second, multi-linear concept of the Russian history? Did history unfold as it did because it was bound to, or was it just a combination of fatal coincidences?

I would argue that neither of the two counter interpretations is entirely true. However, there is another possible answer assuming that Russia indeed had a totalitarian anomaly, but that it did not evolve in a straight line connecting Genghis Khan and Joseph Stalin. There were moments in the history of the investigated country when various social powers were approximately equally capable of enforcing their class interests. Then, coincidence would have frequently decided which tendency had dominated. In the interest of landed nobility or landed gentry (the double-class of rulers/owners appears in source materials under a number of names) was to combine ruling with land ownership. On the other hand, division of land and making land ownership independent

291 Heller, Nekrich, Utopia in Power, p. 11.

292 Nowak, Droga do socjalizmu, an abbreviated version is available in English in: Nowak, Property and Power, pp. 239-378. 
from power manifested the social interest of boyars. Providing the influence of both classes and their ability to implement their social interests was equal, the additional circumstances decided which social tendency prevailed and which class interest was implemented. To put it differently, there were turning points in the Russian past when history could have unfolded either way. Let us now attempt to enrich the image of the evolution of the Russian society described by Nowak with the not-implemented alternatives of development. One of the turning points of the Russian history was the beginning of the 17th century. After the unsuccessful military campaign of False Dmitry I supported by Polish magnates, a rebellion led by Ivan Bolotnikov broke out. It spread over all layers of the Russian society and disrupted the foundation of a system of pomeste. The year 1608 saw another interference of the Polish magnates who found the second Dmitry. The following year, the Polish army besieged the city of Smolensk initiating an open military intervention. In February 1610, Russian boyars approached Smolensk and addressed the Polish king Sigismund III Vasa with a proposition to put his son on the Muscovite throne. Sigismund III agreed and soon a treaty followed. According to the treaty, prince Vladislav IV Vasa would convert to Orthodox Christianity and the country was to be co-ruled by the Boyar Duma. The signed Smolensk treaty was soon reinforced by a military victory of hetman Stanislaw Żółkiewski in the battle of Klushino (4 July 1610). As a result of a coup in Moscow, the then tsar Vasili IV of Russia was deposed and forced to become a monk. In August 1610, another treaty was made between the representative of Vladislav IV, Żółkiewski, and the Russian boyars. The treaty prepared by Żółkiewski:

obliged Vladislav IV, when he becomes tsar, to rigorously follow the existing supremacy of Orthodox Christianity, to maintain the existing laws and traditions, unless the Boyar Duma and the representatives of the "entire land" decide otherwise, and that he will not punish anyone with death and confiscation of possessions. ${ }^{293}$

Ludwik Bazylow adds "[a]fter the treaty was signed, Moscow swore by the faithfulness of Vladislav IV, and the same was done in many other towns. It appeared that the end of the Time of Troubles was coming." 294

The perspective of putting Vladislav IV on the Kremlin throne was very real in light of opinions expressed by historians specializing in the history of Russia and the epoch. Why it did not happen? Historians explicating this episode in the history of Polish-Russian relations refer to the personal ambitions of Sigismund

293 Ludwik Bazylow, Historia Rosji (Wrocław: Ossolineum, 1985), pp. 138-139.

294 Bazylow, Historia Rosji, p. 139. 
III Vasa who succumbed to the whispers of the Society of Jesus and prevented his son to convert to Orthodoxy, because he wanted to sit on the Muscovite throne himself. As a result, a Polish king would become a ruler of a gigantic PolishLithuanian-Muscovite country with introduced compulsory Catholicism. ${ }^{295}$ As a result:

[t]he stance of Sigismund III brought about a mere ceasefire, particularity when also the Swedes announced their candidate to the throne and occupied Novgorod. In this desperate situation, the Russian masses voiced their demands. A mass fight with the invaders begun. Thousands of people formed a mass mobilization and headed toward Moscow causing an insurrection to outburst and a siege of Poles in Kremlin. ${ }^{296}$

Following from this, the unsuccessful attempt of Vladislav IV to assume the Russian throne was a consequence of factors identified in terms of n-Mhm as accidental: personal ambitions of Sigismund III, his attachment to Catholicism, his aversion toward Orthodoxy, him succumbing to the whispers of the Society of Jesus, etc.

What if Vladislav IV became tsar?

Vladislav IV would have to found his rule on the social group that led him to power - the boyars. Alliance with landed nobility that supported the then tsar Vasili IV of Russia was impossible. The rule of Vladislav IV would have been a consequence of the dominance of boyars over landed nobility, a social class that grew in strength as a result of the accumulation of power and ownership. Moreover, in this theoretically possible social coalition of tsar Vladislav IV and the boyars, Vladislav IV, a foreigner unfamiliar with the local relations and agreements, would have been a significantly weaker link. Weak authorities have only one way of gaining social support at disposal -concessions. Concessions granted by Vladislav IV would have taken the same form, as in the entire Europe - the act of granting land - since the Russian state was the largest landowner, but on terms established by the stronger part of the coalition.

At the turn of the 16th and the 17th centuries, there appeared at least theoretical perspectives for weakening or even annulling the totalitarian anomaly present within the Russian social structure. Russia could have become a regular feudal state with political power subjugated to large land ownership.

295 Cf. Bazylow, Historia Rosji, p. 139; Jerzy Gierowski, Historia Polski 1505-1764 (Warszawa: PWN, 1983), p. 156; Jerzy Ochmański, Dzieje Rosji do roku 1861 (Warszawa: PWN, 1983), p. 131; Zbigniew Wójcik, Historia powszechna XVI-XVII w. (Warszawa: PWN, 1979), pp. 316-317.

296 Gierowski, Historia Polski, p. 156. 
The second turning point in the Russian history was the period between February and October 1917. When German intelligence smuggled Lenin into Russia in April 1917, he barely managed to disturb the plans of Kamenev and Stalin that included "to unite with the Mensheviks and collaborate to a certain degree with the Provisional Government." 297

Furthermore, by threatening to resign from the Central Committee, Lenin basically forced the leadership of the Bolshevik Party to appoint a date for a military coup.

Let us now pose the same question as before: what if Lenin did not succeed in stopping the Party from forming the coalition with the Mensheviks and in persuading the Party that a military coup is necessary to gain power, or if the coup was unsuccessful? Nowak provides an explicit answer:

The October Revolution lead from a totalitarian society to a totalitarian society - it merely brought about a substitution of the people in power, not a transformation of a social structure. [... .] New rulers-owners substituted for previous rulers-owners and the society evolved in the same direction, only faster.

Moreover, the change of personnel in the Russian social structure was possible because the politics of previous rulers-owners brought about an opposition of the Russian people - an opposition skillfully directed and controlled by the new state structure that grew in power. ${ }^{298}$

I shall now attempt to demonstrate that the substitution of the political force of Liberals, Mensheviks and the Social-Revolutionary Party into Bolshevik one cannot be simply explained with the terms of substitution of personnel. These differences can be expressed in terms of the conceptual apparatus of n-Mhm. Furthermore, the accumulation of these differences - providing the Russian Provisional Government continued to rule instead of the Bolsheviks, would have brought about social consequences reflected in the social structure of the country.

There were two hierarchies of power in Russia during the revolution: the first based on the former tsarist administration, the second based on a system of Soviets (political and governmental councils). For this reason, cooperation between Bolsheviks and Mensheviks would have brought about an incorporation of Lenin's party into the official power structures. It would have caused the hierarchy of power based on the system of Soviets to weaken, making it capable of stimulating social opposition, yet not of taking over. The official power structures

297 Heller, Nekrich, Utopia in Power, p. 29.

298 Nowak, Droga do socjalizmu, pp. 245-246. 
introduced totalitarianism to public life causing an immediate social resistance and, as a result, the objective result of the above actions was naturally smaller. The situation would have been different in case of the hierarchy originating from civil society. There would have had to pass a certain period of time for a society to realize that the nature of the new system of power is similar to the old one. For this reason, the hierarchy of power based on the system of Soviets was more effective in introducing totalitarianism, since initially it would not have had to face social resistance.

Moreover, the official hierarchy of power comprised a three-party coalition: Constitutional Democratic Party (Kadets), Mensheviks, and SocialistRevolutionary Party. Each of these parties had a more democratic internal structure than the Bolshevik Party. The elections to the Russian Constituent Assembly would have brought about changes causing the official power elites to be elected democratically and to be controlled by civil society. The above does not apply to tsardom or the Bolsheviks. As a result, the democratic channels of control of political power would have had substantially disturbed the accumulation of power and ownership.

Contrary to its political rivals, the Bolshevik Party had a compact and concise organized ideology. Marxism was more than a concept of social organization but also a worldview, or even a religious doctrine. As a result, it exerted greater impact on the then unfolding social processes, in comparison to any standard political ideology. Moreover, its influence accelerated the growth of totalitarianism within the Russian society. Thus, in terms of the philosophy of history, Marxism provided an explanation of the behavior of the Bolsheviks and justified the abolition of private ownership. The existence of owners in a class society is the only real counterweight securing the interest of civil society against the omnipotence of the state. By questioning the significance of private ownership, Marxism objectively supported totalitarian tendencies in Russia.

The list of differences could be extended with indecisiveness of the leaders of the Provisional Government versus Lenin's political abilities, financial support for German intelligence, etc.

The common trait of both hierarchies of power - the official and the unofficial one - was the social situation they were forced to face. The necessary condition for political stability, regardless of the governing hierarchy of power, were the concessions granted to the most powerful social sub-structure in Russia peasantry. Bolsheviks were the first to understand it. They encouraged peasants to occupy land without official authorization, a practice later approved by the Petrograd Soviet of Workers' and Soldiers' Deputies. Providing the Russian Provisional Government had remained in power, it would have had to do the same. The Russian Constituent Assembly was supposed to deal with the issue. 
In terms of $\mathrm{n}-\mathrm{Mhm}$, the enfranchisement of peasants was a creation of a new class of owners. Thus, the enfranchisement of peasants reinforced civil society in Russia and a single-class of owners not associated with power.

Providing the Russian Provisional Government had remained in power, the Russian social structure would have reflected the differences between the Liberal-Menshevik-Social-Revolutionary structure of power and the Bolshevik one. There are two possible variants. In the first, "optimistic" variant, Russia would have remained a quasi-totalitarian country with a class of rulers/owners and independent owners. Compared to the pre-revolutionary period, however, the enfranchisement of peasants would have reinforced the class of owners, and the introduction of parliamentary democracy would have subjected the entire power structure to the control of citizens. Two social tendencies could have manifested in such society: first, for a state-controlled type of economy, in line with the interests of the bureaucratic sector and, second, for liberalization of the economy, in line with the interests of pure bourgeoisie. In the situation of political democracy, one cannot predict which of the two trends would have prevailed. In favorable conditions, the Russian society could have become a standard class society, or a society where the interests of both social classes would have been implemented evenly.

In the "pessimistic" variant, Russia would have remained a quasi-totalitarian country, where a class of triple-rulers was accompanied by independent elites, private ownership and free circulation of information. In terms of philosophy of history, the difference between socialist and quasi-socialist societies is unsubstantial. However, in an ethical or individual perspective, the difference becomes enormous. According to the adopted theory, there are two ways to increase state control to maximum - terror and bureaucracy. Strong authorities employ terror, since it is more effective and brings about more control in a shorter period of time. Weak authorities employ time-consuming bureaucracy. For this reason, one may assume that in a weak-socialist society, the processes of accumulation of power, ownership and authority would have unfolded more moderately and gradually, if brought about by bureaucracy, in comparison to terror. Following from this, provided a similar social system had been created without Lenin or the Bolshevik Party, it would have been less dreadful - without the collectivization of agriculture and causing millions of Ukrainian and Russian peasants to starve to death, without the terror of Cheka and NKVD (abbreviated from: Narodnyy Komissariat Vnutrennikh Del, in English: People's Commissariat for Internal Affairs), without the Gulag and the concentration camps, without the enforcement of atheism and the stupefying propaganda. I would argue that the list is long enough to note this possible development of events. 
In light of the above-presented observations, the rise of Russian socialism was neither an inevitable necessity nor a pure accumulation of coincidences. The history of this country included totalitarian social trends but it had also turning points marked by social counter-trends that balanced the impact of the totalitarian ones. Under the above circumstances, the course of the social evolution in Russia was influenced by secondary and circumstantial factors to a larger degree than usually. For this reason, Russian socialism was equally brought about by secondary and principal factors. 


\section{Ownership and Revolution in Non-Marxian Historical Materialism}

\section{On Some Basic Mechanisms of Social Development}

The present chapter offers a presentation of the basic models of socio-economic development in non-Marxian historical materialism. First, it discusses the mechanism of adaptive dependency manifested, for instance, by the dependency of a production organization system on the level of productive forces. Afterwards, it analyzes static assumptions and the evolution of a pure economic society. It constitutes the basic model of the theory of socio-economic evolution in n-Mhm because it aims to include fundamental development trends common for all three types of economic societies - slavery, feudalism, and capitalism. Finally, it offers a concretization of the basic model of a dual society, which purports to conceptualize the development of a feudal society, by including the influence of a periodic evolution of productive forces.

The second part of the chapter offers an expansion of the above models. I will present a non-Christian model of man (hereinafter referred to as $\mathrm{n}-\mathrm{Cmm}$ ), which set some limits to the assumption of rationality. Based on this anthropological presumptions, I will correct some static assumptions of the model of an economic society and modify its dynamic part.

\subsection{Adaptive Mechanisms}

In a common-sense interpretation of Marxism, the global relationships between productive forces and relations of production, a social base and a legal and political superstructure, social and economic conditions and particular states of social consciousness are interpreted in a causal way. That has been giving rise to wellknown interpretive difficulties, for it has not been clear how productive forces are to cause the appearance of particular relations of production, a social base of a legal and political superstructure, and social and economic conditions - of particular states of social consciousness.

Those difficulties have been solved by adaptive understanding of those dependencies. It is assumed that we were dealing with two states of affairs: state of affairs $A$, (from a set $\alpha$ called the set of possibilities) and state of affairs $B$ (from a set $\beta$ called the set of conditions). Let us assume that, in conditions $B$, state of affairs $A$ leads to state of affairs $x$. The set of those results (e.g. states of things $x$ and $y$ ) is ordered according to a particular property $k$ called a criterion of adaptation. 
Therefore, the distinguished states of affairs can be ordered according to the degree of the intensity of that property $k$. For example, state of things $x$ which is characterized by property $k$ to a greater degree will precede state of things $y$ characterized by $k$ to a smaller degree. The adaptation relationship between the elements from the set $\alpha$ and conditions $B$ of set $\beta$ with respect to property $k$ is defined as:

$$
A_{o p t}=a d_{k}(\alpha, B)
$$

and can therefore be read "out of the set of states of affairs $\alpha$ that one takes place which, under given conditions $B$, yields the result which has the property $k$ in the maximum degree; that state of affairs in $\alpha$ is denoted as $A_{\text {opt }}{ }^{" 299}$

Let us illustrate an adaptive dependency with the following example. A new device for increasing work efficiency and, what follows, the possibility of increasing a surplus product has been invented. Owners who compare various systems of the organization of production (traditional, invented by specialists, etc.) select the one, which they believe to be capable of ensuring the growth of a surplus product - with the use of that device. However, if the expected growth does not happen, the owners will still be looking for an advantageous system of the organization of production. If any of them delays the reorganization of production, that owner's profits from an additional surplus product will shrink and, in the end, the owner will go bankrupt. After a sufficiently long time, by trial and error, and the elimination of those who do not learn fast enough, an optimal system of the organization of production, with respect to the used tool, will become common in the observed economic sector. The mechanism of adaptation of systems of production to the level of productive forces, which operates in the above-described way, has been formulated by Nowak as follows:

(I) that system out of the set of historically given systems of production is adopted on the general scale which for a given level of productive forces ensures the greatest surplus product to be appropriated by the owners of the means of production. ${ }^{300}$

According to the above-mentioned formula, the criterion of adaptation is the maximization of a surplus product. The state of affairs $A_{\text {opt }}$ symbolizes the

299 Leszek Nowak, “The Theory of Socio-Economic Formations as a Theory of Adaptation Processes," in: Social Classes Action and Historical Materialism, ed. Leszek Nowak (Amsterdam-Atlanta GA: Rodopi, 1982), p. 115.

300 Nowak, "The Theory of Socio-Economic Formations," p. 113, 
optimal system of production, conditions $B$ are represented by the level of productive forces.

An adaptive mechanism merely assumes that an owner, who attempts to increase profit, chooses a production system from the available array of systems, which, to his/her knowledge, will ensure the highest profit. Owners, who, for some reasons, decide to postpone introducing the optimum organizational system, do not disappear but they will not acquire the highest profits. As a result, after a certain period of time, they will be eliminated as a result of economic competition. ${ }^{301}$

There is an analogous adaptive dependency between the superstructure and the economic base. On a mass scale, those systems, from among the various legal and political systems (traditional or invented by philosophers), become common which ensure the most effective introduction of the optimal system of the organization of production, from the point of view of the owners' class, given a particular state of the base. That dependency is formulated in the following way:

(II) that political system, from a set of historically given politico-legal systems, is adopted on a mass scale in a society, which ensures a system of the organization of production which is optimal for the ruling class, at a given level of the economic base.

The dependency of social consciousness on social being is similarly adaptive in nature. In this case, the interests of the owners' classes, guaranteed by the legal and political system, function as a selector of individual ideas. On a mass scale, such ideas become common as, in given social and economic conditions, they ensure the durability of a political system. That is expressed by way of the following dependency:

301 For a development of adaptive dependencies, see: Andrzej Klawiter, "Adaptation and Competition. A Contribution to the Classification of Adaptive Relationships," in: Dimensions of the Historical Process, ed. Leszek Nowak (Amsterdam-Atlanta, GA: Rodopi, 1989), pp. 129-146, Andrzej Klawiter, Krzysztof Łastowski, Leszek Nowak and Wojciech Patryas "Adaptation, Learning, Praxis. Some Applications of the Adaptive Conceptual Apparatus," in: Dimensions of the Historical Process, ed. Leszek Nowak (Amsterdam-Atlanta, GA: Rodopi, 1989), pp. 121-129; Michał Witkowski, "On Adaptive and Functional Dependencies. An Attempt at a Categorial Approach," in: Dimensions of the Historical Process, ed. Leszek Nowak (Amsterdam-Atlanta, GA: Rodopi, 1989), pp. 147-156. 
(III) those ideas, from a historically given set of ideas, become widespread on a mass scale which ensure, in given social and economic conditions, the highest stability of a legal and political system.

\subsection{The Mechanism of a Class Struggle}

The consequence of class inequalities in economy is a division of the newly produced value into variable capital allocated to the class of direct producers and surplus value kept by the class of owners. ${ }^{302}$ However, the system of appropriation of the surplus value does not necessarily lead to a class conflict in a given society. An economic antagonism understood in the above way results from a gap occurring between the level of economic needs of direct producers and the variable capital that is supposed to satisfy them.

Namely, when the level of an alienation of labor is low that is the majority of needs of direct producers is satisfied, the intensity of economic struggle is also low because the most of workers does not reason to protest. Social peace also prevails in the situation of high alienation of labor. Although most of needs of direct producers is not satisfied, poverty atomizes people, making them unable to any common protest. Therefore in the conditions of high alienation of labor, the intensity of economic struggle is also low. Revolution breaks out when the level of alienation of labor is moderately high. Then, exploitation becomes already painful for the most of the direct producers but it does not destroy their ability to common protests, yet. The dependency of class struggle from the level of alienation of labor can be demonstrated graphically in the following way:

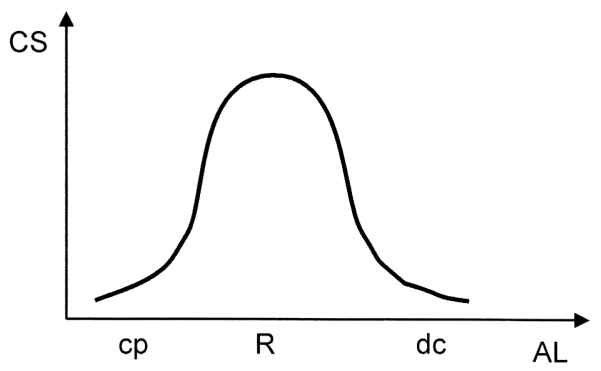

Fig. 9: The dependency of the level of class struggle on the alienation of labor. Explanations: CS- level of class struggle; AL - alienation of labor: $c p$ - interval of class peace; $R$ - interval of revolution, $d c$ - interval of declassation. 
To recapitulate the above insight, we could state the following:

(1) a state of class peace prevails when the most of the needs of direct producers is satisfied;

(2) a class struggle enters the stage of the highest intensity when the alienation of labor is moderately high; although exploitation becomes severe but it does not bloc a mass protest;

(3) a state of class peace prevails in the conditions of high alienation of labor because poverty breaks autonomous social ties and destroys the possibility of organizing mass protests.

Furthermore, I find it noteworthy that the statics of economic momentum, differently from the statics of political momentum, includes a single area of a revolution. This situation results from the fact that the statics of economic momentum is based on the assumptions of the "Christian model of man." The present chapter will offer a waiving out of these assumptions and their substitution with static assumptions derived from the anthropological theses of the "non-Christian model of man."

\section{On Two Models of Economic Society}

\subsection{The Basic Model of Purely Economic Society}

The idealizing assumptions of the basic model of an economic society adopt the existence of two social classes: owners and direct producers. Following from this, in this model, the influence of other social classes - rulers, priests, citizens, and believers is not taken into consideration in an explication of social processes. Additionally, the model disregards the impact of politics, culture, the institutions of public life and the collective consciousness of the participants of the economic life, on the social processes under investigation. The analyzed economic society is isolated from the outside, hence the model does not explain social phenomena with the influence of neighboring societies. The subsequent set of idealizing assumptions has an economic character. The adopted assumption is that level of productive forces is constant (technological advancement does not exist), hence, the number of branches of production does not increase and the accumulation fund in society equals to zero (simple reproduction takes place). Naturally, the list of idealizing assumptions is much longer. For instance, the model omits demographic phenomena associated with aa surplus or deficiency of workforce, uneven distribution of rare resources, etc. Generally speaking, the adopted 
assumption is that the model omits those factors, which have not been clearly introduced into it. ${ }^{303}$

Let us assume that, at the beginning of the phase of the increasing alienation of labor, social peace prevails. Initially, surplus value is increased by introducing more effective systems of organization of production. Under the operation of adaptive mechanisms, owners introduce more and more perfect organizational systems of production. However, the reaching of the optimal level of organization of production for the given level of productive forces is a lengthy process. When optimal, that is ensuring the highest surplus value, organizational system of production, becomes widespread, owners maximize their profit by introducing increasingly rigors systems of appropriation of surplus value. This, in turn, brings about a decrease of global value of variable capital assigned to the class of direct producers. As a result, both a divide between incomes of direct producers and profits of owners increase, a process which leads to the rise of the alienation of labor. When a certain threshold is exceeded - let us call it a threshold of class peace - singular acts of protest take place: productivity of labor decreases, direct producers leave work and strikes outbreak. A further rise of the alienation of labor brings about an intensification of the above acts of social protest. Finally, employees' mass demonstrations outbreak and the social system enters the phase of revolutionary disturbances. A revolution of direct producers may enforce an evolution of the ownership relations or it may transform into a social confrontation.

Let us now consider the first variant. A class of owners, deprived of the centralized means of coercion, gives way under the pressure of the revolution of the direct producers. However, an increase of variable capital assigned to the class of direct producers does not bring about a significant change. When the masses are calmed, the mechanism of economic competition results in yet another increase of the alienation of labor that, in turn, leads to a next rise of social disturbances.

In a long-term perspective, the only stable solution to a social conflict is a revision of ownership relations, namely, social ties connecting an owner and a direct producer. The level of economic power of an owner and, on the other hand, the level of economic autonomy of a direct producer depend on the number of decisions associated with production taken by an owner and the number of decisions taken by a direct producer. By transforming the ownership relations, owners partially give up their ownership prerogatives. As a result, direct producers receive more economic autonomy. A boost of an economic autonomy

303 Nowak, Property and Power, pp. 39-42. 
encourages direct producers to increase productiveness. As a result, they are able to secure higher income for themselves and to ensure an unchanged level of profit for the owners. A revision of ownership relations allows owners to reinstate social peace in their production units and to ensure uninterrupted acquisition of profit for themselves.

Some owners exit the phase of revolutionary disturbances by modifying the ownership relations. They grant more autonomy to direct producers what rises their productivity. In the consequence, the higher newly produced value can be divided into variable capital satisfying needs of direct producers and surplus value. The rise of income of direct producers in the progressive relations of ownership reinstates social peace. The remaining conservative owners also respond with a transformation of ownership relations connecting them with direct producers. Thus, in the phase of evolution in ownership relations, a gradual transformation of ownership relations takes place. As soon as the most of total product is produced within the new progressive ownership relations, a shift into a new socio-economic formation is completed. According to the model of social evolution, the emergence of new socio-economic formation implies a transformation of ownership relations in a given society.

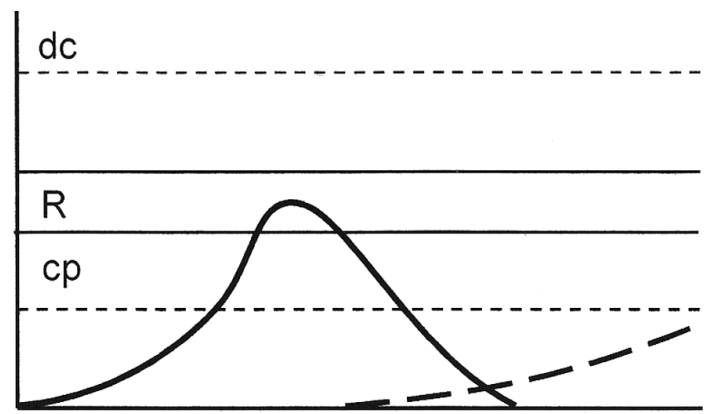

Fig. 10: Development of an economic society (the standard no-loop variant). Explanations: $c p$ - threshold of class peace; $R$ - revolutionary area; $d c$ - threshold of declassation; solid line - level of economic alienation; dotted line - evolution of ownership. Henceforth, the above key will be used.

Let us now consider the second variant where a revolution transforms into a social confrontation. ${ }^{304}$ The absence of the centralized means of coercion does 
not preclude the existence of dispersed means of coercion at the owners' disposal. If owners decide to violently suppress revolutionary protests, they will allow for a declassation of direct producers. Declassation paralyzes the working class and prevents resistance, allowing owners to advance exploitation. However, in the state of unlimited exploitation and dissatisfaction of the greater part of needs of the direct producers, their productivity decreases. As a result, owners acquire lower profits, which works against the interest of this class. However, a mere increase of income of direct producers restores their readiness to take up social resistance. A repeated application of force brings about another declassation of direct producers and, once more, brings direct producers to poverty, which, in turn, causes a decrease in their productiveness and in profits expected by owners. For this reason, the only possible permanent solution is a revision of ownership relations, which awards an increased productive autonomy to direct producers bringing about a boost of their productiveness. If an economic revolution is lost on the part of direct producers, a society experiences a delayed evolution of ownership relations.

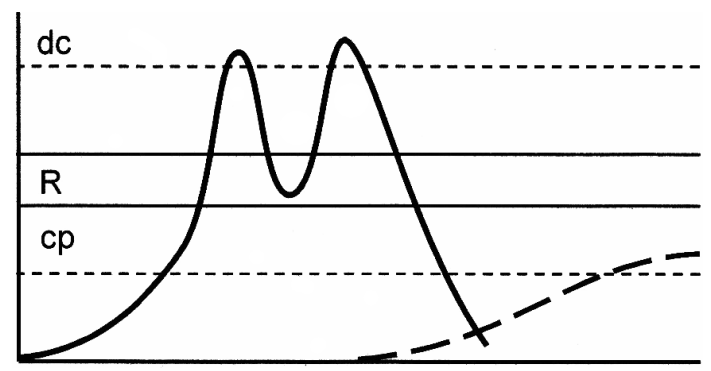

Fig. 11: Development of an economic society. Confrontational variant of a defeat.

Alternatively, a working class can gain victory in a social confrontation. As a consequence, a class of owners is eliminated and local revolutionary communities acquire control over the means of production. However, under the mechanism of economic competition, the victorious working class will divide internally into new employee elites, which will monopolize control over the means of production, and into masses. By seizing control over the means of production, revolutionary elites transform into a new class of owners. The new class of owners will repeat the actions of the old one. It will increase profit to maximum - initially, by means of organizational advancement, and later by means of appropriation of surplus product. Boost of alienation of labor brings about revolutionary outbursts of direct producers, 
forcing the new class of owners to revise ownership. In other words, a workers' revolution targeted at the new class of owners ends a labor loop.

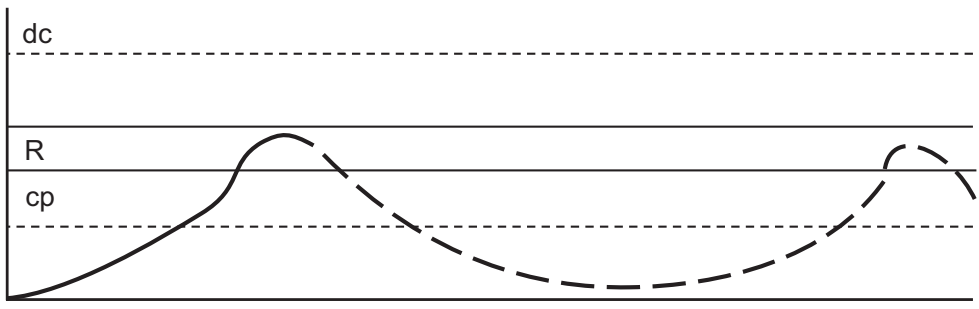

Fig. 12: Development of an economic society: a single labor loop variant.

To sum up, all variants of the evolution of an economic society - victory or loss of employees' revolution and revolutionary disturbances enforcing a revision of ownership relations - reach the same social result, namely, an evolutionary transformation of ownership relations. The development of an economic society can be demonstrated in the Figure 12 .

The basic model of an economic society is supposed to explain the most fundamental developmental trends of each socio-economic formation. ${ }^{305}$

The counterpart of the phase of the increasing alienation of labor in slavery formation is period of patriarchal slavery which gradually transformed into classical one or the exacerbated serfdom of the peasantry introduced in the feudalism. The process of worsening of the economic situation of slaves or peasants brought about social movements, a rise of slaves in the 2 nd and the 1 st centuries B.C., and peasant wars and riots of urban commoners in the 14th and the 16th centuries in Europe, which, in light of the model, one may interpret as economic revolutions. In the consequence of social disturbances, new ownership relations were emerged. An institution of colonate was prototypic to feudal relations in a slavery society. The owners of great estates settled free people as lease-holders (colonus) on their arable lands. After paying the rent, the coloni could keep the

305 For alternative models of a socio-economic formation constructed on the basis of the idealizational method, see: Piotr Buczkowski, "Toward a Theory of Economic Society. An Attempt of at the Adaptive Interpretation," in: Social Classes Action and Historical Materialism, ed. Leszek Nowak (Amsterdam-Atlanta GA: Rodopi, 1978), pp. 158210; Krzysztof Łastowski, "The Theory of Development of Species and the Theory of Motion of Socio-Economic Formation," in: Social Classes Action and Historical Materialism, ed. Leszek Nowak (Amsterdam-Atlanta GA: Rodopi, 1978), pp. 122-157. 
rest of income for themselves. Afterwards, a prototype of capitalist ownership in a feudal formation was a tolling agreement system in craft and free lease of land in agriculture. A socio-economic evolution brings about a growing autonomy of direct producers - a capitalist worker is more liberated than an urban commoner or a serf, and the latter two enjoy more freedom than a typical slave.

\subsection{An Economic Model of Feudal Society}

The basic model of an economic society explains fundamental developmental trends common to all socio-economic formations. However, to acquire satisfactory approximation of a feudal society, one has to further concretize the model of an economic society. The model of a feudal economy within n-Mhm assumes a periodical growth of productive forces and a emergence of new domain of production. The above take place in the final stadium of the phase of the increasing alienation of labor. Let us now present a much-simplified model evolution of a feudal economy. ${ }^{306}$

In the first stadium of the phase of the increasing alienation of labor, the class of owners maximize surplus value, initially by means of organizational advancements, subsequently by means of a gradually growing reduction of variable capital. For this reason, the alienation of labor increases at this stage of social development. The gradual advancement of exploitation causes an increase of social tensions. However, the stage of growing social conflict and revolutionary disturbances takes a different course in comparison to the corresponding phase of social evolution in a standard economic society. In the final stadium of the phase of the increasing alienation of labor, there occurs a periodical growth of productive forces and a new domain of production is established. Initially, in the new branch of production there is a lower level of alienation of labor in comparison to the old one. Direct producers faced with the choice between migrating to the new production sector, or engaging in a revolutionary confrontation in the old sector of production, migrate to the new economic domain. Migration of the most rebellious workers to new branch of production, characterized by a lower alienation of labor, automatically defuses the conflict situation in the old sphere of the economy.

This results in a creation of a dual society. Owners of the old sphere of economy, in order to prevent further migration of direct producers to the new economic sector, shift the division of live production to the benefit of workers. After a certain period of time, the level of alienation of labor decreases in the old economic sector. Simultaneously, the new production area undergoes a process

306 Nowak, Property and Power, pp. 78-100. 
of division into the class of owners and the class of direct producers. Under the influence of the standard mechanisms of economic competition, the level of exploitation increases also in the new economic sector.

The above model assumes that the economy of the society under study is of a parasitic character. For this reason, expanded reproduction depends on the growth of owners' personal consumption. Thus, an increase of fund of luxury $(M)$ constitutes the fundamental condition for economic growth. One has to assume that after the division of the economy, both economic subsystems become parasitic. The conditions for a development of effective demand in both fields separately can be demonstrated in the following way:

$$
\begin{aligned}
& D_{o}=C_{o}+V_{o}+\left(M_{o}{ }^{\mathrm{k}}+\Delta M_{o}{ }^{\mathrm{k}}\right) \\
& D_{n}=C_{n}+V_{n}+\left(M_{n}{ }^{\mathrm{k}}+\Delta M_{n}{ }^{\mathrm{k}}\right)
\end{aligned}
$$

Each of the separate branches of production creates effective demand for the second one. The external component of the effective demand for the new branch of production is the increase of the constant capital in the old domain $\left(\Delta C_{o}{ }^{n}\right)$, an increase of variable capital $\left(\Delta V_{o}^{\mathrm{n}}\right)$, and the growth of the fund of luxury $\left(\Delta M_{o}^{\mathrm{n}}\right)$ manufactured in the new production area. Naturally, the above objects cannot be supplied but the old branch of production. For this reason, the demand for production of the new branch is a sum of external and internal effective demands. Consequently, the effective demand for the production of the new domain of production includes:

$$
D_{n}=M_{n}+D_{o}
$$

In a corresponding way, the effective demand on the goods of the old domain of production includes internal demand determined by an increase of luxury fund and external demand determined by the new domain of production:

$$
D_{o}=M_{o}+D_{n}
$$

Initially, the old sphere of production visibly dominates the new one. Then, the demand of the old economic sector determines the volume of the effective demand on the goods manufactured in the new production area. Following from this, the growth of its own luxury fund ceases to be the principal stimulator for the new production sphere. In the phase of the splitting of the society, the demand of the old sphere of production becomes the principal stimulator and the owners of the new sector begin to accumulate, instead of consummating. Importantly, satisfaction of the external effective demand (of the old sphere) depends on the level of accumulation. In the old branch of production the external effective demand does not play an equally important part, as the increase of old owners' luxury fund. Developmental perspectives of each of the 
production areas are determined by the relation between the growth of effective demand $D_{N}$ on goods manufactured in a given domain of production and the production size of a given domain $P_{N}$. The developmental perspective of the new production domain is manifested by the following ratio:

$$
P_{N}=\Delta D_{N} / P_{N}
$$

Correspondingly, the perspective of the old domain of production is manifested by the following quotient:

$$
P_{o}=\Delta D_{o} / P_{o}
$$

The production sphere that has a better perspective for development will develop more dynamically and will in time dominate the economy of a given society.

However, developmental perspectives of each of the economic domains influence the evolution of class relations inside separate economic areas only to a small extent. A decrease in income of the class of owners of the old production area brings about counteraction - an attempt at lowering the income of direct producers. For this reason, within this economic system, the alienation of labor grows and, in turn, brings about an increase of social conflict.

Correspondingly, standard economic mechanisms bring about an increase of the alienation of labor in the new branch of economy. Providing the level of exploitation exceeds a certain threshold - a threshold of class peace, social disturbances outburst and soon transform into mass revolutions of direct producers.

Following from this, revolutionary disturbances take pace in both economic subsystems. Revolutions may outbreak simultaneously in both areas, or they may outbreak separately. Since this time, the level of productive forces is constant, a revision of ownership relations may bring a solution of the social conflict. Following from this, progressive rules of ownership relations emerge in the new and old production areas. By granting additional autonomy to direct producers, they stimulate a boost of productivity. However, a shift into the new socio-economic formation does not only depend on an internal evolution of types of ownership in each of the economic subsystems, but also on the process of domination of the progressive ownership relations of one of the economic subsystems over the progressive rules of ownership of the second subsystem. This domination depends on the developmental perspective of a given domain of production. As a result that progressive rules ownership relations become widespread in society at large which domain of production has better developmental perspective. As a result, a dual society retransforms into a unitary society.

The above model is capable of providing a more detailed explanation of some of the developmental trends that characterize a feudal economy. I will 
now present a much-simplified historical illustration of the model assumed by $\mathrm{n}-\mathrm{Mhm}$. The final decay of slavery-based economy took place approximately in the 4 th and the 6th centuries. Slavery was then substituted with an institution of colonate. Coloni leased farmland from landowners and, in exchange, they paid back with a portion of their crops and money. Additionally, coloni were forced to provide various craft services. The introduction of the institution of colonate on the mass scale brought about a naturalization of the economy and a disappearance of towns in a slavery-based society. The class of feudal lords that emerged from the class of slave owners had subjugated the class of peasants until the 10th century. A feudal lord had land power (he was a landowner of the farmland cultivated by a peasant), personal power (he was in control of a direct producer), and judicial power (he could decide on legal cases involving a peasant).

Together with a number of advancements in the field of craft production, technological advancements at the turn of the 10th and the 11th centuries - such as the invention of an iron plough, the introduction of the three-field system, and the horse collar used for ploughing - laid the foundation for the separation of a new production field of an urban economy. The technological aspect of a dual economy was a growth of productive forces. The social aspect of the process of creation of the new branch of production was merely an acquisition of an adequate size of a productive force. At the turn of the 10th and the 11th centuries, a considerable number of peasants migrated to towns in order to improve their economic situation, since towns offered significantly more beneficial conditions for earning. Initially, towns enjoyed the same privileges, as rural settlements, but during the 10th and the 11th centuries they earned autonomy and selfgovernance, frequently in the course of bloody battles with the feudal class.

Feudal lords, in order to prevent a mass escape of peasants to towns, decided to mitigate serfdom relationships in rural areas. They substituted corvée with rent and accepted the peasants' freedom to move. The above concessions beneficial to the peasantry allowed this social class to acquire higher income. However, in a long-term perspective, the above concessions brought about a decrease of income of the nobility.

After the period of transformation of town economy, the mechanisms of economic competition subjected this production area to the processes of growing alienation of labor. In these terms, one can interpret the development of the guild system, which limited the independence of apprentices and gave almost unlimited abilities of exploitation of workers. In some branches of the craft a working day lasted for 15-16 hours. The process of lowering income of the apprentices and prolonging the working day brought about a rise of the opposition of direct producers employed in craft workshops. The protests of this social group were 
manifested in strikes and demonstration of urban commoners that grew in size in the 13th and the 14th centuries.

Corresponding processes took place in the agricultural system. A decrease of income of the feudal lords, enforced by the development of the urban production area, brought about a counteraction of this social class. However, peasants responded with an increased opposition to the repeated attempts to enforce subjugation and to increase the scope of serfdom. A number of riots of rural populations and urban commoners took place in various Western-European countries in the 14th and the 16th centuries. For example, in France peasant riots started in 1358 and demonstrations of urban commoners took place in a number of towns in the years 1381-1382, and in Germany riots of urban apprentices in a number of major towns in the German Reich lead to a peasant war that erupted in 1525. In light of the model of a feudal economy, the above events may be interpreted as an economic revolution of direct producers of both economic subsystems. As the model suggests, these revolutions were supposed to bring about a development of progressive ownership where direct producers would enjoy a higher level of production autonomy. One may perceive the appearance of individual land lease agreements and a spread of a tolling agreement system, together with the subsequent manufacturing system that abolished the limitations of the guild system, as manifestations of a progressive ownership. As a result, the development of capitalist ownership was initiated within a feudal economy. This process was most visible in England. Abolishment of serfdom brought about a deficit of workforce, which was searching for work in towns. As a result, landowners had to resign from producing crops and develop sheep breeding that required a lower number of direct producers. This brought about changes in the structure of agricultural ownership. Land was being fenced, common landownership was liquidated, and poorer peasants were being expropriated. Agriculture became an industrial branch specializing in production of goods sold at a market. This brought about a subordination of the structure of agricultural ownership to the system of ownership of the domineering economic system. Thus, the diffusion of progressive ownership of the domineering economic subsystem determined a transformation into a capitalist economy.

I find it noteworthy that a feudal model in n-Mhm basically approximated only the development of Western European societies. This model does not explain the developmental mechanisms of Central Europe because the conceptual apparatus of this theory is too rough to grasp the developmental trends of the societies in this part of Europe. I am particularly discussing here the issue of dualism in the socio-economic development of Europe and a creation of the manorial-serf system east of the river Elbe. On the one hand, this system 
undermined the evolution of the new economic sphere, while on the other hand, it limited the level of production autonomy of the peasants, by exacerbating serfdom. For a period of time - usually the 16th century is listed in this regard Central Europe had been evolving in line with other developmental regularities, in comparison to Western Europe. In order to explain these regularities, one has to further develop n-Mhm model of social development.

\section{On Two Types of an Economic Revolutions}

\subsection{Non-rationalistic Model of a Man}

Macro-social dependencies between rulers and a class of citizens are derived from anthropological presumptions based on non-Christian model of man (hereinafter referred to as $\mathrm{n}-\mathrm{Cmm}){ }^{307}$ This brings about a differentiation of two areas of revolutions in a political theory. On the other hand, a Christian model of man (hereinafter as $\mathrm{Cmm}$ ) provides anthropological grounds for a formulation of the second type of social dependencies - macro-economic regularities. This way, one can distinguish only one revolutionary area in the statics of the theory of economic momentum. Corresponding differences occur in the dynamics of the theories of the two domains of public life: politics and economy. Following from this, $\mathrm{n}-\mathrm{Mhm}$ in its current form assumes two models of man - one based on a $\mathrm{Cmm}$ and the second adopting the assumptions of $\mathrm{n}-\mathrm{Cmm}$. In order to avoid the allegations of internal conflict, I will attempt to draw also the economic dependencies from the anthropological presumptions of non-Christian model of man.

First, I would like to offer a review of the reconstruction of the anthropological assumptions creating a "Christian model of man." Second, I will provide arguments proving that the critique of the anthropological assumptions of Christianity offered by Leszek Nowak is inaccurate. As a result, the terms "Christian" and "NonChristian" model of man will become meaningless. Hence, I will substitute them with the terms "rationalistic" and "non-rationalistic" model of man.

The two anthropological conceptions - first, adopted by the Gospel (according to Nowak) and the second that is supposed to offer a positive critique of the first - refer to terms and language of a particular axiological concept. ${ }^{308} \mathrm{I}$ will now briefly present its main ideas. May the relation of preference of person $A$ allow ordering a set of states of affairs in the following way:

$$
\mathrm{p}_{-m}, \ldots, p_{-2}, p_{-1}, p_{0}, p_{1}, p_{2}, \ldots, p_{n}
$$

307 Nowak, Power and Civil Society, pp. 3-20.

308 Nowak, Power and Civil Society, pp. 8-10. 
The above sequence is a value $W$ of person $A$, and the following states of affairs are cases of value $W$. The states of affairs $p_{1}, \ldots, p_{n}$ are positive cases $(\operatorname{good}$ of $W$ type) for person $A$, and the states of affairs $p_{1}, \ldots, p_{n}$ are negative cases (bad of $W$ type) of person $A$. The state of affairs $p_{0}$ is a neutral state for person $A$.

According to the conception recapitulated above, the benevolence of person $B$ toward person $A$ is $B$ ' tendency to realize the goods of $A$, whereas the hostility is of person $B$ to realize states of affairs that person $A$ considers to be evil.

Nowak claims that the Christian ethics is founded on the virtue of love for our neighbor, moreover, love for our enemies. In the reconstruction presented above, certain anthropological theses, which originate from the above moral guidelines, are formulated on the basis of the principle of love. According to Nowak:

the foundation of every principle is a recognition of the factual state, thus, some given knowledge of the reality. Only on the grounds of this knowledge, it orders people to behave in a way that is supposed to bring about a transformation of "what is" into "what should be." One says "don't smoke" to a person who he/she knows to be smoking and whom, one believes, will benefit from hearing this advice. In more general terms, one who establishes the general principle "all people should do $C$," assumes a quite general descriptive statement that people are not willing to voluntarily behave in $C$ way, but that if they became aware of the responsibility to behave this way, they will implement the behavior. These types of statements, particularity the ones associated with universal ethical systems, straightforwardly assume a particular vision of the human nature, or a philosophical anthropology. ${ }^{309}$

In this regard, the principle of love for our neighbor is supposed to assume: "The mutual attitudes of both considered- arbitrary but typical - individuals are formed on the basis of a linear relationship. The more hostile individual $A$ is toward individual $B$, the more hostile $B$ is toward $A$, while the kinder $A$ is toward $B$, the kinder $B$ is toward $A .{ }^{\prime 310}$

The author of the reconstruction under investigation argues that this context is necessary to discover the epistemological value of the principle "love your enemies." Nowak repeats after Gombrowicz that the behavior of other people determines the human nature. Hatred and anger are perceived as a wrong reaction to evil faced in everyday life. According to the analyzed interpretation of the Gospel, everyone can be "saved by God," or liberated from the condition of hatred in which he/she is entangled if he/she comes across people who will

309 Nowak, Dynamika władzy, pp. 28-29, see also: Nowak, Power and Civil Society, pp. 6-7.

310 Nowak, Power and Civil Society, p. 10. 
show him/her benevolence. In response to the received goodness, the evildoer will respond with kindness toward someone else.

However, Nowak claims that the theoretical concept behind the New Testament has two significant limitations. In particular, hostility is supposed to reciprocate for moderate evil that we face in everyday life. However, in the face of extreme life-endangering enmity, one is not supposed to respond with hostility toward his/her evildoer, but with kindness, since kindness keeps him/her safe. To put it in more technical terms:

Beyond a certain range of hostility of person $A$ to person $B$, at which the reflexive hostility of $B$ to $A$ reaches the highest level (let us call it the spectrum of rebellion of $B$ against $A$ ), any further growth of $A$ 's hostility to $B$ - that is, the tendency of $A$ to produce constantly larger threats to $B$ - entails the decrease of the reflexive hostility, that is, to carry out what oppressor considers to be good, or, in other words, to realize his preferences. ${ }^{311}$

In the situation of enslavement, person $B$ behaves in accordance with preferences of person $A$, instead of implementing his/her own preferences. Nowak argues that, in this situation, the principle "love your enemies" is supposed to act as an order consolidating submissiveness and devotion to the malefactor. In this area of interpersonal relations, the ethics of love should be substituted with the ethics of rebellion.

A corresponding situation should occur at the opposite end of interpersonal relations. Kindness is an appropriate response to kindness of others up until a certain point. After a certain threshold is exceeded,

when the size of gift continues to increase, when constantly higher goods are realized for us, the situation begins to change. Our tendency to reciprocate kindness with kindness disappears; we return the growing goodness with a constantly lesser one. Finally, in the truly extreme case, when someone realizes for us the highest good, it turns into the attitude, which, as in the Russian saying "s zyru biesit'sa," we will call the attitude of satanization. This attitude consists in responding to the greatest benevolence with hostility, or, in order words, acting according to the counter-preference of our benefactor. ${ }^{312}$

In the area of satanization, the principle of love for our neighbor, designed to forbid people from hurting others, consolidates the attitude of satanization. A satanized person behaves according to counter-preferences of his/her benefactor instead of satisfying his/her own preferences. In this area, as Nowak

311 Nowak, Power and Civil Society, pp. 11-12.

312 Nowak, Power and Civil Society, p. 13. 
claims, the Christian principle of love for our neighbor should be substituted with the ethics of social severity.

To recapitulate, one can say that the non-rationalistic model of man assumes there are three areas of interpersonal relations and three separate ethical systems. In the normal area the rule of reciprocity prevails. Individual $A$ responds with hostility to the hostile behavior of his/her interacting partner - individual $B$. The highest levels of enmity expressed by $A$ toward $B$ may be termed a rebellion of individual $A$ against $B$. For every $A$ there is a threshold of hostility - when individual $A$ faces extreme enmity and he/she becomes inclined to implement the preferences of individual $B$, instead of continuing his/her hostile behavior toward $B$. In the area of enslavement, under the influence of extreme enmity, an individual resigns from realizing his/her own preferences and adopts the preferences of his/her partner in a social interaction. In this area, the ethics of love for one's neighbor should be substituted with the ethics of revolution.

An analoguous situation takes place at the opposite end of the area of interpersonal relations. Individual $A$ also responds with kindness to kindness received from $B$. However, every $A$ has a threshold of kindness. When faced with extreme kindness, individual $A$ ceases to respond with kindness. In the final stadium of the process, his/her behavior transforms into a "pathological" enmity toward the interacting partner. In the area of satanization an individual does not behave in line with his/her own preferences, but with the counter-preferences of her/his interacting partner. In this area, the ethics of love for one's neighbor should be substituted with the ethics of social severity.

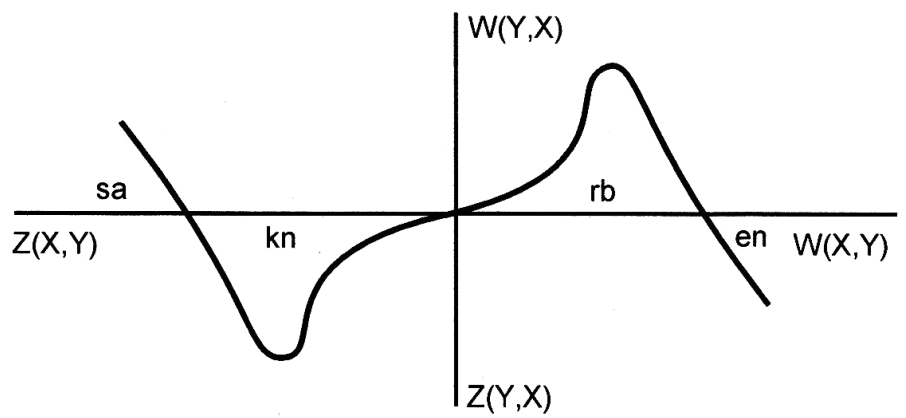

Fig. 13: Non-rationalistic model of man. Explanations: $W(X, Y)$ - hostility of $X$ toward $Y ; W(Y, X)$ - hostility of $Y$ toward $X ; Z(X, Y)$ - benevolence of $X$ toward $Y ; Z(Y, X)$ benevolence of $Y$ towards $X ; s a$ - area of satanization; $l n$ - area of kindness; $r b$ - area of rebellion; en - area of enslavement. 
The above concept allows for distinguishing a number of peculiar attitudes. A person with a steadfast attitude resists enslavement regardless of the range of the experienced evil. In turn, a person with a pious attitude will not become satanized regardless of the range of experienced goodness. Interpersonal relations described by the non-rationalistic model of man are be demonstrated graphically in the previous page 222 .

\subsection{Critique of the Reconstruction of a Christian Model of Man}

When commenting on the reconstruction of a Cmm offered by Leszek Nowak, it is noteworthy to consider the methodological status of the conception. According to Nowak, the adaptive interpretation attempts to solve:

the same kind of substantive problems the historical author of the given conception under interpretation was trying to solve. If, then, it is necessary to turn the author's hierarchization of motives upside down, if it is necessary even to eliminate some of them in order to obtain the solution the historical author failed to achieve, then all that is admissible. For regulative interpretation, the author's ideas are the intellectual point of departure for making a theory of the world. And normally this regulative interpretation is not very helpful in discovering the contents of the author's mind when he was engaged in the same type of occupation some time ago. ${ }^{313}$

However, in this case the question is to what extent the interpreter is allowed to modify the structure of the lines of thoughts of the investigated conception? And how to define the line between a concept that is an interpretation of a viewpoint of a given author and a concept that merely draws inspiration from someone else's thought material. To help establish this difference, one may assume that the body of works of the interpreted author consists in a number of motives. One may distinguish between principal and secondary threads. In a historical interpretation, an interpreter adopts the author's standpoint on the structure of his/her own thought. However, in an adaptive interpretation of someone else's thoughts, an interpreter has the right to modify a hierarchical order of motives. If the modification occurs in the area of motives belonging to the class of principal motives, it is an interpretation. However, if while working on someone else's body of work, an interpreter modifies motives from the area of motives established by the author to be secondary, i.e. if he/she decides that the motives perceived by the author to be secondary, are indeed principal, than this is not an

313 Leszek Nowak, "Remarks on the Christian Model of Man and the Nature of Interpretation," Social Theory and Practice. An International and Interdisciplinary Journal of Social Philosophy, No. 1 (1989), p. 110. 
interpretation. One may say that an initial concept is inspiration for a subsequent concept. According to this approach, the Gospel inspired Nowak's model (due to the reduction of theological motives).

The above differences become apparent in paraphrasing of the two methods of reading someone else's thoughts. If one paraphrases an interpretation of the views of a given author and discovers them to be false according to the paraphrasing concept, then the interpreted author is held accountable. However, if one paraphrases a concept that draws inspiration from other author's concepts and discovers it to be false according to the paraphrasing concept, then the source of the inspiration is not held accountable (due to too large discrepancies between the original and the interpretation) but the one inspired by someone else's views.

Since the Gospel is the sole inspiration for a $\mathrm{Cmm}$, Nowak's idea that "an ethic universal for the entire area of interpersonal relations does not exist, or, at least, it is not the Christian ethic" 314 is unjustified. Thus, in order to avoid worldview implications, I shall use the terms "rationalistic" and "non-rationalistic" model of man to describe the two concepts of man in the further part of the present book. $^{315}$

314 Nowak, Dynamika władzy, p. 41.

315 For a critical discussion of a non-Christian model of man, cf.: Wojciech Lamentowicz, "Kilka uwag polemicznych," in: Nowak, Władza. Próba teorii idealizacyjnej (Warszawa: In Plus, 1988), pp. 184-191; Adolfo Garcia de la Sienra, “The Christian Model of Man: Reply to Nowak," Social Theory and Practice. An International and Interdisciplinary Journal of Social Philosophy, Vol. 15, No. 1 (1989), pp. 89-107; Robert Egiert, "Toward the Sophisticated Rationalistic Model of Man," in: Social System, Rationality and Revolution, eds. Leszek Nowak and Marcin Paprzycki (Amsterdam: Rodopi, 1993), pp. 215-233; Katarzyna, Paprzycka and Marcin Paprzycki, "How Do Enslaved People Make Revolutions," in: Social System, Rationality and Revolution, eds. Leszek Nowak and Marcin Paprzycki (Amsterdam - Atlanta, GA: Rodopi, 1993), pp. 251-265; Marcin Paprzycki, "The non-Christian Model of Man. An Attempt at a Psychoanalitic Explanation," in: Social System, Rationality and Revolution, eds. Leszek Nowak and Marcin Paprzycki (Amsterdam - Atlanta, GA: Rodopi, 1993), pp. 205-215; Mieszko Ciesielski, Zagadnienie ograniczeń racjonalnego modelu działań ludzkich, Próba ujęcia działania nawykowo-racjonalnego (Poznań: Wydawnictwo Poznańskie, 2012), pp. 72-99, and Mieszko Ciesielski, "Leszek Nowak's non-Christian Model of Man and Inderdisciplinarity of Humanities," Studia Europea Gnesnensia, No. 7 (2013), pp. 87-111. 


\subsection{A Non-rationalistic Model of Man in the Area of Economy}

I shall now return to the underlying theme of the present chapter, namely, the macro-social economic dependencies derived from the assumptions of a nonrationalistic model of man.

Let us take a closer look at a political theory. It is capable of expressing the global concept of control and domination. ${ }^{316}$ It may be stated that $B$ has control over $A$ if he/she is able to impose on every alternative decision of a certain type a sanction unfavorable to person $A$. The domination of $B$ over $A$ is manifested in social situations crated by $B$, in which $A$ adopts $B$ 's system of preferences. In political life, social impact is expanded directly - through control over the means of coercion. Static assumptions of a political theory comprise of three areas of the relation between authorities and a class of citizens. In the first, central area social peace prevails. Civil alienation, which demonstrates the ratio of actions of citizens to all actions, is small and revolting people also constitute a small percentage. However, if the sphere of regulation rises, civil social resistance also increases in order finally to enter the area of the revolution of the first kind. A further increase of the sphere of regulation disrupts independent social ties. In an atomized civil class, the ability for resistance disappears completely, which causes the citizens to spontaneously adopt preferences of the rulers. However, as civil alienation continues to grow and a complete totalization of civil society becomes a threat, one of the peculiar attitudes becomes widespread - the steadfast attitude what brings about a revolution of the second kind.

A corresponding situation takes place at the opposite end of the area of the relation authorities - civil class. The level of social alienation, manifested by the "the relation between the number of social actions undertaken in the state of satanization and the total number of actions," 317 is indicative of the state of class peace in the relations between authorities and civil society. In this area, there is also a low level of consensus, indicated by the percentage of citizens in the state of kindness toward the authorities. However, an increase of the number of actions undertaken in the state of satanization raises the level of social consensus - power becomes the sole guarantor of social peace. An increase of social alienation, or a growth of the percentage of satanized actions, disrupts the foundation of all types of social ties, even the autonomous ones. At this stage one of the peculiar attitudes diffuses in a society - the pious attitude, which leads

316 Nowak, Power and Civil Society, pp. 21-23.

317 Nowak, Power and Civil Society, p. 32. 
to the area of solidarity of the second type, which protects the society from an anomie. $^{318}$

The above dependencies can be demonstrated graphically in the following way:

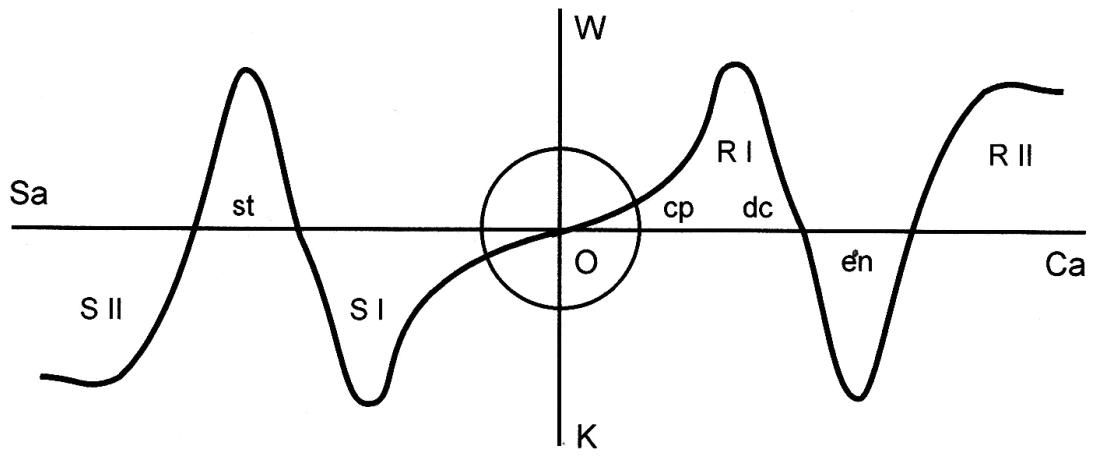

Fig. 14: Relation power - civil society. Explanations: $W$ - level of resistance; $K$ - level of consensus; $\mathrm{Ca}$ - civil alienation; $\mathrm{S} a$ - social alienation; $S$ II - the second solidaristic area; $s t$ - area of satanization; $S$ I - the first of solidaristic area; $O$ - circle of public order; $c p$ area of class peace; $R I$ - the first revolutionary area; $d c$ - area of declassation; $e n$ - area of enslavement; $R I I$ - the second revolutionary area.

I would like to apply above-presented anthropological presumptions to an economic sphere. One can formulate the concept of economic control and domination. In an economic sphere, the process of enlarging social impact is indirect because it occurs via system of appropriation of surplus product. A negative sanction imposed on $A$ (a direct producer) is a decrease of his/her income by $B$ (owner). By determining the size of income acquired by $A, B$ brings $A$ to failure or to undertake certain actions preferred by $B$ - i.e. to combine productive forces $A$ with the means of production. On the other hand, the domination of $B$ over $A$ occurs when $A$ is in an economic situation when he/she adopts also the preference system expressed by $B$. The relations based on economic control or domination are asymmetrical. Control over a certain type of material means allows $B$ to impose on some $A$ 's action negative sanction. $A$ is deprived of such possibilities - i.e. refusal to work (I omit here extraordinary cases of a social revolution).

Hence, if the non-rationalistic concept of man serves as the foundation basis for drawing global economic dependencies, then in the static image of the 
relation of ownership - the class of direct producers - one could distinguish the area of class peace, economic declassation, and revolution of the first and the second kind. I will limit my analysis to the above interpersonal relations.

On a micro-social level, in the area of class peace prevails the principle of reciprocity: "the higher the income, the more productive the labor." In this area, social peace prevails since the most of the economic needs of direct producers is satisfied.

However, when the income of direct producers drops, their productivity decreases. On a micro-social level, in the area of an increase of intensity of social struggle the principle of reciprocity may be defined as "the lower the income, the lower the effectiveness of labor." A drop in productivity brings about a decrease of profit of owners. To protect themselves against the decreasing profitability, they introduce further limitation of the variable capital assigned to direct producers. However, a decrease of income of direct producers additionally lowers the productivity of labor and, in a limit case, brings about to a refusal to combine workforce of direct producers with the means of production. Following from this, the revolution of the 1st kind outbreaks when exploitation reaches a moderately high level it becomes painful, but it does not erase the ability to organize mass incidents.

In the area of declassation, a further decrease of income of direct producers brings about a spread of the attitude of "pathological productiveness." On the micro-social level, the principle of behavior derived from the above attitude may be expressed in the following way: "the lower the income, the higher the effectiveness of work." The spread of this attitude among direct producers is, on the one hand, a way of protecting against extreme poverty and, on the other hand, a result of disappearance of the mechanisms of class resistance, since poverty disrupts all autonomous interpersonal relations, which, in turn, obstruct the ability to organize mass incidents.

For this reason, social peace prevails in the area of declassation. However, this is not a permanent state. If the exploitation of direct producers grows substantially and the income ceases to satisfy even the most fundamental needs that determine the biological existence of the class, one of the peculiar attitudes becomes widespread in a society - the steadfast attitude. Let us recall that the steadfast attitude characterizes an individual who, regardless of the scope of experienced evil, does not subordinate to someone else's authority. The diffusion of this type of attitude brings about a revolution of the second kind, which prevents the threat of biological degradation of a society, namely, an extreme level of dissatisfaction of needs.

In short, social peace prevails in a situation of low alienation of labor, when the most of needs of direct producers is satisfied, and a situation of high alienation, 
when exploitation reaches the extent in which it obstructs the ability for mass protests. Revolutionary protests erupt when the alienation of labor is moderately high (revolution of the first kind) or extreme (revolution of the second kind). In the first case, a revolution begins when exploitation becomes painful, but it does not yet suppress the ability to organize mass protest. In the second case, riots occur when the scope of exploitation endangers biological survival of direct producers. The above dependencies can be demonstrated graphically in the following way:

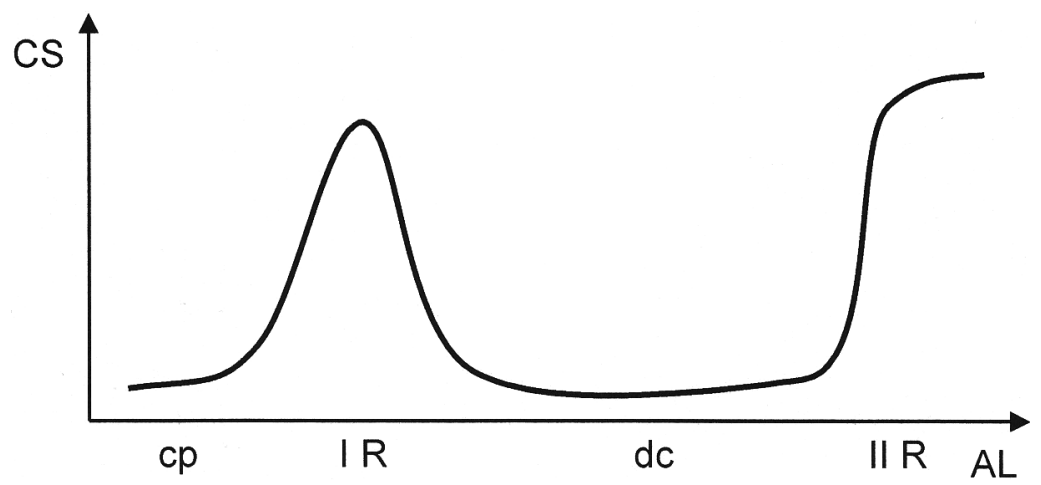

Fig. 15: The dependency of the level of class struggle on the alienation of labor. Explanations: CS - level of class struggle; $\mathrm{AL}$ - alienation of labor: $c p$ - interval of class peace; I $R$ - interval of revolution of the first kind, $d c$ - interval of declassation II $R$ interval of revolution of the second kind.

Incorporation of the above-presented presumptions of the non-rationalistic model of man to the theory of economic society modifies the its static assumptions. Most significantly, one may distinguish two kinds of revolution in the statics of economic momentum. ${ }^{319}$ Metaphorically speaking, a revolution of

319 We may assume that similar macro-economic dependencies occur on the left side of the image of statics of economic momentum. The equivalent to social alienation in political momentum is "consumption" alienation in economic momentum expressed by a ratio of satisfied needs to overall needs. Initially, the increase of satisfied needs consolidates social peace. In the area of social peace of the 1st type, on the micro-social level still applies the principle: "the higher the income, the more effective the work." However, the overunning of a certain threshold of "consumption" alienation brings about growing satanization of the class of direct producers: effectiveness of work decreases, absence increases, strikes and outbursts of dissatisfaction become more frequent. In the area of satanization, on the micro-social level the so-far prevailing principle of behaviour transforms. The new principle can be described as: "the higher 
the first kind begins under the conditions of an imbalanced relative prosperity with the goal to protect personal possessions, and a revolution of the second kind is a desperate act aimed to protect against the threat of starvation.

A closer consideration should be given to revolutions of the second kind. Such revolutions correspond with so-called "food riots," a term which appears in historical works. These social disturbances include events, which took place in the North-West England in the years of 1790-1801, and which have been broadly discussed in historical works. ${ }^{320}$ In the second half of the 18th century, the industry was rapidly developing in the region of Lancaster and the Cheshire County. The developing light industry and the swiftly growing towns caused people from all over England to move to this area. This process was accompanied by another process of decreasing the farmland area and by the technological stagnation of agriculture. Shortly, the region lost its ability to self-sustain in food. At the turn of the 18th and the 19th centuries, two additional factors occurred: a decrease of harvest and an economic blockage of England hampering the purchase of food. Simultaneously, wage levels dropped substantially to the level when it became impossible to satisfy the most fundamental needs:

In 1795 wage levels in the cotton industry were in a steady decline which continued until 1802. Wage levels and unemployment were factors in both Rochdale and Saddleworth riots in 1795, but it was in 1799-1800 that such factors became critically important. By 1800 wages were at their lowest ebb for the whole decade while prices had risen by some 300 per cent. [...] The result was great privation and hardship. ${ }^{321}$

A decrease of wage levels and a rapid increase of prices became a threat to biological survival of the lowest layers of the English society. According to Booth, who relies on the epoch's diarists,

the profit, the lower the effectiveness of work." In this area, after exceeding a certain threshold of prosperity, the number of satanized individuals who refuse to subject themselves to any rigours of production grows. This state causes decay of cooperative ties, threatening with future degradation of economy of the given society. The mechanism preventing against a further increase of economic anomie is spread of one of the peculiar attitudes - the pious attitude. Let us remember that an individual by adopting this attitude regardless of the size of the received good, does not become satanized. Thanks to this, grows the number of individuals who voluntarily agree to the rigours of the production process and protect the society against the decay of economic ties.

320 Alan Booth, "Food Riots in the North-West of England 1790-1801," Past and Present, Vol. 71 (1977), pp. 84-108.

321 Booth. "Food Riots," p. 91. 
[b]y the winter of 1800 and the early months of 1801 the poor literally starving. In March 1801 Richard Hodgkinson, agent to Lord Lilford, wrote to his employer: "The poor are absolutely starving for want of both food and clothing. An industrious family in full work cannot earn more than half meat." They were willing to listen to anybody proposing a solution. ${ }^{322}$

A wave of food riots that swept the largest English towns at the turn of the 18th and the 19th centuries brought a solution. The course of these riots was typical. They began with people gathering in public places - squares and streets. Afterwards, someone would initiate plundering homes of wealthy merchants suspected of grain speculation, mills, warehouses for grain exchange, and, less frequently, shops. These acts included breaking glass windows, devastating furniture and equipment. Riots usually ended with a discovery of hidden food supplies. Foot riots were characteristically short-lasting, spontaneous and dynamic.

Perez Zagorin employed the above features to differentiate between a riot, rebellion, and revolution. ${ }^{323}$ It could be assumed that according to Zagorin's classification, a riot corresponds with a revolution of the second kind, which has a historical counterpart in food riots occurring at the turn of the 18th and the 19th centuries in the North-West England.

According to Zagorin, a riot is a spontaneous, unplanned or only roughly outlined outburst. It is a brief social movement that last for the maximum of a few of days. Moreover, the riot participants do not have political or long-distanced goals. Their goals are achievable in a short-term perspective only. A riot is predominantly a manifestation of a spontaneous outburst of anger of the people. The expressive aspect of the riot dominates over its instrumental aspect, namely, the realization of specific goals. ${ }^{324}$ Zagorin recapitulates his reflections in the following way: "Because of these characteristics, riots should be considered as independent phenomena which occur within or separately from revolution and whose connection with the latter is indeteminate." 325

I find it important to comment on the above characteristic in terms of the conceptual categories of $\mathrm{n}-\mathrm{Mhm}$. According to the theory, revolutions have three components: material, institutional and consciousness. Social actions, which disturb the normal relations of class subordination, may have a spontaneous and

322 Booth. "Food Riots," pp. 102-103.

323 Peter Zagorin, "Prolegomena to the Comparative History of Revolution in Early Modern Europe," Comparative Studies in Society and History, No. 2 (1976), pp. 151-174.

324 Zagorin, “Prolegomena," p. 168.

325 Zagorin, “Prolegomena," p. 168. 
a dynamic character. In the analyzed case, they only have a material component. If these actions are structured into state-independent institutions, then a social movement includes an institutional component. If a mass movement is socially self-aware, a revolution receives a consciousness level. ${ }^{326}$

In comparison to a full-blown revolution, riots are social movements lacking the institutional and consciousness components. For this reason, they are simple revolutions. One may distinguish two types of revolutions - starting under the conditions of relative wealth (the first kind) and starting under the conditions of extreme poverty (the second kind) led to biological starvation. Riots belong to the second kind, since they erupt in the situation of extreme dissatisfaction of even the most fundamental needs. As a result, they do not have any long-distance goals and the fundamental needs are relatively easy to satisfy. These two factors - absence of an institutional and a consciousness level, together with a swift shift from the state of extreme poverty to the state of relative wealth (satisfaction of needs) influence the growing satanization of the participants of the riot. This precise element determines dynamism, havoc and the puzzling passion for destruction that characterizes the participants of the revolution of the second kind.

Nonetheless, I disagree with Zagorin who claims that the revolutions of the second kind (riots) are an exact opposite of the revolutions of the first kind (rebellions). The common feature of these movements is the material component that undermines the established relations of class ruling. Moreover, revolutionary movements of both types are generated by the same factor - the state of dissatisfaction of needs: elemental (revolutions of the second kind) or determining the level of prosperity (revolutions of the first kind).

\subsection{Two Types of Revolutions in the Model of an Economic Society}

I would like to argue that the above analysis convincingly justifies the necessity to distinguish two types of revolutions and emphasizes the specifics of the revolution of the second kind. Let us now analyze the amendments made to the model of development of an economic society with the modifications introduced to the statics of economic momentum.

For this reason, let us assume that there is an economic society comprising two social classes: owners and direct producers, isolated from the outside, not organized into institutions of public life and without collective ways of thinking.

326 Grzegorz Tomczak, "Struktura ruchów masowych. Przyczynek do problematyki rewolucji," in: Filozoficzne i metodologiczne podstawy teorii naukowych, eds. Jerzy Brzeziński and Krzysztof Łastowski (Poznań: PWN, 1989), pp. 253-263. 
In this society, the level of productive forces and the number of the branch of production is constant. Moreover, in the economy of this society there occurs simple reproduction. In this model the neighboring aspects of public life, such as politics and culture, do not influence the social processes.

I assume that social processes set out from the state of social peace. However, the class of owners - as result of the mechanism of economic competition - gradually maximizes the surplus product. After introducing the most optimal system of organization of production, the increase of surplus product is possible only by decreasing the variable capital assigned to the class of direct producers. As a result, the gap between the level of needs of direct producers and the size of income assigned to satisfy them grows, which, in turn, brings about the rise of the alienation of labor. And this leads to an intensification of class struggle. Initially, it takes on gentle forms - a decrease of effectiveness of labor, singular riots, etc. - to gradually transform into a mass revolutionary movement of the first kind.

The economic revolution of direct producers may enforce a revision of ownership relations or it may transform into a social confrontation. Let us assume a no loop variant of a social confrontation victorious for the class of owners.

After crushing revolutionary movements in the phase of declassation, owners easily maximize the surplus product at the expense of the variable capital. Under the conditions of growing poverty individuals are forced to compete for income to guarantee survival. Declassation atomizes direct producers and obstructs their ability to organize mass movements. For this reason, the only way to sustain an adequate level of income under the conditions of decreasing variable capital and the disappearance of class resistance is to increase work effectiveness. The attitude of "pathological productiveness" is spread in this phase of social evolution.

However, when the reduction of variable capital reaches a considerable scope, in which it begins to threaten the biological survival of the class of direct producers, the significance of one of the peculiar attitudes - the steadfast attitude increases in a society, in accordance with the anthropological presumptions. The diffusion of the above attitude brings about an outbreak of the revolution of the second kind, serving as a defense mechanism protecting the society against the state of biological starvation. This revolution may enforce an evolution of ownership relations or it may transform again into a social confrontation. Let us assume, correspondingly to the case of the previous revolution, that a social confrontation is victorious for the class of owners.

Contrary to what one might expect, a social confrontation victorious for the owners does not bring about a significant change. The rebelling direct producers may be eliminated, but it is impossible to force the remaining ones to work more effectively under the conditions of a biological starvation. Therefore, after 
the pacification, owners decide to introduce a number of concessions that are supposed to increase the global level of variable capital. A substantial raise of "starvation rations" awakens a revolutionary spirit among direct producers and causes the alienation of labor to re-enter the area of revolutionary disturbances of the 1st kind. Nonetheless, in a long-term, a raise considerable enough to allow direct producers to climb out of the stage of biological starvation, but small enough to maintain the state of declassation, does not bring about beneficial social solutions. This is due to the fact that the mechanism of economic competition leads back to the increase of the alienation of labor, which, in turn, leads back to the revolution of the second kind. Even if the owners manage to crush the protest of the direct producers once more, they will face the same dilemma as before: How to force employees, under the conditions of a biological starvation, to work effectively so that they bring an increased profit to owners?

The only permanent social solution, which increases higher productivity, is an evolution of ownership. A growth of an economic autonomy of direct producers brings about an increase of the effectiveness of their work. As a result, they can work about a higher income and owners can acquire a higher profit. In the phase of the evolution of ownership relations, gradually an increasing number of owners revise ownership relations established between themselves and the direct producers. As soon as the most of production is manufactured within the new ownership relations, an evolutionary transformation of the socio-economic formation occurs. The image of the evolution of an economic society can be demonstrated graphically in the following way:

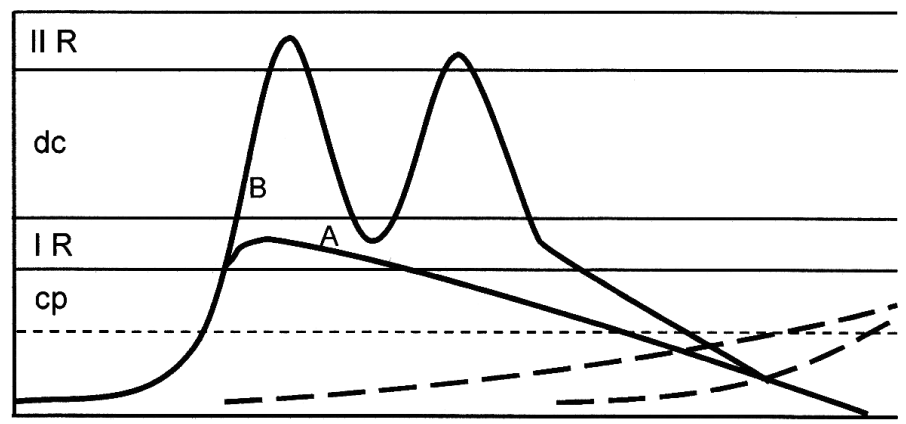

Fig. 16: Two types of revolution in the development of an economic society. Explanations: $c p$ - threshold of class peace; $I R$ - area of a revolution of the 1st kind; $d c$ - threshold of declassation; II $R$ - area of a revolution of the 2nd kind; $A$ - variant of a development ending with a compromise - revision of ownership relations; $B$ - confrontational variant of a social evolution; solid line - alienation of labor; dotted line - evolution of ownership relations. 
I would like to conclude the present chapter with an overview of the amendments introduced to the standard model of an economic society. The model assumed the following developmental lines:

(1) the growth of the alienation of labor - lost economic revolution - evolution of ownership relations;

(2) the growth of the alienation of labor - revolution won by a working class economic loop concluded with a lost economic revolution - evolution of ownership relations;

(3) the growth of the alienation of labor - revolution won by owners - decrease of the effectiveness of labor enforcing an evolution of ownership relations.

An evolution of an economic society founded on the assumptions of a nonrationalistic model of man increases the number of possible variants of a social development. Most importantly, there is a shift in the transformation of ownership relations. According to the standard model, the revision of ownership is an inherent consequence of an economic revolution (identified with the revolution of the first kind). I will present the possible variants of the social development in the modified model using the following scheme, in order not to overcomplicate the structure of the argument:

(1) $A L+1 R E V^{0}+E V O L$

(2) $A L+1 R E V^{+}+A L+1 R E V^{0}+E V O L$

(3) $A L+1 R E V^{+}+A L+1 R E V^{-}+D E C L+2 R E V^{0}+E V O L$

(4) $A L+1 R E V^{+}+A L+1 R E V^{-}+D E C L+2 R E V^{+}+A L+1 R E V+E V O L$

(5) $A L+1 R E V^{+}+A L+1 R E V^{-}+D E C L+2 R E V^{-}+E V O L$

(6) $A L+1 R E V^{-}+D E C L+2 R E V^{0}+E V O L$

(7) $A L+1 R E V^{-}+D E C L+1 R E V^{+}+A L+1 R E V^{0}+E V O L$

(8) $A L+1 R E V^{-}+D E C L+2 R E V^{-}+E V O L$

Key: $A L$ - phase of a growing alienation of labor; $1 R E V^{0}$ - revolution of the first kind ended with a class compromise: an evolution of ownership relations; $1 R E V^{-}$- revolution of the first kind concluded with a loss of the class of direct producers; $1 R E V^{+}$- revolution of the first kind concluded with a victory of the class of direct producers bringing about a temporary decrease of the alienation of labor; DEC - declassation bringing about disappearance of class struggle; $2 R E V^{0}$ - revolution of the second kind concluded with a class compromise an evolution of ownership relations; $2 R E V^{-}$- revolution of the second kind concluded with a loss of the class of direct producers; $2 R E V^{+}$- revolution of the second kind concluded with a victory of the class of direct producers and 
bringing about a temporary decrease of the alienation of labor; EVOL - evolution of ownership relations.

For this reason, even if we exclude the chance of additional loops, the economic development of a given society has at least eight possible developmental lines. 



\section{Part IV The Conceptualization of the Distinctiveness of Central Europe}





\section{Models of the Source of a Cascade}

\section{Model II: An Economic Society with a Surplus of Manpower}

\subsection{Assumptions of the Model}

I shall now investigate the impact of surplus of manpower in the development of an economic society. In model II of an economic society, the idealizing assumption concerning balance of the labor market is substituted with another assumption - that a society under study has a workforce surplus. The level of surplus of manpower is expressed with the difference between the population of a given society, or, more precisely, the number of persons in the productive age, and the optimal level of employment. Additionally, an assumption is made that the level of workforce surplus remains constant during the developmental process of a society. The remaining idealizing assumptions remain unchanged, in comparison to the modified basic model of an economic society. This model assumes the existence of only two social classes: owners and direct producers. Moreover, it assumes that these social groups are not organized into institutions and that the social processes under study are not influenced by socio-economic doctrines. The simplifying assumptions of this model additionally reduce the social influence of other social classes: not only rulers and citizens but also priests and believers. The society under investigation is isolated from the outside. For this reason, its internal social processes cannot be explained with the impact of neighboring societies. The subsequent set of idealizing assumptions already has an economic character. The adopted assumptions state the following: productive forces in the society under study remain at a constant level (technological advancement does not exist), the number of the branches of production is stable and the accumulation level equals zero (simple reproduction takes place).

\subsection{Social Resistance of the Unemployed}

A society characterized by a labor surplus has two social categories of a working class: the employed and the unemployed direct producers. I will begin with defining static regularities of a class struggle of the unemployed layer of direct producers. Afterwards, I will determine the dependencies between the level of alienation of labor and the social ties bonding direct producers and owners, in order to determine a combined influence exerted of both layers of the class of direct producers on the statics of economic momentum. 
Initially, in a very brief and intuitive way, I will attempt to conceptualize the status of the unemployed segment of the class of direct producers. In every economic structure there are two distinguishable types of the relations of production - typical and untypical for a given formation. In a class society, under my investigation, typical relations of production include ones, which: assume a class division in a social process of production, the majority of production is manufactured within them, they constitute the source of income for the greater part of the society. Untypical relations of production include those which do not satisfy some of the following postulates: they do not generate a class division, do not constitute a visible minority in an economic structure of a given society and they ensure a substantially lower income capable of satisfying only the most elemental needs. For instance, untypical relations of production are the residual elements from previous "non-antagonistic" social formations. The distinguished forms of economy usually include such activities, as hoarding, hunting, fishing, etc. For this reason, to be without a job means to be unemployed within typical economic relations of a given society. Under the adopted description of untypical relations of production, by undertaking any activities within them producers bring about poverty and dissatisfaction of the greater number of needs. Being unemployed within typical relations of production equals declassation.

Absence of fixed income and presence of problems with finding permanent employment prevent direct producers from satisfying the majority of their basic economic needs. On the other hand, poverty brings about a situation, in which the unemployed are forced to compete between themselves to acquire the most elemental economic goods. Economic poverty crushes autonomous interpersonal ties between the unemployed and paralyzes their ability to organize collective incidences. For this reason, the unemployed, subjected to the process of declassation, are not a revolutionary category. Therefore, in static relations between the level of alienation of labor and the level of class struggle there is no area of the revolutionary disturbances of the first kind.

However, when the state of dissatisfaction of economic needs begins to endanger biological existence, the social category of the unemployed turns into a rebellious element. Following from this, the threat of biological starvation revolutionizes them. The peculiarity of this social category rests on having a single revolutionary area - the area of a revolution of the second kind. The above-discussed relations can be demonstrated graphically in the following way: 


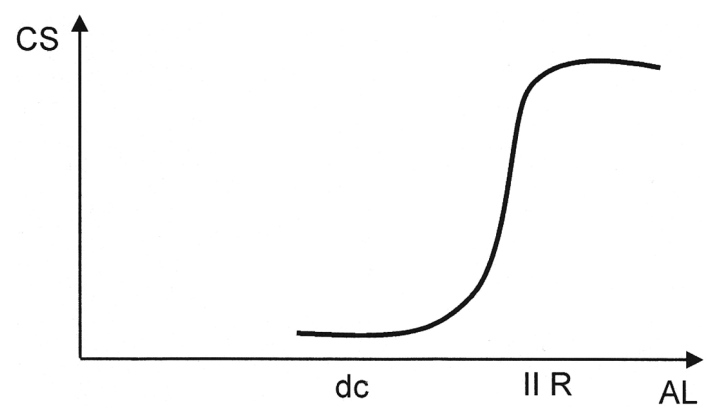

Fig. 17: Social resistance of the unemployed. Explanations: CS - level of economic class struggle; AL - alienation of labor; dc - interval of declassation; II R - interval of a revolution of the second kind. The above key will be used hereinafter.

\subsection{Social Resistance of the Employed}

The static image of dependencies between the level of alienation of labor and the level of social conflict between owners and direct producers includes the following areas: class peace, revolution of the first kind, economic declassation and revolution of the second kind. In the area of class peace, the greater part of needs of direct producers is satisfied; hence the percentage of rebelling individuals is small. The advancement of alienation of labor brings about an increase of social resistance of direct producers. Their resistance becomes widespread with the growth of the alienation of labor. In the area of the revolution of the first kind, class struggle gains a common character. However, a further growth of the alienation of labor atomizes the working class, by taking away its ability to organize mass incidents, due to the fact that in the area of declassation direct producers have to compete between themselves to acquire means to ensure the most essential material goods.

However, a revolution of the second kind outbreaks when the alienation of labor increases to an extreme level, so that it endangers biological survival of direct producers. Then, the mechanism of revolutionary struggle turns into a defense mechanism, which protects the society against the threat of hunger. The above-discussed image of social dependencies can be demonstrated graphically in the following way: 


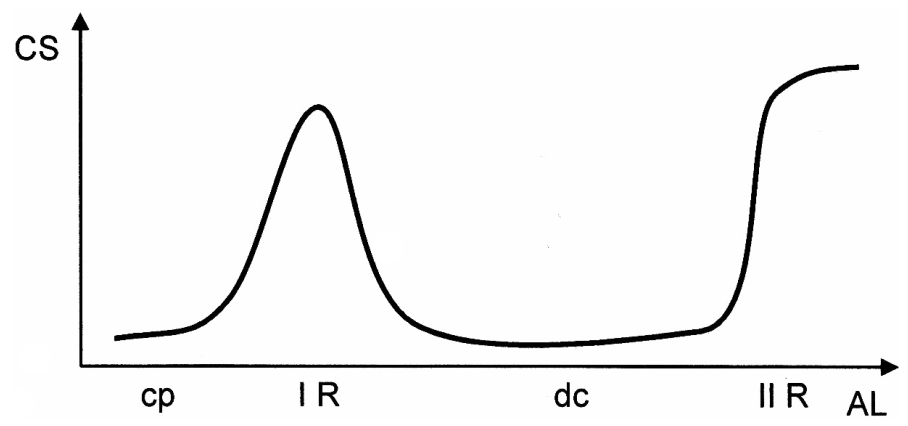

Fig. 18: The dependency of the intensity of class struggle on the alienation of labor of the employed strata of the class of direct producers. Explanations: $C S$ - economic class struggle, $A L$ - alienation of labor, $c p$ - interval of class peace; $I R$ - interval of a revolution of the first kind; $\mathrm{dc}$ - interval of declassation; II $R$ - interval of revolution of the second type.

\subsection{The Image of Social Resistance of Direct Producers}

Let us now determine a comprehensive image of the statics of economic momentum, which includes the combined influence of both layers of the class of direct producers. The presence of the unemployed brings about a modification to the mechanism of class struggle. Under the conditions of excess workforce, owners can easily replace a rebelling employee with an unemployed person. The presence of the "reserve army of employees" eager to take up work with a lower income allows a typical owner to decrease variable capital of the employed direct producers, without risking social resistance. This brings about a situation in which a class of direct producers becomes revolutionized only when the gap between their needs and incomes becomes larger than in standard society. Therefore, the impact of the "reserve army of employees" obstructs the mechanism of class struggle, by shifting the first area of revolutionary disturbances.

Additionally, the social category of the unemployed transforms the very course of a class struggle. The threat of losing a job or of deteriorating work conditions, etc. paralyzes singular acts of resistance. Only widespread resistance is relatively safe. Thus, the shift from the area of class peace to the area of the revolution of the first kind is sudden and deprived of an intermediate stage of a gradual raise of class struggle. The above phenomenon of "prerevolutionary silence" does not permanently crush the ability to resist, but it corrects the course of resistance. As distinct from a complete reduction of social conflict, the above amendment results from a rationalistic assumption that, various proportions between the 
employed and the unemployed notwithstanding, the social category of the employed always dominates the unemployed. For this reason, the influence of the "reserve army of employees" on the statics of economic momentum will always be secondary and will constitute a mere modification of the basic mechanisms.

To recapitulate the above analysis: surplus workforce shifts the first revolutionary image by modifying the curve of class struggle with the effect of "prerevolutionary silence."

Nonetheless, the growth of the alienation of labor finally brings about a revolutionary disturbances of the first kind. Yet, in case of a society with a surplus of manpower, the increase of alienation must be higher, in comparison to a society with a balanced labor market. The employed segment of the class of direct producers participates in a revolution of the first kind, whereas the declassed layer of the unemployed remains passive. However, the passive attitude of this social layer of the unemployed influences the course of social events happening in the revolutionary area. Owners may put the "reserve army of employees" into service to suppress the direct producers' protests. They simply have to replace rebelling direct producers with unemployed ones. Under the conditions of overcompetition at a labor market it is easy to find a replacement for a rebelling employee, therefore declassation of direct producers takes place at a lower level of alienation of labor, in comparison to standard society. A surplus of manpower, by facilitating the process of declassation of direct producers, produces an effect of "post-revolutionary silence."

In the area of declassation, the majority of economic needs of direct producers is not satisfied, but the global level of variable capital still ensures satisfaction of needs, which determine the threshold of biological existence. In the discussed area of social relations the level of social conflict is low, because poverty obstructs the ability for mass incidents, by disrupting autonomous interpersonal ties. Increased exploitation of the employed segment of the class of direct producers simultaneously influences the situation of the unemployed layer. The raise of exploitation brings a growing number of direct producers to supplement income with work performed within untypical relations of production. In the area of class peace, the income acquired within untypical relations of production is too low, to be of interest to the employed wealthier segment of the class of direct producers. However, in the area of declassation activities, such as "picking up berries," gain significance within the general structure of income. Nonetheless, according to the adopted characteristics of untypical relations of production, activities performed within this economic sector cannot serve as the source of income for the entire class of direct producers. The higher the alienation of labor, the quicker the increase of the number of the employed, who begin to supplement their income 
with jobs performed within this economic sector. However, as a result the situation of the unemployed deteriorates, since the non-class economic sector has been their only source of income. Thus, in the area of declassation the income of the entire class of direct producers, and not of only one of its subcategories, decreases. Revolutionary protests of the second kind take place when the level of alienation of labor reaches a threshold of biological threat. This time, the entire class of direct producers participates in the events. The effect of "prerevolutionary silence" modifies the course of the revolution. It is a rapid shift from the area of declassation to the area of a revolution of the second kind.

Let us now recapitulate amendments introduced to the statics of economic momentum by the presence of surplus workforce:

(1) The above factor shifts the area of a revolution of the first kind.

(2) Surplus manpower modifies the course of class struggle by the effect of "prerevolutionary silence." This phenomenon consists in a reduction of the preliminary class struggle and a rapid shift from the area of class peace to the area of a revolution of the first kind.

(3) Presence of the "reserve army of employees" brings about the effect of "postrevolutionary silence" consisting in a rapid shift from the area of a revolution of the first kind to the area of declassation. This effect results from the presence of the "reserve army of employees" facilitating a declassation of direct producers.

(4) A revolution of the second kind takes on a widespread form, because it engages both layers of the working class. The course of the revolutionary incidents is modified by the effect of "prerevolutionary silence."

The image of social dependencies outlines above can be demonstrated graphically in the following way:

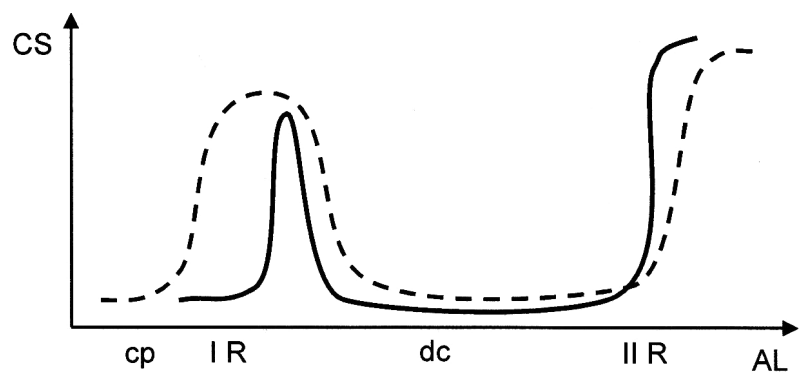

Fig. 19: The dependency of the intensity of class struggle on the alienation of labor in a society with a surplus of manpower. Explanations: solid line - class struggle in society with a surplus of manpower; dotted line - class struggle in a standard economic society. 


\subsection{Development of an Economic Society with a Surplus of Manpower}

Surplus workforce brings about an evolution of an economic society. For this reason, let us now investigate the social development of this type of society. Let us assume that in the starting point of the social processes under study, class peace prevails. However, under the influence of the mechanisms of economic competition, a typical owner maximizes his/her profit by reducing individual variable capital granted to direct producers. Owners apply various strategies to appropriate surplus product. The first distinguishable group includes owners who grant their producers a significant, above-average individual variable capital. The second group includes those who appropriate the above-average surplus product. Finally, there is a group of owners, who apply moderate systems of appropriation - more rigorous then the owners from the first group and less restrictive than the owners from the second group. In the society under investigation, for obvious reasons, owners who apply the least rigorous forms of appropriation of surplus product lose the most. Moreover, owners who introduce moderate systems of division of the newly manufactured product in their productive units also lose. As I have already stated, surplus manpower present on the market obstructs the mechanism of social resistance, hence owners who introduce the most rigorous forms of appropriation of surplus product, acquire the highest profit. This state of affairs, let us add, differs from a situation of standard society, where the "moderates" achieve highest profit.

After a certain time, under the mechanisms of learning, the remaining owners introduce stricter forms of appropriation of surplus product. If some of them postpone this change for some reason, they will be eliminated from the class of owners. In this way, the global value of variable capital granted to the class of direct producers decreases. However, an increase of the alienation of labor does not bring about an intensification of class struggle. The latter is influenced by the state of eagerness of the unemployed direct producers to take up work providing a lower income. The presence of the unemployed social layer obstructs the mechanisms of social resistance of the employed segment of the working class.

An increase of the alienation of labor will finally bring about an outbreak of a revolution of the first kind. In the case of the investigated society, an economic revolution erupts after a long time, suddenly, without an intermediate stadium of gradually increasing class struggle. This course is influenced by the effect of "prerevolutionary silence," which reduces the intensity of social conflict in an intermediate stadium of a class struggle, between the area of class peace and the area of a revolution of the first kind. 
In model I of an economic society, a revolution of direct producers may conclude with a class compromise, or it may alternatively transform into a social confrontation. The adopted level of idealization impedes an accurate estimation of the probability of the above social variants. In model II of an economic society, differently, the presence of the unemployed increases the probability of a social confrontation. Owners pursue a confrontation, since they can use the unemployed to suppress the riots of direct producers. Let us remember that only a part of the class of direct producers participates in this revolution. The unemployed, or declassed direct producers (in line with the adopted assumptions), remain passive. Under these conditions, owners replace the rebelling direct producers with randomly chosen unemployed ones. In this way, the class of owners brings social peace without the necessity to introduce social concessions.

A revolution victorious for the class of owners is followed by further reductions of the variable capital. The state of poverty disrupts a collective solidarity, since direct producers are forced to compete between themselves to acquire the most essential economic goods. The disappearance of class struggle allows owners to introduce gradually growing reductions of the variable capital granted to direct producers. A successive decrease of the global value of the variable capital leads to a situation, in which direct producers begin to supplement their income with jobs undertaken under the non-antagonistic relations of production, which have, so far, constituted the sole source of income for the unemployed. Previously, the employed segment of the class of direct producers perceived jobs belonging to the secondary economic sector as uneconomical, because they acquired higher income from jobs performed within the key economic sector. However, in this phase of social development, jobs, such as "picking up berries," become a more significant source of income. "More significant" because, according to the adopted assumptions, the non-antagonistic relations of production occupy a minor position within the general economic structure and cannot constitute the source of income for the entire class of direct producers. If a growing number of direct producers take up an array of activities belonging to the secondary economic sector, the already bad situation of the unemployed deteriorates even more. An increase of the alienation of labor in the key economic sector causes a decrease of income of the entire class of direct producers. The more the exploitation advances, the larger the number of direct producers searching for sources of income in the secondary economic sector. The unemployed, in contrast to the employed in the key economic sector, are forced to undertake jobs under the relations for production untypical for a given economy; therefore this social layer is the first to be endangered with starvation. The uneven growth of the alienation of labor - swift in case of the unemployed 
and slower in case of the employed - brings the social layer of the unemployed to become a revolutionary category more promptly. This time, the presence of the social layer of the unemployed accelerates an outbreak of a revolution of the second kind engaging both subcategories of the class of direct producers. Hence, surplus workforce accelerates an outbreak of a revolution of the second kind.

The above-mentioned revolution retransforms into a social confrontation. The class of owners achieves a victory over the rebellious direct producers, but it is a Pyrrhic victory. Even if owners physically eliminate the rebelling direct producers, they will fail to bring the remaining direct producers to work more effectively, due to the threat of a social collapse.

The situation may be improved by employing the unemployed. However, in a long-term perspective, it will bring about a negligible result, because the effectiveness of labor of the direct producers who belong to the category, which has remained in a situation of extreme poverty for a long time, is as low, as the effectiveness of the employed layer of the class of direct producers. In this phase of social development, the decision to bring the unemployed to play will only postpone an introduction of a permanent solution. Also a decrease of the level of appropriation of surplus product does not provide a permanent solution. The process of granting too large income to direct producers causes the social system to enter the first area of a social disturbance. The process of granting too small income brings the alienation of labor to re-enter the second area of revolutionary disturbance, due to the impact of an economic competition. In a long-term perspective, a permanent solution is brought by a revision of ownership tying direct producers and owners. A consequence of a revision of ownership relations is an increase of production autonomy of direct producers, which, in turn, increases their effectiveness of labor. Employees receive higher income and owners acquire higher profits on account of the increased production. An increase of income of direct producers simultaneously brings this social group to withdraw from taking up jobs belonging to the secondary economic sector. This, in turn, improves the situation of the unemployed, who remain in the state of declassation. Nonetheless, this situation does not bring about a shift to a new socio-economic formation, which appears when the greater part of production is manufactured under new ownership. The above image of the evolution of an economic society with surplus manpower is demonstrated graphically in the Figure 20 (page 248).

Let us now recapitulate amendments introduced to an evolution of an economic society by the factor of surplus workforce:

(1) In the phase of the growing alienation of labor the factor of surplus manpower obstructs the mechanism of class struggle. For this reason, this phase of social development is prolonged. 


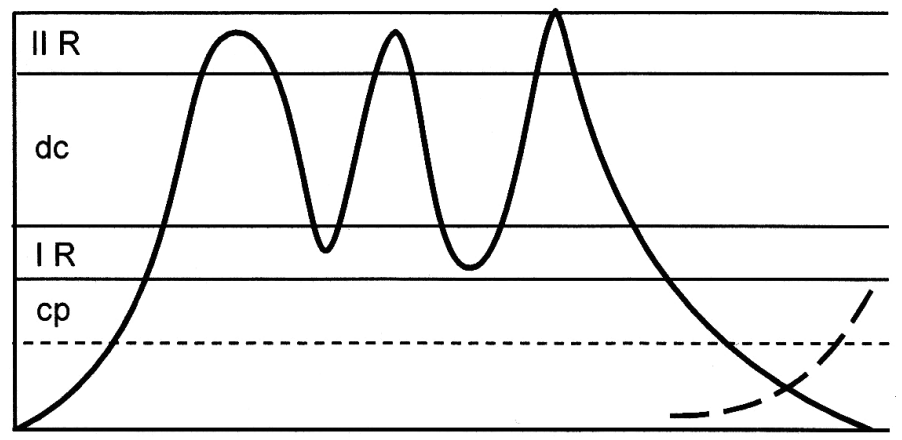

Fig. 20: Development of an economic society with surplus workforce. Explanations: $c p$ - threshold of class peace; $I R$ - area of a revolution of the first kind; $d c$ - threshold of declassation; II $R$ - area of a revolution of the second kind; solid line - alienation of labor; dotted line - evolution of ownership. The above key will be used hereinafter.

(2) The effect of "prerevolutionary silence" brings about a sudden outbreak of an economic revolution; a shift from the area of class peace to the first area of revolutionary disturbance occurs without the intermediate stadium of a gradual increase of class struggle.

(3) The factor of surplus workforce causes a revolution of the first kind to transform into a confrontation; during the confrontation, the effect of "postrevolutionary silence" facilitates a declassation of the direct producers by the class of owners.

(4) In the phase of declassation the presence of the "reserve army of employees" accelerates an outbreak of a revolution of the second kind.

(5) Revolution of the second kind also transforms into a confrontation; however it enforces a revision of ownership regardless the outcome.

(6) In the phase of the evolution of ownership also the economic situation of the social layer of the unemployed is improved - they cease to be a revolutionary category causing revolutionary disturbances of the second kind, by returning to the state of declassation of the first kind.

\section{Model III: An Economic Society with a Shortage of Manpower}

\subsection{Assumptions of the Model}

In the present chapter, I would like to investigate the influence of the shortage of manpower on the evolution of a purely economic society by developing a 
subsequent theoretical model. In this way, I shall determine the key regularities of an economic development. The basic model of an economic society in terms of non-Marxian historical materialism is based on a tacitly adopted assumption that owners employ a sufficient number of workers and that every direct producer is employed. I will now substitute this assumption with a different one, according to which there is insufficient workforce with respect to the economy's productive potential. The level of deficiency of manpower is determined by the difference between the optimal level of employment (number of workplaces) and a number of population in productive age. Moreover, I assume that the level of a shortage of manpower is constant; it does not decrease or increase in the course of the development of an economic society. Other idealizing assumptions of the basic model of an economic society remain unchanged.

\subsection{The Shortage of Manpower versus the Social Resistance}

Let us now turn to an investigation of the influence of the deficiency of workforce on the statics of economic momentum in order to follow up with a determination of the impact of this factor on the development of an economic society. Let us recall that in the basic model of an economic society, the social relation between direct producers and owners depend on the level of alienation of labor. And the latter is defined by the difference between the level of needs expressed by direct producers at a given time in a given society, and the revenue that can be assigned to satisfy them. If the income acquired by direct producers is sufficient to satisfy the greater part of their needs, then the alienation of labor is low, and social peace prevails in the relations between direct producers and owners. Social peace prevails also when the alienation of labor is high. Under these conditions, poverty disrupts interpersonal solidarity and obstructs the ability of direct producers to undertake mass resistance. An economic revolution takes place when the level of alienation of labor is average - when it becomes problematic, but it does not yet compromise the chances for mass incidents. Social disturbances occur also when the alienation of labor takes extreme values endangering biological existence of direct producers.

To ensure a continuance of production and, in consequence, regular acquisition of profit from an economic activity, one should employ an optimal number of workers. The shortage of manpower causes a part of productive potential, at disposal of a typical owner, to be not in use. Thus, the factor of deficit workforce, increases the demand of owners on direct producers. A typical owner, in order to 
ensure stability and an optimal level of employment in his/her production unit, grants a higher income to direct producers, in comparison to standard society. A competition between owners aiming to employ the highest possible number of workers has a global effect of an increase of employee income. Under the conditions of deficiency of workforce, the threat of migration of direct producers - abandoning their current workplace and searching for a new one bringing a higher income - is one of the basic forms of class struggle, which forces owners to grant economic concessions.

The two above-mentioned phenomena occurring in the model of an economic society under study, namely, first, a competition between owners aiming to employ the highest possible number of direct producers, which brings about higher income, in comparison to standard conditions and, second, a relative easiness to change workplace, modify static dependencies of class struggle. The effectiveness of social resistance manifested by migration brings about a situation in which class struggle begins to grow already in the lower state of alienation of labor - as distinct from a standard economic society characterized by a balanced labor market. Moreover, under the conditions of shortage of workforce, direct producers easily enforce an introduction of economic concessions. Therefore, an increased effectiveness of employee resistance leads to a situation where even insignificant decrease in income brings about individual escapes and migrations of direct producers to owners offering higher income. The higher the alienation of labor, the more widespread the employee migrations. A further growth of the alienation of labor causes the scope of migration of workforce to grow to such a substantial size, that there appears a threat of a meltdown of a production order. Owners' attempts to prevent escapes of direct producers transform mass migrations into open social disturbances. All of the above takes place - let us repeat - already in the lower stages of alienation of labor in comparison to standard society. Hence, deficit of manpower causes a shift of the area of revolutionary disturbances toward the left. The scope of this shift depends on the scope of shortage of workforce.

Additionally, the shortage of manpower influences the course of class struggle. Escapes and migrations may have an individual character, hence in the area between class peace and revolutionary disturbances, the percentage of the revolting persons grows substantially. On account of the above, the shift from one area to another occurs in a smoother and more gradual way, in comparison to a standard economic society. The factor under analysis impedes a declassation of direct producers by increasing the number of participants of revolutionary disturbances. For this reason, the first area of revolutionary disturbances is prolonged. It occurs as soon as in the lower stages of alienation of labor, in 
comparison to standard society, and it disappears under the conditions of a higher level of alienation of labor.

A competition between owners for manpower additionally hinders the decrease of the alienation of labor in the area of declassation. In this area the level of exploitation is milder, in comparison to a standard economic society; thus, the demobilizing impact of poverty on a working class also decreases. For this reason, the level of social conflict, however significantly reduced, does not disappear entirely. This results from a competition between owners for workforce, which reduces the drop of income of direct producers in the area of declassation.

Moreover, the shortage of manpower affects the area of the second revolution. An increase of the alienation of labor poses a threat to the biological existence of direct producers and brings about a repeated increase of social resistance manifested with mass employee migrations. When owners attempt to prevent migration, which poses a threat to the production order, it transforms into revolutionary disturbances. Under the conditions of deficiency of workforce, an increase of effectiveness of social resistance causes the areas of revolutions of the first and the second kind to occur with a lower level of the alienation of labor, in comparison to a standard economic society. Furthermore, a shift from the area of declassation to the area of a revolution of the second kind has a more gradual character (in comparison to the statics of a standard economic society). As a result of the impact of the deficit workforce, the area of the revolution of the second kind also shifts toward the left. The dependencies discussed above can be demonstrated graphically in the following way:

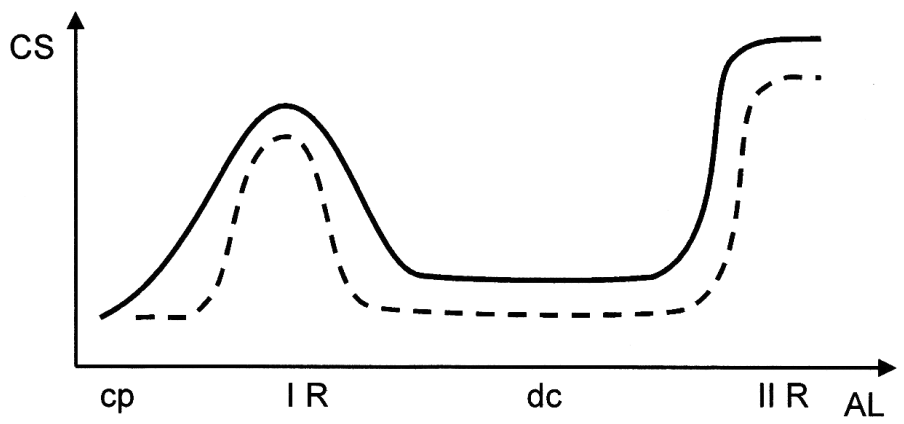

Fig. 21: Dependency between the intensity of economic class struggle and the alienation of labor in a society with a shortage of manpower. Explanations: solid line - economic class struggle in a society with a shortage of manpower; dotted line economic class struggle in a standard economic society. 
To conclude this part of my analysis, I would like to recapitulate the modifications introduced to the statics of economic momentum by the deficiency of manpower:

(1) Area of a revolution of the first kind - in comparison to standard society shifts toward the left; this kind of revolution occurs already when the level of alienation of labor is lower, in comparison to standard society.

(2) A shift from the area of class peace to the first revolutionary area is smoother, since the percentage of the revolting individuals grows significantly in the intermediate area of a class conflict - between the areas of class peace and a revolution of the first kind.

(3) A revolution of the first kind occurs already with lower level of alienation of labor, in comparison to a society with a balanced labor market; and the revolutionary disturbances disappear with higher level of alienation of labor. This revolution is also more widespread.

(4) Within the area of declassation, the level of conflict is reduced, but it does not disappear entirely; a shift from the area of declassation to the area of a revolution of the second kind is also gradual.

(5) The shortage of manpower causes a revolution of the second kind to outbreak with a lower alienation of labor.

\subsection{Development of an Economic Society with a Shortage of Manpower}

Let us now investigate an impact of the shortage of manpower on a development of an economic society. It is assumed that, at the starting point, every owner has an equally small number of employees - hence, they have an unused part of economic potential at their disposal. Various owners may apply various systems of appropriation of surplus product and various strategies of division of the newly manufactured product. There are three distinguishable groups of owners. The first group includes owners who appropriate the above-average surplus product. Direct producers react with widespread escapes and leaving work, which takes on such an enormous size that it forces owners to mitigate the rules of division of newly manufactured product. If an owner refuses to do so, for some reason, he/ she will transform into an individual owner using only his/her own workforce. The second group of owners grants their employees substantial variable capital higher than above-average. As a result, those owners may employ additional workforce and ensure an optimal level of employment, by exploiting a higher number of direct producers to a lesser degree. The third group of owners applies 
average forms of appropriation of the individual surplus product. They do not lose direct producers, but they also do not acquire new ones. In an economic society with deficit workforce, owners ensuring an optimal level of employment, namely, those employing the gentlest systems of appropriation of surplus product, reach the highest level of profit. This state of affairs, let us emphasize, varies from the situation of standard society, where "moderates" using moderate forms of appropriation of surplus product acquire highest profits, and is contrary to a situation of society with surplus workforce, where the most "severe" owners who employ the above-average forms of appropriation acquire highest profits. Under the mechanism of learning, owners from the first and the third group will be forced to accordingly mitigate the way of division of newly manufactured product, or they will lose their direct producers and transform into individual owners.

A competition between owners for workforce has a global effect, namely a decrease of the alienation of labor. The impact of an economic competition brings about a development of three layers of owners. The first layer includes owners who grant highest income to direct producers and achieve an optimal number of employees. The second layer includes owners who grant average income to direct producers. This category of owners employs an insufficient number of employees. Finally, there is the third category of owners, which includes those who grant the lowest income to direct producers. As a result, they lose direct producers who migrate to the first or the second layer of the class of owners. Theses owners transform into individual owners who use only their own workforce.

When the greater part of an economic production is manufactured in production units belonging to owners who have an optimal number of direct producers, then rules of increasing profit to maximum retransform. These owners employ an optimal number of direct producers, hence an increase of profit to maximum cannot any longer be based on a further increase of the number of employees, but on an introduction of increasingly more rigorous systems of division of newly manufactured product. Increased exploitation does not result with immediate migration of direct producers. A number of factors decide if an employee stays in his/her current workplace: long-lastingness of class peace, risk accompanying a transfer, etc. Nonetheless, with the growing alienation of labor, the number of cases of escape of direct producers grows. Hence, a boost of the alienation of labor in a global scale brings about a subsequent intensification of migration of direct producers to owners offering higher income. Under the conditions of a purely economic society - without the class of disposers of centralized means of coercion - owners are unable to effectively break off the migration stream of direct producers. Their only strategy is to once more mitigate 
the system of appropriation of surplus product. In this stadium of social development, the mechanism of increasing profit to maximum is again a competition between owners for acquiring the highest number of direct producers. On a social plane, this competition brings about a decrease of the alienation of labor to the threshold of a class struggle. The above process persists until once more a group is created within the class of owners, which has an optimal number of workforces. Then, again, the rules of increasing profit to maximum retransform, consisting in a reduction of the income of direct producers, which will, in turn, cause another intensification of migration after a certain time. Therefore, periodically repeated migrations of direct producers, forcing owners to grant economic concessions, are a "soft" form of class struggle.

To put in more general terms, in this phase of social development, the alienation of labor oscillates around the threshold of class peace. The growth of the alienation of labor above the threshold of class peace brings about an increased migration; and migrations, in turn, enforce the alienation of labor to drop below the threshold of class peace. The oscillation of the alienation of labor around the threshold of class peace does not, however, guarantee a stability of a labor market. Economic competition enforces periodic stadia of mitigation and the escalation of exploitation. The only solution guaranteeing stabilization of a labor market is a revision of ownership. Hence, after a repeated cycle of decreasing and increasing the alienation of labor in a society, there appear owners who reduce exploitation and, most importantly, transform the rules of ownership. These owners give up part of their prerogatives in the field of decision-making concerning the production process. This brings an increase of autonomy of direct producers in the production process, which, in turn, leads to higher efficiency. An increase of productivity ensures higher profit for owners and higher income for employees. In the phase of an evolution of ownership, the shortage of manpower accelerates a formation of new rules of ownership, because their introduction ensures higher productivity of direct producers and, most significantly, an optimal level of employment. The phase of an evolution of ownership is shortened, in comparison with a phase of transformation of ownership in a standard economic society. Noteworthy, this stadium of social development is not brought about under the pressure of "hard" forms of class struggle, namely a revolution, but under the impact of its "soft" forms - migration of direct producers.

Let us now recapitulate amendments introduced to the development of an economic society by the presence of shortage of manpower:

(1) The factor under analysis causes a situation when already in the initial phase of the development of an economic society appears a decrease of the 
alienation of labor. The threat of employees' escapes serves as the mechanism enforcing concessions. Under the conditions of shortage of manpower, an increase of profit to maximum does not enlarge surplus product, but it optimizes employment.

(2) In case of above-average mitigation of exploitation, the phase of the growing alienation of labor is significantly modified. In this stadium of development, the alienation of labor oscillates around the threshold of class peace. The source of revision of ownership is not a revolutionary resistance of direct producers, but an assurance of stabilization of workforce. In this phase of development a non-revolutionary transformation of ownership takes place.

(3) The phase of evolution of ownership relations, in comparison to an evolution of ownership relations in a standard economic society, has a shortened course. Owners who revise ownership simultaneously bring about an increase of productiveness of direct producers and, in consequence, an increase of own profit and of the level of employment in their own production units. As a result, their advantage over owners maintaining traditional ownership relations grows.

The development of an economic society can be demonstrated graphically in the following way:

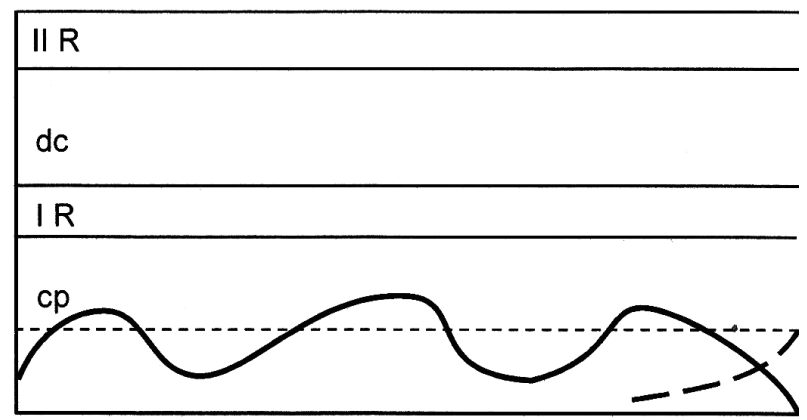

Fig. 22: Evolution of an economic society with a shortage of manpower.

\subsection{A Scope of the Historical Application of Models}

Let us now discuss the issue of historical application of the developed models of the source of a cascade of European distinctiveness. Most importantly, I would like to state that the factors of surplus and shortage of manpower should be 
introduced to model IV of non-Marxian historical materialism, which is an approximation of the development of feudal society. This has not been done, since the model of feudalism in n-Mhm explains the development of CentralEuropean societies only to a limited degree. Moreover, the range of amendments would have been inversely proportional to the level of complication of the structure of the argument.

The principal thesis of model II is that a surplus of workforce brings about a deterioration of an economic situation of direct producers and an escalation of social conflict. This model refers only to a part of the history of Western European societies - covering a period between the second half of the 13th century until the first half of the 14th century. In this period, Western Europe was facing overpopulation (or, in our terminology, the problem of a surplus of workforce) with respect to available arable land (the phenomenon of exhaustion of cultivated land was also present). Social consequences of a surplus of workforce were weakened by the factor of colonization of new land, which also spread over CentralEuropean countries between the 13th and the 14th centuries. However, the 2nd model, adopting an assumption concerning isolation of a society under investigation, omits the influence of other societies, including migrations between societies, which modify the dependencies formulated in the model to a significant degree. Peasant migrations spreading over the less-populated Central-European countries were unable to defuse the problem of surplus workforce entirely. Signs of deteriorating living conditions of peasant masses included repeated famines and a decreasing resistance of the society to epidemics and diseases. The plague, which outburst in the middle of the 14th century, decreased the population and simultaneously eliminated the problem of relative overpopulation. Western Europe was facing a relative shortage of workforce in the 2 nd half of the 14th century and in the beginning of the 15th century.

On the other hand, the principal thesis of model III states that the shortage of manpower brings about an improvement to the situation of direct producers and contributes to the mitigation of a social conflict. However, a historical evolution of the Central-European societies proves the developed model to have a limited potency for explication. In fact, it is capable of explaining the history of Central-European societies between the 12th and the 15th centuries. Then, the Central-European countries experienced a reorganization of feudal relations under the name German Law, which substantially improved the situation of the peasantry. According to historians, one of the reasons for the reorganization was the shortage of workforce, which constituted a significant barrier that prevented an increase of income. However, the further evolution of the Central-European societies contradicts the developmental trends assumed by the above model. 
The emergence and development of an institutional framework of manorial-serf economy were social conditions of an increase of the alienation of labor, not its decrease. This course of development of Central Europe was determined by a number of co-occurring factors, which formed a cascade of European distinctiveness, which dominated the impact of the principal social mechanisms enforcing a decrease of the alienation of labor. The following chapter is devoted to subjecting the influence of these factors to an empirical analysis. 



\section{The Genesis of European Differentiation}

\section{On the Peculiarities of Feudalism in Central Europe}

European feudalism came to existence in three separate cultural-geographic zones. ${ }^{327}$ In the first zone, covering Italy, southern France and Spain, which was dominated by the ancient social system, feudalism developed in the course of an internal evolution of slave relations of production. In the second zone, covering the terrains of central and northern France, balance between Roman and barbarian influences prevailed. There, the feudal system was brought to existence via a synthesis of social instruments stemming from the Roman civilization and the Germanic conquerors. Finally, in the area, which has never been in contact with the Roman world, the feudalism arose in a spontaneous way, in the course of a dissolution of pre-class kinship and tribal communities. This third zone covered an array of diversified societies, such as Anglo-Saxon, Scandinavian, Germanic, and Slavic populations.

It is noteworthy that in non-Marxian historical materialism, the model explaining the development of feudalism with an evolution of slave mode of production does not have a universal character (it is not relevant to all developmental paths of European societies). ${ }^{328}$ In fact, it is only relevant to societies belonging to the first cultural/geographic circle, in which slave mode of production prevailed.

In Slavic societies, feudalism came to existence spontaneously, in the course of a dissolution of agrarian kinship and tribal communities, and, as a result, it considerably varied from the classic Western-European feudalism. From the standpoint of the assumptions adopted in the present book, the above problematic is of secondary nature, as it only serves as a starting point for a principal empirical analysis, therefore, I will conceptualize only the structural features of Central-European feudalism in terms of $\mathrm{n}-\mathrm{Mhm}$. My analysis will not take into consideration theses stemming from individually-constructed theoretical models explaining the mechanisms of a transformation of a kinship and tribal community into a feudal system, and a transformation of the latter into a classic

327 Stanisław Russocki, “Spory o istotę i genezę feudalizmu europejskiego," Kwartalnik Historyczny, Vol. 78 (1971), p. 405; Perry Anderson, Passages from Antiquity to Feudalism (London: NLB, 1974).

328 Nowak, Property and Power, pp. 63-77. 
Western-European feudalism. For the same reason, I will restrict my argument to the case of Poland.

In a society under the "ducal law" (Ius Ducale) system, the ruling class was the lordship, termed in historical sources as the nobiles. This social class drew its power from control over the means of coercion and the means of production. Individuals recruited from this social class held offices in state administration. For instance, the administration system of the Piast dynasty had three levels of state authority: central, provincial and castellan. The central level consisted of the Duke's court and specialized agencies of state authorities, such as treasury, military commandership, etc. The state was divided into 8 provinces and around 90 stronghold districts. The lowest administrative unit was headed by a castellan who had broad competencies. He held power over local chivalry, he had judicial and police power, and his duties included collection of contributions and taxes from the peasants. Additionally, a castellan had an administrative apparatus at his disposal. It usually comprised of an officer (wojski) who dealt with military matters, a judge who had judiciary competences and a bailiff. The latter collected taxes and contributions. Finally, a castellan had an administrator (włodarz) who managed private assets of the ruler. ${ }^{329}$

The lord class owned modest land estates of their own. In Poland and in Hungary typical estates belonging to this social class did not exceed several villages. In unique cases they reached a dozen or so. ${ }^{330}$ In contrast, at the time, a castellan of a typical stronghold district held power over a 100 villages. Clerical emolument of a castellan was several times higher than the income acquired from his own economic activity. In the above-mentioned countries around $1 / 3$ of the total value of service was reserved for the emolument for clerks of the lowest administrative level. ${ }^{331}$

Following from this, in a society of the system of the Ius Ducale a double class of rulers-owners was the ruling class. As stated by Karol Modzelewski who investigated the issue, the principal source of income for this social class was governance, and not control over the means of production:

It was possible to control a massive peasant population subordinated to the Ius Ducale system only by exercising governing functions in state territorial administration and at

329 Karol Modzelewski, Chłopi w monarchii wczesnopiastowskiej (Wrocław: Ossolineum, 1987), pp. 129-132.

330 Marek Barański, "Majątki możnowładcze na Węgrzech w XII w.," Przegląd Historyczny, Vol. 70 (1979), p. 428.

331 Modzelewski, Chłopi w monarchii, p. 143. 
the Duke's court [...]. In general, this ruling class identified with higher levels of ducal hierarchy.

This should not come as a surprise in light of the information about the agrarian structure and the social condition of the peasantry. As long as landed property was a marginal phenomenon, and the greater part of rural population was subordinated only to the monarchy and the Ius Ducale, one's official functions predominantly determined high income and a high position in a society. ${ }^{332}$

In a society of the Ius Ducale, social division of the political sphere, namely identification of a social minority, which held a monopoly to use the means of coercion, brought about a growing diversification of the economy. In CentralEuropean feudalism, a duke, as a representative of the hierarchy of power, formally had all fallow and uncultivated land at his disposal. He could grant it to the Church or to the lordship. Wars were the second source of economic diversification. War trophies, particularly livestock and prisoners, were divided between the members of the ruling class. Moreover, the fate of the special category of the peasantry - the servant classes - was in the hands of a duke. He could keep them or grant them to other social subjects.

The common or simple knighthood ( $w \nmid o d y c y$ ), in historical sources typically termed as milites gregorii, constituted an intermediate layer between the peasantry and the lordship. This social group stemmed from the common people. Włodycy were better armed than other free folk, with a sword, a shield, a spear, an axe and a mount - therefore, they were more likely to participate in military expeditions. In return for their constant readiness to serve the duke, włodycy were granted an exemption from basic tributes and services. Moreover, their farmhouses were larger than peasant farms. The emergence of milites from a homogeneous mass of common people was the key moment in the process of development of the state and the dissolution of a tribal community:

$[\mathrm{W}]$ ithout a military force independent from the free folk, the monarchy was unable to become independent from a veche, to create an administrative apparatus, to monopolize judiciary system, and finally to levy tributes and services onto the greater part of country's population. [...] As a result of the division of common free folk into knights and non-knights, a class of peasants emerged as a separate category in the structure of Polish society. ${ }^{333}$

Following from this, the emergence of $w \nmid$ lodycy diversified the group of common free folk (wolne pospólstwo), who, in turn, transformed into a class of peasants.

332 Modzelewski, Chłopi w monarchii, pp. 156 and 149-150.

333 Modzelewski, Chłopi w monarchii, p. 61. 
Political authorities brought about further social division of the class of peasants. It has two additional distinguishable social layers - the so-called peasants-heirs (chłopi-dziedzice) and servants. The former constituted the core of the peasantry. They were obliged to provide a number of services and tributes in favor of the state. Karol Modzelewski conducted an analysis of the structure of peasant services in Poland. ${ }^{334} \mathrm{He}$ listed five basic tributes and services the peasantry was obliged to provide in favor of the state: stróża, poradlne, podworowe, narzaz, and an array of occasional services. Stróża consisted in keeping guard in town, however, peasantry was exempted from it in return for a suitable fee paid in grain and oat. The basis for poradlne (a tax supplied in grain) was acreage of land cultivated with two steers using scratch plough. Another service was podworowe paid once a year, with sheep, cows or rams, depending on a specified number of peasant homesteads. Narzaz was a fee paid for pig grazing in ducal forests and meadows. This tribute was collected from the entire village, in swine, and its amount was determined by the size of the total flock grazed by a village. In addition to permanent services, peasants-heirs were obliged to provide occasional services. These included: stan - an obligation to supply duke's court with water and food during a stop; przewód - an obligation to transport objects indicated by ducal officials with own means of transportation to the place of destination; powóz - an obligation to transport persons; and podwód - the Ius Ducale for temporary requisition of steers, horses and carts for war matters. Additionally, peasants had to participate in fortification works, building and restoration of towns and bridges, and in carving paths through forests. In his estimation of the size of peasant obligations under the Ius Ducale, Modzelewski states that the Ius Ducale was precedent to land governance, and was not a state addition to lord's sovereignty over the peasantry.

The second sub-category of the peasantry were servants. They had a different social condition. In return for being exempted from the greater part of services and tributes, they were obliged to perform specialized services in favor of the state. ${ }^{335}$ Based on the preserved names of towns it was possible to identify 40 different specialties, among which approximately half were craft abilities. ${ }^{336}$ Servant settlements were covering the central territory of the Piast country. In comparison to the remaining rural population, servants were economically privileged,

334 Modzelewski, Chłopi w monarchii, pp. 79-98.

335 Karol Buczek, Książęca ludność służebna w Polsce wczesnofeudalnej (Wrocław: Ossolineum, 1958), pp. 91-96.

336 Buczek, Książęca ludność służebna, p. 7. 
but they had a limited freedom. Servants performed obligations to the duke hereditarily, so they could not choose their place of residence or profession. ${ }^{337}$

In his analysis of the services in kind, which resulted from the Ius Ducale, Modzelewski states that "the structure of obligations resulting from the Ius Ducale in its most popular version was predominantly characterized by a collage of various needs and duties designed to satisfy any request of the ruler or state apparatus." 338

The status of peasants-heirs and their entitlement to land was an impediment on the path of development of grand land ownership. Grand ownership could come to existence only if a duke resigned from a prerogative of public power judiciary and economic - and pass it onto owners. The first institution to make a breakthrough in the system of the Ius Ducale was the Church. In the course of bestowing immunities, this institution was being granted land together with people living on it, who used to be subjugated to the Ius Ducale, since the end of the 11th century. By granting land, a duke would give up his claim from the Ius Ducale to the people residing on. At first, state officials opposed the immunity action because it reduced the economic position of this social group. However, as the state fragmentation was progressing and the group of persons holding the highest positions grew from a dozen or so in the 11th century to two hundred in the 12th century, the resistance of this social group weakened. The land of the officials was gradually becoming more important than their emolument. In the 12th-13th centuries, the immunity action spread to other social circles, particularly the nobility and knighthood. ${ }^{339}$

The system of the Ius Ducale prevailing in Hungary, Bohemia, and Poland remained a contentious issue in historical literature. Let us now present two interpretations of the system and a characteristic of the Ius Ducale society in the conceptual apparatus of non-Marxian historical materialism. ${ }^{340}$

337 Karol Modzelewski, Organizacja gospodarcza państwa piastowskiego (X-XI w.) (Wrocław: Ossolineum, 1975), p. 12.

338 Modzelewski, Organizacja gospodarcza, p. 180.

339 For a description of the process of development of grand feudal ownership, see: Wacław Korta, "Rozwój terytorialny wielkiej świeckiej własności feudalnej w Polsce do połowy XIII wieku," Sobótka. Śląski Kwartalnik Historyczny, Vol. 16, No. 4 (1961), pp. 528-566.

340 For other conceptualizations, see: Nerijus Babinskas, “Od feudalizmu do afrykańskiego sposobu produkcji. Problem typologii przednowoczesnych peryferyjnych społeczeństw europejskich," Człowiek i Społeczeństwo, Vol. 42 (2016), pp. 119-133. 
Henryk Łowmiański distinguishes between two forms of social pre-capitalistic organizations - a so-called Asian and a feudal production system. ${ }^{341}$ In light of historical records, the evolution of pre-class societies toward slavery is an exception, and not a rule. According to Łowmiański, in an empirical world, a so-called Asian production system was much more popular. It:

[p]resents [...] a form of non-individual, collective exploitation of producers by social elites using state authorities, while the exploited population may be organized into village communities (wspólnoty gromadzkie), a continuation of pre-state communities. ${ }^{342}$

Feudalism, in turn, is a system founded on a serfdom-based dependency of the peasantry from the class of feudal lords, which has the attributes of a public and private authority. This social system has a centralized and a decentralized form. Centralized feudalism was characteristic for the terrains situated outside the borders of the Roman Empire. Following from this, the social system prevailing in Central Europe between the 10th and the 12th centuries was a centralized form of feudalism. In this system, the state served merely as an instrument of exploitation of the peasantry by the feudal class: "The early-feudal period was dominated by a form of exploitation, which could be termed as collective and which was implemented via state."343

Centralized feudalism was an early form of a social system, which would have been at some point subject to decentralization. The reason for this was that the early-feudal monarchy "[h]ad performed its class duty by organizing exploitation of the producers, and now attempted to disrupt the ongoing process of subordinating producers directly to feudal lords, not to the monarchy."344

Modzelewski puts forward a different interpretation of the system of the Ius Ducale. He explains dissimilarities in the development of Central-European feudalism with a different socio-economic background. The Přemyslid, Árpád, or Piast monarchies arose outside the Carolingian succession and the Roman influences, and did not have a system of private land ownership. Tribal and kinship system, in turn, prevented creation of grand ownership at the expense of common free folk:

341 Henryk Łowmiański, "Przemiany feudalne wsi polskiej do 1138 r.," Przegląd Historyczny, Vol. 64 (1974), p. 438.

342 Łowmiański, “Przemiany feudalne," p. 436.

343 Henryk Łowmiański, "Podstawy gospodarcze i społeczne powstania państwa polskiego i jego rozwoju do początku XII w.”, Kwartalnik Historyczny, Vol. 67 (1960), p. 965.

344 Łowmiański, "Podstawy gospodarcze," p. 966. 
The assets belonging to tribal aristocracy did not exceed a modest level because the social structure prevented them from growing. It proved impossible to force the masses of common free folk to work for a third party. Aristocracy could not deprive them from their freedom or land. Tribal authorities were unable to levy more substantial tributes. It was itself dependent on the "Noble Host" (a mass mobilization; pospolite ruszenie) in every military need and on the participation of the administrative unit of opole in every internal undertaking. In order to impose substantial economic obligations on the common free folk, the authorities would have to have a military force independent from the people and an administrative apparatus capable of using coercion. ${ }^{345}$

As a result, the only solution was to enforce slavish ties indirectly, that is to say, via a growing state apparatus, which levied tributes and services on the peasant population. According to Modzelewski, "the system of obligations of the Ius Ducale was constructed with a view to directly satisfy the largest needs of the state, and not to increase the purely quantitative maximization of the incomes." ${ }^{46}$

In Modzelewski's interpretation, the state is not only an instrument used by the economically-ruling class because there was simply no such class at the time of emergence of the state. This class came to existence when the system of state servitude collapsed. The principal function of the Ius Ducale was to satisfy the demands of the state. It only indirectly ensured fixed income to the ruling class.

Modzelewski argues that the system of the Ius Ducale should be analyzed with reference to two systems: Western-European feudalism and the Asian production system. The differences between the Central-European society and the model of Western feudalism include: "the identity of the ruling class and the state hierarchy," "indirect exploitation of all people based on common duties for the benefit of the monarchy," "absence of the attributes of personal or land dependency," and "development of a class system on the fundament of formally inviolable right of the common people to land and other tribal institutions."347

The above-listed features differentiating the system of the Ius Ducale from the classic feudal system bring to mind an analogy with the so-called Asian production system. According to Modzelewski, however, these two systems should not be identified. In the Asian system of production, the state served as a coordinator and promoter of production. In this social system, land was a property of individual agrarian communities stemming from the pre-state period. These communities paid tributes to the state and performed services. Following from this, Modzelewski concludes his argument in the following way:

345 Modzelewski, Chłopi w monarchii, p. 52.

346 Modzelewski, Organizacja gospodarcza, p. 181.

347 Modzelewski, Chłopi w monarchii, p. 266. 
Eastern-European monarchies differed from Asian despotic systems by a technological gap with all its consequences concerning organization of a society and its structural dynamics. The general social functions of the state were limited to defense, judiciary and police-organizational obligations, and did not include organization of agricultural production. In this aspect, a peasant family constituted an economic entity with a substantial scope of productive independence; in fact, it corresponded with an individual system of expropriation of land (...). In this aspect, the system of the Ius Ducale and classic Western-European feudalism were based on a similar civilizational fundament. "State servitude" became a starting point for the processes of feudalization, which finally blurred the primary difference between the structure of the two systems. ${ }^{348}$

Let us now attempt to characterize the Ius Ducale society in notion apparatus of $\mathrm{n}-\mathrm{Mhm}$. Among supra-class societies there are distinguished two kind of totalitarian societies characterized by the concentration of the means of coercion and production in the hands of a single social class. In the political variant of a totalitarian system, political interest, namely the maximization of power regulation, dominates over economic interest, namely the maximization of the surplus product. In the economic variant of a totalitarian system, the maximization of profits dominated over the maximization of power regulation. The above should be perceived as pure cases of supra-class systems in n-Mhm. Additionally, the theory recognizes quasi-totalitarian societies. These are societies, where single classes of rulers and owners accompany the double class of rulers-owners. Quasitotalitarian systems may also have both of the above-mentioned variants: political and economic.

The above description of the system of the Ius Ducale proves that countries under the rule of Přemyslid, Árpád or Piast dynasties were not standard class societies. They were closer to quasi-totalitarian societies. Nobiles - the ruling class in the Ius Ducale society combined political and economic power. As a result, this social group was a double class of rulers-owners. In the above system, the double class of rulers-owners gained its principal income from holding power, and not from possession of the means of production, which were of a rather unsubstantial size. The class of individual owners - włodycy arose beside the double class of rulers-owners. Therefore, it is possible to interpret the status of $w \nmid o d y c y$, who owned land estates, but did not belong to the double class of rulers-owners. To paraphrase Łowmiański's interpretation in terms of n-Mhm, we may assume that the Ius Ducale system was an economic variant of a (quasi) totalitarian system. And in Modzelewski’s view, the system was a political variant of a (quasi) totalitarian system.

348 Modzelewski, Organizacja gospodarcza, p. 267. 
The collapse of the system of the Ius Ducale may be interpreted as the process of detotalitarianization. The process consisted in a development of a single class of owners and emergence of a class (economic) society. The above statement allows us to determine the period of the implementation of the model of an economic society with a shortage of manpower. The theses of this model are relevant for an economic society with separate social classes. Hence, they do not apply to societies of the Ius Ducale, regardless of the type of the (quasi) totalitarian system they may represent.

Thus, the formation of a class society took place at the turn of the 12th and the 13 th centuries. The process determines the beginning of the validity of the theses of the model of an economic society with a shortage of manpower.

\section{The Emergence of a Cascade of European Differentiation}

\subsection{The Core of the Cascade of European Differentiation}

The system of the Ius Ducale finally disappeared from in central-European societies in the 12th-13th centuries. A ruling class of rulers-owners gave rise to a single class of owners, which obtained immunity and took over a part of judicial and tax prerogatives of the political authorities over the subjects. In turn, came to existence a society, which evolved according to the mechanism of economic society, where the class of owners plays the main role. In this period analogically to Western Europe - towns emerged and expanded, rent economy prevailed in the rural areas, and the traditional forms of natural economy were being replaced with the developing commodity-monetary economy.

However, since the turn of the 15th and the 16th centuries, the distinctiveness of the developmental path of Central-European countries gradually increased in comparison with Western Europe. The river Elbe became the borderline between two developmental zones. West of the river, towns, craft production and manufacture continued to expand, and peasants gained personal freedom. The social balance between burghers and the nobility enabled the state to gain in power and to transform from a state monarchy into an absolutist monarchy in the modern period. By contrast, east of the river Elbe, the towns in all countries of the region experienced a significant crisis - a decrease of population and craft production. In the rural craftsmanship, the development of a manorial-serf economy superseded the earlier monetary economy. The process was accompanied by the growth of obligations imposed by the lords over the peasantry and introduction of the so-called second serfdom. The economic superiority of the nobility was also strengthened in political life - in all Central-European societies, burghers 
had unsubstantial impact on public life, in comparison with Western Europe, whereas the state was subordinated to the interests of the nobility. The rise and development of a manorial-serf economy, which allowed for an increase of exploitation of the peasantry, was the basic factor bringing about a differentiation between two basic economic zones in modern Europe. According to Phillip Longworth, the economic system exerted a permanent influence on the development of Central Europe:

the imposition of serfdom established a profound difference between Eastern and Western European society. This difference had important cultural and moral dimension, affecting not only the serfs, whom it degraded, but their owners, many of whom were corrupted by the almost absolute power they wielded over them. As we have seen serfdom lasted very much longer in Eastern Europe than in the West, exerting a profound effect both on popular and elite attitudes down to the present day. The modern tendencies towards a disorderliness tempered by servility, and even anarchy, owes much to the heritage of serfdom. The effects of serf-owning is reflected, arguably, in the ready contempt shown for those who hold a different view, the common failure to comprehend pluralistic structures, and the tendency to confuse self-respect with the domination of others. ${ }^{349}$

The growing differentiation between Western and Central-European societies may also be conceptualized in the conceptual apparatus of non-Marxian historical materialism. A gradual increase of the alienation of labor takes place in the first stage of development of a typical Western-European society. However, an intensification of exploitation does not bring about an economic evolution because in the final stadium of the phase of an increased alienation of labor a technical advancement occurs - new tools and technologies of production appear. The development of production forces divides the economy, by breaking the class of owners into two sub-categories: owners of the new sphere of production (burghers) and owners of the old sphere of production (nobility). The division of the homogeneous class of owners into two fractions helps political authorities to liberate themselves from the influence of both fractions. Initially, the authorities enter an alliance with the weaker fraction of the class of owners (burghers) directed against the stronger fraction (nobility). Subsequently, when the greater part of the social product is manufactured in the urban sector of the economy, the class alliance is reversed - the authorities enter an alliance with the nobility, which is the weaker element in the economic system. As a result, the political authorities liberate themselves from the influence of grand ownership

349 Phillip Longworth, The Making of Eastern Europe (Londyn; The Macmillian Press, 1992), p. 298. 
and gradually etatized all spheres of social life. This is the image of the development of Western societies according to the $\mathrm{n}-\mathrm{Mhm}$ model of feudalism. However, it does not correspond with the evolution of Central-European societies.

A drop of the alienation of labor characterized the first stage of development of a class society in Central Europe. This is how we may interpret the development of German colonization and settlement with German Law. In this period, the economy divided into two sectors - towns and burghers arose. However, from the very beginning, the contribution of the urban sector of economy to production and the impact of burghers on public life in a typical CentralEuropean society were smaller than the socio-economic influence of owners of the new sector of production (burghers) in a typical Western-European society. The division of the - until then homogenous - class of owners into two subcategories (burghers and nobility) allowed the authorities to end a political collapse caused by state fragmentation, but the weak condition of towns triggered by a number of secondary factors made it impossible for the Central-European society to develop analogically to Western-European societies. In a typical Central-European society, the class of owners of the old sphere of production (nobility) exerted domineering influence on public life. The nobility managed to subordinate authorities to its interests and use them to limit the prospects of expansion of the alternative field of production - the urban sphere. The subordination of the political power and limitation of developmental perspectives of the new sphere of production allowed for an increase of the alienation of labor in the old sector of economy (agriculture), which limited the developmental prospects of the new sector (towns).

Let us now conduct an empirical analysis of the factors, which brought about a developmental distinctiveness between Western and Central Europe. The factors appearing in the cascade of European differentiation include its core, or a set of variables which operated in each of the societies under study - Polish, Hungarian and Bohemian - and specific factors responsible for the development of each of those Central-European societies. Th shortage of manpower was a factor, which initiated the build-up of the cascade of European distinctiveness. The level of population density was one of the significant factors deciding on the socio-economic specificity of Central Europe and, hence, it requires attention. The disproportions between Western and Central Europe concerning the level of population density derived from the times of the Roman Empire. In the 1st century, the Roman part of the European continent, namely west of the Rhine and south of the Danube, was inhabited by ca. $70 \%$ of the continent's population. Ten centuries later, around $65 \%$ of the continent's population still lived in the area. In the 10th century, about 49 million people inhabited Europe. At that time, 
the population of France was 9 million, Italy - 7 million, Germany - 5.4 million, England and Wales - 2.5 million. Central-European countries of those times were respectively less populated: Poland had a population of 1.25 million, Bohemia and Moravia that of 1 million, Hungary - around 1 million. Population density in particular countries was just as irregular: for instance, in Italy there were 24 people per square km, compared with 16 in France, 10 in Germany and 8 on British Isles, whereas in Poland the respective figure was 5 people and 8 people in Bohemia. ${ }^{350}$

Henryk Samsonowicz and Antoni Mączak identify three population zones. The most populated zone, with the density above 20 people per square $\mathrm{km}$, stretched from England to the Apennine Peninsula and covered the following countries: Italy, central and northern France, western and southern Germany, and England. Along both sides of that area, there stretched the terrains with a population density between 8 and 15 people per square km. Southern France, Spain, and Portugal were situated to the west of that zone, and to the east were Denmark, Mecklenburg, Poland, Bohemia, Hungary, and the Baltic states. Apart from the two zones, the above-mentioned authors distinguish an area of the lowest population density (up to 2 people per square $\mathrm{km}$ ) with Russia and the Scandinavian countries. As a result, Central-European societies were located between the second and the third zone. ${ }^{351}$

In the middle of the 14th century, Western Europe was touched by a plague epidemic, which equaled to a demographic catastrophe for this part of the continent. The plague reduced the continent's population by $25 \%$ in comparison to its initial state. ${ }^{352}$ As a result, the loss of population in particular areas of England was equal to $23 \%-45 \%$, compared to $25 \%-35 \%$ in France, $40 \%-60 \%$ in northern Italian towns, $30 \%$ in Spain and $25 \%-75 \%$ in Germany, in comparison to its initial state. ${ }^{353}$ Such a significant drop of population density was caused by considerable over-population of Western Europe when combined with technological capabilities of the Medieval economy. The epidemic of the

350 Małowist, Wschód a Zachód, pp. 18-21.

351 Henryk Samsonowicz and Antoni Mączak, "Feudalism and Capitalism: a Balance of Changes in East-Central Europe," in: Central Europe in Transition. From the Fourteenth to the Seventeenth Century, eds. Peter Burke, Antoni Mączak and Henryk Samsonowicz (Cambridge: Cambridge University Press, 1985). p. 8.

352 Josiah Cox Russel, "Population in Europe 500-1500," in: The Fontana Economic History of Europe. The Middle Ages, ed. Carlo M. Cipolla (London-Glasgow: Collins, 1972), p. 41.

353 Anna Rutkowska-Płachcińska, "Dżuma w Europie Zachodniej w XIV w. - straty demograficzne i skutki psychiczne," Przegląd Historyczny, Vol. 69 (1978), p. 69. 
plague did not affect Central-European countries. ${ }^{354}$ On the contrary, societies of this region experienced a population growth between the 13th and the 17th centuries. In the first half of the 14th century, the population of Poland increased to 1.8 million people, of Bohemia to 2 million, and of Hungary to 2.5-3 million. In modern times, the population of Hungary was equal to 4 million of people (the turn of the 15th and the 16th century), Bohemia had a population of 2.4 million people (the end of the 16th century) and Poland -4 million (the turn of the 15th and the 16th century). A substantial decrease in the population of Central-European countries was a consequence of wars, famine and epidemics in the 17th century. As a result of the losses caused by the Turk occupation, the population of Hungary dropped at the end of the 17th century to 2.5-3 million people, the population of Bohemia and Moravia to 0.9 million and the population of Poland equaled 6 million people at the beginning of the 18th century (a drop from 10 million in the middle of the 17th century). ${ }^{355} \mathrm{~A}$ low level of population density stimulated feudal lords to grant concessions to the peasantry. To a certain extent, the feudal class relinquished their prerogatives obtained from political authorities and granted wide-ranging privileges to the settling population of peasants. The settlement movement understood as above lasted from the 13th to the 14th century in all Central-European societies. Thus, the period of German colonization and settlement with German Law, which brought about a substantial improvement of the situation of the peasantry, may be interpreted in terms of a decrease of the alienation of labor in model III of an economic society.

Let us now take a closer look at the mechanisms of the colonization. ${ }^{356}$ The organization of colonization involved three parties: a feudal lord, a promoter

354 Karl Helleiner, "The Population of Europe from the Black Death to the Eve of the Vital Revolution," in: The Cambridge Economic History of Europe, Vol. 4: The Economy of Expanding Europe in the XVIth and XVIIth Centuries, eds. E.E. Rich and Charles Wilson (Cambridge: Cambridge University Press, 1967), p. 38.

355 Eric Fügedi, “The Demographic Landscape of East-Central Europe," in: Central Europe in Transition. From the Fourteenth to the Seventeenth Century, eds. Peter Burke, Antoni Mączak and Henryk Samsonowicz (Cambridge: Cambridge University Press, 1985), pp. 47-59; Małowist, Wschód a Zachód, pp. 19-20; Stanisław Russocki, "Monarchie stanowe środkowo-wschodniej Europy XV-XV1 w.," Kwartalnik Historyczny, Vol. 84, No. 1 (1977), p. 75.

356 Andrzej Gąsiorowski, “Ze studiów nad szerzeniem się tzw. prawa niemieckiego we wsiach ziemi krakowskiej i sandomierskiej (do roku 1333)," Roczniki Historyczne, Vol. 26 (1960) pp. 123-170; Adrienne Kormendy, "Kształtowanie się pojęcia 'prawa niemieckiego' (ius Teutonicum) w Europie środkowo-wschodniej w XIIIXIV wieku," Przegląd Historyczny, Vol. 75 (1984), pp. 481-491; Małowist, Wschód 
of the location (zasadźca), and peasant-colonists. Grand landowners predominantly initiated settlement because they were the first to obtain immunity, and they were able to bear all costs associated with the execution of German settlement, such as: integration of agricultural land, importation of settlers and, most importantly, all costs of securing proper economic conditions for settlers, which usually included dozen or so years of exemption from taxes and obligations.

A promoter of the location bore the greater part of direct costs associated with the process of location. For this reason, a successful location brought him the largest benefits. A promoter of location received the largest parcel of land - ca. $10 \%$ of the settled terrain. The land was exempted from taxes and tithe. After a successful village location, the majority of promoters served as village headmen. This position brought further privileges, such as the right to catch fish, a share in taxes paid by millers and innkeepers, etc. In return for the received privileges, village headmen had a number of obligations. The most significant was to perform military service as a cavalry soldier. As early as in the 14th century, this service was passed to the chivalry via grants and purchase. Other duties of village headmen included collection of rent and tithe, offering hospitality to the lord of the village and to Church dignitaries. The most serious obligation was to exercise judicial authority, together with jurors selected from the village assembly (gromada). Village headmen received a substantial income from court fees.

The system of German Law was a reception of institutional solutions known at the West of Europe and applied by feudal lords with respect to the peasantry. Still, it was also a manifestation of economic concessions of the single class of owners. German Law endowed peasants with personal freedom and the right to leave the village. It guaranteed hereditary ownership of the land. Within their class, peasants could dispose of their land as they wished, sell, or rent it. However, the sale of land to another knight or Church required separate consent from the lord. Inhabitants of villages founded with German Law also enjoyed a guarantee of immovability from land, which they cultivated. Moreover, the village received a judicial self-government. Settlement of new terrains was accompanied by long-lasting exemptions from payments and taxes (around 10-15 years).

a Zachód, pp. 13-14; Jerzy Piskorski, Kolonizacja wiejska Pomorza Zachodniego w XIII i w początkach XIV wieku na tle procesów osadniczych $w$ średniowiecznej Europie (Poznań: PTPN, 1990), pp. 174-178; Kazimierz Tymieniecki, "Prawo niemieckie w rozwoju społecznym wsi polskiej," Kwartalnik Historyczny, Vol. 33 (1923), pp. 38-79; Benedykt Zientara, “Źródła i geneza 'prawa niemieckiego' (ius Teutonicum) na tle ruchu osadniczego w Europie zachodniej i środkowej w XI- XII w., Przegląd Historyczny, Vol. 69 (1978), pp. 47-74. 
These rights were vested not in individuals but in village communes. The privileges, which were initially granted only to settlers, were later extended to local population.

German colonization brought about direct benefits, such as a considerable increase of population potential of countries, in which German settlement was conducted. Population density of Bohemia, which was 6 people per square $\mathrm{km}$ in the 11th century, increased in the 14th century to 14 . Hungary saw a similar population growth. In 1000, this country had a population of about 1 million. In the middle of the 13th century, in spite of the losses brought about by the Tartar invasion, the Hungarian society had 2 million people, and in the beginning of the 16th century it reached 4 million. At that time, Poland also observed a demographic increase. In the 11th century, the average population density was 5 people per square $\mathrm{km}$. In the middle of the 14 th century, the average population density was 8 people per square $\mathrm{km}$ to reach 15 people in the 16 th century. ${ }^{357}$

German colonization and settlement with German Law contributed to the growth of productive forces in Central-European societies. Most changes in that respect were brought about by the spread of the three-field system. In the alternate-fallow system, an average family needed 34 ha of cultivated land to make a living, whereas they had the total of 100 ha to use. In contrast, in the three-field system, an average family could make a living of 4-8 ha. Following from this, in the three-field system the area of cultivated land equal to 100 ha could feed from 30 to 60 people. ${ }^{358}$ The 13th and the 14th centuries witnessed a widespread of newly invented agricultural tools. One of the most important tool was iron plough. Its iron parts were used to loosen heavier and more fertile soils, inaccessible to a shovel plough. At the same time, apart from the iron plough, other agricultural tools, such as frame harrows, scythes, spades, and axes, came into common use. ${ }^{359}$

The above changes in agricultural technology brought about a considerable increase in crop yield. In the 10th and the 11th centuries, the average harvest amounted to ca. 1.5-3 grains from one seed. Half of the acquired grain had to be reserved for the next year's sowing. The other half, after the diminution of tributes and taxes, remained at the disposal of a peasant. ${ }^{360}$ As a result of changes

357 Piskorski, Kolonizacja wiejska, p. 241-242.

358 Henryk Łowmiański, Początki Polski, Vol. 3 (Warszawa: PWN, 1967), p. 312.

359 Zofia Podwińska, Technika uprawy roli w Polsce średniowiecznej (Wrocław-WarszawaKraków: Ossolineum, 1962), pp. 174-176.

360 Łowmiański, Początki Polski, p. 307. 
in cultivation technology in the 13th and the 14th centuries, the yield increased to 3-4 grains from one seed and to 5 grains on some lands. As a result, average harvest ranged at that time from 4 to 5 grains from one seed. From the middle of the 12th century to the middle of the 14th century, agricultural production in Central Europe increased by around 30-65 \%, and in certain areas it even doubled. ${ }^{361}$

As early as in the 12th century, German colonization and settlement with German Law covered the terrains between the rivers Oder and Elbe. At that time, certain groups of Romance origin were settling in Hungary. In the 13th and 14th centuries, German colonization reached Silesia, Pomerania, Greater Poland, Lesser Poland, Bohemia, Moravia, Slovakia, Transylvania and Hungary, but also Prussia and Livonia. The center of German settlement was Silesia. It spread from there onto other terrains. There where ca. 1200 villages founded in Silesia in the years 1200-1350. From the 12th to the 14th century, according to German historiographic estimates, around 180,000-200,000 settlers were to have reached that land. Another important agglomeration of German settlement was Eastern Prussia. About 1400 villages were founded there, inhabited by 150,000 settlers. ${ }^{362}$

Grand ownership pursued German colonization to increase income. Under the conditions of low population density in Central-European countries, the only way to ensure stability and multiply income was to increase the number of serfs. The factor of shortage of manpower, according to Małowist, allows us to understand the mechanisms of reasons why grand ownership pursued German settlement:

[A] relatively low population density of Central-Eastern and Eastern European countries was an important factors influencing rotation of workforce in rural areas. Due to a low level of population density, rulers and the aristocracy had to resort to economic means to stimulate inflow of foreign and domestic population, to end escapes and to encourage people to work harder. ${ }^{363}$

An additional factor facilitating organization of German settlement was the growing overpopulation of Western-European societies. At this time (between

361 Piskorski, Kolonizacja wiejska, pp. 242-245.

362 Herman Aubin, "The Lands East of the Elbe and German Colonization Eastwards," in: The Cambridge Economic History of Europe, Vol. 1: From the Decline of the Roman Empire, eds. John Harald Clapham, Eileen Power (Cambridge: Cambridge University Press, 1942), pp. 396-397.

363 Małowist, Wschód a Zachód, pp. 15-16. 
the 12th and the 14th centuries), Germany, a country neighboring Poland and Bohemia, with:

population density of around 20 people per square $\mathrm{km}$, reached the maximum level of population advancement possible under the given level of productive forces in agriculture. Consequently, it was sending its population surplus to the east of Europe. Similarly, France was sending its population surplus to the remote terrains subjected to crusades. ${ }^{364}$

Małowist puts forward the following question: why did the reorganization of class relations in the agricultural segment take place at the turn of the 12th and the 13th centuries? ${ }^{365}$ His analysis consists of three factors. The period between the 10th and the 13th centuries in Poland, Hungary and Bohemia was characterized by a slow economic development, which deepened political disproportions between the above-listed countries and their considerably more powerful western neighbors. A vast difference in socio-economic potential could have threatened the political existence of the above-mentioned Central-European countries in the future. Moreover, in this period (the 12th and the 13th centuries), CentralEuropean countries were in a situation of a political balance, which hindered acquisition of economic possessions through wars and invasions. Additionally, a consolidation of grand secular and church property took place. The Church was the first to be granted revenue and judicial privileges from rulers, and was able to initiate German settlement, a process which dynamized the economic development of Central Europe.

In my opinion, model III of an economic society developed in the previous chapter is capable of providing an answer to the question posed by Małowist. We should begin by stating that in the Middle Ages, virtually entire Europe experienced the following phenomenon: the class of owners was granting economic concessions to direct producers. The reason for granting concessions was different for Western and different for Central Europe. According to the model of feudal economy in $\mathrm{n}-\mathrm{Mhm}$, in the final stadium of the phase of an increasing alienation of labor, technological advancement brings about an emergence of a new economic sector. Initially, in the new sphere of production, namely the urban sector of economy, a lower level of alienation of labor prevails, in comparison to the old sector (agriculture). As a result, the most dissatisfied peasants (the class of direct producers of the old sphere of production) move to towns on a massive scale. Consequently, the growing social conflict in the old sphere

364 Stefan Kurowski, Ludność w historii i w polityce (Warszawa: Ośrodek Dokumentacji i Studiów Społecznych, 1980), p. 32.

365 Małowist, Wschód a Zachód, pp. 20-23. 
of production (agriculture) sorts itself out spontaneously. However, a further exodus of the peasantry from rural areas may bring about a disorganization of production. Feudal lords introduce new systems of organization of production in order to stop the migration of the peasantry. They are more advantageous to the rural population and allow for achievement of higher income. Accordingly, the level of alienation of labor drops in the old system of production. Thus, the economic impact of the new sphere of production (the urban economy) forces the class of owners of the old sphere of production (agriculture) to grant concessions. Such a picture of historical development is emerging in light of the model of feudalism in $\mathrm{n}-\mathrm{Mhm}$.

In contrast, economic concessions in a typical Central-European society were not enforced by the competition between two alternate fields of production the agricultural and the urban sector, but by the competition between owners belonging to the old sphere of production (feudal lords). According to model III of an economic society with a shortage of manpower, in order to increase profit to maximum, owners are forced to find a way to transform the system of division of the newly created production to the advantage of employees to acquire as many direct producers as possible. An increase of exploitation in a purely economic society is ineffective in a long-term perspective. Under the conditions of shortage of manpower, the alienation of labor does not increase endlessly. After reaching a certain level, increasing instances of escapes and migrations of the peasantry to owners who apply less severe forms of exploitation result with a disorganization of the production process. Pressured by the desertion of the peasantry, owners who introduce more rigorous systems of expropriation of the secondary product are forced to mitigate their ways not to lose the remaining producers. In a purely economic society - a society deprived of administrators of means of coercion, the level of alienation of labor stabilizes in the area of class peace. Following from this, in a society with a shortage of manpower, the only way to maximize profits is to acquire new direct producers by creating better working conditions, in which they will be able to achieve higher income. To answer the question why the reorganization of the class rule by grand ownership became possible as late as at the turn of the 12th and the 13th centuries, one must analyze the reasons for the collapse of the system of the "ducal law." According to historians, the system of the Ius Ducale was based on a collective economic exploitation of the peasant population by the apparatus of state. Whether the apparatus of state exploited the peasants in its own interest, or whether it worked on behalf of another social class, does not exert a direct influence on the issue under study. Importantly, collective exploitation of the peasant population eliminated the competition between owners. In the times of competition, each owner 
had to fight for workforce. Noteworthy, under the conditions of shortage of manpower, competition between owners enforces economic concessions on the part of those in control of the means of production, which, in turn, brings about a global decrease of the level of alienation of labor. However, the above factor becomes ineffective in the system of state serfdom, where the apparatus of power, which is a collective owner of the workforce of direct producers, eliminates competition between owners. It was not until the dissolution of the system of the Ius Ducale, which brought about a creation of a single class of owners, which gained the greater part of its income from ownership of the means of production, and not from being part of political authorities. The process of granting concessions, which brought about a process of voluntary mitigation of serfdom, not enforced by a threat of peasant revolts, was initiated by the competition between feudal lords and the inability to refer to state authorities - between the 12th and the 14th centuries, Bohemian, Polish, and Hungarian societies experienced a feudal fragmentation and a collapse of political power. ${ }^{366}$

The level of population density in Central-European countries influenced the evolution of urban economy in this part of the continent. As a result of a lower level of population density, a lower number of people lived in Central-European towns in comparison to Western-European urban populations. Additionally, the emergence of the urban economic sector in Central Europe took place in the stadium of mitigation of exploitation, brought about by a shortage of manpower. As a result, rural population did not have to migrate to towns in search for better conditions of employment, as it was in Western Europe. For this reason, the urban population in Central Europe was smaller in comparison to the situation in Western-European towns. In the latter part of the continent, towns evolved with an increase of the alienation of labor in the agricultural sector of the economy. Following from this, the urban population in Central Europe was of foreign origin - particularly German and Jewish.

Let us now follow these processes in detail. In the 12th and the 13th century, technological progress and related phenomena, such as a growth in production and specialization and division of labor, gave rise to the development of towns in Central Europe. The urban reform usually began by granting legal autonomy to foreign merchants who lived in proto-urban settlements. A spatial location was the second stage. It usually consisted in founding towns from scratch or in reconstructing existing settlements. The municipal reform in this sense began at the turn of the 12 th century. Population centers, which made a

366 Tymieniecki, “W sprawie zaostrzonego poddaństwa," p. 304. 
living outside farming, existed in that part of the continent as early as in the period from the 10th to the 12th centuries, and even in the pre-state period. Location consisted in establishing new towns or granting municipal rights to the centers of settlements, which had existed before location. The promoters of location were rulers, feudal lords or the Church. Locations brought profit to all parties involved: a owner, settlers-burghers and a promoter of location. A feudal lord, in consequence of a successful location, exercised control over rent that he received from the plots on lease, and obtained merchant and market fees, rent paid by craftsmen, etc.

Settlers, on the other hand, enjoyed suitable conditions for initiating an economic activity. They acquired their own jurisdiction and were granted exemptions from taxes. A feudal lord also bestowed privileges on them, which facilitated an economic and commercial activity. Here are examples of privileges: the privilege to set up a marketplace, exemption from customs, to have goods in stock, and the so-called "mile law" that restricted competition within rural craft by indicating the radius within which trade was prohibited.

Finally, location was rewarding for its promoter. He usually became a vogt (wójt), i.e., a representative of the feudal lord who was the founder of the town. The promoter usually received a larger plot of land; he enjoyed the right to use the lord's woods and waters. Since he represented the owner, he also exercised judicial and supervisory authority, and enjoyed revenue and tax privileges. Municipal law in Central-European towns was based on the Magdeburg Law, whereas the organization of the Baltic towns was based on the Lübeck Law. ${ }^{367}$

The above reform has been introduced until the middle of the 13th century into 144 town centers in Central Europe, including 60 towns or $24 \%$ of proto-urban centers in Poland, and 14 towns or $14 \%$ of proto-urban centers in Bohemia. ${ }^{368}$ The location of towns should not be identified with urban self-government, which usually appeared later, simultaneously with the formation of the town council. As a result, in the initial period, urban authority belonged to the representative of a feudal lord - the town headman. However, after some period of diarchy, a town council usually bought out the rights of the owner of the town. Purchase of the town headman's rights was considered the third stage

367 Cf. Maria Bogucka and Henryk Samsonowicz. Dzieje miast i mieszczaństwa w Polsce przedrozbiorowej (Wrocław: Ossolineum, 1986); Piskorski, Kolonizacja wiejska, p. 246.

368 Andrzej Wędzki, Początki reformy miejskiej w środkowej Europie do poł. XIII wieku (Słowiańszczyzna Zachodnia) (Warszawa: PWN, 1974), p. 234. 
in the evolution of Central-European towns and took place later, in the 14th and 15th centuries. ${ }^{369}$

Following from this, it is evident that Central-European towns evolved under the patronage of grand ownership, rather than in opposition to it. As a result, Central Europe did not witness an urban revolution that was characteristic for Western Europe of the 10th and 11th centuries, during which burghers gained independence and autonomy from feudal lords. Another characteristic trait of Central-European towns was their small size. In his comparison of towns of Western and Eastern Europe, Henryk Samsonowicz states, for instance, that around 1450 Europe had about 4,000 settlements called towns. ${ }^{370}$ About two thirds of that number were rural settlements. Out of 14 largest towns (with a population of over 40,000) only three were situated in Eastern Europe: Moscow, Prague and Constantinople. Out of those three, only Prague, ranking low within the category of the largest towns, was situated in Central Europe. Out of the around 40 large towns with a population ranging from 20,000 to 40,000, five were situated in Eastern Europe: Lübeck, Gdańsk, Novgorod, Wrocław, and Thessaloniki. Thus, Central Europe in the middle of the 15th century had only 3 large towns. About 80 towns belonged to the category of medium towns, with a population ranging from 8,000 to 20,000 inhabitants. In Eastern Europe, there were about 30 towns that belonged to that category. They included Cracow, Torun, Elbląg, Lvov, a few Silesian towns, Kaliningrad, Riga, Szczecin, Wismar, Stralsund, Rostock, Magdeburg, and a few Russian, Bohemian, and Balkan towns. In Central Europe of that period, there were around 20 medium-sized towns that is ca. $25 \%$ of the overall number of towns from that category. There were around 120 small towns with a population of 2,000-4,000 in Eastern Europe among around 400 towns of that size.

The weakness of Central-European towns, in comparison to the rapid development of Western-European urban centers, affected the nature of trade exchange between the Western and Central Europe. A unilateral trade exchange between the two parts of the continent developed in the late Middle Ages. Such state of affairs was maintained and even extended in the modern period. A shift

369 Wędzki, Początki reformy miejskiej, p. 208; Benedykt Zientara, "Przemiany społecznogospodarcze i przestrzenne miast w dobie lokacji," in: Miasta feudalne w Europie środkowo-wschodniej. Przemiany społeczne a układy przestrzenne, eds. Andrzej Gieysztor and Tadeusz Rosłanowski (Toruń: Polskie Towarzystwo Historyczne, 1974), pp. 8-9.

370 Henryk Samsonowicz, “Europa jagiellońska - czy jednością gospodarczą," Kwartalnik Historyczny, Vol. 84 (1977), pp. 94-96. 
in trade routes took place at that time: Levantine and Mediterranean commerce lost its importance and was replaced by Atlantic and Baltic trade. Additionally, the type of traded commodities changed: mass-consumption goods gained advantage over luxury articles. ${ }^{371}$ In the course of trade exchange, the countries of the Baltic region - Poland, Prussia, Lithuania, Brandenburg, and Pomerania predominantly exported raw materials and agricultural products: grain, hemp, flax, wood, tar, birch tar, leather, and fur. At the same time, they imported highly processed craft products, particularly woolen cloth, textile goods, and luxury articles from Western Europe. ${ }^{372}$ The more advanced development of Western Europe forced a specific type of economic ties and consolidated the backward economic structure of Central-European countries:

The West underwent transformations, which exerted a considerable influence on the developmental path of Eastern Europe and caused its economy to gain a number of specific features. The structure of demand imposed by the western countries directed the countries of the Baltic region toward a path of unilateral development of production of raw materials and grain. ${ }^{373}$

A so-called price revolution of the 16th century was an additional factor consolidating this type of economic exchange. In the course of the 16th century, prices increased from four to seven times on average (annual increase amounted to around 2-3 \%). ${ }^{374}$ The above phenomenon brought about an uneven increase in prices - higher for agricultural and animal produce, and lower for craft products. The price revolution strengthened the agricultural structure of EasternEuropean countries and the monopolistic position of the nobility because the same amount of grain could be sold for a greater number of craft products. ${ }^{375}$

371 Zsigmond Pal Pach, The Role of East-Central Europe in International Trade (16th and 17th Centuries) (Budapeszt: Akademia Kiadò, 1970), pp. 218-220.

372 Marian Małowist, “Z zagadnień popytu na produkty krajów nadbałtyckich w Europie zachodniej w XVI wieku," Przegląd Historyczny, Vol. 50 (1959), p. 720; Antoni Mączak and Henryk Samsonowicz, "Z zagadnień genezy rynku europejskiego: strefa bałtycka," Przeglad Historyczny, Vol. 55 (1964), p. 201.

373 Antoni, Mączak, U źródeł nowoczesnej gospodarki europejskiej (Warszawa: PWN, 1967), p. 12.

374 Helmut George Koenigsberger and George L. Mosse, Europe in the Sixteenth Century (New York: Pearson, 1968), pp. 22-23.

375 Cf. Stanisław Hoszowski, "Rewolucja cen w środkowej Europie w XVI i XVII w.," Kwartalnik Historyczny, Vol. 68 (1961), p. 308; Marian Małowist, "Polska a przewrót cen w Europie w XVI i XVII w.”, Kwartalnik Historyczny, Vol. 68 (1961), pp. 315320; Miroslav Hroch and Josef Petran, "Europejska gospodarka i polityka XVI i XVII w.: kryzys czy regres," Przeglad Historyczny, Vol. 55 (1964), pp. 5-7. 
The above-mentioned factors led to an urbanization crisis, which affected the Central-European countries under study at various times. The first symptoms of the crisis were visible in Hungary at the turn of the 15th and the 16th centuries. Bohemian towns were afflicted with the crisis in the second half of the 16th century; in Poland, the urban sector suffered a crisis at the turn of the 16th and the 17 th centuries. ${ }^{376}$

One of the most fundamental historical observations is the acknowledgement of the underdevelopment of the urban sphere in Central-European countries. However, an explanation of this phenomenon in presented somehow ambiguously. According to the model of feudal economy in $\mathrm{n}-\mathrm{Mhm}$, in the final stadium of the phase of the increase of the alienation of labor, the growth of productive forces leads to an emergence of a separate sphere of production, a process, which, in Western Europe, resulted in the rise and development of towns. However, it is noteworthy that the emergence of the new sphere of production did not necessarily result in the development of urban economy. The new sphere of production could have existed in the same territorial and institutional framework as the old one.

Following from this, towns were a universal phenomenon. ${ }^{377}$ Towns existed in Chinese, Indian, and Islamic civilizations, which arose in accordance with other social dependencies than did European societies. To be sure, class factors influenced the character of the evolution of towns. However, class factors are responsible for only part of the nature of this phenomenon. I would argue that its more significant part could be explained with civilizational factors. Nonetheless, let us consider how much could be interpreted from the viewpoint of the $\mathrm{n}-\mathrm{Mhm}$ - a theory focused predominantly on class aspects of history (economic, but also political and cultural).

The urban sector evolved in the two parts of Europe non-simultaneously earlier in the West (in the 10th and the 11th centuries) and later in Central Europe (at the turn of the 12th and the 13th centuries). This difference resulted from the unevenly technological growth. The West underwent a technological progress earlier, due to the population crisis. ${ }^{378}$ Technological advancement was

376 Maria Bogucka, "Miasta Europy środkowej w XIV-XVII w. Problemy rozwoju," Roczniki Dziejów Społecznych i Gospodarczych, Vol. 47 (1981), p. 7.

377 Cf. Henryk Samsonowicz, Życie miasta średniowiecznego (Warszawa: PWN, 1970), pp. 15-16; Robert J. Holton, Cities, Capitalism and Civilization (London: Allen Unwin, 1986), pp. 118-140.

378 Lynn White, Medieval Technology and Social Change (Oxford: Oxford University Press, 1962), p. 53. 
introduced to Central Europe from the outside. The fact that towns emerged in the two parts of the continent non-simultaneously affected the nature of trade ties between Western and Central Europe. The products of Central-European craftsmanship were introduced to the European market later and, as a result, had to compete with already present and more advanced Western-European craftsmanship. The barrier of a later start has never been overcome. Consequently, since the late medieval age, individual Central-European societies have specialized in exporting raw materials, minerals, and agricultural products. In turn, Western Europe, in turn, exported highly processed craftsmanship - and, subsequently, industrial products - to Central-European countries.

The rise and development of towns took place in the two parts of Europe during different phases of social ties between owners and direct producers of the agrarian economic system. In Western Europe the urban sphere originated in the phase of the increased alienation of labor. Initially, the alienation of labor was lower in the urban sphere of production, in comparison to the situation in agriculture, and it brought about a mass migration from the old sphere of production (rural) to the new one (urban). Hence, the process of emergence of the urban sphere unfolded in opposition to the class of owners of the old sphere of production (feudal lords). In contrast, in Central Europe, the urban sphere emerged in the period of the decreased alienation of labor and prevailing class peace. In this stadium of social development, direct producers did not have to resort to migration to towns in order to achieve a higher income. For this reason, migration of the native workforce to towns was less substantial and the urban population in Central Europe was smaller. Moreover, there were a considerable percentage of German and Jewish populations in Central-European towns (Jewish settlement in Poland begun in the 13th and the 14th centuries, following persecutions in Western Europe). In some layers (the patriciate), the population of foreign origin gained absolute dominance over the native population.

To recapitulate the above considerations we could state that the underdevelopment of the urban sphere in Central Europe was a consequence of a late emergence of towns in this region. The delay was responsible for establishing a unilateral trade exchange between Western and Central Europe. Additionally, Central-European towns emerged in the phase of class peace prevailing in the rural economic system. This fact hindered acquisition of the required size of workforce. A low level of population density in respective Central-European societies additionally deepened the above problems.

The economic weakness of the urban sphere of production was reflected in a lesser social importance of burghers in comparison to their social position $\mathrm{n}$ Western Europe. In her studies on the social activity of Central-European 
burghers, Maria Bogucka adopts E. Lousse's categories of the three levels of estate awareness. ${ }^{379}$ This is said to be composed of: (1) the ability to form occasional coalitions of defensive nature, (2) the ability to create permanent alliances in defense of common interests, (3) the ability to force estate privileges. According to Bogucka, Polish burghers achieved the first level of estate awareness. They were capable of forming temporary confederations to protect their interests and to participate in the confederations of the nobility. This capability was characteristic of Polish towns only until the middle of the 15th century. Since the second half of the 15th century, they have not even formed occasional, defensive confederations. In contrast, Bohemian and Hungarian merchants reached the second stage of estate awareness. Burghers in those countries participated in the Hussite Revolution and Reformation, and joined the nobility in the struggle against the Habsburgs; also, they had the right to nominate its representatives to Parliament. However, the basic feature of political systems in Hungary, Bohemia and Poland was the supremacy of the nobility in representative institutions. That advantage allowed the nobility to influence and control the enactment of law and the activity of the state, which served the interests of the domineering social class. As early as in the first half of the 15th century (in 1437 in Bohemia, in 1496 in Poland, and in 1514 in Hungary), they issued legal acts against the migration of peasants. State regulations, which limited the freedom of the peasantry, were considerably easier to enforce due to the weakness of burghers and the insignificant role of the urban labor market. According to the comparison made by Arcadius Kahan:

The role of the cities was also different in the Western and Eastern Europe. While in the West most of the cities developed into corporate bodies with charters guaranteeing the freedom of the city-dwellers and therefore sometimes served as an escape route from serfdom, in Eastern Europe many of the cities did not possess such charters, or were owned by large serf owners and could not provide the escape valve for serfs. ${ }^{380}$

Political domination of Central-European nobility enabled introduction of serfdom and of restrictions to the development of the urban sphere. The above factors, together with a shortage of workforce, have contributed to the distinctiveness of Central Europe. A prerequisite to understanding the causes of the emergence of a manorial-serf economy is predominantly an analysis of social relations between the class of owners and the direct producers of the old sphere

379 Bogucka, “Miasta Europy środkowej”, pp. 22-23.

380 Arcadius Kahan, "Notes on Serfdom in Western and Eastern Europe," The Journal of Economic History, Vol 33 (1973), p. 98. 
of production (nobility versus peasantry). The relations between owners and direct producers were considerably influenced by a deficiency of manpower. In agreement with the almost unanimous opinion of historians, the introduction of the second serfdom in Central Europe was forced by a shortage of workforce. Owners responded to the increasing demand for manpower of direct producers with bounding peasants to land. The introduction of serfdom was supposed to prevent escapes and ensure stability of manpower. According to Longworth, for instance, serfdom was brought about only by economic factors:

Rising prices certainly encouraged landlords and even some peasants to sell more grain for cash but the readiest means of increasing production at that time was to take more land under cultivation, and there was still plenty of wasteland that could be cleared and ploughed. On the other hand there was scarcity of people to do the work. In England the population shortage following the Black Death in the fourteenth century had had the effect of freeing peasants; in Poland, Prussia, Russia, and the Habsburg territories, on the other hand, the relative scarcity of labor served to complete their subjection and intensify their exploitation. ${ }^{381}$

Meanwhile, according to model III of an economic society with a shortage of manpower, the class of owners is forced to considerably mitigate exploitation. In a purely economic society - a society deprived of the influence of the disposers of centralized means of coercion and the disposers of means of indoctrination, institutions of economic life and social consciousness organizing collective thinking on socio-economic life - an alienation of labor can rise to a certain level. If this level is attained, instances of escapes of direct producers effectively disintegrates the production process in a way that owners are forced to grant a number of concessions in order to ensure continuity of the production process. To end the migration of workforce, they introduce amendments to the method of division of live product or revise the rules of ownership. Following from this, in a purely economic society with a shortage of manpower, a long-lasting declassation of direct producers is impossible. However, this is the direction of evolution in the abstract reality of the model. In a historical reality, a combined impact of a cascade of factors overbalanced the developmental trends outlined in model III. Among these factors were not only the relations between the nobility and burghers but also those between the nobility and state authorities. If the nobility was successful in securing its interests in both networks of social relations, it guaranteed economic exploitation of the peasantry. State authorities, subjected to the interests of the nobility, withdrew from regulating economic

381 Longworth, The Making of Eastern Europe, p. 190. 
relations in the rural economic system. As a result, the nobility gained additional instruments of state coercion, which could have been used against direct producers. Additionally, the weak position of the authorities influenced relations between burghers and the nobility. The advantage of the nobility over burghers increased when the former gained the ability to employ instruments of state coercion. When the development of urban economy was limited, competitiveness of that sphere of production dropped, which, in turn, indirectly strengthened the position of the nobility against the peasantry. A superior position of the nobility in one social subsystem depended on its superior position in the other, and vice versa.

In that configuration of factors that were constantly present in the cascade of European differentiation, the shortage of manpower played various functions at different stages of social development. When nobility could not resort to means of coercion used by the centralized state apparatus (the period of feudal division), the scarcity of manpower extorted from the nobility concessions granted to the direct producers. However, when, the nobility succeeded in subjugating the state and limiting the influence of the urban sphere (its weakness was among other thing conditioned by a low level of population density), that factor stimulated the restoration of serfdom and a considerable increase of exploitation. The core of the cascade of the European differentiation present in each of the three Central-European societies under study, can be demonstrated graphically in the following way:

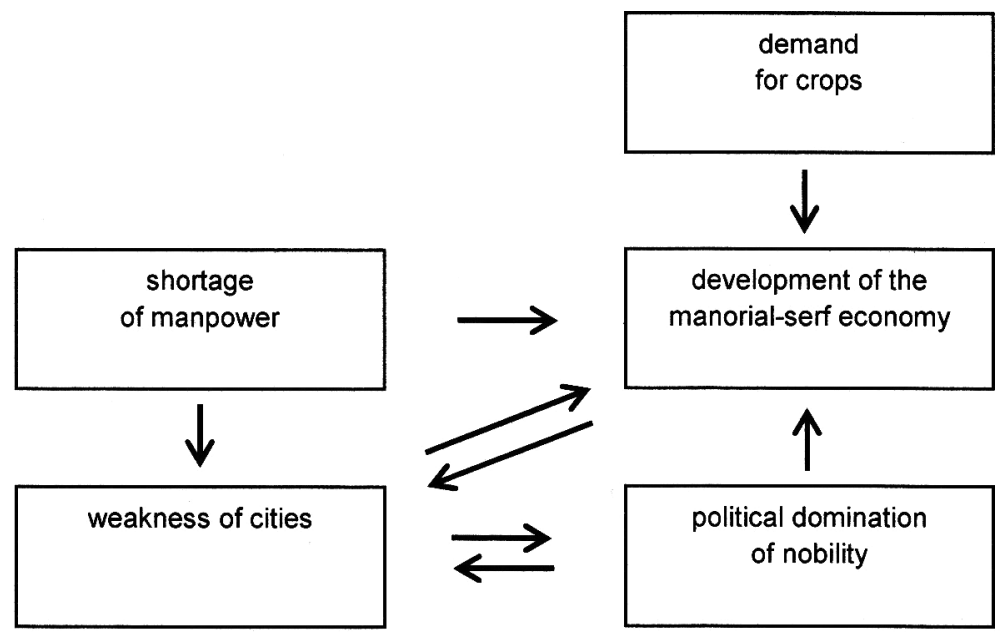

Fig. 23: The core of the cascade of European differentiation. 
At this scheme, the scarce supply of manpower tempered the increase of the level of alienation of labor in the rural sector of production. However, the improvement in the economic situation of peasantry hindered the growth of cities and at the same time made it difficult to obtain sufficient manpower. The underdevelopment of towns enabled the increase of the alienation of labor in the agricultural sector of the economy and allowed the nobility to subordinate the state to its interests. As a result, the nobility could implement state means for further weakening of the position of towns and intensification of the exploitation of the rural sector of economy. The decline of peasants' income brought about the decrease of the purchasing power of the largest social group and blocked the developmental perspectives of the urban sphere of production. An additional factor, which played the role of a catalyst of social changes, was the demand for grain, both domestic and foreign, which accelerated the rise and the accumulation of the cascade of European differentiation.

The distinctive developmental path of Central Europe was not brought about by a single factor, but was a consequence of a multi-factor influence. At a certain moment, a gradual accumulation of these variables predominated over the impact of basic developmental mechanisms outlined in model III of an economic society. In contrast, Western-European societies evolved in accordance with them (the plague epidemic brought about a temporary shortage of manpower) because such a number of counteractive factors did not appear there. Many historians, who deal with the history of that region, share intuitions proving that the developmental characteristics of Central Europe were a consequence of a multi-factor influence. For example, Peter Longworth expresses the following opinion:

And there was a plethora of other factors which intervened at various point with varying intensity to influence the course things took. Linguistic differences, for example, sometimes fed into religious and political struggles; and social classes sometimes gained and lost constitutional rights according to the religion they embraced at particular moment. Low population density in Poland-Lithuania contributed to the enserfment of the peasant. [...] The Baltic grain boom had helped to promote serfdom, yet the end of the boom around the turn of the century served not to remove serfdom but entrench it. [...] The interactions of circumstances and catalysts that shaped Eastern Europe in the period from 1526 to 1648 far exceeded in complexity the most complicated transmutation process in any alchemist's laboratory. ${ }^{382}$

382 Longworth, The Making of Eastern Europe, p. 183. 
Within the cascade of European differentiation one can distinguish factors, which form its core, and those, which characterize only some developmental paths of particular societies. The countries discussed above also had a different pace of growth of the cascade of European distinctiveness. It is demonstrated by an uneven development of a manorial-serf economy in each of the three societies. In Poland, a manorial-serf economy appeared in the course of the 16th century, in Hungary in the second half of that century, and in Bohemia as late as in the 17 th century. The presence of additional factors proving developmental characteristics of each of the Central-European societies and various pace of the growth of the cascade of European differentiation allows discerning regional variants, which shaped the distinctive nature of development, namely the Polish, Hungarian, and Bohemian variants.

Except for the division of factors into those common to all Central-European societies and those specific to particular developmental paths, one can offer an alternative division by distinguish the following factors:

(1) internal - determining the development of social relations in each of the three distinguished subsystems: between the class of owners and the class of direct producers of the rural sector of the economy, between the owners of the old and the new sphere of production, and between the class of owners of the old sphere of production and the class of rulers;

(2) external - of economic type; this type of factors includes, for instance, high demand for agricultural products in Western Europe. This demand enforced the economic position of the owners of the old sphere of production against other social classes;

(3) external - of political type; this type of factors includes political conquest and war devastations, which disrupted the balance between social classes in a given country.

The shortage of manpower plays a key role in this conceptual scheme. It was the earliest factor to appear from the cascade of European differentiation, its impact lasted throughout the entire historical period under study and this impact was present in each of the historical societies under study. Let us now analyze separate regional variants of the cascade of European differentiation: Polish, Hungarian and Bohemian.

\subsection{The Polish Variant}

Grand landownership arose in consequence of the disintegration of the Ius Ducale in the 12th and the 13th centuries. According to model III of an economic 
society, the low level of population density - in the 10th century Poland was populated by ca. 1 million people - forced the class of owners to grant economic concessions to the peasantry. The developing grand feudal ownership strove to increase its income through the development of German colonization and settlement with on German Law, which also improved the wealth of the native peasantry. Economic changes were already in progress and contributed to the development of an urban economy at the turn of the 13th century. According to model IV of feudal society, the above processes can be interpreted as an emergence of the division of the economy into two spheres of production: agriculture and craft. Changes in the structure of the economic system were accompanied by transformations in the structure of political life - at the beginning of the 14th century, after state fragmentation, the Polish state experienced a unification. In light of the political theory of $\mathrm{n}-\mathrm{Mhm}$, centralization of state authority brought about an increase of state control. One of the sources, which allowed the class of owners to increase their scope of social impact, was a division of the class of owners into two categories: knighthood (owners of the old sphere of production) and burghers (owners of the new sphere of production).

Since the end of the 14th century, there has been a counter trend in the relations between a particular fraction of the civil class (owners of the old sphere of production) and the class of rulers - the sphere of political autonomy of a certain group of citizens increased and the sphere of state control decreased. The process can be best traced with reference to the example of the development of the nobility's privileges and the formation of the system of democracy of nobility. As early as in 1372, the Polish king reduced tax paid by the nobility from 14 grosz to 2 grosz from 1 tan (ca. 15 ha) and announced that he would not impose any new taxes without the consent of the nobility. The privilege of 1422 forbade confiscation of estates owned by the nobility, and another one of 1433 prohibited imprisonment of a nobleman without a binding court order. Thus, the initial privileges protected civil rights and economic property. In the second half of the 15th century, the principles of the system of the democracy of nobility were formed. In 1454 in Nieszawa, Casimir Jagiellonian accepted the principle that all significant decisions - such as proclaiming new rights and summoning a mass levy - required consent from the nobility, expressed at regional assemblies (sejmiki). General Sejm (Polish parliament), composed of the delegates of the nobility chosen at the regional assemblies, was constituted at the end of the 15th century. In 1505, that new institution was reinforced by the Nihil Novi law, which prohibited the king from establishing new laws without the consent of the Chamber of Deputies. Subsequently, the position of the nobility was reinforced at the expense of the prerogatives of central authorities after the extinction of 
the Jagiellon dynasty and the introduction of the elective throne. Every newly elected king had to sign the so-called Henrician Articles and the Pacta Conventa. The Henrician Articles were a collection of fundamental laws, which formed the backbone of the political system of the Polish-Lithuanian Commonwealth. They guaranteed the elective succession of the throne, religious tolerance, the duty to call the Sejm for 6 weeks at least once every two years and prohibited levying new taxes without the consent of the Chamber of Deputies. Should these provisions be infringed on, the nobility would have the right to refuse obedience to the King.

In the 17th century, the process of decentralization of the system of the PolishLithuanian Commonwealth was initiated. In the face of the growing paralysis of central state institutions - since 1648 the resolutions of the Sejm had to be unanimous by virtue of the liberum veto, more and more competencies concentrated in local institutions, at the level of regional assemblies. Those changes in the functioning of the system of the Polish Republic were associated with changes in the estate of the nobility - the declining importance of the middle nobility, which supported the Executionist movement in the 16th century, and the rise of the significance of the magnates. The emergence of the oligarchy of magnates was the social element, which supported transformations of the system.

The above situation was a result of the same factors, as in other CentralEuropean countries. Polish towns came to existence later than Western-European towns, in a different phase of social relations between owners and direct producers of the old sphere of production (a decrease of the alienation of labor), in comparison to towns in a typical western society. In Poland, similarly to the situation in other Central-European countries, towns formed in the period of the decreasing alienation of labor in the rural production sector. This decrease of the alienation of labor created obstacles for achieving an optimal level of manpower because the peasantry was not forced to migrate to towns in order to achieve higher income. Western-European towns did not experience such difficulties because they evolved in the phase of the increasing alienation of labor in the old sphere of production. Initially the level of alienation of labor in the new sphere of production was lower than in the old one; thus, direct producers migrated to the new sphere of production on a massive scale. As a result, Western-European towns could develop more dynamically.

Apart from the above-listed factors characteristic for the entire region under study, cascade factors, which range was limited to the Polish territory, have also played a certain role in the consolidation of the weakness of towns.

The urban patriciate, predominantly of German origin, was not interested in uniting the Polish state by the Piast dynasty in the 13th and the 14th centuries. In 
that period, patriciate representatives supported the idea of uniting Polish lands with the Bohemian or Hungarian states. Preference of the above political option was affected by vivid trade contacts with the European countries situated in the south of Poland. ${ }^{383}$ Burgher elites repeated their faulty policy. When the political foundations of the Polish-Lithuanian Commonwealth were being created, burghers were not interested in participating in representative bodies, which were dominated by the nobility because they preferred to negotiate directly with the king in matters of concern to them. ${ }^{384}$ Political weakness of the inhabitants of towns also resulted from the structure of the burgher estate. Poland did not have burgher elites with financial potential allowing it to conduct an effective policy. ${ }^{385}$ Moreover, in Poland, because of the decentralization of power and the enormous significance of the nobility, there were no significant reasons for an alliance between the throne and burghers. As Antoni Mączak maintains:

In order to engage in the matters of the state, towns required a strong impulse. According to the Western model, it might have been an alliance between burgher elites and the state apparatus. In most monarchies, this apparatus expanded and rulers sought both loyal and professional officials. In Poland, the self-government of the nobility did not offer satisfactory conditions: the state apparatus did not expand and there was no place in it for the plebeians. ${ }^{386}$

According to Maczak, the decentralized political system of the Polish-Lithuanian Commonwealth, which blocked the careers of burgher elites, was brought about by territorial vastness manifested in the time it took for information to be disseminated, and the privileges of the nobility, which eliminated the rise of the king's absolutism:

It could be put as follows: the space to be controlled by the authority was too vast for the Polish-Lithuanian Commonwealth to function efficiently as a state while preserving the privileges of the nobility. Actual decentralization was a consequence of many factors systemic (privileges), technical (poor ties of social communication) and finally socioeconomic (concentration of property). The authority of magnates understood as a

383 Bogucka, Samsonowicz, Dzieje miast, p. 293.

384 Andrzej Wyczański, “The System of Power in Poland, 1370-1648," in: Central Europe in Transition. From the Fourteenth to the Seventeenth Century, eds. Peter Burke, Antoni Mączak and Henryk Samsonowicz (Cambridge: Cambridge University Press, 1985), pp. 140-153.

385 Antoni Mączak, “Jedyna i nieporównywalna? Kwestia odrębności Rzeczypospolitej w Europie XVI-XVII wieku," Kwartalnik Historyczny, Vol. 100 (1993), p. 124.

386 Mączak, “Jedyna i nieporównywalna?”, pp. 124-125. 
counterbalance to the monarchy was in a certain sense a function of the territorial size of state. ${ }^{387}$

The domination of the class of rulers (organized into a state) by the owners of the old sector of economy (nobility), accompanied by initial weakness of the new sphere of production, was self-perpetuating in nature. The political authority controlled by the nobility was turning into a tool that regulated the urban sphere of production. This regulation was performed for the social interests of the nobility. The state control of the urban sector limited its developmental potential, which further undermined social balance between the nobility and burghers. This subsequently restricted the room for manoeuvre of the political authority and led to yet more evident subordination of the state to the social interests of the nobility. As a result, the nobility, which had at its disposal the means of production but also subjected those in control of the means of coercion, was able to increasingly enforce their interests in the public life.

Symptoms of anti-municipal policy were visible at the dawn of the 15th century. ${ }^{388}$ In 1496, a ban was issued prohibiting the purchase of land by burghers. Moreover, the townspeople were removed from higher church and state offices: including land, crown and court offices, and the office of a county administrator (starostwo). In 1496 and 1509, after the nobility was exempted from customs duties, the entire burden of paying duties was imposed on burghers. In contrast, the nobility could import and export any quantity of commodities duty-free. In 1538, there was a failed attempt at abolishing the guilds. At the same time, political authority opened the domestic market to foreign merchants. Until that moment, foreign merchants could run their economic activity only as wholesalers. Simultaneously, in 1565, the local burghers were forbidden to leave Poland to engage in foreign trade. However, in fact, the above ban was not obeyed. In the middle of the 16th century, voivode fees were introduced administratively fixed price rates for town products set by a voivode (wojewoda). It is worth mentioning that a free market shaped the price of grain, which was a basic serfdom-based farm product. Another factor, which weakened the position of towns, were the so-called jurydyki. They were properties of the nobility within towns, which were not subject to urban jurisdiction. Very often, the nobles settled craftsmen there to carry out production beyond guild regulations. The control over economic life by state authorities was exercised solely in the nobility's

387 Antoni Mączak, Klientela. Nieformalne systemy władzy w Polsce i w Europie XVI-XVII w. (Warszawa: Semper, 1994), p. 142.

388 Bogucka, Samsonowicz, Dzieje miast, pp. 321-328. 
interests. That social group also forced burghers out of the most profitable activities, for instance, in the 16 th century ca. $70 \%$ of rafting down the Vistula river was controlled by the nobility.

In the following centuries the degradation of burghers deepened even more. In the 17 th and the 18 th centuries, they were not allowed to take up any of remunerated state offices or to hold church functions. They were also deprived of the right to serve in the army, which was the only way for one's elevation to the rank of the nobility. At the same time, the judicial autonomy and urban self-government were practically abolished. The history of the urban sphere in the Polish -Lithuanian Commonwealth was, as Maria Bogucka and Henryk Samsonowicz maintain, entirely incomparable to the development of towns in Western Europe:

The main trait of the modern epoch was a rapid emancipation of burghers and their development, which brought about fundamental changes in class, economic and hierarchical arrangements of contemporary societies. Against this background, the Polish Republic was an exceptional terrain: the monopolization of social, economic, and political life by the nobility reached the level that was unparalleled anywhere else. Many researchers also point out that the particular situation of our towns and their inhabitants from the 16th to the 18th century was one of the principal factors to have caused unfavorable peculiarities and a dangerous distortion of the entire Polish historical process in that epoch. ${ }^{389}$

Social consequences of that developmental distortion brought about a weakening of state authority. As Samsonowicz remarks:

In almost all places where the urban population played the same or insubstantially less important role than the nobility in the life of the country, due to the privileges and real financial opportunities, and where antagonistic interests were involved among various professional groups, there the king's authority grew as a mediator of conflict between estates. There, strong modern states were also formed. (...) The position of the state was undermined by the weakness of any of social forces. ${ }^{390}$

The subordination of political authorities to the nobility brought two-fold consequences. First, the social role of burghers and of the urban labor market were limited. Second, the impairment of burghers' social position allowed the use of tools of state regulation to increase income to maximum in the own sector of economy. The weakness of burghers and the urban sphere of production was essential not only for social relations between the state and nobility but also for economic relations between the nobility and the peasantry.

389 Bogucka, Samsonowicz, Dzieje miast, p. 328.

390 Samsonowicz, Życie miasta średniowiecznego, p. 146. 
In a typical Western society, the urban sphere of production created an alternative labor market. As long as a low level of alienation of labor prevailed in that sector of economy, it enforced, in fear of the migration of the peasantry to towns, a similarly low level of alienation of labor in agriculture. The crisis of the urban sphere at the turn of the 15th and the 16th centuries in the modern Polish economy diminished the impact of the alternative labor market and allowed the nobility to impose ever-greater burdens on the peasantry.

In a purely economic society, the shortage of manpower is a factor curbing the growth of the alienation of labor. In fear of direct producers escaping to owners who offer more advantageous working conditions, the nobility granted concessions. Owners benefit more from exploiting a larger number of producers in a milder way, than from exploiting a smaller number of producers in a more severe way. However, the above mechanisms only apply to a purely economic society deprived of the class of rulers. In contrast, in a society with a political authority, which is subordinated to ownership, the factor of shortage of manpower is too weak to enforce a low level of alienation of labor. The class of owners may use state control to maximize profit. One of the consequences of state intervention may be, for instance, a limitation of the freedom to move, which, in turn, under the conditions of shortage of manpower, hinders the increase of exploitation. Following from this, an increase of the alienation of labor under the conditions of shortage of workforce is possible only in a society with an underdeveloped urban sphere and a political authority subordinated to the class of owners.

An increase of the alienation of labor in the rural sphere took place in the organizational and institutional framework of a manorial-serf economy experienced. However, reinforcement of serfdom was a prerequisite for the development of the villein service. The Wiślicki Statute proclaimed by Casimir the Great imposed restrictions on leaving the village without the lord's consent to just one peasant family annually. The Statute for Greater Poland imposed additional requirements on leaving the farm in good condition. As Leonid Żytkowicz points out, that was only an introduction to serfdom. The development of serfdom should not be linked with an increase in the villein service, which was then insignificant, as it amounted to a dozen or so days annually. The binding of peasants to land was caused by that fact that:

grand ownership constantly struggled with the deficit of settlers indispensable for the management of the estate (let us remember that we are discussing the period of rent, and not the manorial economy). In a reversed situation, if there were a lot of candidates to settle on the lord's land, it would probably not come to the growth of glaebae adscriptio. 
It was in the interest of the feudal class to retain the settler in the country, in order to secure the feudal lord's income in the form of tributes and rents. ${ }^{391}$

The next stage in limitation of instances of escapes and migrations of the peasantry occurred in the second half of the 15th century. The Piotrków Sejm in 1496 limited the right to leave the village, subject to the lord's consent, to one family annually. Only one son, providing he was not the only son, could leave the village. The Sejm provisions from 1501-1511 additionally tightened those regulations by extending them to include the children of peasants' families. The regulations were supposed to protect the nobility against the desertion of peasants and the danger of depopulation of the country. ${ }^{392}$

The above process of imposition of serfdom was accompanied by another, independent process of accumulation of lands within institutional framework of the noble's demesne. It is assumed that the manors of the nobility descended from the own farms of ordinary knighthood (praedium militarae), which were intended for subsistence farming. ${ }^{393}$ With the rise of the commodity-monetary economy, the output of own farms shifted toward commercial production. The acreage of the farms was enlarged at the expense of fallow, uncultivated lands (so-called empty łan) and buying out village headmen's manors (folwarki soltysie). ${ }^{394}$ Another way to expand a noble's demesne was through acquiring a better land farmed by the peasantry in exchange for lower-quality land (rugi). ${ }^{395}$ In total, in the 16th century, the own farm of the manor owner covered around $25 \%$ of arable land used by the village, which amounted to about 3.5 tan (ca. $60 \mathrm{ha}) .{ }^{396}$

Compulsory serf labor (pańszczyzna) was the main burden imposed on peasant farms. ${ }^{397}$ However, peasants had to perform other kinds of obligations

391 Leonid Żytkowicz, "Przesłanki i rozwój przytwierdzenia do gleby ludności wiejskiej w Polsce - poł. XIV w. - początek XVI w.," Przegląd Historyczny, Vol. 75 (1984), p. 6.

392 Żytkowicz, "Przesłanki i rozwój”, p. 20.

393 Cf. Andrzej Wyczański, Studia nad folwarkiem szlacheckim w Polsce w latach 15001580 (Warszawa: PWN, 1960), pp. 27-36; Rusiński, “Drogi rozwojowe,” p. 622; Roman Grodecki, "Początki gospodarki folwarcznej w Polsce," in: Studia z dziejów kultury polskiej, eds. Henryk Barycz and Jan Hulewicz (Warszawa: Gebethner i Wolff, 1947), p. 58.

394 Wyczański, Studia nad folwarkiem, pp. 50-54; Jan Rutkowski, Studia $z$ dziejów wsi polskiej w XVI-XVIII w. (Warszawa: PWN, 1956), pp. 65-81.

395 Rusiński, “Rugi chłopskie,” p. 30.

396 Andrzej Wyczański, Wieś polskiego Odrodzenia (Warszawa: PWN, 1969), p. 83.

397 Wyczański, Wieś, pp. 95-101. 
apart from mentioned earlier villein service. One of them was rent of 30-60 grosz paid from one peasant $\tan$ ( $\tan k$ kmiecy). Apart from pecuniary performances, peasants were obliged to bring tributes in kind. Among them were sepy, equal to 1-6 bushels of oat or 1-2 bushels of rye or wheat from one peasant łan. Moreover, peasants provided certain amounts of eggs, poultry, and cheese. Apart from permanent services, there were also occasional obligations, such as: powaby, which were additional labor services usually lasting a few days (4) required at the time of an extraordinary accumulation of work, or przewozy in a form of transporting various goods to specified places, most often a point of rafting grain or a mill. At the end of the 16th century, stróża became popular - an obligation to keep watch over the manor at night.

The fundamental peasant service, which guaranteed an economic profitability of a manor, was compulsory serf labor. In the 16th century, there was a number of different types of this villein service. One of them was unlimited serf labor, which length and frequency was wholly at the discretion of the manor's owner. In the period of the emergence of manorial farms, this kind of villein service was already fading. Another type of compulsory serf labor usually found in church properties was jutrznia. A peasant (kmieć) providing this service had to perform the complete work associated with cultivation of a given parcel of land. The most popular form of compulsory serf labor was service defined annually or weekly. It determined the number of working days in a week or in a year. Kmiecie peasants who owned a farm composed of 1 full łan - performed work using draught animals, and zagrodnicy performed it on foot. ${ }^{398}$ According to Andrzej Wyczański's calculations, in the 16th century, in a manorial farm of an average acreage that belonged to a nobleman, the compulsory serf labor was not the only kind of labor. The nobility additionally used hired labor. In the general balance of manpower, villein service accounted for ca. $41.2 \%$ of workdays, whereas hired labor for $58.8 \%$. A considerable share of hired labor resulted from the fact that workmen were usually hired for the period of 300 full days during a year, whereas peasants who possessed their own farms worked less, depending on the time of the year, from 1 to 4 days weekly. However, the larger the acreage of a manor and the number of villages, the higher the share of the villein service. The profitability of manorial production relied on the possibility of using this kind of compulsory labor. Compulsory serf labor was also the main burden imposed on the peasantry, and its scope has gradually increased in the course of the 16th century. In 1520, the Bydgoszcz-Torun Statutes set the serf labor load at 1 day per week per

398 Wyczański, Wieś, pp. 136-138. 
1 tan of peasant land. The real increase in villein service that occurred later was not reflected in the provisions of the Sejm. Based on Wyczański's calculations, it grew from 1 to 3-4 days a week in the course of the 16th century.

The nobility demesne specialized in cultivation of grain for sale. According to Wyczański's calculations, around $60 \%$ of the manorial production was sold on the market, both domestic and foreign. ${ }^{399}$ The demand for Polish grain had persisted since the late Middle Ages, however, the increase in the prices of agricultural goods on the European market from the 16th century onwards provided the impulse to develop export. ${ }^{400}$ Between the first and the eighth decade of the 16 th century, the prices for four grains grew by average $292 \%$, compared with $166 \%$ for animal products and only $45 \%$ for craft products. ${ }^{401}$ The export of Polish grain was a response to the above shift in prices. Annual sales abroad amounted to ca. 100,000 tons of grain ${ }^{402}$. That accounted for $2.5 \%$ of the total production of grain in Poland. ${ }^{403}$

The development of a manorial-serf economy based on villein service brought about social consequences for the economic situation of direct producers of the rural economic system and for the developmental prospects of the urban sector. The increase of villein service caused a decline in the productivity of peasant farms. That, in turn, brought about a growing naturalization of the peasant economy. Peasants, after performing their villein service, could produce enough to support themselves and their draught animals, which were used in fieldwork. Additionally, the decline in peasant production limited market contacts of the peasantry with a town. A peasant was not only a seller of his own products but also a purchaser of craft goods. The drop in peasant income undermined the foundations of domestic craft production. As a result, in the 17th and the 18th centuries, the urban sector of economy was reduced to a size regulated by the demand of direct producers from the rural sphere of production. The impact of

399 Wyczański, Studia nad folwarkiem, p. 60.

400 Grodecki, "Początki gospodarki folwarcznej," pp. 64-69.

401 Wyczański, Studia nad folwarkiem, pp. 222, 227-228.

402 Cf. overview in: Leonid Żytkowicz, "Trends of Agrarian Economy in Poland, Bohemia and Hungary from the Middle of the Fifteenth to the Middle of the Seventeenth Century," in: Central Europe in Transition. From the Fourteenth to the Seventeenth Century, ed. Peter Burke, Antoni Mączak and Henryk Samsonowicz (Cambridge: Cambridge University Press, 1985), pp. 65-66.

403 Andrzej Wyczański, “Czy chłopu było źle w Polsce XVI wieku?," Kwartalnik Historyczny, Vol. 85 (1978), p. 628. 
factors in the Polish version of the cascade of developmental differentiation can be demonstrated graphically in the following way:

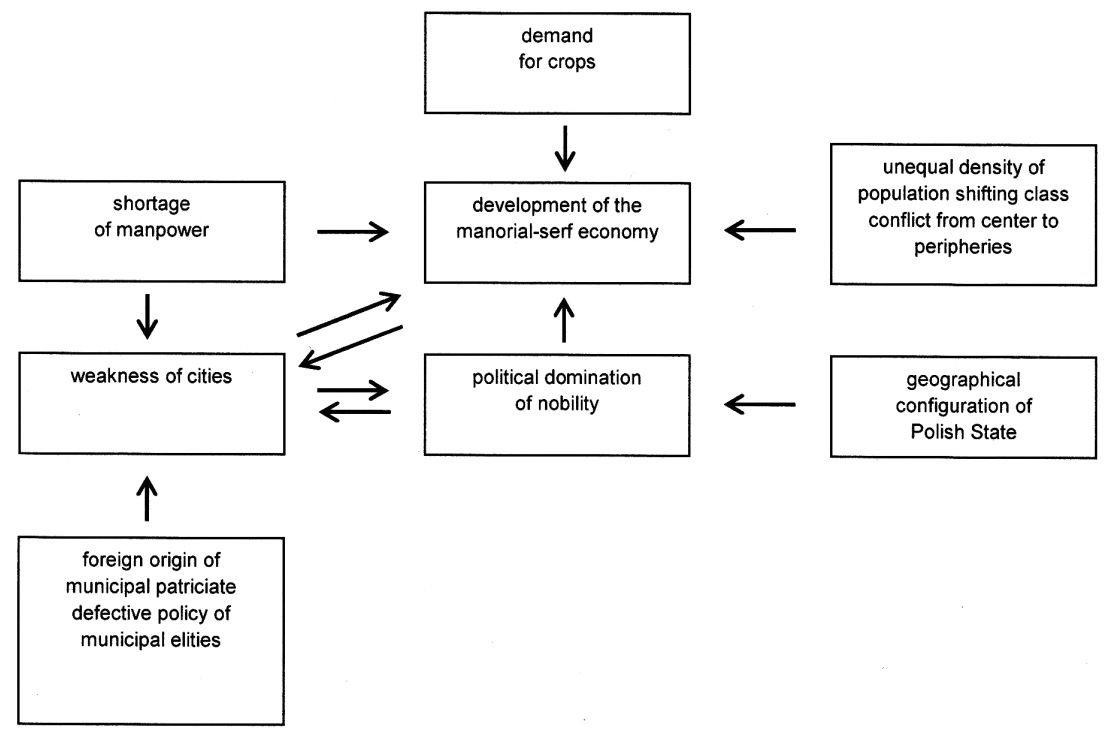

Fig. 24: The Polish variant of the cascade of developmental differentiation.

The peculiar feature of the socio-economic development of the PolishLithuanian Commonwealth was absence of peasant revolutions. Interestingly, considerable social revolutions were absent only from the rural sphere of production. In a number of Polish towns: Gdańsk, Elbląg, Królewiec (Kaliningrad), Cracow, and Lvov, common people protested against the patriciate in the first half of the 16th century in response to economic problems. Common people demanded abolishment of economic privileges of the patriciate, which held the highest power in towns, and control over the finances of the urban authorities. The strictly economic postulates included: abolishment of usury, monopoly and privileges of large commercial companies. The tensions were pacified with a reform of the municipal system. Apart from the two already existing self-governmental institutions, namely board and council, a third one was introduced - the so-called third order (trzeci ordynek) composed of the representatives of the common people. The second wave of protests took place at the turn of the 16th century in larger production centers. The social conflict between the associations of apprentices and the guild masters concerned solely the issue 
of pay. ${ }^{404}$ The protests ended as soon as masters agreed to higher salaries of the apprentices.

Larger social revolutions did not spread to the rural economic sector due to an array of external and internal factors. For instance, an increase in prices on agricultural products, which compensated for the drop of peasant income, brought about by the increase of villein service and other burdens. ${ }^{405}$ According to Wyczański's calculations, the real peasant income grew 3-4 times during the 16th century. An uneven increase in prices on agricultural and craft products brought about the improvement of the economic situation of the peasantry. ${ }^{406}$

The internal factors, which prevented the peasantry from starting a revolution, included a slow pace of development of serfdom and of the increase of compulsory serf labor. ${ }^{407}$ Noteworthy, the Polish-Lithuanian Commonwealth was characterized by an uneven population density. The country had demographic centers and peripheries. The crown lands had the population of around 20 people per square $\mathrm{km}$, and the Grand Duchy of Lithuania or Ukraine had the population of maximum 2 people per square $\mathrm{km}$. Migration from central terrains to peripheral terrains, where exploitation was respectively lower, grew with the increase of exploitation. The nobility succeeded in subordinating the state to its interests and begun using it to proclaim serfdom and to introduce an increase in villein service; however, the weakness of the state apparatus of the Polish-Lithuanian Commonwealth prevented any effective execution of these decisions. Let us now refer to Jan Rutkowski's view:

Polish state authorities insubstantially limited the power of lords over serfs, however the nobility could not fully benefit from the situation, particularly due to the low level of population density, which facilitated the position of the peasantry against the grand ownership. On the other hand, the weakness of state authorities prevented them from appropriately securing the interests of grand ownership. The above factors, namely the low level of population density and the weakness of state authorities, occasionally protected the interests of the peasantry to a much greater degree, than legislation designed to defend the peasantry in situation when state authorities were powerful enough to protect grand ownership against the "lawlessness" of the peasantry, but too weak to make sure that the legislation was abided. ${ }^{408}$

404 Bogucka, Samsonowicz, Dzieje miast, pp. 463, 477-488.

405 Małowist, Europa i jej ekspansja, p. 95.

406 Wyczański, “Czy chłopu,” p. 636.

407 Władysław Konopczyński, Dzieje Polski nowożytnej (Warszawa: PAX, 1986), p. 295.

408 Rutkowski, Wieś europejska, pp. 33-34. 
Under the conditions of low density of population, the peasantry used desertion to protect itself from the increase of exploitation. According to Wyczański:

A more effective way to hurt a nobleman [...] is migration of the peasantry. The most significant role of escapes was a form of class struggle. [...] The desertion of peasants from one landowner to another was effective because all landowners had a high demand on peasants, which led to a conflict between them.

$[\ldots]$

The mass character of desertion and the fact that it was relatively easy to carry out resulted in the fact that social meaning of migration was enormous. The escapes, or even fear of them was the principal factor, which curbed the increase of feudal burdens and which protected the peasantry against injustice and malpractice. It was the only factor, which was able to effectively limit the development of manorial farms, the impunity of lords and their officials, and to make it harder for them to take farms, tools, and property from peasants. ${ }^{409}$

The stream of peasant deserters headed toward Ukraine, and more particularly, the following provinces with a low level of population density, namely Volhynian, Kiev, and Bratslav provinces. Following the incorporation of the above-listed provinces to the Crown in 1569, they were subjected to intense German colonization. The peasantry was resettled there by magnates and guaranteed a long-lasting exemption from feudal burdens and, subsequently, a lower rent and compulsory serf labor. However, the development of manorial farms at the turn of the 16th century brought about an increase of exploitation, which has been until then delayed by a low level of population density in the discussed terrains. The increase of compulsory villein service led to a series of Cossack uprisings in the second half of the 17 th century involving also the peasantry. ${ }^{410}$ These events can be interpreted in terms of an economic revolution of direct producers.

The characteristic feature of the economic development of the PolishLithuanian Commonwealth was an uneven population density, which blocked the rise of exploitation in the center and which shifted social struggle of the peasantry from central terrains onto peripheries.

409 Wyczański, Wieś, pp. 171-172.

410 Rusiński, Rozwój gospodarczy, p. 71. 


\subsection{The Hungarian Variant}

A single class of owners emerged in Hungary in the 12th and the 13th centuries as a result of the collapse of the system of the Ius Ducale. According to model III of an economic society, a low level of population density - in the 10th century, the country was inhabited by around 1 million people, forced owners to grant a number of concessions to direct producers. Weakness of the state caused by feudal fragmentation, which deprived the owners of the support of political authorities, constituted an additional circumstance bringing about an improvement of the economic situation of the peasantry.

The period of German colonization and settlement with German Law can be interpreted as a manifestation of concessions and production incentives on the part of feudal lords to the peasantry. The adoption and implementation of Western-European institutional solutions increased independence and privileges of the peasantry, and simultaneously stimulated their productivity. In the 12th and the 14th centuries, German colonization and settlement with German Law covered the terrains of the Pannonian Basin, Slovakia and Transylvania.

At this time the urban sphere emerged, which can be interpreted as a division of the economy into two sectors, according to the theses of model IV of feudal society. The development of towns in Hungary was confronted with the same obstacles, as in the rest of Central Europe: a low level of population density, which made it difficult to acquire sufficient manpower, competition from Western-European craft, and privileges of the nobility in the socio-economic life. The largest barrier was the shortage of workforce, which decreased the stream of migration of the peasantry to towns, by contributing to the improvement of the economic situation of this social class.

Let us stress once more that in a typical society of the region under study, towns emerged in the period of class peace between owners and direct producers of the rural economic system. The state of class peace, which resulted from the competition between owners for as much manpower as possible, caused migration to towns to be a less effective way of ensuring higher income. A limited inflow of workforce to towns made it difficult to acquire sufficient manpower. These problems were additionally deepened by a low level of population density in Hungary, in comparison to western societies, which influenced the development of both sectors of the economy.

The level of population density and its social consequences must have influenced the size of towns and the significance of burghers in the Hungarian society. In the peak period of the growth of the urban economy - that is, in the 15th century - there were around 30-35 towns in Hungary. By European 
standards, most of them were small. The largest, Buda, had a population of 8,000 , compared with 4,000-5,000 in the next largest towns: Bratislava, Sopron, Košice, and Cluj. In total, in the above-mentioned period, town population accounted for $3 \%$ of the Hungarian population. ${ }^{411}$

A characteristic trait of the development of towns in Hungary was the so-called oppidium - a center without a legal and political status of a town. Its inhabitants were subordinated to feudal jurisdiction: they had to pay tributes to the owner of the oppidium and perform a villein service. People living in those centers engaged partly in farming and partly in non-agricultural activities. An oppidium had institutions, such as schools, hospitals, or churches; thus, it functioned as a town. In that period, there were about 800 oppidia, each with about 500-1000 residents. ${ }^{412}$

Moreover, the international economic situation adversely affected the development of Hungarian towns:

The large-trends of international economic development were not favourable to urban development in Hungary. The impetus of industrialization was already lost by the late fifteenth and early sixteenth century. The agrarian boom of the sixteenth century then definitively prevented Hungarian domestic trade and crafts from breaking the mold of conservative guild, since the international movement of prices permitted the import of much more textile and metal goods than before in returns for the same quantity of cattle or wine. During the agrarian boom the returns for agricultural producers were not invested in industry; actually, they were not invested in agriculture either. ${ }^{413}$

Wars and the destruction they caused were additional factors, which hindered the development of towns. For example, after the loss of independence in 1526 and the division of the country into three parts, the largest towns of Hungary: Buda and Pest were reduced to the role of Turkish military garrisons.

In turn, the weakness of burghers contributed to strengthening the position of the nobility in a Hungarian society. The latter gained exclusive influence on political authorities. The period of reinforcement of state authority in the course of the development of a Hungarian society was followed by a trend typical for Central-European societies, namely an upward trend in the sphere of autonomy

411 Maria Bogucka, "The Towns of East-Central Europe from the Fourteenth to the Seventeenth Century," in: Central Europe in Transition. From the Fourteenth to the Seventeenth Century, eds. Peter Burke, Antoni Mączak and Henryk Samsonowicz (Cambridge: Cambridge University Press, 1985), p. 98.

412 Bogucka, "The Towns of East-Central Europe," p. 98.

413 Vera Zimányi, Economy and Society in Sixteenth and Seventeenth Century Hungary (1526-1650) (Budapeszt: Akademia Kiadó, 1987), p. 50. 
of a particular layer of the civil class (the nobility, or the owners of the means of production of the rural economic system) and a decrease of the sphere of state control. In Hungary, the above process was initiated as early as in the beginning of the 13th century. In 1222, the king of Hungary Andrew II announced the so-called Golden Bull. The document made magnates equal in rights with ordinary knighthood, which amounted for $5 \%$ of the Hungarian society. By virtue of that legal act, a lower layer of knighthood, the so-called serwienci, was exempted from taxes and was granted jurisdiction over the peasants. Moreover, the Golden Bull limited military service duty of serwienci to defensive wars. Since then, the Hungarian nobility could not be imprisoned without a court sentence. Furthermore, separate royal approval was required to confirm capital punishment of the representatives of this estate. The king was obliged to call estate assemblies once a year. The Golden Bull granted the nobility the right to resist the monarch if these provisions were contravened. Those provisions were repeated in the Golden Bull issued in 1351 by Louis I.

The social weakness of burghers, which stemmed from the economic underdevelopment of towns, was reflected in scarce participation of the representatives of that social group in estate assemblies of representatives. Since 1445, the deputies of towns, particularly of eight urban centers: Buda, Pest, Bratislava, Sopron, Turnawa, Bardejov, Prešov, and Košice, began to regularly participate in the Sejm debates. However, as early as in 1458, the role of town representatives was limited to hearing the resolutions and reporting on the debates to its electorate. In the 16th century, urban delegates were granted one collective vote. ${ }^{414}$

Another factor weakening the role of state authority were frequent changes of dynasties - during two hundred years, since 1301 when the Arpad dynasty ended, the Hungarians were ruled by kings from the Angevin, Luxemburgian, Hunyiady, and Jagiellon dynasties. Each time, a new monarch had to confirm privileges, which had been granted by his predecessors, before he could establish his position.

Subordination of the political authorities to landowners allowed the latter to use the instruments of state control to carry out their anti-municipal policy. For instance, in 1550, the Hungarian nobility obtained the right to buy up agricultural produce from their serfs. In 1617, the nobility became exempted from customs duties and taxes. A few years later, by using the instruments of state control, they subjected prices and wages to their own regulations. Another form

414 Russocki, “Monarchie stanowe," p. 77. 
of controlling the economic life was by granting the nobility of monopolies to manage inns, slaughterhouses, or mills, and exclusive rights to use of waters and forests, etc.

The subordination of the state to the nobility reduced the economic significance of the urban sector of production, which, in turn, constrained the development of towns. The Hungarian nobility could also use state regulations in order to increase profit to maximum in the rural sector of the economy.

The increase of the alienation of labor in the rural economic system can be identified with the rise and development of a manorial-serf economy. In a society with a shortage of manpower, the alienation of labor grows in a rural sector of the economy, provided that the class of owners is subordinated to political power and providing the competition of the second sector of the economy is limited. As we have seen, these phenomena occurred in the development of a Hungarian society. The nobility reduced the importance of towns and employed the instruments of state control to impose serfdom on the rural population and to increase the villein service.

In the 15th century, the economic structure of Hungary was characterized by heavy concentration of property. Around 1440, sixty largest magnates owned around $40 \%$ of all villages. However, own manors of feudal lords were small and the majority of their land was cultivated by leaseholders that paid the rent and provided payment in kind. On account of the small size of lords' farms, villein service was of little importance in the overall structure of peasant obligations in the 15th century, as it amounted only to 1-2 days annually. Relatively more important was rent in kind. Peasants were obliged to supply certain quantities of bread, cheese, butter, eggs, poultry, and all kinds of meat from 2 to 5 times a year. Apart from food, the rural population had to deliver tributes in grain and wine. In 1351, obligations imposed on rural farms increased because peasants had to provide additional tributes in grain: the so-called ninthe - the ninth part of the harvested crops (cf. tithe).

During that period, the most significant element in the structure of peasant obligations was rent paid in cash. Villages founded with German Law predominantly paid the rent. The average amount of rent was then equal to 1-1.5 florin per one male adult. In the second half of the 15th century, burdens imposed on the rural population increased as a result of the introduction of another tax, the so-called census. It was paid in 2-5 instalments and the rate depended on the number of owned livestock. The tax was almost as high as the remaining pecuniary duties. In the second half of the 15th century, landowners imposed on the peasantry a number of additional, extraordinary payments associated with the use of forests, meadows, waters, etc. Since the end of the 14th century, the 
growing obligations imposed on the peasantry caused their economic situation to deteriorate gradually. That process was accompanied by limiting the freedom of movement. At the end of the 15th century, by virtue of the state legislation issued in 1486 and reaffirmed in 1496, peasants could not leave the village without the lord's consent. The imposition of serfdom and increase of economic burdens in the second half of the 15th century, might be interpreted as an increase of the alienation of labor, which gave rise to a series of revolts of the producers of the rural sphere. ${ }^{415}$

One of the first revolts was a peasant uprising in the south of Transylvania, in the years 1437-1438. Within a short period, it gained support from pauperized burghers and the minor nobility. Very soon, the peasant revolt transformed into a military confrontation. At the beginning the insurgents achieved a victory in the battle at Des, which forced the ruling camp to sign a treaty in Kolozsmonostor. However, after burghers and the minor nobility turned over to the king's camp, the peasant insurgents were left without support. Despite the unfavorable power balance, the insurgents were once more victorious in the battle at Apati. The uprising ended with a defeat at Cluj-Napoca. As a consequence of the unsuccessful peasant revolt, the personal freedom of the peasantry was reduced, and part of privileges and rights of towns, which supported the Transylvanian uprising, was revoked.

The Dózsa's uprising was another peasant revolt which can be interpreted as an economic revolution of direct producers. ${ }^{416}$ As distinct from the Transylvanian peasant revolt, it had a mass character. It started in 1514 when peasant troops, which had mobilized for the expedition against the Turks, refused to disperse and begun an open revolt. The rebels demanded abolition of serfdom and class divisions, distribution of land and liquidation of nobility jurisdiction. Urban dwellers joined the rebellion, which quickly transformed into a military confrontation. The revolt ended with a defeat at Timișoara in 1514. After suppressing the rebellion, the authorities resorted to mass terror, murdered around 50,000

415 Zsigmond Pal Pach, "The Development of Feudal Rent in Hungary in the Fifteenth Century," The Economic History Review, 2nd ser., Vol. 19, No. 1 (1966), pp. 1-14.

416 Cf. Juliusz Demel, Historia Rumunii (Wrocław: Ossolineum, 1986), pp. 145-147; Waclaw Felczak, Historia Węgier (Wrocław: Ossolineum, 1983), pp. 111-112; David Prodan, “The Origins of Serfdom in Transylvania," Slavic Review, Vol. 49, No. 1 (1990), pp. 1-18; Jerzy Reychman, Dzieje Węgier (Łódź: PWN, 1963), p. 26; J. Szekely, "Ideologia wojny chłopskiej na Węgrzech w 1514 r.," Kwartalnik Historyczny, Vol. 67, No. 3 (1960), pp. 634-649. 
participants and burned the peasant leader Dózsa on a wooden throne. The crush of the Dózsa uprising was followed by a period, which can be interpreted in terms of economic declassation and political enslavement of peasants-serfs. A codified body of legislation termed Tripartitum, issued after the crush of the revolution, was to regulate the scope of the nobility's power over the peasantry. According to this legal act, the peasants were not allowed to freely leave their village and were forbidden to carry arms. They also had to pay for the made damages. The peasants were denied opportunities of social advancement because they could not hold high-ranking church offices. Tripartitum introduced the obligation to pay additional tax in the amount of one florin and to perform one day of villein service. ${ }^{417}$ In the course of development of manorial-serf economy, the compulsory serf labor became the principal duty of the peasantry. During the 16th century, it increased from 1 day to 3-4 days a week. In the same century the acreage of manorial land grew from $10 \%$ to $40 \%$. Another form of economic exploitation were monopolies established by the Hungarian nobility. In the 16th century, the Hungarian nobility introduced an exclusive right to own inns, slaughterhouses, to purchase mandatory quota of wine and grain from the peasantry, the right to fish and the right to collect acorns in the woods to feed swine. In that period they also introduced the propination law and the obligation to grind grain in lord's mills. ${ }^{418}$

In Hungary, a manorial-serf economy originated in the period of the collapse of the medieval trade exchange, in which luxury goods were staple commodities, and in the period of development of the modern trade exchange. The principal objects of the modern exchange were goods of mass consumption. ${ }^{419}$ The Hungarian economy integrated with the new structure of international trade. The demand for agricultural products was one of the factors, which accelerated the transformation of the agricultural system of that state. ${ }^{420}$ However, unlike in Poland, grain did not play an important role in Hungarian exports. ${ }^{421}$ This

417 Bela K. Király, “Neo-Serfdom in Hungary,” Slavic Review, No. 2 (1975), p. 269. Janos Bak, “The Late Medieval Period, 1382-1525," in: History of Hungary, eds. Peter F. Sugar, Péter Hanák, and Tibor Frank (Indiana: Indiana University Press, 1990), pp. 78-80.

418 Gyorgy Komoroczy, "Przegląd badań z zakresu węgierskiej historii gospodarczej opublikowanych w latach 1938-58," Roczniki Dziejów Społecznych i Gospodarczych, Vol. 22 (1960), p. 167; Laslo Mákkai, Agrarian Landscapes of Historical Hungary in Feudal Times (Budapeszt: Akademia Kiadó, 1980), p. 11.

419 Pach, The Role of East-Central Europe, pp. 218-219.

420 Zimányi, Economy and Society, p. 30.

421 Mákkai, Agrarian Landscapes, p. 13; Pach, The Role of East-Central Europe, p. 251. 
state of affairs was a consequence of absence of convenient communication routes (river passages and seaways), which precluded sending large amounts of grain abroad. ${ }^{422}$ Wine and cattle were Hungarian export commodities. Since the second half of the 14th century, the country was a big exporter of cattle. It was sold to Bohemia, Austria, southern Germany, and northern Italy. In the 16th and the 17 th centuries, there were on average between 100,000 to 200,000 heads of cattle exported annually, which at that time accounted for $2.5-5 \%$ of the overall production of cattle. The second export commodity was wine. In 1550-1650, ca. $100,000 \mathrm{hl}$ of wine (about 10-15\% of domestic production) was sent abroad. Out of the total value of Hungarian export in the 16th and the 17th centuries, oxen accounted for ca. $26 \%$, wine for $8.1 \%$, grain for $15.2 \%$, wool for $11 \%$, and minerals for $39 \%$ of the sale value. ${ }^{423}$ Hungary imported highly processed industrial goods, textiles, and luxury goods.

The event that disrupted the development of Hungary was the Turkish invasion of 1526, which brought about a Turkish occupation of the southern part of the country, which lasted for over 100 years. Moreover, the western part of Hungary has been under the rule of the Habsburgs since 1541. One third of the former kingdom of Hungary, namely Transylvania, retained independence in the 16th century. Following the defeat of Turkey at Vienna in 1687-1699, all former lands of St. Stephan's crown found themselves under the rule of the Habsburgs. The Turkish occupation was a period of war destruction, a substantial drop of the level of population density, and a collapse of the urban sector of the economy. In that sense, the Turkish occupation was another factor in the Hungarian variant of the cascade of European differentiation, which contributed to the developmental distinctiveness of that society.

In summary, the Hungarian variant of the cascade of European differentiation can be demonstrated graphically in the following way (see page 307 ).

422 Pach, The Role of East-Central Europe, p. 251.

423 Istvan N. Kiss, "Agricultural and Livestock Production: Wine and Oxen. The Case of Hungary," in: Central Europe in Transition. From the Fourteenth to the Seventeenth Century, eds. Peter Burke, Antoni Mączak and Henryk Samsonowicz (Cambridge: Cambridge University Press, 1985), pp. 88-96. 


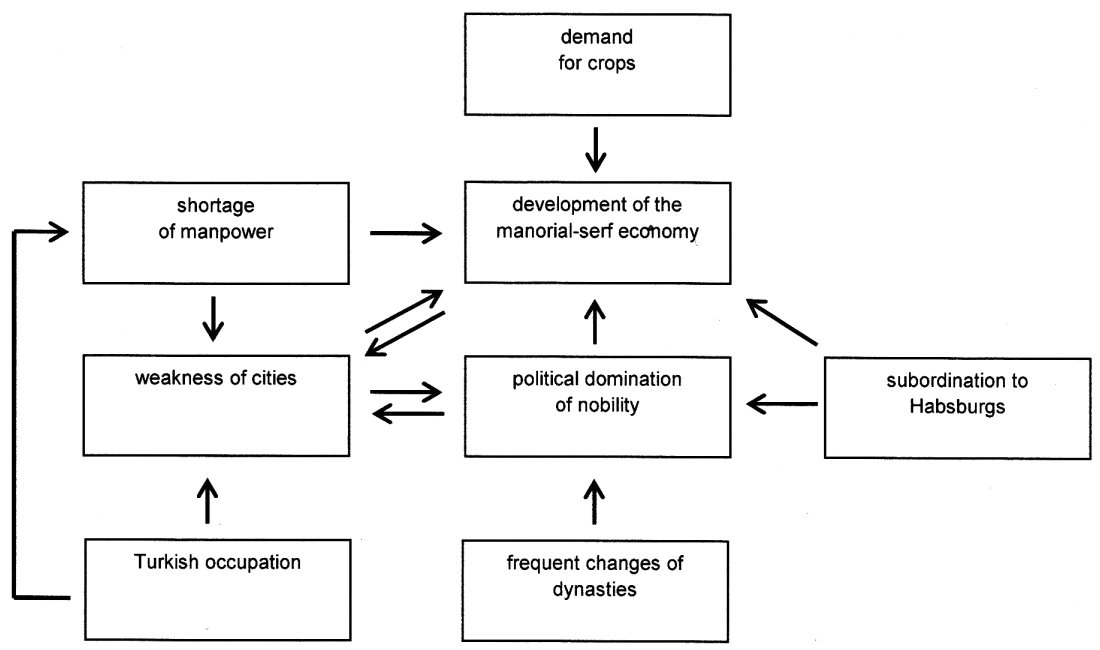

Fig. 25: The Hungarian variant of the cascade of developmental differentiation.

\subsection{The Bohemian Variant}

The system of the Ius Ducale prevailed in the Bohemian society between the 10th and the 12th centuries, similarly to the situation in other countries of the region. The system has gradually disappeared in the 12th and the 13th centuries, and the double social class that controlled the means of production and coercion was replaced by knighthood, which was a counterpart of the single class of owners from model III of an economic society. Bohemia was characterized by a low level of population density, with less than 1 million people living in the country. This demographic situation, according to the tendencies of model III of an economic society, enforced concession. Their counterparts were introduction of German Law between the 12th and the 14th centuries, which brought about substantially higher privileges to the peasantry than the previous socio-economic system.

A split of the economy into two sectors and a development of the urban sphere of production took place in the above-described phase of social evolution. Towns, which emerged in the phase of granting concessions by the class of owners, were confronted with the same obstacles for further development, as towns in other urban centers of the region. Problems with acquisition of manpower were the major barrier of development. These problems were a consequence of two factors: the state of class peace in the rural economic sector, on the one hand, and the shortage of workforce, on the other. Noteworthy, the development of the Bohemian urban 
sphere was confronted with relatively smaller obstacles, in comparison to the situation in Poland and in Hungary, due to the higher level of population density and intense German colonization.

The percentage of town dwellers was higher than in the other CentralEuropean countries, as it accounted for around $20 \%$ of the population. The largest town in Central Europe was Prague, with 30,000-40,000 inhabitants. In other Bohemian towns, the population ranged from 5,000 to 10,000 each. ${ }^{424}$ The strength of Bohemian burghers was reflected in the newly forming estate system. Delegates of royal towns (around 30) participated in Sejms and assemblies of the local nobility as early as in the 15th century. The strong position of towns influenced the situation in the rural sector of the economy by reducing the scope of feudal control over the peasantry:

[T] he socio-political significance of Czech towns contributed to the state of affairs whereby it was more difficult to free vassals because the towns strengthened by their gains during the Hussite revolution, felt the need for workers and encouraged them both to settle in the towns and to learn a craft, and even to complete university studies. The diet passed decrees insisting that the towns should returns vassals to their masters, when they had left without permission; but in fact it was impossible to put these decrees into effect and to prevent the natural flow of the population from the villages to the towns. ${ }^{425}$

At the turn of the 15th and the 16th centuries, the nobility attempted to execute its growing political superiority by limiting political privileges of burghers by devising a new codification of law, the so-called Vladislav's Land Statutes. Burghers responded with establishing an urban association of 32 towns. Organized protests of burghers forced the nobility to grant Bohemian burghers with full representation in estate assemblies in the so-called Saint Wenceslaus Agreement of 1517.

Since the direct limitation of burghers' rights by the nobility was impossible, though tendencies of that kind could be observed as early as the turn of the 15th and the 16th centuries. Therefore, the nobility sought other ways to undermine the social position of burghers. For instance, landowners founded private towns and villages. The inhabitants of those centers did not enjoy full autonomy despite fulfilling all economic functions of a town. Between 1434 and 1620, almost 40 towns and 150 villages of the nobility came into existence. ${ }^{426}$ This led to an autarky of

424 Bogucka, “The Towns of East-Central Europe”, pp. 98, 100.

425 Josef Macek, “The Emergence of Serfdom in the Czech Lands," East-Central Europe, Vol. 9, Nos. 1-2 (1982), p. 21.

426 Alois Mika, "Rozwój gospodarki dworskiej na ziemiach czeskich od XIV do XVII w.," Roczniki Dziejów Społecznych i Gospodarczych, Vol. 22 (1960), p. 15. 
the rural economy. The nobility closed the borders of its manors to craft products manufactured in royal towns. In exchange, it forced its serfs to purchase products manufactured in private towns. Trade exchange concentrated in private towns and the town owners obtained the greater part of profits from it, in the form of customs duties, tolls, etc. The rural market was closed to town products with administrative methods, which diminished the prospects for development of the urban sphere of production. As a result, burghers lost their strong social position.

The relative balance between the influences of the principal social forces namely, burghers, the nobility, and the political authority - contributed to the situation of the peasantry. In 1487 the Bohemian Parliament issued a bill, which reduced migration of the peasantry, however it was not put into practice. During the 15th century and the greater part of the 16th century, the rural population maintained personal freedom, and the burden of the villein service did not exceed 12 days a year.

The factor responsible for undermining the balance between the nobility and burghers, and for accelerating the process of differentiation of the Bohemian developmental path, was the imposition of the Habsburg domination over the Bohemian society. In the 15th century, after the death of George of Podébrady, Louis II of Hungary became the king of Bohemia and Hungary. After his death in the battle at Mohács in 1526, the rule over Bohemia was transferred to Ferdinand I, and the lands belonging to St. Václav's crown were incorporated into the Habsburg Empire. The Habsburg rule strengthened the prerogatives of the central authority, and brought about an increase of fiscal burdens and a limitation of estate privileges, both for the nobility and burghers. In 1546-1547, an anti-Habsburg uprising of the Bohemian estates broke out during the war between Ferdinand I and the Schmalkaldic League. The pretext for the uprising was the mass levy of the nobility summoned by the emperor without the consent of the Sejm, which was supposed to be used in the ongoing war in Germany. Both burghers and the nobility participated in the rebellion. The insurgents refused to participate in the war in Germany and established their own government with armed forces. However, after the victory over the Schmalkaldic League, Ferdinand I suppressed the revolt of the Bohemian estates. In 1547, the sovereign struck a compromise with the nobility while repressing burghers. As a result, he broke the solidarity of the Bohemian opposition. After the unsuccessful uprising, the Habsburg authority confiscated military equipment, which belonged to towns and forbade burghers to carry arms. The repressions of the central authority undermined the economic privileges of burghers: towns were deprived of the greater part of the landed estates and burghers were burdened with substantial taxes. Moreover, the Habsburgs restricted the autonomy of 
Bohemian towns by revoking a number of urban and guild privileges. Town deputies were deprived of the right to speak during estate assemblies. From that moment, the matters of public order in towns were to be controlled by royal police officers and village officers who additionally supervised guild organizations. The emperor Ferdinand I abolished the judicial autonomy of burghers with an establishment of the national court of appeal in Prague in $1548 .{ }^{427}$

A consequence of undermining the social balance between the two estates was about a deterioration of the situation of the peasantry in the second half of the 16th century. During that period, the transformation of the manorial farms was initiated. Also, in the second half of the 16th century, a gradual concentration of land began: the number of manorial farms with acreage between 5 and $10 \mathrm{tan}$ was constantly growing. ${ }^{428}$ In 16th-century Bohemia, the production of grain for export was not of great significance. ${ }^{429}$ Production for the domestic market was more important. The principal production of the nobility manors included fishing, beer brewing, and sheep breeding, among others. Landowners also established a number of craft works: mills, brickyards, sawmills, etc. Privileges received from political authorities allowed the nobility to secure, for example, the monopoly for grinding grain or selling beer to its subjects. Simultaneously, the situation of the peasantry systematically deteriorated. The owners burdened the rural population with additional fees for the use of meadows and forests, fishing and the export of goods for sale to towns. In the first half of the 16th century, villein service was still unsubstantial: it amounted for the maximum of 12 days a year, and its average scope was 6 days. ${ }^{430}$ However, in the second half of the 16th century it grew to several dozens of days annually. Apart from compulsory villein service, the nobility burdened the rural population with an obligation to perform all kinds of occasional work for the manors. In 1575, the freedom to seek hired labor by peasants who owned little land and landless peasants was limited to four weeks annually. ${ }^{431}$

427 Václav Husa, Historia Czechosłowacji (Praga: Artia, 1967), pp. 96-98; Harrison Thomson, Czechoslovakia in European History (Princeton: Prinveton University Press, 1944), pp. 61-62.

428 Mika, "Rozwój gospodarki dworskiej”, pp. 16-17.

429 Vera Sadova, "Eksport czeskiego zboża do Niemiec a rozwój produkcji towarowej w Czechach w okresie przedbiałogórskim," Roczniki Dziejów Społecznych i Gospodarczych, Vol. 22 (1960), p. 37.

430 Macek, “The Emergence of Serfdom,” p. 19; Anton Špiesz, "Czechoslovakia's Place in the Agrarian Development of Middle and East Europe of Modern Times," Studia Historica Slovaca, Vol. 6 (1969), p. 43.

431 Roman Heckand Marian Orzechowski, Historia Czechosłowacji (Wrocław: Ossolineum, 1969), p. 147. 
The weakened position of burghers and the compromise reached by the Habsburgs and the Bohemian nobility led to the above course of social events. The gradual deterioration of the economic situation of the peasantry, which can be interpreted as an increase of the alienation of labor in terms of a model of an economic society, brought about first local signs of peasant resistance at the end of the 16th century. In 1575, there were outbursts in the vicinity of Přibram and Rožmitál. A year later, peasants from Mladá Boleslav revolted. At the turn of the 16th century a number of local but long-lasting conflicts broke out in the manors: Skaly at Broumov (1592-1618), Hukvaldy (1588-1617), and Jablonné (1609-1610).

The next factor in the Bohemian variant of the cascade of European differentiation, exerting the greatest influence on the developmental path of the country, were the consequences of the failed anti-Habsburg uprising and the Thirty Years' War (1618-1648). In 1618, another anti-Habsburg uprising broke out, in which united forces of burghers and the nobility took part once again. After the defeat at White Mountain (Bílé hoře, 1620), in which around 21,000 Bohemian nobles were killed, the Habsburgs used mass repression against the rebelling states, including the confiscation of about three fourths of nobility estates. The manors were distributed among the population that was loyal to the political authority, mainly Germans, Italians, Frenchmen, and Walloons in service to the Habsburgs. ${ }^{432}$ The change in the ethnic make-up of the nobility, which was not bonded with the peasantry (direct producers) by shared national awareness, brought about a growing exploitation of the rural sector of production. William E. Wright describes the economic consequences of the battle of White Mountain as follows:

The old Bohemian aristocracy, which had accepted the restraints of custom and law and had exhibited a certain degree of paternalism in their relations with the peasants were decimated by exile and confiscation of property after the imperial victories. A new aristocracy replaced the old, took possession of much of the landed property of Bohemia and therewith took control also of a large segment of the Bohemian peasant population. These new men were mostly foreigners and conquerors being rewarded for their services in defeating the "heretics" of Bohemia. They felt in no wise bound by the ancient and paternalist restraints of the ameliorating customs and laws which tempered the old lords' actions towards the peasants. ${ }^{433}$

Apart from the change in the ethnic composition of the class of owners, both anti-Habsburg uprisings and military operations resulted with vast war damage.

432 Heck, Orzechowski, Historia Czechosłowacji, p. 161.

433 William E. Wright, "Neo-Serfdom in Bohemia," Slavic Review, No. 2 (1975), p. 246. 
In Bohemia alone, 80 towns and 813 villages were devastated, and in Moravia 22 towns and 333 villages were destroyed. ${ }^{434}$ Furthermore, the people of Bohemia suffered catastrophic losses: the population of Bohemia dropped from 1.7 million (1618) to 0.9 million (1648), which represented a drop by $40 \%$. ${ }^{435}$ War damage undermined the development of the urban sphere of economy. As a result, the alternative sector of the economy disappeared. Its presence used to somehow temper the growth of exploitation of the rural sector of production. In contrast, confiscation of estates belonging to the Bohemian nobility removed the obstacles to a firm alliance between the political authority and grand ownership. The aristocracy withdrew from any attempts to control the action of the royal authority in the political sphere, in return for guarantees and support of the political authority in pursuing an almost unlimited exploitation of the peasantry. The Thirty Years' War, affecting the change in social relations among the principal classes in Bohemian society, was a turning point in the history of Bohemia. War damage led to a drastic deficiency of manpower, which, in turn, resulted with the following situation:

[L]ack of workforce was counterbalanced by imposing an increased burden of villein service on serfs. Before the defeat at the White Mountain, the serfs were obliged to serve for only a few days a year, whereas after the Thirty Years' War the villein service rose incomparably. Landowners introduced almost a daylong villein work for the greater part of the year. Thus, the peasants cultivated their own land at night, on Sundays and during holidays. Beside the mandatory villein service, they had to cope with increasingly growing obligations of rent and tributes. ${ }^{436}$

Another consequence of the decrease in rural population was the increase in uncultivated land, which, in turn, facilitated the concentration of land by the nobility and founding of manorial-based farms. According to model III of an economic society, the shortage of manpower forced owners to grant economy concessions. However, this course of events is possible only in a purely economic society deprived of administrators of centralized means of coercion, among other things. Its approximation may be a society with a class of owners divided into two social sub-categories: owners of the old economic sector (nobility) and owners of the new economic sector (burghers). Social balance between burghers and the nobility results with a state of affairs in which political authorities are not under the influence of any of the above-mentioned social groups. Under the conditions of a social balance defined as above, none of the social classes subjects the authorities

434 Heck, Orzechowski, Historia Czechosłowacji, p. 162.

435 Anton Klima, "Agrarian Class and Economic Development in Pre-Industrial Bohemia," Past and Present, Vol. 85 (1979), p. 52.

436 Husa, Historia Czechosłowacji, p. 115, cf. Klima, “Agrarian Class,” pp. 50-51. 
to its interests; therefore, it is possible to reasonably abstract from the influence it exerts on the economic relations inside each of the spheres of production. In a society with a scarcity of manpower, the mechanisms described in model III of an economic society substantially contribute to mitigation of exploitation. However, the developmental mechanisms changed in a society in which the dominance of the nobility over burghers replaces social balance. Then, the nobility subordinates political authorities to its interests. Owners may exercise the instruments of state coercion with regard to direct producers. This means that, under the conditions of deficiency of manpower, economic concessions have no effect, because owners also administer the means of coercion (not indirectly, but via the authorities subordinated to them) and may push toward tightening the exploitation. Then, social enslavement of serfs prevents escapes and migration - the situation of shortage of workforce is the principal weapon of direct producers.

Such was the picture of the Bohemian society in the middle of the 17th century. War damage considerably devastated the urban economy. In contrast, landowners, whose attitude to nationality was different from the remaining part of the Bohemian society, could easily ask state authorities for support. According to Klima, the factor facilitating an introduction of serfdom was the situation that:

this fundamental economic relationship [serfdom] was reinforced and strengthened by the fact that, in Bohemia, as in other countries, a peasant-serf was also subject to his lord in political and legal matters. This in turn allowed the lord to intensify exploitation depending on the circumstances. ${ }^{437}$

After 1620, compulsory serf labor increased to 3 days per week. That considerable growth of exploitation provoked an outbreak of an anti-Habsburg uprising of peasants directed, both, against the authority and ownership. The uprising broke in 1626-1628 in Bohemia, Moravia, and Silesia. The authorities suppressed the uprising. After the defeat of the anti-Habsburg uprising, the alliance between political authorities and ownership subjected the Bohemian rural class to economic declassation of political enslavement. This is how the "Land Arrangements" introduced in 1627 in Bohemia, in 1628 in Moravia, and in 1652 in Silesia, which forbade serfs to leave their village without the consent of the lord, can be interpreted. Moreover, serfs could not enter into marriages without the approval of a village owner. Serfdom was also to cover peasant children. They were forbidden to train in craft and change the profession inherited from their parents without the consent of the noble lords. A principle was enforced under which children born of female serfs automatically became serfs of

437 Klima, "Agrarian Class," p. 51. 
the same owner. Limitation of the sphere of autonomy of direct producers was accompanied by growth in economic obligations to 4 days a week and, moreover, peasants were obliged to pay taxes to the state and church. The burdens imposed on peasants in the 17 th century accounted in total for $60 \%$ of gross income. ${ }^{438}$ The rise of exploitation was also accompanied by political pressure, which was manifested with very harsh penalties for insubordination, among other things:

The lord had the right to punish serfs with death for desertion, heresy and even poaching. Lesser offenses or noncompliance with obligations in relation to a landowner were punished with flogging, tortures, burning out shameful marks, pillory or other ways of abuse. The extent of punishment depended solely upon the feudal lord or his bursar. ${ }^{439}$

As a result, a manorial-serf economy came to existence in the Bohemian society in the second half of the 17th century, which decided on the developmental differentiation of this society. Let us now present the factors, which determined the distinctiveness of the Bohemian variant of the cascade of European differentiation in a graphic form:

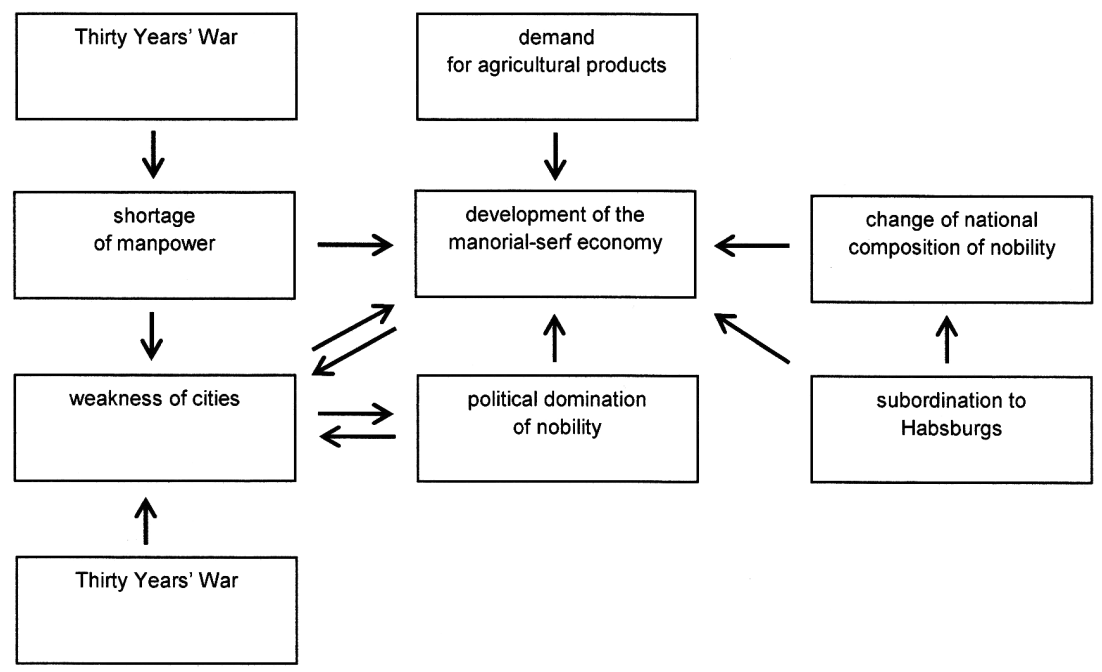

Fig. 26: The Bohemian variant of the cascade of European differentiation.

438 Heck, Orzechowski, Historia Czechosłowacji, p. 166.

439 Husa, Historia Czechosłowacji, pp. 116-117. 
A developmental peculiarity of the Bohemian manorial-serf system was the presence of a strong, absolutist state. In the first period of existence of a manorialserf economy in Bohemia, namely in the second half of the 17th and the first half of the 18th centuries, the state ensured implementation of the class interests of the owners. However, a state of class compromise prevailed, instead of a relationship founded on subordination of the authorities to ownership. The owners resigned from controlling political action of the political authorities in exchange for an assurance of unlimited exploitation of direct producers. However, this compromise did not last forever. It lasted as long as it was beneficial for both parties. As soon as the stronger party reached a conclusion that the shape of the compromise posed a threat to the implementation of its class interest, it attempts to revise the conditions of the compromise. In the Habsburg state, the conflict of interests between the authorities and the ownership was founded on the fact that the peasantry played a double social role of direct producers and taxpayers. Thus, the limitation of exploitation carried out by ownership was in the interest of the authorities. The period of absolutism in the second half of the 18th century and the intervention of the state into the relations between a lord and a peasant influenced by the peasant uprisings may be interpreted in the above way. The periodic peasant revolutions directed against the economic rule also threatened the interest of the authorities and forced the latter to intervene into the relations between a peasant and a lord. The first in a long series of peasant uprisings were local rebellions near Litomyšl in 1656-65, Limeryce in 1668, and in the region of Turnawa in 1673. All of these rebellions concluded with a defeat of the peasantry and repressions against the participants.

The growing intensification of poverty, caused, among others, by a severe winter of 1679-1680, brought about a widespread series of peasant incidents, which may be interpreted in terms of a revolution of the II type. In 1680, the incidents covered western and northern Bohemia, Moravia, and Silesia. The authorities used regular military forces to suppress the uprising, and it took a number of bloody battles between the military forces and the peasant troops. After the suppression of the uprising, political authorities introduced repressions followed by concessions in the form of a regulation of the economic relations between the nobility and the peasantry. The Emperor's Patent issued in $1680 \mathrm{lim}$ ited the scope of serfdom to 3 days a week.

Since then, the social development has unfolded according to the following model: increase of the alienation of labor - revolution of direct producers intervention of the political authorities pacifying the uprisings - repressions against the participants and short-lasting mitigation of exploitation - increase of the alienation of labor leading to another revolution. The intervention of royal 
authorities in 1680 brought about little effect, which is why another peasant rebellion broke out in Bohemia in 1738. In consequence, the authorities introduced repressions and limited the scope of serfdom. The state intervention on the part of direct producers was short-lasting because the economic living conditions of the peasantry deteriorated once more after a period of time. This situation once more brought about peasant rebellions, which in 1767 covered 137 municipalities in Cieszyn Silesia. The authorities responded once more with repressions and an attempt to intervene into the economic relations in the rural region. The scope of exploitation was mitigated; however, it re-grew after a while. In 1775, another peasant uprising broke out, the largest so far. Its participants formed a "Rural Government," which included peasants of German and Czech origin. The uprisings had a very violent character - peasants burned lord's manors, destroyed the books, which consolidated the obligations of the rural population, and attempted to conquer Prague. Regular military forces, which amounted to around 40.000 , were used to suppress the uprising. This time, the intervention of political authorities, following the suppression of the revolution, brought about effects, which were more sustainable and more beneficial to the peasantry. In the Emperor's Patent issued for Bohemia in 1775, the scope of serfdom was depended on the size of land owned by peasants. The document also supported substitution of serfdom with rent.

A hypothesis that a classic manorial-serf economy has not developed in Bohemia $^{440}$ or that Bohemian economy represented an intermediate type of economy is founded on the presence of a state, which limited the growth of exploitation. ${ }^{441}$ Even if the above statement was true - I do not wish to get into a detailed analysis of issues secondary for this book - than it still does not contradict the theses put forward here, according to which the alienation of labor increased in Central Europe under the influence of the factors of European differentiation. It is secondary matter whether this increase occurred within the institutional frames of a noble's demesne based on villein service, or within the frame of another social form. The argument supporting a deterioration of the situation of the peasantry may be a series of peasant revolts periodically repeated in the second half of the 17 th century and in the 18 th century.

440 Cf. Mákkai, Agrarian Landscapes, p. 230; Špiesz, “Czechoslovakia’s Place,” p. 58.

441 The above statement applies to Hungary to a smaller extent because a manorial-serf economy developed in this country earlier and it enjoyed a larger autonomy from the Habsburg monarchy. 


\section{Summary}

Let us now briefly recapitulate the considerations presented in the fourth part of this book The above analysis has a mixed, theoretical-empirical character. The chapter "Models of the source of a cascade" analyzes a model of society with a shortage of manpower. The factor of shortage of workforce brought about an improvement to the situation of direct producers and mitigated the course of the social conflict. However, this model can explain only a particular fragment of the history of Central-European societies, namely colonization with German Law in the 13th-14th centuries, when the situation of the peasantry improved substantially. However, the further historical development of Central-European societies stands in contradiction with the tendencies assumed by model III of an economic society. This state of affairs is a result of a combined influence exerted by a cascade of secondary factors, which dominated the impact of developmental mechanisms assumed by the model. The present chapter subjected the impact of these secondary factors to an empirical analysis.

Between the 12th and the 14th centuries, a shortage of workforce contributed to an improvement of the situation of the peasantry and influenced the conditions of development of the urban sphere of economy in Central Europe. A decrease of the alienation of labor limited the scope of migration of peasants to towns. Consequently, the urban sphere became underdeveloped and the social balance between burghers and the nobility was undermined. This, in turn, allowed the latter to subordinate the authorities to its interests. The political dominance of the nobility allowed for a further confinement of the development of towns, an exacerbation of serfdom, and the introduction of a serfdom-based farm. The economic exploitation continued to intensify within the institutional frames of a manorial-serf economy. Providing the nobility was deprived of the support of the state, it behaved according to regularities assumed by the model. However, as soon as it gained exclusive influence on the state authorities, it effectively reduced the privileges of burghers and stopped granting concessions to the peasantry. The above processes were accompanied by an increased demand for grain in Western Europe.

The above factors exerted influenced on each of the central-European societies under study. However, particular factors determined a developmental path for each of them. In the case of Poland, it was the factor of uneven population density, which shifted the class struggle from the center toward peripheries; in the case of Bohemia, it was the domination of the Habsburgs and the outcome of the Thirty Years' War; in the case of Hungary, it was a Turkish occupation, etc. The combined impact of the core factors and the accidental factors brought about 
a progressing differentiation of the developmental paths of each of the societies investigated, located within the Central-European course of development.

The development of the manorial-serf system brought about a collapse of towns and a delay in the development of capitalistic ownership relations. An increased alienation of labor in the rural sector of the economy led to the weakness of towns. The size of the urban sphere shrunk to the purchasing capabilities of the peasantry. However, a delay in a formation of capitalistic rules of ownership was, among others, a consequence of a compromise between the authorities and grand ownership (Bohemia and Hungary under the Habsburg monarchy) or a subordination of the authorities to ownership (Poland before the Partitions). Owners revoked to the support of the state in their conflict with direct producers, which, in turn, postponed a revision of rules of ownership. It was not until the revolutionary wave in the period of the Spring of Nations, that the core of ruling of both social classes was shaken and that considerable changes were introduced into the structure of ownership. In the greater part of Central-European countries villein service and the personal serfdom of the peasantry was abolished in 1848. Serfdom was finally liquidated on the Polish lands belonging to Russia in 1864. As a result, capitalistic rules of ownership begun to form in the rural sector of the economy, which, in turn, brought about migration of the peasantry to towns.

Nonetheless, Central-European capitalisms manifested a number of structural differences, in comparison to the Western-European capitalism. To put it in general terms, this distinctiveness was associated with the fact that in the course of the development of Central-European societies, an effort to reach a state of social balance, termed "civil society," was not present. In the conceptual apparatus of $\mathrm{n}-\mathrm{Mhm}$, this social state may be characterized by three parameters. The first parameter is a class peace prevailing between owners and direct producers. In a capitalistic economy, it is a result of ongoing technical advancement, which secures prosperity for all social classes. The second parameter is a class peace between rulers and the civil class. This state is brought about by victorious civil revolutions - English, French, the period of the Spring of Nations, etc., which permanently reduced the scope of state control to a strip of administration. And finally, the third parameter of the social state under study is a social balance between authorities and ownership. This social balance is reinforced not only by an alliance of authorities and direct producers but also by an alliance between owners and a civil class. The authorities intervene into economic life on behalf of direct producers, while the owners support the civil masses in limiting the authorities. A social stalemate between the principal social forces is required for the institutions of civil society to be created. The state of social balance between 
the major social forces brings about effectiveness of a parliamentary democracy, of the institutions of free elections, of the right to form labor unions, etc. Under the above-described social conditions, the principal factors of social development shift from a material to an institutional level.

However, the social development of Central Europe was deprived of the natural aspiration of the class societies for the state of balance. The relationship between authorities and citizens cannot be characterized in the categories of the state of social peace. The above was manifested by an absence of advanced institutions of civil society in Russia and Austro-Hungary - predominantly, parliamentary democracy, and free elections.

An underdevelopment of industry was another characteristic feature of the social development of this part of Europe. In the 19th century, and in the first part of the 20th century, the majority of manpower was employed in the rural areas. Following from this, a delayed industrialization of Central Europe covered a substantially smaller area of economic life. Because of technical backwardness, the societies could not take advantage of the prosperity brought about by technical advancement. For this reason, relations between owners and direct producers cannot be characterized in terms of the state of class peace. Additionally, the authorities and the ownership did not form a balance of influences, characteristic for advanced capitalism. The scope of interference of state authorities into the social life of Central-European countries was larger, in comparison to any Western-European country. State-control of the economic life was so extensive, that in fact there was no free-market economy in Central Europe in the second half of the 19th century.

The First World War and the national social revolutions of 1917-1919 brought about a collapse of the empires of the houses of Hohenzollerns, Romanovs, and Habsburgs, which, in turn, created a foundation for a development of civil society. A parliamentary democracy and the intuition of free elections were introduced into all national societies. The relations between principal social forces - ownership and authorities - determined the fate of institutions of civil society. In the countries where the tradition of despotism was strongest (Russia) and private property had a weak position against the state apparatus, political authorities, which stemmed from a revolution due to a civil loop, gained control over the economy and developed a totalitarian system, followed by a socialist system. In contrast, the countries with an industrial-agricultural economy (Czechoslovakia), where private property held the strongest position, maintained a stable civil society throughout the interwar period. In the case of countries with an agricultural or agricultural-industrial economy (Bulgaria, Estonia, Yugoslavia, Lithuania, Latvia, Poland, Romania, Hungary), situated 
between the two extreme examples presented above, an authoritarian political system emerged at some point in history. ${ }^{442}$ These political systems were introduced in the course of military coups or coups supported by a neutral army, as a response to a crisis in the functioning of a parliamentary democracy. Politicians connected with power elites took power in the course of authoritarian coups d'etat; therefore, it was not necessary to create mass movements of political support. The change in power brought about an autocratization of the political system. Depending on the country, the following occurred: a limitation or abolishment of the system of representative democracy, blending of differences between legislature, judiciary and executive, and considerable strengthening of the latter. In authoritarian systems, in contrast to totalitarian systems, independent institutions of civil society existed, however they were restrained to an economic and a social sphere. Additionally, authoritarian power did not intervene into the competencies of religious institutions and did not attempt to take full control over the means of production. ${ }^{443}$ Although the scope of economic state control in an authoritarian system was smaller than the scope of economic control in a totalitarian system, it was considerably larger than the scope of control in a typical system of democratic capitalism. The intermediate position of the authoritative system could explain the reasons why the triple-lordship system was implemented in Central Europe with such ease between 1944 and 1949.

Following from this, from the perspective of the longue durée, the sources of problems in the transition to democratic capitalism after 1989 were not merely direct consequences of socialism. Indeed, they have lain much deeper. ${ }^{44}$ The

442 On the association between level of economy and authoritarian systems, see: Jerzy Tomaszewski, "The Economy of Central and South-Eastern European Countries during the Inter-War Years," in: Dictatorships in East-Central Europe 1918-1939. Anthologies, ed. Janusz Żarnowski (Wrocław: Ossolineum, 1983), pp. 57-83.

443 Andrzej Ajnenkiel, “The Evolution of the Forms of Government in Central Europe. 1918-1939," in: Dictatorships in East-Central Europe 1918-1939, ed. Janusz Żarnowski (Wrocław: Ossolineum, 1983), pp. 27-57; Władysław Kulesza, Koncepcje ideowopolityczne obozu rządzacego w Polsce w latach 1926-1935 (Wrocław: Ossolineum, 1985); Franciszek Ryszka, "European Fascism. Divergences and Similarities. Prospects of Comparative Research," in: Dictatorships in East-Central Europe 1918-1939, ed. Janusz Żarnowski (Wrocław: Ossolineum, 1983), pp. 223-247; Janusz Żarnowski, "Authoritarian Systems in Central and South-Eastern Europe (1918-1939). Analogies and Differences," in: Dictatorships in East-Central Europe 1918-1939, ed. Janusz Żarnowski (Wrocław: Ossolineum, 1983), pp. 9-27.

444 On the impact of real socialism, see: Krzysztof Brzechczyn, “O ewolucji społeczeństw socjalistycznych. Próba wstępnej konceptualizacji”, in: Analizy metodologiczne w nauce, 
genesis of these problems stems from the state-controlled economy and bureaucratization of social life in the interwar period, and from the earlier domination of political life by a single social class, which brought about the serfdom of the peasantry and development of a manorial-serf economy.

eds. Teresa Grabińska and Mirosław Zabierowski (Wrocław: Oficyna Wydawnicza Politechniki Wrocławskiej, 1997), pp. 105-121, Krzysztof Brzechczyn, "The Collapse of Real Socialism in Eastern Europe versus the Overthrow of the Spanish Colonial Empire in Latin America: An Attempt at Comparative Analysis," Journal of Interdisciplinary Studies in History and Archaeology, Vol. 1, No. 2 (2004), pp. 105-133. 



\section{Conclusions}

The present part of the book is devoted to a brief summary of the principal theses put forward in the previous chapters and to a discussion of the main problems resulting from the methodological status of the presented theory.

(1) The process of a cascade is the fundamental concept used in this book. In the process, conceptualized in a conceptual apparatus of the idealizational theory of science, joint influence of secondary factors dominates at some point the impact of the principal factor for a phenomenon under study. The present book uses the concept of a cascade conceptualized in the above way to explain particular courses of history, namely to conceptualize the genesis of developmental dualism in Europe of the 16th-17th centuries.

(2) The book adopts non-Marxian historical materialism as a theory of historical development. I develop n-Mhm to make it capable of capturing fundamental developmental differences between Western and Central Europe. I modify the initial model of socio-economic development, broaden it by the concept of two types of economic revolutions and construct two new models of an economic society: with a surplus or shortage of manpower.

(3) According to the model of a society with a surplus of manpower, which approximates the development of Western-European societies only fragmentarily, the economic situation of direct producers deteriorates and social conflict between the latter and the owners intensifies. In an empirical reality, colonization and settlement on new terrains were the factors, which mitigated these tendencies.

(4) In contrast, according to the model with a shortage of manpower, the economic situation of direct producers improves and the forms of social conflict are mitigated. The settlement with German Law in Central Europe in the 13th and the 14th centuries may be interpreted as an approximation of the above developmental tendencies. However, a further development of Central-European societies stands in contradiction with the developmental tendencies assumed by model III of an economic society. As a result, the development of a manorial-serf economy may be interpreted in terms of deterioration, not improvement of the situation of the peasantry.

(5) The impact of factors present in the cascade of European differentiation, which outweighed the influence of basic developmental mechanisms, is subjected to an empirical analysis. The reconstruction is based on historical works devoted to Central Europe. The shortage of manpower played 
a double role in the cascade of European differentiation. On the one hand, under the conditions of undermined state authority, the low level of population density forced feudal lords to improve the situation of the peasantry in Central Europe. On the other hand, a shortage of manpower hindered the development of the urban sphere. In the phase of social peace in the rural sector of production, the peasantry was not forced to migrate to towns on a massive scale, to improve their economic situation. For this reason, towns in Central Europe were less populated than Western-European towns. The underdevelopment of the urban sphere in the estate monarchies of Central Europe disrupted the social balance between the king, the nobility and burghers. As long as the nobility was not able to fully dominate the state, the urban and peasant economies in these countries came to existence with ease. However, as soon as the nobility gained political superiority in particular Central-European societies, it begun to abolish the privileges of burghers and the freedom of the peasantry. The almost total influence of the nobility on the state allowed the former to confine the development of the alternative urban economic sector and to introduce the so-called second serfdom, which, in turn, enabled an increase of the villein service. The above social processes unfolded within a manorial-serf economy, which arose in connection to the increase of demand on agricultural products in Western Europe. The above-mentioned factors were present in each of the societies under study. Apart from them, the developmental paths of each of the investigated societies had their own characteristic factors.

Now, I would like to ponder on some of the problems resulting from the methodological status of the presented notions and concepts.

(1) The concept of the cascade, similarly to all notions of the idealizational theory of science, has an idealizational status. The concept assumes the presence of interactive links between factors. However, the phenomenon of interdependence of the investigated factors, namely the feedback between the determining and the determined factor is being disregarded. ${ }^{445}$ It is assumed that variables under study are in an isolation.

445 Jerzy Brzeziński, Jolanta Burbelka, Andrzej Klawiter, Krzysztof Łastowski, Sławomir Magala, Leszek Nowak and Włodzimierz Patryas, "Prawo, teoria, sprawdzanie. Przyczynek do marksistowskiej metodologii nauk," in: Teoria a rzeczywistość, ed. Leszek Nowak (Warszawa-Poznań: PWN, 1976), pp. 107-135. 
(2) The presented models assume that the shortage (surplus) of manpower is stable. However, in an empirical reality, the level of population density fluctuated. The assumption of the stability of shortage of workforce does not allow for an analysis of the development of transition societies, which had an intermediate type of economy located between a rent system and a classic manorial-serf demesne.

(3) The factors of shortage and surplus of manpower introduced into a basic model of an economic society. However, model IV of an economic society is in $\mathrm{n}-\mathrm{Mhm}$ an approximation of the history of feudalism. Incorporation of the above-mentioned factors into the model of feudal development would allow for, for instance, investigating the relations between the level of population density and technical advancement.

(4) The concept put forward in the present book was not subjected to the procedure of chronological-territorial specification. As a result, it is assumed that the factors working in the cascade of European differentiation and in its local variants were present throughout the entire period under study (12th-16th/17th centuries) on the entire area occupied by the societies under investigation. Certainly, it is untrue. We may, for example, distinguish specific regions, in which the factors of the cascade of European differentiation did not work at all, or exerted a smaller impact. In Poland, Royal Prussia (1466-1569) was such a region, due to the fact that it had a higher urbanization level and its towns had their participants in the selfgovernmental Prussian Council. Moreover, peasant living in the area owned large farms, which competed with manorial farms for paid workforce. For the above reasons, the development of the nobility's farm based on compulsory serf labor was far less developed in Royal Prussia, in comparison to the remaining parts of the Polish-Lithuanian Commonwealth. 

Appendices 



\section{Appendix 1:}

\section{Civilizational Dimensions of Non-Marxian Historical Materialism ${ }^{446}$}

\section{Introduction}

An argument frequently used to criticize non-Marxian historical materialism states that this theory gives importance to the conflict/antagonistic dimension of a historical process, and almost completely neglects the civilizational dimension. ${ }^{477}$ Very often in this way Leszek Nowak's three-volumed book titled $U$ podstaw teorii socializmu (The Foundation of a Theory of Socialism) was interpreted. ${ }^{448}$ However, Nowak was aware of the significance of the civilizational perspective of a historical process. He argued as follows:

The problem is that social evolution comprises two perspectives - class perspective (referring to economic, political and cultural class) and civilizational perspective (referring to the three areas, respectively). Production is an area of social conflict, but it may also improve human living conditions. Politics is a battlefield for power; however, it may also shape long-lasting institutions, habits and traditions. Culture is an area of rivalry for access to human minds; however, it may also create values. One of the typical forms of ideological thinking is justly described by exclusively focusing on a civilizational perspective; however, this perspective exerts significant influence on social evolution

446 The paper appears in an English translation for the first time. The Polish original: "Wymiar cywilizacyjny nie-Marksowskiego materializmu historycznego. Rekapitulacja dotychczasowych ujęć i próba rozwinięcia” was published in Studia $z$ Filozofii Polskiej, Vol. 8 (2013), pp. 43-53.

447 "Almost" does not equal "completely." The first model of class society included adaptation mechanisms of production organization to the achieved technological level or the influence of technological progress. These civilization factors have been predominantly analyzed with reference to their influence on the dynamics of class conflict, see: Nowak, Property and Power, pp. 78-101.

448 Piotr Przybysz, "Pochwała metody," Czas Kultury, Nos. 1-2 (1992), p. 51. 
and should be considered at some stage of comprehensive development of theoretical construct. $^{449}$

However, lack of more advanced grasp of civilizational perspectives of social life in the present shape of non-Marxian historical materialism does not mean that this theory did not make any attempts to conceptualize this perspective of social life.

The purport of the present essay is to offer a recapitulation and a review of the so-far taken attempts to do so and to indicate a possible development of this theory. Therefore, first, I will modify the typology of social practice. And second, using my typology of societies in non-Marxian historical materialism, I will attempt to match types of class stratification with social practices giving them the best chance of spread. Finally I will explicate the terms of ecological balance and imbalance, and analyze the impact of ecological conditions on the diffusion of various types of class stratification and, indirectly, its their influence on various social practices.

\section{Civilizational Aspects of Non-Marxian Historical Materialism}

The present recapitulation and review limits to two most significant publications and it excludes singular comments present elsewhere. The first was written by Grzegorz Tomczak, the second - by Leszek Nowak. Tomczak analyses the influence of economic collapse on social evolution. He situates economic collapse in the economic-social perspective between crisis - understood as failure to satisfy the historically established social needs - and cataclysm understood as "a violent decrease of the level of means necessary for biological survival."450 The consequence of economic collapse is a decrease of production of the division II (consumer goods) below the threshold of reproduction of workforce. Depending on the duration and tempo, the author has distinguished four types of economic collapse:

- catastrophe - sudden and long-lasting;

449 Leszek Nowak, "Efekt kresowy w procesie historycznym,” in: Marksizm, liberalizm, próby wyjścia, eds. Leszek Nowak and Piotr Przybysz (Poznań: Zysk i S-ka, 1997), p. 310.

450 Grzegorz Tomczak, "The Economic Collapse in Two Models of SocioEconomic Formation," in: Dimensions of the Historical Process, ed. Leszek Nowak (Amsterdam: Rodopi, 1989), p. 259. 
- shock - sudden and short-lasting;

- decline - gradual and long-lasting;

- breakdown - gradual and short-lasting.

Tomczak analyzed in detail the influence of economic decline and catastrophe on the evolution of an economic society (comprising two classes: owners and producers) and a political-economic society (comprising three classes: a class of rulers, a class of owners and a people's class) and concretized relevant models in non-Marxian historical materialism. The most important conclusion emerging from these amendments was the following assertion:

the economic collapse is a factor strengthening the political authority since the occurrence of economic collapse causes an increase of the importance of the coercive measures being at the disposal of the rulers' class. It leads to domination of the political momentum over the economic one which in several variants results in totalitarization [...] It is not a coincidence that [...] totalitarian systems developed in periods of deep economic crises which in the light of hypotheses presented in this paper can be counted to one of the mentioned types of economic collapse. ${ }^{451}$

The second of the aforementioned articles was written by Leszek Nowak who introduced the margin effect to his theory of historical process. This effect is characterized by "actions led by own interests of rivals leads under special circumstances to making the competitive mechanism ineffective; as a result, the former rivals lose contrasting interests and begin to act in line with the common interest." ${ }^{352}$ This situation requires more detailed explanation of social practice.

According to Nowak, social practices have primary conditions (capital), not produced by it, but processed into final conditions (product). The most popular social practice is liberal. It is characterized by unlimited number of participants and maximization of individual goals instead of common goals (community goals). Leszek Nowak argues that totalitarization of social practice means limitation of the number of participants of social practice that its effectiveness decreases. As a result, the problem of exhaustion of resources is solved. Nowak also distinguished solidaristic social practice founded on unlimited number of participants who nonetheless manage to maximize not their individual, but common goals.

451 Tomczak, “The Economic Collapse," p. 269.

452 Nowak, “Efekt kresowy," p. 312. 


\section{Social Practice versus Types of Class Stratification}

I find it important that the two criteria distinguished by Leszek Nowak: the way of realization of a given goal (maximization or optimization) and the number of participants (unlimited or restricted) of social practice are independent from each other. If we cross-examine them, we obtain four, not three types of social practice.

Let us use the term "social practice" to designate a socio-economic practice that predominantly leads to re-shaping of the natural environment. According to the first criterion, it is possible to distinguish social practices that impose limitations on the group of participants and those that do not impose such limitations. According to the second criterion, individuals may maximize their individual goals and satisfy common goals. A contrary situation, in which individuals satisfy their individual goals and maximize common goals, is also possible. When we cross-examine these two criteria, we receive four variants of social practice:

Tab. 2: Typology of social practice

\begin{tabular}{|c|c|c|}
\hline $\begin{array}{l}\text { Number of participants of } \\
\text { social practice/Type of goals } \\
\text { realized }\end{array}$ & Unlimited & Limited \\
\hline$\overline{\text { Individual }}$ & liberal (i) & etatist (ii) \\
\hline Common & solidaristic (iii) & corporate (iv) \\
\hline
\end{tabular}

This allows distinguishing, apart from Leszek Nowak's liberal, solidaristic and etatist social practices, also another type - corporate one. Let's present a characteristic of each type of social practice. The liberal type can be characterized in the following way:

(1) there are no limitations with respect to the group of subjects of the possible social practice;

(2) subjects of the given practice maximize their particular interests (individual or group);

(3) those participants who realize in the most effective way chosen goals (maximization of spiritual domination, profit, power) remain in the further stages of the given social practice.

A historical example of a system founded on the above-described rules to the highest degree is Euro-Atlantic capitalism. The biggest advantage of liberal civilizational evolution is its effectiveness. This effectiveness decreases as 
natural environment resources, that the given social practice is founded on, are close to exhaustion. Then, either the rules of the social practice change, or the practice disappears causing destruction of the social system. The other three types of socio-economic precise are characterized by lower effectiveness. These are: etatist, solidaristic and corporate practice. The etatist practice can be characterized in the following way:

(1) limitations imposed on the group of participants of the social practice;

(2) participants maximize their individual goals;

(3) those participants who realize in the most effective way chosen goals remain in the further stages of the given social practice

A historical example of a system founded on the above-described criteria can be model of triple-lordship society (the co-called real socialism) where triple lords intervenes into economic life and limits effectiveness of economy.

The solidaristic evolution can be characterized in the following way:

(1) no restrictions imposed on the participants of the said social practice;

(2) participants maximize community goals and satisfy individual ones;

(3) those participants who realized in the most effective way chosen goals remain in the further stages of the given social practice.

The above-described type of social practice - as far as we know - has not yet been realized. The corporate social practice can be characterized in the following way:

(1) restrictions imposed on the participants of the said social practice;

(2) participants of the said practice maximize community goals and satisfy individual ones;

(3) those participants who realized chosen goals (maximization community goals and satisfying individual ones) in the most effective way remain in the further stages of the said social practice.

The example of this type of social practice maybe guilds in medieval towns, that decided on the number of liberated apprentices and the scope and price of production of the craft business was decided by the guild that required mandatory participation. Guild regulations were reinforced by family ties, customs and traditions, and religious cult - every guild had a patron.

The above-distinguished social practices are not implemented in a social void, but appear in a certain social context. This context would be best described by a 
presentation of an advanced typology of class stratification in non-Marxian historical materialism. ${ }^{453}$

The above typology hinges on the assumption that class division are not present only in economy but also spontaneously appears in other spheres of human activities, such as politics and culture. On the material level of political life, we can distinguish means of coercion. Relation to them divides society into two groups: the class of rulers that decides about destination of the means of coercion and the class of citizens deprived of this possibility. Economic life has an analogical internal structure. On the material level it is possible to distinguish means of production that establish division into a class of owners and a class of direct producers. In culture, the relation to the means of spiritual production such as printing press, radio, television, etc. - establishes a division into a class of priest who decide on the use of the different kinds of mass media, and the rest of society (a class of believers) devoid of such possibility.

Following from this, the divide of social life allows us to differentiate three separate and autonomous types of class stratification. In politics, the ruling class, which has means of coercion at its command, expands its sphere of regulation at the expense of the autonomy of citizens. In economy, the class of owners maximizes the surplus product at the expense of income of producers. In culture, the class of priests disposing the means of spiritual production deepens their spiritual control and limits the autonomy of the flock. Therefore, social antagonisms founded on unequal access to material social means (of coercion, production and indoctrination) in all three areas of social life have an autonomous character. Class divisions from neighboring spheres of social life may only weaken or strengthen them. Class divisions may also cumulate and the same social class may take control over means of coercion and means of production, or means of coercion and means of spiritual production, in order to reinforce its social power.

The type and level of the accumulation of class divisions is the foundation of typology of societies built in the notion apparatus of non-Marxian historical materialism. The simplified version of this typology is based on the following criteria:

- what type of class interest dominates in a given society;

- what is the level of cumulation of class divisions, namely, whether the dominating class is single, double or triple.

453 Brzechczyn, O wielości linii rozwojowych, pp. 73-86. 
I will now discuss the above-mentioned criteria in detail. In the case of class societies (triple-moment variant) and supra-class societies (in double-moment variant) implementation of criterion (i) leads to distinguishing the dominant class of disposers of the material means of society (rulers, owners and priests). In the case of single-moment societies, where one social class controls the means of coercion, production and indoctrination, implementation of this criterion leads to distinguishing the priority class interest of this triple class of disposers.

The domination of class $A$ over class $B$ means that in the case of conflict between them, in the long-run, the interest of class $A$ is maximized. Therefore, the social class $A$, which dominates over the rest of society this way, is called the principal class. The priority of the class interest of type $A$ over the class interest of type $B$ means that in the situation in which the maximization of the interest of $B$ excludes the maximization of class interest of $A$, in the longrun the interest of $A$ is maximized. In other words, the class interest of $B$ is instrumentally subordinated to the maximization of interest of $A$. The main class interest in a given society realized by the triple class of disposers will be this class interest which has such understood priority over the remaining class interests. Depending on whether the class interest is the maximization of power, profit or spiritual domination as an understood priority in a given society, one may distinguish respectively a political, economic or hierocratical type of society.

The one and the same class of social potentates can merge the disposition over the social means of two (e.g. means of production and means of coercion), or three (e.g. means of production, means of coercion and means of indoctrination) kinds of material means. Therefore respect it is possible to distinguish single (e.g. rulers), double (e.g. rulers-owners) and triple (e.g. rulers-owners-priests) social classes. This is the second criterion of the constructed typology. Depending on the level of the accumulation of class divisions, every social type of society can appear in the single-, double- and triple-moment variants. For example, the principal class may be a single class (triple-moment variant of society), a double class that combines political power with spiritual or economic power (doublemoment variant) or a triple class that merges disposition over means of coercion with disposition over means of production and mass communication (singlemoment variant of society).

Let us now consider relations between the disseminated type of social practice and a type of class stratification. Liberal type of social practice is possible in a triple-moment economic society. Only in this society access to a certain class of owners depends on gaining control over allocation of production forces. As the class of proprietors is domineering, political authorities are unable to impose 
far-reaching limitations on economic practice, and certainly cannot dictate who can be in control of allocation of production forces.

The etatist type of social practice has the best chances of spreading in doubleand single-moment political society. In this social system, the dominating class of rulers seizes control over means of production (by becoming a double class of rulers-owners) and/or of means of indoctrination (by becoming a triple class of rulers-owners-priests) and is able to limit the number of participants of a said social practice.

At the same time, however, the corporate type of social practice has the best chance of diffusion in a double- and triple moment hierocratic or economic society.Top-down corporatization occurs in a hierocratic type of society. In such system, the class of priests is able to limit the number of participants of a socioeconomic practice, allowing only those who accept implementation of common goals, and not individual. Effective limiting of participants of the social practice is possible when priests additionally take control over means of coercion or means production, or both.

Bottom-up corporatization occurs when a class of owners additionally takes control over means of coercion and indoctrination (or enters class alliance with the class of priests). This is exemplified by a medieval guild that rations economic activity and regulates culture, the social life and customs of its owners.

As far as we know, the solidaristic type of social practice has not been spread on a mass scale. Its dissemination requires two conditions. First, it should be a society with three separate classes (three-momentum), so none of the classes would limit the possibilities of social advancement: transition from one class to another. Second, it should be a triple moment hierocratic society: priests impose their worldview on the other members of the society (the flock) in a way that he justifies the domination of communal goals over individual ones. This is all that we can say according with this level of idealization of non-Marxian historical materialism.

To conclude: we could say that the types of social practice distinguished above may be widespread in the following types of class structures:

- liberal - triple-moment economic society;

- etatist - single- and double-moment political society;

- corporate - single- and double-moment hierocratic and/or economic society;

- solidaristic - triple-moment hierocratic society. 


\section{Between Ecological Conditions and Socio-economic Practice}

We should consider, what influences diffusion of a class structure of a certain type. In general, in non-Marxian historical materialism transformation of class structures depends on class mechanisms - results of social revolutions. The victorious people's revolutions directed against the classes of rulers and owners accelerate the accumulation of power and ownership, but the defeated people's revolutions stimulate concessions leading to separation of class divisions.

It is important to take into consideration how diffusion of a class structure of a certain type depends on civilizational mechanisms of social evolution. In order to do so, I will characterize the state of ecological balance and imbalance. According to the definition coined by Jan Kieniewicz:

Ecological balance occurs when the level of social pressure exerted on the environment does not surpass the threshold of resistance, established individually depending on resources and implemented technologies. In other words, the society does not behave or act in a way that causes the environment to transform, which could, in turn, force the society to, for example, implement new technologies reinforcing pressure exerted on the resources of the ecosystem or react in any other way resulting in increasing pressure on the environment. ${ }^{454}$

This idea could also be expressed with the terminology of non-Marxian historical materialism. Let us once more discuss the relation between society and natural environment. It is supposed that are certain initial conditions (resources) of a socio-economic practice, not produced by it, but reshaped in the process of work into certain final conditions - consumable objects.

The state of ecological balance occurs when implementation of a socioeconomic practice does not influence changes of the natural environment that, in turn, enforces significant reshaping of the mode of implementation of the social practice, but allows for stable continuation of a given practice. In the context of ecological balance, a socio-economic practice is implemented without destabilizing the class system.

The state of economic imbalance takes place when implementation of a social practice results in a change of the natural environment, in turn, enforcing a change in the mode of implementation of the social practice. Unchanged continuation of the said social practice would otherwise result in destabilization of the social system followed by its destruction.

The impact of ecological context on socio-economic practice is not exerted directly, but via a type of class stratum. We have a following dependency triad:

454 Jan Kieniewicz, Ekspansja, kolonializm, cywilizacja (Warszawa: DiG, 2008) p. 47. 
Ecological conditions - Class structure - Socio-economic practice

I assume that the dependency relationship between ecological conditions, type of class structure and socio-economic practice are of an adaptive nature. ${ }^{455} \mathrm{We}$ could present them in the following way:

(i) that type of class structure, from a set of historically given types of class structures, becomes adopted on a mass scale which ensures - in certain ecological conditions - the optimal social stability;

(ii) that type of socio-economic practice, from a set of social practices, becomes adopted on a mass scale which ensures - within a certain type of class structure - the optimal interest of the dominant social class.

If in the state of ecological balance, all types of class structure satisfy the criterion of social stability to a similar degree, none of them is favored by ecological conditions. An emergence and diffusion of supra-class or class structures depends mainly on class mechanisms. However, when economic triple-moment class structure appears, a liberal socio-economic practice ensures the highest effectiveness and it will suppress other types of practices. Therefore this kind of practice becomes widespread on a mass scale and economic triple-moment system will become economically superior over alternative supra-class systems. ${ }^{456}$

Differently, the state of ecological imbalance favors social supra-class structures, as only they satisfy the criterion of social stability. The type of goals imposed on individuals and the number of persons allowed independent economic activity limit the effectiveness of the socio-economic practice in a way that does not influence the ecological balance. Paradoxically enough, under the conditions bordering ecological imbalance, a decrease of economic effectiveness increases social stability. An increase of economic effectiveness would result in quicker exhaustion of resources and destabilization of the social system. Therefore, in the context of ecological imbalance, supra-class social structures are shaped of political, hierocratic and economic type, that create favorable conditions for diffusion of socio-economic practices of etatist and corporate type.

455 Nowak, “The Theory of Socio-Economic Formations," pp. 110-121.

456 After Kieniewicz, we should acknowledge the need for distinction of the following terms: the state of "retardation," "stagnation" and "progress" (Kieniewicz, Ekspansja, pp. 114-115). In a paraphrase of my theory, the state of retardation results from imbalanced development of supra-class societies, and stagnation occurs in the context of balanced development. Progress, on the other hand, characterizes balanced development of class societies. 


\section{Appendix II:}

\section{An Individual and Two Approaches toward Political Revolution ${ }^{457}$}

Non-Marxian historical materialism - a theory put forward by Leszek Nowak at the end of 1970s - constitutes one of few approaches toward revolution founded uniquely on political factors. The majority of theories of revolution emphasizes the economic reason and dimensions of these social phenomena.

The above-mentioned theory conceptualizes the mechanism of the outbreak of a political revolution with two approaches - termed by me "sociological" and "anthropological." According to the sociological approach, an outbreak of revolution resulted from the processes of revalorization of autonomous social ties. Differently, according to the anthropological approach, the outbreak of a revolution is a consequence of an extreme increase of control exhorted by the authorities leading, in turn, to a rise of opposition constituted of citizens belonging to a certain category of individuals who refuse to subjugate, even under the most oppressive conditions.

\section{I}

According to the primary sociological approach originating from the end of 1970s, an outbreak of a revolution occurring in the stage of most severe oppression is a response to the revalorization of autonomous social ties. Nowak describes the mechanism as follows:

A long-lasting situation of political oppression leads people to gradually lose their primal sensitivity to danger, causes them to accustom to life under the conditions of political pressure and to habituate to these conditions. They accustom individually, learn how to avoid danger by themselves, and gradually realize that the most effective method of survival under the conditions of political pressure is founded on solidarity

457 The paper appears in English translation for the first time. The Polish original: Jednostka a dwa ujęcia rewolucji w nie-Marksowskim materializmie historycznym was published in: Jednostka w układzie społecznym. Próba teoretycznej konceptualizacji, eds. Krzysztof Brzechczyn, Mieszko Ciesielski, Eliza Karczyńska (Poznań: Wydawnictwo Naukowe WNS UAM, 2013), pp. 85-94. 
and willingness to help others, because every individual (every citizen, not every ruler) can find him/herself in a situation of repression, hence it is in the common interest that every individual is willing to offer help to his/her fellow citizens. As a result, autonomous interpersonal relations that had been dissolved by declassing citizens are being slowly rebuilt. Initially, they rebuilt on the elemental level as mutual help in avoiding individual danger, later, they rebuilt on the level of common undertakings, and finally the process concludes with mass opposition. This process can be described as the rebirth of civil society in a declassed populace leading to the restoration of the ability to fight for their political interests in the most repressed individuals. ${ }^{458}$

The final stage of oppression unfolds as follows:

[S]imultaneously as the ruling class oppresses the society from bottom to top, a process of restitution of human ties takes place in the lowest class, the civil class [...]. The category of citizens most severely oppressed slowly becomes ready to fight with the oppression and, finally, this fight turns into a revolution. It enters a stage of civil freedom. ${ }^{459}$

The thesis based on this model can be expressed in the following way:

Sociological Thesis $\left(\mathbf{S T}^{\star}\right)$. Revolution is a result of processes of revalorization of autonomous social ties taken place within a civil class.

\section{II}

A non-Christian model of man introduced by Nowak in the end of $1980 \mathrm{~s}$ supported the theory of political evolution based on more explicitly anthropological assumptions. According to this new approach, an outbreak of a revolution results from actions of individuals who take a peculiar attitude - an attitude of a revolutionist who refuses to subjugate:

This may be explained by the fact that in this kind of extreme condition, posing a threat of totalization, the social influence is acquired by one of the peculiar attitudes - that of the revolutionaries. When a situation threatens the total elimination of civil society (or the incorporation of the entire society by the structure of enslavement) the revolutionaries, which so far constitute a marginal minority, win support. The attitude of rebellion spreads, until it finally encompasses the masses. We could metaphorically say that the society, endangered by totalization, initiates a defense mechanism - a revolution. ${ }^{460}$

458 Leszek Nowak, Wolność i władza. Przyczynek do nie-Marksowskiego materializmu historycznego (Poznań: NZS AR, 1981), p. 169.

459 Nowak, Wolność i władza, p. 182.

460 Nowak, Power and Civil Society, p. 36. 
The anthropological approach introduced significant corrections to the description of the evolution of the phase of enslavement. Most importantly, the phase of full subjugation cannot be reached, as a civil society, however small, cannot be entirely eliminated. Moreover, the process of enslavement develops the following order: civil masses, servants, lower circles of power:

When the lower ranks of power are totally enslaved, the class of rulers completely exhausts the possibilities of internal expansion. The only way to realize its interests - in the conditions of an isolated society $S$, of a constant level of technology, and so on - is to expand the sphere of regulation at the costs of the remnants of civil society. Social alienation grows even further and reaches the threshold of civil awakening. Finally, the revolution of the second type takes place. ${ }^{461}$

As we can see, the idea of revalorization of autonomous social ties is still present in the static part of the new version of the theory of power, however, it is not put to use in the explanation of the evolution of a political society. Therefore, the thesis of the model can be expressed in the following way:

Anthropological Thesis (AT ${ }^{*}$ ). Revolution is a result of an extreme increase of civil alienation causing resistance of citizens belonging to a peculiar category of a civil class.

To conclude: there are two approaches toward the model of revolution in the theory of political society. The first, "sociological" approach explains the outburst of a revolution with the mechanisms of revalorization of autonomous civil ties. The second, "anthropological" approach discusses the impact of a certain peculiar category of citizens rejecting enslavement. The difficulty with accommodating the two mechanisms lays in the definition of the role of the revolutionists in the process of revalorization of independent social ties.

\section{III}

The two concepts of the model of revolution were developed without taking the problem of accommodation of the two mechanisms into consideration the following critical analyses: the sociological and the anthropological approach. ${ }^{462}$ The latter essay predominantly questioned the idea of dissemination of revolutionary approach within the conditions of enslavement. According to anthropological approach:

461 Nowak, Power and Civil Society, p. 60.

462 Krzysztof Brzechczyn, "Civil Loop and Absorption of Elites," in: Social System, Rationality and Revolution, eds. Leszek Nowak and Marcin Paprzycki (Amsterdam: Rodopi, 1993), pp. 277-283. 
the core of the author's [Nowak's] explanation relies on the fact that in the enslaved society, people will suddenly come to accept revolutionary ideas. The question, how does the society come out from enslavement? Is thus replaced by the question: How is it possible for revolutionary ideas to spread among enslaved people? The latter question does not have a clear answer. In an almost totalized society, most people are enslaved; they love their oppressors. [...] A person who is inclined to respond benevolently to a mean act of another will have to explain this phenomenon to himself and to others. And what better explanation is there than to claim - and believe - that one loves one's malefactor? Consequently, if a given citizen is enslaved he will reject revolutionary ideas as endangering his vision of the world. ${ }^{463}$

Paprzycka and Paprzycki conclude their argument with the following statement:

Nowak's reasoning leads to a dilemma: are the individuals who respond to revolutionist ideas not-subjugated and able to raise against their oppressors, or - as Nowak seems to assume - are they enslaved, but the nature of subjugation contains a mechanism, associated with influence by others, allowing them to escape enslavement. ${ }^{464}$

In their unfolding of the second alternative Paprzycka and Paprzycki offer a differentiation into two types of approach: of an intellectual and of a simple person. The approach of an intellectual is characterized by an ability to explain and justify every possible situation, including his/her own nonexistence. A simple person is deprived of such abilities; he/she applies common-sense knowledge and divides the world into good and evil. ${ }^{465}$ In general, the resistance line of an intellectual is compatible with the approach of an individual belonging to $\mathrm{n}-\mathrm{Cmm}$. An intellectual is capable of explaining and justifying everything, including selfenslavement. A simple person, on the contrary, accepts subjugation as long as he/she is capable of justifying it. Her/his abilities of self-delusion are limited, at some point he/she decides to revolt. According to Paprzycka and Paprzycki:

Given the fact that the majority of the society is comprised by simple people (most so-called intellectuals are simple in this sense), the phenomenon of revolution of the second type can be explained. When the level of civil alienation passes beyond the area of enslavement, the global level of resistance will increase because simple people will rise from enslavement into the area of the second rebellion. The rebellion will due to them and to a few revolutionaries. The majority of the intellectuals will be still enslaved. It is thus to the simplicity and down-to-earthness of simple people that the society owes its defense mechanism. It is small wonder then that it is precisely the simple people who have the power to move the social gears. ${ }^{466}$

463 Paprzycka, Paprzycki, “How Do Enslaved People,” p. 255.

464 Paprzycka, Paprzycki, "How Do Enslaved People,” p. 80.

465 Paprzycka, Paprzycki, “How Do Enslaved People," pp. 260-261.

466 Paprzycka, Paprzycki, “How Do Enslaved People,” p. 261. 
The anthropological thesis, as corrected by Paprzycka and Paprzycki, can be expressed in the following way:

$\mathrm{AT}^{* *}$ : revolution is a result of an extreme increase of civil alienation that causes members of a civil class without the ability of self-delusion to revolt.

Noteworthy, Paprzycka and Paprzycki criticize and modify only the static part of the theory under analysis. They omit the question of how, if at all, the introduction of the social category of a simple person impacts subsequent stages of political evolution. I find this highly regrettable. The authors assume that simple persons constitute the majority of a society. If this is the case, why does a visible social minority participate in a revolution? Moreover, if a revolution of simple persons results from their inability to deceive themselves, then the process of liberation would be unfolding in a reversed order. The first revolution, initiating the phase of cyclic declassation, would be mainstream, as at that point the system of enslavement is the most oppressive and provides more occasions to "self-delude." Subsequently, under the influence of lost revolutions, the system gradually softens and provides fewer occasions to self-deceit. Hence, there would be fewer rebellious simple persons. However, in reality, we have an opposite situation. The first revolution is not mass and the following revolutions, erupting as the system softens and becomes more morally acceptable, are mainstream.

\section{IV}

There are further questions to be posed with reference to the development of both approaches to revolution. The sociological approach does not provide answers to the following questions: why does revalorization of autonomous social ties happen? How does terror influence the process of revalorization of autonomous civil ties? And the anthropological model does not provide answers to the question: what happens when revolutionists had been eliminated? I will answer the first question by using Nowak's modified differentiation between action and network of social relations within which action takes place. The definition offered by Nowak satisfies the following postulates:

- all actions of a certain type are undertaken within a suitable network of social relations;

- an individual exerts no influence on this social network; however, he/she can refrain from undertaking actions within the network, but others will undertake those actions; 
- the structure can be modified only with a mass action resulting in substitution of one network of social ties with another;

- persistency of a network of social relations is measured by a number of actions undertaken within it. ${ }^{467}$

All actions are undertaken within a network of social ties. Actions undertaken under the conditions of freedom are undertaken within a network of autonomous social ties. Actions controlled by the authorities are undertaken within a network of state-controlled social ties.

Let us introduce a concept of higher and lower, respectively, level of effectiveness of a network of social ties. Let us assume that the network of social ties $S_{1}$ is more effective than the network of social ties $S_{2}$ when the pursuit of action $D_{1}$ within the network of social ties $S_{1}$ requires less time, input and undertakings essential to complete the said action in comparison with the action $D_{2}$ undertaken within the alternative network of social ties $S_{2}$. This example allows us to answer the question of when a tendency to revalorize autonomous network of social ties occurs in a society.

The progressing bureaucratization of social life causes a decrease of effectiveness of state-controlled social ties. The increasing number of required stamps, signatures and seals prolongs the time of completion of an action within the framework of a bureaucratized social structure, and increases the input and number of actions essential to complete the action. The progressing bureaucratization of social ties causes the autonomous network of social ties to be more effective, in comparison to the bureaucratized network, and chosen for an increasing number of actions to be undertaken within it.

Example: The results of the research on informal economy in Peru conducted by Instituto Libertad y Democracia (ILD) directed by Hernando de Soto constitutes a suitable illustration for this situation. ${ }^{468}$ The ILD research team divided costs of functioning within formal structures into two categories of costs of access and costs of survival. The research team set up a small industrial plant in Lima in the summer of 1983 and took efforts to register the enterprise. During the registration procedure the representatives of the company had been approached ten times with a demand to pay a bribe in order to facilitate the registration, and they were twice forced to pay it. The conduced experiment proved that in order to receive 11 required concessions

467 Nowak, Power and Civil Society, pp. 30-31.

468 Hernando de Soto, Inny szlak. Niewidzialna rewolucja w Trzecim Świecie (Warszawa: Polskie Towarzystwo Współpracy z Klubem Rzymskim, 1991), pp. 202206, 22-224. 
an individual with an average income has to devote 289 working days to administrative procedures. In general, the costs of registration amounted to $\$ 1231$, which equals Peru's 32 average monthly wages. It is noteworthy that during the 289 -dayslong registration procedure leading to acquisition of the necessary 11 independent concessions, the administrative authorities did not realize that they are dealing with a fictional company. After it received a legal status, the enterprise had to continue covering the costs of functioning within a formal economy. The ILD research team divided these costs into three categories: costs associated with taxes, legal tax burdens and general costs of services associated with the public sector. According to the estimation, $21.7 \%$ of costs fall into the first category, $72.7 \%$ - to the second category and $5.6 \%$ - to the third category. ${ }^{469}$ The costs of survival of a small industrial plant constitute $347 \%$ of income and $11.3 \%$ of production costs. In order to calculate the time required to meet the demands imposed by the administration, ILD conducted research in 37 legal companies operating in various fields. It concluded that administrative employees of these companies devote around $40 \%$ of their time to fulfil the obligations imposed by the administration. In Peru of the 1980s, the costs of operation within formal structures turned out to be significantly higher than the costs of operation within informal structures (bribes, lack of access to bank loans), therefore, informal businesses have flourished and amounted for the majority of the country's gross national product.

The introduced modification allows for two observations. First, not all autonomous social ties are more effective than the state social ties. For example - apart from unique cases - state is more effective in fighting organized crime in comparison to citizens operating within bottom-up initiatives. Authorities usually prove to be more effective in the areas of defense policy and foreign policy. Hence, the process of revalorization of autonomous social ties does not cover all spheres of social life, and only those where autonomous social ties prove to be more effective. Therefore, a full boycott of the state, against the ideas of Polish anarchist, Edward Abramowski, is impossible, as state social ties - controlled by social minorities armed with coercive measures - are more effective in some areas of social life, than autonomous social ties.

Moving onto the second question: the process of restitution of independent social ties predominantly depends on the magnitude and severity of repressions implemented by rulers, and not only on the persistency of subjugation imposed on a society. The less violent the political terror implemented by the authorities,

469 Soto, Inny szlak, p. 223. 
the shorter the process of revalorization of autonomous social ties. As political terror intensifies, the process of revalorization of autonomous social bonds becomes longer. In extreme cases, the process of restitution of independent social ties can block. This situation could be dubbed a civil collapse. The evidence indicates that Cuban and North-Korean societies remain in such situation, where the omnipotence of a party causes long-lasting social lifelessness. A stage of enslavement may conclude with a civil collapse or with a restitution of autonomous social ties. At this point we do not know which of the two options develops.

We are capable of doing so, to some extent, by basing the theory of power on the anthropological concept of a non-Christian model of man, as the category of revolutionists constitutes one of its peculiar categories. Revolutionists are individuals who, regardless of the amount of experienced wrongdoing, do not acquire an attitude of pathological benevolence toward their oppressor, and do not allow him/her to subjugate them. Their actions lead to the restitution of autonomous social ties. Regardless of the amount of repressions implemented by the authorities, these individuals do not "crack" and continue to resist, by initiating processes of revalorization of independent social ties. A society does not enter a permanent state of civil collapse, due to the presence of the representatives of this social category. Consequently, the sociological approach toward revolution corrected with the anthropological addendum of social processes can be expressed in the following way:

ST $^{* *}$ : revolution is a result of processes of revalorization of autonomous social ties initially occurring among the members of the civil class characterized by a revolutionary attitude.

Accordingly, two factors result in an outburst of a revolution: the presence of a sufficient number of steadfast members of a society and the level of their organizational skills leading to their cooperation. After taking both approached into consideration - the anthropological and the social one, I have determined the course of enslavement in the following way: after the suppression of the revolution of the first kind, terror is introduced and destroys autonomous social ties, which, in turn, allows the authorities to increase the control zone to maximum without causing a rebellion of citizens. As soon as the authorities control all spheres of social life, the system reaches the state of totalitarianism. At this stage of evolution there are no antonymous social ties open to subjugation. As the mechanisms of power struggle continue to force a typical ruler to broaden his/her control zone, they result in political rivalry influencing the spheres of social life subjugated to other members of the ruling class. Initially, the power 
spheres subjugated to servants are subject to political rivalry. Afterwards, the rivalry moves onto the power spheres of other rulers. The course of subjugation is as follows: initially, citizens are subject to control by the authorities; afterwards, servants; finally, lower circles of power. This situation threatens to destroy the entire political system. It can be supported only with purges eliminating the surplus of candidates to power and allowing for further enslavement of social spheres abandoned by them. At this stage of social evolution, the periodical waves o terror, directed against the members of power structures, break the periods of totalitarianism.

I find it noteworthy to emphasize that this corrected course of the phase of enslavement assumes the possibility to entirely eliminate civil society. Would this be a permanent state, or does it depend on the presence of revolutionists within the civil class? We cannot exclude a possibility of a course of evolution of political society where rulers eliminate revolutionists beforehand, i.e. during a post-revolution terror. In this case, we would have an answer to the third question: absence of the social category of revolutionists leads to a situation where the process of revalorization of independent social ties does not begin, and a society remains stuck in a future-less civil collapse.

If this situation luckily does not happen, the process of revalorization of social ties independent from authorities begins. Initially, the phenomena are initiated by the category of revolutionists - individuals who resist subjugation. An increase of the capability of the civil class to revolt leads to a civil revolution of the second type, ended with defeat and forcing the authorities to implement concessions purported to prevent similar situation from happening in the future. As a result, the sphere of civil autonomy increases, ending the self-enslavement of the authorities that gain new areas of social life to be placed under control. 



\section{List of Figures}

Fig. 1: The power of influence of factors $H$ and $p$ on $F$. ............................. 95

Fig. 2: The order of the power of influence of the factors $H, A, B, C, D$,

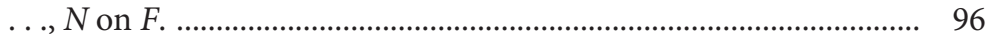

Fig. 3: Structure of the idealizational theory of science. .............................. 116

Fig. 4: Two types of essential structures. ....................................................... 148

Fig. 5: A cascade process; ........................................................................... 151

Fig. 6: Basic types of societies in non-Marxian historical materialism. .... 175

Fig. 7: The dependence of the level of the class struggle of the citizenry on civil alienation ................................................................................. 178

Fig. 8: An evolution of a purely political society. ........................................ 181

Fig. 9: The dependency of the level of class struggle on the alienation of labor. ................................................................................................ 208

Fig. 10: Development of an economic society (the standard no-loop variant).

Fig. 11: Development of an economic society. Confrontational variant of a defeat.

Fig. 12: Development of an economic society: a single labor loop variant. 213

Fig. 13: Non-rationalistic model of man. ........................................................ 222

Fig. 14: Relation power - civil society. ........................................................... 226

Fig. 15: The dependency of the level of class struggle on the alienation of labor.

Fig. 16: Two types of revolution in the development of an economic society.

Fig. 17: Social resistance of the unemployed. 241

Fig. 18: The dependency of the intensity of class struggle on the alienation of labor of the employed strata of the class of direct producers.

Fig. 19: The dependency of the intensity of class struggle on the alienation of labor in a society with a surplus of manpower.

Fig. 20: Development of an economic society with surplus workforce. ....... 248

Fig. 21: Dependency between the intensity of economic class struggle and the alienation of labor in a society with a shortage of manpower.

Fig. 22: Evolution of an economic society with a shortage of manpower.

Fig. 23: The core of the cascade of European differentiation. 285 
Fig. 24: The Polish variant of the cascade of developmental differentiation.

Fig. 25: The Hungarian variant of the cascade of developmental differentiation.

Fig. 26: The Bohemian variant of the cascade of European differentiation. 


\section{List of Tables}

Tab. 1: Types of substantial philosophies of history ...................................... 34

Tab. 2: Typology of social practice ……………............................................ 332 



\section{Bibliography}

\section{Methodological and Theoretical Works}

Ackoff, Russell L. with the collaboration of Shiv K. Gupta and J. Sayer Minas. Scientific Methods: Optimizing Applied Research Decision. New York and London: John Wiley \& Sons, Inc., 1962.

Atkinson, Ronald Field. Knowledge and Explanation in History. An Introduction to the Philosophy of History. Ithaca: Cornell University Press, 1978.

Augustine of Hippo. The City of God. Transl. Marcuse Dods. Overland Park: Digireads.com Publishing, 2017.

Banaszak, Tomasz. "Problem autokratyzacji ustroju demokratycznego" [The Problem of Autocratization of the Democratic System]. In: Marksizm, liberalizm, próby wyjścia, eds. Leszek Nowak and Piotr Przybysz. Poznań: Zysk i S-ka, 1997, pp. 381-399.

Benton, Ted and Ian Craib. Philosophy of Social Science: Philosophical

Foundations of Social Thought. New York/Basingstoke: Palgrave, 2001.

Berlin, Isaiah. "Historical Inevitability." In: Isaiah Berlin, Liberty, ed. Henry Hardy. New York: Oxford University Press, [1949] 2002, pp. 94-165.

Berlin, Isaiah. "Political Ideas in the Twentieth Century." In: Isaiah Berlin, Liberty, ed. Henry Hardy. New York: Oxford University Press, [1949] 2002, pp. 55-93.

Bonnell, Victoria E. "The Uses of Theory, Concepts and Comparison in Historical Sociology." Comparative Studies in Society and History, Vol. 22, 1980, pp. 156-175.

Borbone, Giacomo. "Leszek Nowak and Idealizational Approach to Science." Linquistic and Philosophical Investigations, Vol. 10, 2011, pp. 125-149.

Borbone, Giacomo. “The Legacy of Leszek Nowak.” Epistemologia, Vol. 34, No. 2, 2012, pp. 227-252;

Borbone, Giacomo. Questioni di metodo. Leszek Nowak e la scienza come idealizzazione. Roma: Acireale, 2016.

Bratkiewicz, Jarosław. Teoria przedkapitalistycznej formacji społecznej w kulturach orientalnych. Interpretacja badan i polemik [The Theory of precapitalist social formation in oriental cultures. Interpretation of research and polemics]. Wrocław: Ossolineum, 1989.

Brzechczyn, Krzysztof. "Between Science and Literature. The Debate on the Status of the History." In: Idealization XIII: Modeling in History. Poznań 
Studies in the Philosophy of the Sciences and the Humanities, Vol. 97, ed. Krzysztof Brzechczyn. Amsterdam/New York: Rodopi, 2009, pp. 7-30. Brzechczyn, Krzysztof. "Civil Loop and the Absorption of Elites." In: Social System, Rationality and Revolution. Poznań Studies in the Philosophy of the Sciences and the Humanities, Vol. 33, eds. Leszek Nowak and Marcin Paprzycki. Amsterdam - Atlanta, GA: Rodopi, 1993, pp. 277-283.

Brzechczyn, Krzysztof. "How Do Narratives Explain? A Comment from the Point of View of Poznań School of Methodology." In: Towards a Revival of Analytical Philosophy of History. Around Paul A. Roth's Vision of Historical Sciences. Poznań Studies in the Philosophy of Sciences and the Humanities, Vol. 110, ed. Krzysztof Brzechczyn. Leiden/Boston: Brill/Rodopi, 2018, pp. 148-165.

Brzechczyn, Krzysztof. "Jednostka a dwa ujęcia rewolucji w nie-Marksowskim materializmie historycznym" [An Individual versus Two Approaches towards Political Revolution in non-Marxian Historical Materialism]. In: Jednostka w układzie społecznym. Próba teoretycznej konceptualizacji, eds. Krzysztof Brzechczyn, Mieszko Ciesielski, and Eliza Karczyńska. Poznań: Wydawnictwo Naukowe WNS UAM, 2013, pp. 85-94.

Brzechczyn, Krzysztof. "Miejsce metody porównawczej w teorii rewolucji Thedy Skocpol. Próba eksplikacji w aparaturze pojęciowej idealizacyjnej teorii nauki" [The Place of Comparative Method in Theda Skocpol's Theory of Revolution: An Attempt an Explication within the Conceptual Framework of Idealizational Theory of Science]. Filozofia Nauki, Vol. 24, No. 4, 2016, pp. 49-72.

Brzechczyn, Krzysztof. “O ewolucji społeczeństw socjalistycznych. Próba wstępnej konceptualizacji” [On the Evolution of Socialist Societies. An Attempt at a Preliminary Conceptualization]. In: Analizy metodologiczne w nauce, eds. Teresa Grabińska and Mirosław Zabierowski. Wrocław: Oficyna Wydawnicza Politechniki Wrocławskiej, 1997, pp. 105-121.

Brzechczyn, Krzysztof. O wielości linii rozwojowych w procesie historycznym. Próba interpretacji ewolucji społeczeństwa meksykańskiego [On the Multitude of Developmental Paths in a Historical Process. An Attempt at an Interpretation of the Evolution of a Mexican Society]. Poznań: Wydawnictwo Naukowe UAM, 2004.

Brzechczyn, Krzysztof. "Rozwój teorii rewolucji w socjologii historycznoporównawczej. Próba analizy metodologicznej" [Development of the Theory of Revolution in Historical-Comparative Sociology. An Attempt at a Methodological Analysis]. In: O rewolucji. Obrazy radykalnej zmiany społecznej, eds. Krzysztof Brzechczyn and Marek Nowak. Poznań: Wyd. Nauk. IF UAM, 2007, pp. 37-64. 
Brzechczyn, Krzysztof. "Strategies of Comparative Analysis in Historical Comparative Sociology: An Attempt at an Explication within the Conceptual Framework of the Idealizational Theory of Science." In: Idealization XIV: Models in Science. Poznan Studies in the Philosophy of the Sciences and the Humanities, Vol. 108, eds. Giacomo Borbone and Krzysztof Brzechczyn. Leiden- Boston: Brill/Rodopi, 2016, pp. 184-201.

Brzechczyn, Krzysztof. Ścieżki transformacji. Ujęcia teoretyczne i opisy empiryczne. Poznań: Zysk i S-ka, 2003.

Brzechczyn, Krzysztof. “Tajna policja polityczna w systemie totalitarnym. Próba modelu." In: W stronę antropologii bezpieki. Nieklasyczna refleksja nad aparatem bezpieczeństwa $w$ Polsce Ludowej [Secret Political Police in a Totalitarian System. An Attempt at a Model], eds. Jaroslaw Syrnyk, Agnieszka Klarman, Marcin Mazur, and Eugeniusz Kłosek. Wrocław: IPN, 2014, pp. 31-50.

Brzechczyn, Krzysztof. “The Collapse of Real Socialism in Eastern Europe versus the Overthrow of the Spanish Colonial Empire in Latin America: An Attempt at Comparative Analysis." Journal of Interdisciplinary Studies in History and Archaeology, Vol. 1, No. 2, 2004, pp. 105-133.

Brzechczyn, Krzysztof. "The State of the Teutonic Order as Socialist Society.”

In: Social System, Rationality and Revolution. Poznan Studies in the Philosophy of the Sciences and the Humanities, Vol. 33, eds. Leszek Nowak and Marcin Paprzycki. Amsterdam - Atlanta, GA: Rodopi, 1993, pp. 397-417.

Brzechczyn, Krzysztof. "Unsuccessful Conquest and Successful Subordination.

A Contribution to the Theory of Intersocial Relations." In: Social System, Rationality and Revolution. Poznań Studies in the Philosophy of the Sciences and the Humanities, Vol. 33, eds. Leszek Nowak and Marcin Paprzycki. Amsterdam - Atlanta, GA: Rodopi, 1993, pp. 445-456.

Brzechczyn, Krzysztof. "Wymiar cywilizacyjny nie-Marksowskiego materializmu historycznego. Rekapitulacja dotychczasowych ujęć i próba rozwinięcia" [Civilizational Dimensions of Non-Marxian Historical Materialism: A Recapitulation of the Former Approaches and an Attempt at their Development] Studia z Filozofii Polskiej, Vol. 8, 2013, pp. 43-53.

Brzechczyn, Krzysztof. “Zwycięska rewolucja i przegrana modernizacja. Próba parafrazy teorii rewolucji społecznych Thedy Skocpol w aparaturze pojęciowej nie-Marksowskiego materializmu historycznego" [A Victorious Revolution and a Lost Modernisation. An Attempt at a Paraphrase of Theda Skocpol's Theory of Social Revolutions in the Conceptual Apparatus of nonMarxian Historical Materialism]. In: Jednostka w układzie społecznym. Próba 
teoretycznej konceptualizacji, eds. Krzysztof Brzechczyn, Mieszko Ciesielski, and Eliza Karczyńska. Poznań: WN WNS UAM, 2013, pp. 223-252.

Brzechczyn, Krzysztof, Mieszko Ciesielski, and Eliza Karczyńska, eds. Jednostka w układzie społecznym. Próba teoretycznej konceptualizacji. Poznań: Wyd. Naukowe WNS UAM, 2013.

Brzeziński, Jerzy. "Interaction, Essential Structure, Experiment." Poznań

Studies in the Philosophy of the Sciences and the Humanities, Vol. 1, 1975, pp. 43-58.

Brzeziński, Jerzy. Struktura procesu badawczego w naukach behawioralnych

[A Structure of a Research Process in the Behavioural Sciences]. Warszawa Poznań: PWN, 1976.

Brzeziński, Jerzy, Jolanta Burbelka, Andrzej Klawiter, Krzysztof Łastowski, Sławomir Magala, Leszek Nowak, and Włodzimierz Patryas. "Prawo, teoria, sprawdzanie. Przyczynek do marksistowskiej metodologii nauk" [Law, Theory, Validation. A Contribution to the Marxian Methodology of Sciences]. In: Teoria a rzeczywistość, ed. Leszek Nowak. Warszawa-Poznań: PWN, 1976, pp. 107-135.

Brzeziński, Jerzy and Krzysztof Łastowski, eds. Filozoficzne i metodologiczne podstawy teorii naukowych [Philosophical and Methodological Foundations of Scientific Theories]. Poznań: PWN, 1989.

Brzeziński, Jerzy and Leszek Nowak, eds. Idealization III. Approximation and Truth. Poznań Studies in the Philosophy of Sciences and the Humanities, Vol. 25. Amsterdam - Atlanta, GA: Rodopi, 1992.

Buczkowski, Piotr. "Toward a Theory of Economic Society. An Attempt of at the Adaptive Interpretation." In: Social Classes Action and Historical Materialism. Poznań Studies in the Philosophy of the Sciences and the Humanities, Vol. 6, ed. Leszek Nowak. Amsterdam-Atlanta GA: Rodopi, 1978, pp. 158-210.

Buksiński, Tadeusz. "Czy historia ma sens?” [Does History Make Sense?]. In: Zaproszenie do filozofii. Wykłady z filozofii dla młodzieży, eds. Krzysztof Łastowski and Paweł Zeidler. Poznań: Humaniora, 2001, pp. 99-115.

Chwalisz, Piotr, "Stałe w teorii idealizacyjnej" [Constants in the Idealizational Theory]. In: Odkrycie, abstrakcja, prawda, empiria, historia a idealizacja, eds. Andrzej Klawiter and Leszek Nowak. Warszawa-Poznań: PWN, 1979, pp. 99-104.

Ciesielski, Mieszko. "Leszek Nowak's non-Christian Model of Man and Inderdisciplinarity of Humanities." Studia Europea Gnesnensia, No. 7, 2013, pp. 87-111.

Ciesielski, Mieszko. "Problem kumulacji podziałów klasowych we współczesnym kapitalizmie. Próba interpretacji teoretycznej” [The Problem 
of Accumulation of Class Divisions in Modern Capitalism. An Attempt at a Theoretical Interpretation]. In: Jednostka $w$ układzie społecznym. Próba teoretycznej konceptualizacji. eds. Krzysztof Brzechczyn, Mieszko Ciesielski, and Eliza Karczyńska. Poznań: Wyd. Naukowe WNS UAM, 2013, pp. 131-152.

Ciesielski, Mieszko. Zagadnienie ograniczeń racjonalnego modelu działań ludzkich, Próba ujęcia działania nawykowo-racjonalnego [The Issue of Limitation of the Rational Model of Human Behaviour. An Attempt at Recognition of Habitual/Rational Behaviour]. Poznań: Wydawnictwo Poznańskie, 2012.

Cohn, Norman. Cosmos, Chaos and the World to Come. The Ancient Roots of Apocalyptic Faith. London: Yale University Press, 2001.

Collins, Randall. Macrohistory. Essays in Sociology of the Long Run. Stanford: Stanford University Press, 1994.

Coniglione, Francesco. Realta e astrazione. Scuola polacca ed epistemologia postpositivistica. Roma: Acireale/Bonnano, 2008.

Czajkowski, Waldemar. "Kilka uwag o Leszka Nowaka nie-Marksowskim materializmie historycznym i Andre G. Franka teoriach systemu światowego" [Remarks on Leszek Nowak's non-Marxian historical materialism and Andre G. Frank's theories of the world system]. In: Jednostka w układzie społecznym. Próba teoretycznej konceptualizacji, eds. Krzysztof Brzechczyn, Mieszko Ciesielski, and Eliza Karczyńska. Poznań: Wyd. Naukowe WNS UAM, 2013, pp. 187-206.

Danto, Arthur. Analytical Philosophy of History. Cambridge: Cambridge University Press, 1965.

Domańska, Ewa. “On Various Ends of History." Journal of the Interdisciplinary Crossroads, Vol. 1, No. 2, 2004, pp. 283-292.

Domar, Evsey D. "The Causes of Slavery or Serfdom: A Hypothesis." The Journal of Economic History, No. 30, 1970, pp. 18-32.

Egiert, Robert. "Toward the Sophisticated Rationalistic Model of Man." In: Social System, Rationality and Revolution. Poznan Studies in the Philosophy of the Sciences and the Humanities, Vol. 33, eds. Leszek Nowak and Marcin Paprzycki. Amsterdam: Rodopi, 1993, pp. 215-233.

Fukuyama, Francis. The End of History and the Last Man. New York: The Free Press, 1992.

Fuliński, Andrzej. "O chaosie i przypadku. A także o determinizmie, redukcjonizmie i innych grzechach fizyków, czyli o zmianach w obrazie świata widzianych okiem jednego z nich" [On Chaos and Chance. And about Determinism, Reductionism and other Sins of the Physicists, or about 
the Changes in the Image of the World as seen by One of Them]. Znak, No. 5(456), 1979, pp. 31-50.

Gadamer, Hans George. "Is There a Causality in History?” In: Hermeneutics between History and Philosophy: Selected Writings, Vol. 1. Transl. Pol Vandevelde and Arun Iyer. London: Bloomsbury Academic, 2016, pp. 3-12.

Garcia de la Sienra, Adolfo. "The Christian Model of Man: Reply to Nowak." Social Theory and Practice. An International and Interdisciplinary Journal of Social Philosophy, Vol 15, No.1, 1989, pp. 89-107.

Gawor Leszek. Katastrofizm konsekwentny. O pogladach Marian Zdziechowskiego i Stanislawa Ignacego Witkiewicza [Consequent Catastrophism. On the Views of Marian Zdziechowski and Stanislaw Ignacy Witkiewicz]. Lublin: Wyd. UMCS, 1998.

Gellner, Ernest. Sword, Plough and Book. Structure of Human History. Chicago: University of Chicago Press, 1989.

Ghosh, Kenneth. "Some Theories of Universal History." Comparative Studies in Society and History, Vol. 7, 1964, pp. 1-20.

Grabski, Andrzej Feliks. Kształty historii [Forms of History]. Łódź: Wydawnictwo Łódzkie, 1985.

Hall, John A. Powers and Liberties. The Causes and Consequences of the Rise of the West. Los Angeles: University of California Press, 1985.

Hamminga, Bert and Neil De Marchi, eds. Idealization VI: Idealization in Economics. Poznań Studies in the Philosophy of Sciences and the Humanities, Vol. 38. Amsterdam-Atlanta, GA: Rodopi, 1994.

Handelsman, Marceli. "Possibilities and Necessities of the Historical Process." In: Idealization XIII: Modelling in History. Poznań Studies in the Philosophy of the Sciences and the Humanities, Vol. 97, ed. Krzysztof Brzechczyn. Amsterdam/New York: Rodopi, 2009 [1931], pp. 33-42.

Holton, Robert J. Cities, Capitalism and Civilization. London: Allen Unwin, 1986.

Hornowska, Elżbieta. "A Certain Approach to Operationalization."

In: Idealization II: Forms and Application. Poznań Studies in the Philosophy of the Sciences and the Humanities, Vol. 17, eds. Jerzy Brzeziński, Francesco Coniglione, T.A.F. Kuipers, and Leszek Nowak. Amsterdam-Atlanta: Rodopi, 1990, pp. 77-86.

Hornowska, Elżbieta. Operacjonalizacja wielkości psychologicznych. Założenia

- Struktura - Konsekwencje [The Operationalization of Psychological Magnitudes. Assumptions - The Structure - Consequences]. Wrocław: Ossolineum, 1989. 
Huntington, Samuel. The Clash of Civilizations and the Remaking of World Order. New York: Penguin Books, 1997.

Kalberg, Stephen. Max Weber's Comparative Historical Sociology. Cambridge: Polity Press, 1994.

Kieniewicz, Jan. Ekspansja, kolonializm, cywilizacja [Expansion, Colonialism, Civilisation]. Warszawa: DiG, 2008.

Klawiter, Andrzej. "Adaptation and Competition. A Contribution to the Classification of Adaptive Relationships." In: Dimensions of the Historical Process. Poznań Studies in the Philosophy of the Sciences and the Humanities, Vol. 13, ed. Leszek Nowak. Amsterdam-Atlanta, GA: Rodopi, 1989, pp. 129-146.

Klawiter, Andrzej. "Teoria formacji społecznej w materializmie historycznym" [The Theory of Social Formation in Historical Materialism]. In: Założenia materializmu historycznego, ed. Leszek Nowak. Warszawa-Poznań: PWN, 1978, pp. 233-258.

Klawiter, Andrzej, Krzysztof Łastowski, Leszek Nowak, and Wojciech Patryas. "Adaptation, Learning, Praxis. Some Applications of the Adaptive Conceptual Apparatus." In: Dimensions of the Historical Process. Poznań Studies in the Philosophy of the Sciences and the Humanities, Vol. 13, ed. Leszek Nowak, Amsterdam-Atlanta, GA: Rodopi, 1989, pp. 121-128.

Klawiter, Andrzej and Leszek Nowak, eds. Odkrycie, abstrakcja, prawda, empiria, historia a idealizacja [Discovery, Abstraction, Truth, Empirical Experience, History, and Idealization]. Warszawa-Poznań: PWN, 1979.

Klein, Lawrence R. An Introduction to Econometrics. Englewood Cliffe: Prentice Hall, 1962.

Kochanowicz, Jacek. “Teoria ekonomiczna... w oczach krytyków” [Economic Theory. . . in the Eyes of Critics]. In: Witold Kula, Teoria ekonomiczna ustroju feudalnego. Warszawa: Książka i Wiedza, 1983, pp. 247-270.

Kuderowicz, Zbigniew. Filozofia dziejów [Philosophy of History]. Warszawa: Wiedza Powszechna, 1983.

Kula, Witold. An Economic Theory of the Feudal System. Towards a Model of Polish Economy, 1500-1800. Transl. Lawrence Garner. London: NLB, 1976.

Lamentowicz, Wojciech. "Kilka uwag polemicznych" [A Handful of Polemical Remarks]. In: Leszek Nowak, Władza. Próba teorii idealizacyjnej, Warszawa: In Plus, 1988, pp. 184-191.

Lange, Matthew. Comparative-Historical Methods. Thousands Oaks, CA: Sage, 2013.

Łastowski, Krzysztof. “On Multi-level Scientific Theories.” In: Idealization II: Forms and Application. Poznań Studies in the Philosophy of the Sciences and the Humanities, Vol. 17, eds. Jerzy Brzeziński, Francesco Coniglione, 
T.A.F. Kuipers, and Leszek Nowak. Amsterdam-Atlanta: Rodopi, 1990, pp. 33-59.

Łastowski, Krzysztof. Rozwój teorii ewolucji. Studium metodologiczne [The Development of the Theory of Evolution. A Methodological Study]. Poznań: Wyd. UAM, 1987.

Łastowski, Krzysztof. “The Theory of Development of Species and the Theory of Motion of Socio-Economic Formation." In: Social Classes Action and Historical Materialism. Poznan Studies in the Philosophy of the Sciences and the Humanities, Vol. 6, ed. Leszek Nowak. Amsterdam-Atlanta GA: Rodopi, 1978, pp. 122-157.

Lazari-Pawłowska, Iija. "Idiograficzna koncepcja historii” [The Idiographic Concept of History]. Studia Filozoficzne, No. 1, 1958, pp. 14-41.

Lorenz, Chris. “'The Times They Are a-Changin.' On Time, Space and Periodization in History." In: Handbook of Research in Historical Culture and Education, eds. Mario Carretero, Stephen Berger, and Maria Grever. London: Palgrave, 2017, pp. 109-130.

Lorenz, Chris. "You got your history, I got mine.' Some Reflections on Truth and Objectivity in History." Österreichische Zeitschrift für Geschichtswissenschaften, Vol. 4, 1999, pp. 563-584.

Löwith, Karl. Meaning in History. Chicago/London: University of Chicago Press, 1949.

Lyotard, Jean-François. The Postmodern Condition A Report on Knowledge. Manchester: Manchester University Press, 1984.

Malewski, Andrzej and Jerzy Topolski. Studia z metodologii historii [Studies in the Methodology of History]. Warszawa: PWN, 1960.

Malewski, Andrzej and Jerzy Topolski. "The Nomothetic versus the Idiographic Approach to History." In: Idealization XIII: Modeling in History. Poznań Studies in the Philosophy of the Sciences and the Humanities, Vol. 97, ed. Krzysztof Brzechczyn. Amsterdam/New York: Rodopi, [1960] 2009, pp. 299-310.

Mauro, Frédéric. "Towards an Intercontinental Model: European Overseas Expansion between 1500 and 1800." The Economic History Review, sec. ser., No. 1(14), 1961, pp. 1-17.

McCloskey, Donald N. "History, Differential Equations, and the Problem of Narration." History and Theory, Vol. 30, No. 1, 1991, pp. 21-36.

Moore, Barrington. Social Origins of Democracy and Dictatorship. Boston:

Beacon Press, 1966. 
Nowak, Leszek. "Byt i myśl. Przyczynek do metafizyki unitarnej" ["Being and Thought. Contribution to Unitary Metaphysics"). Studia Filozoficzne, No. 1, 1989, pp. 1-18.

Nowak, Leszek. Byt i myśl. U podstaw negatywistycznej metafizyki unitarnej; Vol. 1: Nicość $i$ istnienie [Being and Thought. At the Basis of Negativist Unitary Metaphysics; Vol. I: Nothingness and Existence]. Poznań: Zysk i S-ka, 1998.

Nowak, Leszek. "Efekt kresowy w procesie historycznym" [The BorderlandEffect in Historical Process]. In: Marksizm, liberalizm, próby wyjścia, eds. Leszek Nowak and Piotr Przybysz. Poznań: Zysk i S-ka, 1997, p. 307-319.

Nowak, Leszek. Model ekonomiczny. Studium z metodologii ekonomii politycznej. [The Economic Model. A Study in the Methodology of Political Economy]. Warszawa: PWE, 1972.

Nowak, Leszek. "On Postmodernist Philosophy: An Attempt to Identify Its Historical Sense." In: The Postmodernist Critique of the Project of Enlightenment. Poznań Studies in the Philosophy of the Sciences and the Humanities, Vol. 58, ed. Sven.-Eric Liedman. Amsterdam/Atlanta: Rodopi, 1997, pp. 123-134.

Nowak, Leszek. "On the (Idealizational) Structure of Economic Theories." Erkenntnis, No. 30, 1989, pp. 225-246.

Nowak, Leszek. "O zagadnieniu tak zwanej transformacji ustrojowej." In: Społeczna transformacja $w$ refleksji humanistycznej, ed. Krystyna Zamiara, Poznań: Wyd. UAM, 1994, pp. 117-129.

Nowak, Leszek. "O zasadzie abstrakcji i stopniowej konkretyzacji" [On the Principle of Abstraction and Gradual Concretization]. In: Założenia metodologiczne "Kapitału" Marksa, ed. Jerzy Topolski. Warszawa: KiW, 1970, pp. 123-218.

Nowak, Leszek. Power and Civil Society. Toward a Dynamic Theory of Real Socialism. New York: Greenwood Press, 1991.

Nowak, Leszek. Property and Power. Towards a Non-Marxian Historical Materialism. Dordrecht: Reidel, 1983.

Nowak, Leszek. "Remarks on the Christian Model of Man and the Nature of Interpretation." Social Theory and Practice. An International and Interdisciplinary Journal of Social Philosophy, No. 1(15), 1989, pp. 107-117.

Nowak, Leszek. "Teoria formacji społeczno-ekonomicznej jako teoria adaptacyjna" [The Theory of a Socio-Economic Formation as an Adaptive Theory]. In: Założenia materializmu historycznego, ed. Leszek Nowak. Warszawa/Poznań, PWN, 1978, pp. 59-76.

Nowak, Leszek. "The Idealizational Approach to Science: A Survey." In: Idealization III: Approximation and Truth. Poznan Studies in the 
Philosophy of the Science and the Humanities, Vol. 25, eds. Jerzy Brzeziński and Leszek Nowak. Amsterdam/Atlanta, GA: Rodopi, 1992, pp. 9-63.

Nowak, Leszek. "The Idealizational Methodology and Economics. Replies to Diederich, Hoover, Janssen, Jorland and Maki." In: Idealization VI: Idealization in Economics. Poznan Studies in the Philosophy of Sciences and the Humanities, Vol. 38, eds. Bert Hamminga and Neil De Marchi. Amsterdam-Atlanta, GA: Rodopi, 1994, pp. 303-336.

Nowak, Leszek. The Structure of Idealization. Towards a Systematic Interpretation of the Marxian Idea of Science. Dordrecht: Reidel, 1980.

Nowak, Leszek. "The Theory of Socio-economic Formations as a Theory of Adaptation Processes." In: Social Classes Action and Historical Materialism. Poznań Studies in the Philosophy of the Sciences and the Humanities, Vol. 6, ed. Leszek Nowak. Amsterdam-Atlanta GA: Rodopi, 1982, pp. 110-121.

Nowak, Leszek. "Thoughts Are Facts of Possible Worlds. Truths Are Facts of a Given World." Dialectica, Vol 45, No. 4, 1991, pp. 273-287.

Nowak, Leszek. U podstaw dialektyki marksowskiej. Próba interpretacji kategorialnej [Foundations of the Marxian Dialectic. An Attempt at a Categorial Interpretation]. Warszawa: PWN, 1977.

Nowak, Leszek. U podstaw Marksowskiej metodologii nauki [Foundations of the Marxian Methodology of Science]. Warszawa: PWN, 1971.

Nowak, Leszek. U podstaw teorii socjalizmu; Vol. 1: Własność i władza. O konieczności socjalizmu; Vol. 2: Droga do socjalizmu. O konieczności socjalizmu w Rosji; Vol. 3: Dynamika władzy. O strukturze i konieczności zaniku socjalizmu. [The Foundations of the Theory of Socialism; Vol. 1: Property and Power. On the Necessity of Socialism; Vol. 2: A Path to Socialism. On the Necessity of Socialism in Russia; Vol. 3: The Dynamics of Power. On the Structure and Necessity of the Decline of Socialism]. Poznań: Nakom, 1991.

Nowak, Leszek. Władza. Próba teorii idealizacyjnej [Power. An Attempt at an Idealizational Theory]. Warszawa: In Plus, 1988.

Nowak, Leszek. Wolność i władza. Przyczynek do nie-Marksowskiego materializmu historycznego [Freedom and Power. Contribution to nonMarxian Historical Materialism]. Poznań: NZS, 1981.

Nowak, Leszek. Wstęp do idealizacyjnej teorii nauki [An Introduction to the Idealizational Theory of Science]. Warszawa: PWN, 1977.

Nowak, Leszek. Wykłady z filozofii marksistowskiej; Vol. 2: Ontologia i epistemologia [Lectures in Marxist Philosophy; Vol. 2: Ontology and Epistemology]. Poznań: Wyd. UAM, 1978. 
Nowak, Leszek. Zasady marksistowskiej filozofii nauki. Próba systematycznej rekonstrukcji [The Principles of Marxist Philosophy of Science. An Attempt at a Systematic Reconstruction]. Warszawa: PWN, 1974.

Nowak, Leszek, ed. Dimensions of the Historical Process. Poznań Studies in the Philosophy of the Sciences and the Humanities, Vol. 13. Amsterdam-Atlanta, GA: Rodopi, 1989.

Nowak, Leszek. ed. Założenia materializmu historycznego [Assumptions of Historical Materialism]. Warszawa-Poznań: PWN, 1978.

Nowak, Leszek and Izabella Nowakowa. The Richness of Idealization. Poznań Studies in the Philosophy of the Sciences and the Humanities, Vol. 69. Amsterdam-New York: Rodopi, 2000.

Nowak, Leszek, Katarzyna Paprzycka, and Marcin Paprzycki. "On Multilinearity of Socialism." In: Social System, Rationality and Revolution. Poznań Studies in the Philosophy of the Sciences and the Humanities, Vol. 33, eds. Leszek Nowak and Marcin Paprzycki. Amsterdam: Rodopi, 1993, pp. 355-371.

Nowak, Leszek and Marcin Paprzycki. eds. Social System, Rationality and Revolution. Poznań Studies in the Philosophy of Science and the Humanities, Vol. 33. Amsterdam-Atlanta, GA., Rodopi, 1993.

Nowak, Leszek and Piotr Przybysz. eds. Marksizm, liberalizm, próby wyjścia [Marxism, Liberalism, Attempts of Exit]. Vol. 17. Poznań: Zysk i S-ka, 1997.

Nowakowa, Izabela. Z problematyki teorii prawdy w filozofii marksistowskiej [From the Problem of the Theory of Truth in the Marxist Philosophy]. Poznan: UAM, 1977.

Nowakowa, Izabela. Zmienność i stałość w nauce. Przyczynek do metodologii związków diachronicznych [Variability and Stability in Science. Contribution to Methodology of Diachronic Connections]. Poznań: Nakom, 1991.

Paprzycka, Katarzyna and Marcin Paprzycki. "Accuracy, Essentiality and Idealization." In: Idealization III. Approximation and Truth. Poznań Studies in the Philosophy of Sciences and the Humanities, Vol. 25, eds. Jerzy Brzeziński and Leszek Nowak. Amsterdam - Atlanta, GA: Rodopi, 1992, pp. 255-265.

Paprzycka, Katarzyna and Marcin Paprzycki. "A Note on the Unitarian Explication of Idealization." In: Idealization III: Approximation and Truth. Poznań Studies in the Philosophy of Sciences and the Humanities, Vol. 25, eds. Jerzy Brzeziński and Leszek Nowak. Amsterdam - Atlanta, GA: Rodopi, 1992, pp. 279-283.

Paprzycka, Katarzyna and Marcin Paprzycki. "How Do Enslaved People Make Revolutions?.” In: Social System, Rationality and Revolution. Poznań Studies 
in the Philosophy of the Sciences and the Humanities, Vol. 33, eds. Leszek Nowak and Marcin Paprzycki, Amsterdam: Rodopi, 1993, pp. 251-265.

Paprzycki Marcin. "The Non-Christian Model of Man. An Attempt at a Psychoanalitic Explanation." In: Social System, Rationality and Revolution. Poznań Studies in the Philosophy of the Sciences and the Humanities, Vol. 33, eds. Leszek Nowak and Marcin Paprzycki. Amsterdam: Rodopi, 1993, pp. 205-215.

Połatyński, Marcin. "O koalicji i rozłamie partyjnym. Przyczynek do teorii subspołeczeństwa partyjnego w nie-Marksowskim materializmie historycznym [On Coalition and a Division in a Party. A Contribution to the Theory of a Party Sub-society in non-Marxian Historical Materialism]. In: Jednostka w układzie społecznym. Próba teoretycznej konceptualizacji, eds. Krzysztof Brzechczyn, Mieszko Ciesielski, and Eliza Karczyńska. Poznań: Wyd. Naukowe WNS UAM, 2013, pp. 153-160.

Polkinghorne, John C. "Prawa przyrody i prawa fizyki" [The Laws of Nature and the Laws of Physics]. Znak, No. 5, 1993, pp. 59-69.

Pomorski, Jan. "On Historical Narration. A Contribution to the Methodology of a Research Programme." In: Narration and Explanation. Contribution to the Methodology of the Historical Research. Poznan Studies in the Philosophy of Science and the Humanities, Vol. 19, ed. Jerzy Topolski. Amsterdam Atlanta, GA: Rodopi, 1990, pp. 41-54.

Pomorski, Jan. Paradygmat "New Economic History." Studium z teorii rozwoju nauki historycznej [A Paradigm of "New Economic History." A Study in the Theory of the Development of the Historical Sciences.]. Lublin: Wyd. UMCS, 1985.

Pomorski, Jan. W poszukiwaniu modelu historii teoretycznej [Searching for a Model of Theoretical History]. Lublin: Wyd. UMCS, 1984.

Pomorski, Jan. "Wprowadzenie: spory wokół narracji historycznej [Introduction: A Dispute Concerning Historical Narrative]. In: Metodologiczne problemy narracji historycznej, ed. Jan Pomorski. Lublin: Wyd. UMCS, 1990, pp. 11-25.

Pomorski, Jan, ed. Metodologiczne problemy narracji historycznej [Methodological Problems of a Historical Narrative]. Lublin: Wyd. UMCS, 1990.

Popper, Karl Raimund. "Prediction and Prophesy in the Social Science." In: Karl Raimund Popper, Conjectures and Refutations: The Growth of Scientific Knowlegde. New York: Harper \& Row, [1948] 1968.

Popper, Karl Raimund. The Poverty of Historicism. New York: Harper \& Row, [1944/1945] 1964. 
Przybysz, Piotr. "Pochwała metody" [Apology of the Method]. Czas Kultury, Nos. 1-2, 1992, pp. 51-55.

Reisch, George. "Chaos, History and Narrative." History and Theory, Vol. 30, No. 1, 1991, pp. 1-20.

Reisch, George. "Scientism without Tears: A Reply to Roth and Ryckman." History and Theory, Vol. 34(1), 1995, pp. 45-57.

Rogacz, Dawid. Chińska filozofia historii. Od początków do końca XVIII wieku [Chinese Philosophy of History. From the Beginnings to the End of the Eigtheenth Century] Poznań: Wyd. Naukowe UAM, 2019.

Rostow Walt, The Stages of Economic Growth. A Non-Communist Manifesto. Cambridge: Cambridge University Press, 1964.

Roth, Paul A. and Thomas S. Ryckman. "Chaos, Clio and Scientific Illusions of Understanding." History and Theory, Vol. 34(1), 1995, pp. 30-40.

Rozov, Nikolai S. "An Apologia for Theoretical History," History and Theory, Vol. 37, 1997, pp. 336-352.

Schaff, Adam. Obiektywny charakter praw historii [The Objective Character of the Laws of History]. Warszawa: PWN, 1955.

Shermer, Michael. "Exorcising Laplace's Demon: Chaos and Anti-chaos, History and Metahistory." History and Theory, Vol. 34, No. 1, 1995, pp. 59-83.

Skocpol, Theda. "Analysing Causal Configuration in History: A Rejoinder to Nichols." Comparative Social Research, Vol. 9, 1986, pp. 187-194.

Skocpol, Theda. State and Social Revolutions. Cambridge: Cambridge University Press, 1979.

Skocpol, Theda and Margaret Somers. "The Uses of Comparative History in Macro-Social Inquiry." Comparative Studies in Society and History, Vol. 22, 1980, pp. 156-173.

Stewart, Ian. Does God Play Dice? The New Mathematics of Chaos. Malden/ Oxford: Wiley-Blackwell, 2002.

Szacki, Jerzy. Historia myśli socjologicznej [The History of Sociological Thought]. Warszawa: PWN, 2004.

Szwochert, Piotr. "Historical Narration in the Light of the Idealizational Theory of Science. A Recapitulation and Expansion." In: Idealization XIV: Models in Science. Poznań Studies in the Philosophy of Sciences and the Humanities, Vol. 108, eds. Giacomo Borbone and Krzysztof Brzechczyn. Leiden/Boston: Brill/Rodopi, 2016, pp. 299-318.

Tempczyk, Michał. "Chaos a harmonia świata" [Chaos and the Harmony of the World]. Znak, No. 5, 1993, pp. 50-59.

Tilly, Charles. As Sociology Meets History. New York: Academic Press, 1981. 
Tilly, Charles. Big Structures, Large Processes, Huge Comparisons. New York: Russell Sage Foundation, 1984.

Tilly, Charles, Coercion, Capital, and European States, AD 990-1990. Cambridge, MA, USA: B. Blackwell, 1990.

Tomczak, Grzegorz. "Is It Worth Winning a Revolution.” In: Social System, Rationality and Revolution. Poznan Studies in the Philosophy of the Sciences and the Humanities, Vol. 33, eds. Leszek Nowak and Marcin Paprzycki. Amsterdam - Atlanta, GA: Rodopi, 1993, pp. 265-276.

Tomczak, Grzegorz. "Struktura ruchów masowych. Przyczynek do problematyki rewolucji" [The Structure of Mass Movements. A Contribution to the Problem of Revolution]. In: Filozoficzne i metodologiczne podstawy teorii naukowych, eds. Jerzy Brzeziński and Krzysztof Łastowski. Poznań: PWN, 1989, pp. 253-263.

Tomczak, Grzegorz. “The Economic Collapse in Two Models of SocioEconomic Formation." In: Dimensions of the Historical Process. Poznań Studies in the Philosophy of the Science and the Humanities, Vol. 13, ed. Leszek Nowak. Amsterdam: Rodopi, 1989, pp. 259-269.

Topolski, Jerzy. Jak się pisze i rozumie historię. Tajemnice narracji historycznej [How to Write and Understand History. The Secrets of a Historical Narrative]. Warszawa: Rytm, 1996.

Topolski, Jerzy. Marksizm i historia [Marxism and History]. Warszawa: PWN, 1977.

Topolski, Jerzy. Narodziny kapitalizmu w Europie XIV-XVII wieku [The Birth of Capitalism in Europe in the 14th-17th Century]. Warszawa: PWN, 1987.

Topolski, Jerzy. Prawda i model w historiografii. [Truth and Model in Historiography]. Łódź: Wyd. Łódzkie, 1982.

Topolski, Jerzy. "Refleksje o systemie historiozoficznym nie-Marksowskiego materializmu historycznego" [Reflections on the historiosophical system of the non-Marxian Historical Materialism]. In: Ścieżki transformacji. Ujęcia teoretyczne i opisy empiryczne, ed. Krzysztof Brzechczyn. Poznań: Zysk i S-ka, 2003, pp. 279-294.

Topolski, Jerzy. "The Economic Model of the Wielkopolska Region in the 18th Century." In: Idealization XIII: Modeling in History. Poznan Studies in the Philosophy of the Sciences and the Humanities, Vol. 97, ed. Krzysztof Brzechczyn. Amsterdam/New York: Rodopi, [1977] 2009, pp. 269-285.

Topolski, Jerzy. "Verification in Economic History." Studia Historiae Oeconomicae, Vol. 21, 1994, pp. 19-27. 
Topolski, Jerzy. Wolność i przymus w tworzeniu historii [Freedom and Coercion in the Creation of History]. Warszawa: PWN, 1990.

Tucker, Aviezer, Our Knowledge of the Past: A Philosophy of Historiography. Cambridge: Cambridge University Press, 2004.

Wallerstein, Immanuel. The Essential Wallerstein. New York: The New Press, 2000.

Wallerstein, Immanuel. The Modern World-System II. Mercantilism and the Consolidation of the European World-Economy, 1600-1750. New York London: Academic Press, 1981.

Wallerstein, Immanuel. The Modern World-System III. The Second Era of Great Expansion of the Capitalist World-Economy, 1730-1840. New York - London: Academic Press, 1989.

Wallerstein, Immanuel. The Modern World-System. Capitalist Agriculture and the Origins of the European World - Economy in the 16th Century. New York: Academic Press, 1974.

Walsh, William Henry. An Introduction to Philosophy of History. New York: The Harvester Press, 1976.

Wichrowski, Marek. Spór o naturę procesu historycznego (od Hebrajczyków do śmierci Fryderyka Nietzschego) [The Dispute over the Nature of the Historical Process (from the Hebrews to the Death of Friedrich Nietzsche)]. Warszawa: Semper, 1995.

Witkowski, Michał. "On Adaptive and Functional Dependencies. An Attempt at a Categorial Approach." In: Dimensions of the Historical Process. Poznań Studies in the Philosophy of the Sciences and the Humanities, Vol. 13, ed. Leszek Nowak. Amsterdam-Atlanta, GA: Rodopi, 1989, pp. 147-56.

Witkowski, Michał. Z problematyki zmienności indywiduów. Przyczynek do ontologii kategorialnej [From the Problem of Volatility of Individuals. A Contribution to Categorial Ontology]. Poznań: Nakom, 1992.

Wittfogel, Karl A. Oriental Despotism. A Comparative Study of Total Power. Yale: University Press, 1972

Zagorin, Peter. "Prolegomena to the Comparative History of Revolution in Early Modern Europe." Comparative Studies in Society and History, No. 2, 1976, pp. 151-174.

Zarębski, Tomasz. "Struktura klasowa społeczeństw hydraulicznych. Próba parafrazy teorii Karla Augusta Wittfogla w aparaturze pojęciowej nieMarksowskiego materializmu historycznego" [A Class Structure of Hydraulic Societies. An Attempt at a Paraphrase of the Theory of Karl August Wittfogel in the Conceptual Apparatus of non-Marxian Historical Materialism]. In: Jednostka w układzie społecznym. Próba teoretycznej 
konceptualizacji, eds. Krzysztof Brzechczyn, Mieszko Ciesielski, and Eliza Karczyńska. Poznań: Wyd. Naukowe WNS UAM, 2013, pp. 207-222. Zielińska, Renata. Abstrakcja, idealizacja, generalizacja. Próba analizy metodologicznej [Abstraction, Idealisation, Generalisation. An Attempt at a Methodological Analysis]. Poznań: Wyd. UAM, 1981.

\section{Empirical and Historical Works}

Ajnenkiel, Andrzej. "The Evolution of the Forms of Government in Central Europe. 1918-1939." In: Dictatorships in East-Central Europe 1918-1939. Anthologies. Polish Historical Library, Vol. 4, ed. Janusz Żarnowski. Wrocław: Ossolineum, 1983, pp. 27-57.

Anderson, Perry. Passages from Antiquity to Feudalism. London: NLB, 1974. Arnold, Udo. Zakon Krzyżacki. Z Ziemi Świętej nad Bałtyk [The Teutonic Order: From the Holy Land to the Baltic]. Torun: Wyd. UMK, 1996.

Aubin, Herman. "The Lands East of the Elbe and German Colonization Eastwards." In: The Cambridge Economic History of Europe, Vol. I: From the Decline of the Roman Empire, eds. John Harold Clapham and Eileen Power. Cambridge: Cambridge University Press, 1942, pp. 361-398.

Babinskas, Nerijus. "Economic Challenges in Early Modern Ages and Different Responses of European Margins. Comparative Considerations Based on Historiography: The Cases of Polish-Lithuanian Commonwealth and Moldovian Principality." Romanian Journal for Baltic and Nordic Studies, Vol. 4, No. 2, 2012, pp. 51-62.

Babinskas, Nerijus. "Od feudalizmu do afrykańskiego sposobu produkcji. Problem typologii przednowoczesnych peryferyjnych społeczeństw europejskich" [From Feudalism to the African Mode of Production. The Problem of Typology of Pre-Modern Peripheral European Societies]. Człowiek i Społeczeństwo, Vol. 42, 2016, pp. 119-133.

Bak, Janos “The Late Medieval Period, 1382-1525.” In: History of Hungary, eds. Peter F. Sugar, Péter Hanák, and Tibor Frank. Indiana: Indiana University Press, 1990, pp. 50-72.

Barański, Marek. "Majątki możnowładcze na Węgrzech w XII w." [The Estates of Magnates in Hunagry in the 12th Century]. Przeglad Historyczny, Vol. 70, 1979, pp. 401-431.

Bartkowiak, Marian. Towarzystwo Jaszczurcze w latach 1397-1437 [The Lizard Union in 1397-1437]. Toruń: Towarzystwo Naukowe, 1948.

Barycz, Henryk and Jan Hulewicz, eds. Studia z dziejów kultury polskiej [Studies in the History of Polish Culture]. Warszawa: Gebethner \& Wolff, 1947. 
Bazylow, Ludwik. Historia Rosji [The History of Russia]. Wrocław: Ossolineum, 1985.

Betts, Reginald R. (ed.) Central and South East Europe, 1945-1948. London: Royal Institute of International Affairs, 1950.

Biskup, Marian, Zjednoczenie Pomorza Wschodniego z Polska w połowie XV wieku [The Unification of Eastern Pomerania with Poland in the Middle of the 15th Century]. Warszawa: PWN, 1959.

Biskup Marian and Gerard Labuda. Dzieje Zakonu Krzyżackiego w Prusach: gospodarka, społeczeństwo, państwo, ideologia [The History of the State of Teutonic Knights in Prussia: Economy, Society, State, Ideology]. Gdańsk: Wyd. Morskie, 1986.

Blum, Jeremy. "The Rise of Serfdom in Eastern Europe." American Historical Review," Vol. 62, No. 4, 1957, pp. 807-836.

Bogucka, Maria. "Miasta Europy środkowej w XIV-XVII w. Problemy rozwoju" [The Towns in Central Europe from the 14th to the 17th Century. Problems in Development]. Roczniki Dziejów Społecznych i Gospodarczych, Vol. 47, 1981, pp. 5-24.

Bogucka, Maria. "The Towns of East-Central Europe from the Fourteenth to the Seventeenth Century." In: Central Europe in Transition. From the Fourteenth to the Seventeenth Century, eds. Peter Burke, Antoni Mączak, and Henryk Samsonowicz. Cambridge: Cambridge University Press, 1985, pp. 97-107.

Bogucka, Maria and Henryk Samsonowicz. Dzieje miast i mieszczaństwa w Polsce przedrozbiorowej [The History of Towns and Burghers in Pre-Partition Poland]. Wrocław: Ossolineum, 1986.

Bojtár, Endre. "Eastern of Central Europe?" Cross Currents. A Yearbook of Central European Culture, No. 7, 1988, pp. 253-269.

Booth, Alan. "Food Riots in the North-West of England 1790-1801." Past and Present, Vol. 71, 1977, pp. 84-108.

Brenner, Robert. "Agrarian Class Structure and Economic Development in Preindustrial Europe." Past and Present, Vol. 70, 1976, pp. 30-75.

Brenner, Robert. "Economic Backwardness in Eastern Europe in Light of Developments in the West." In: The Origins of Backwardness in Eastern Europe. Economics and Politics from the Middle Ages until the Early Twentieth Century, ed. Daniel Chirot. Berkeley: University of California Press, 1985, pp. 15-51.

Brenner, Robert. “The Agrarian Roots of European Capitalism.” Past and Present, Vol. 97, 1982, pp. 16-111. 
Buczek, Karol. Książęca ludność stużebna w Polsce wczesnofeudalnej [Ducal Servant Classes in the Early-feudal Poland]. Wrocław: Ossolineum, 1958.

Burke, Peter. "Introduction: A Note on the Historiography of East-Central Europe." In: Central Europe in Transition. From the Fourteenth to the Seventeenth Century, eds. Peter Burke, Antoni Mączak, and Henryk. Samsonowicz. Cambridge: Cambridge University Press, 1985, pp. 1-2.

Burke, Peter, Antoni Mączak, and Henryk Samsonowicz, eds. East-Central Europe in Transition. From the Fourteenth to the Seventeenth Century. Cambridge: Cambridge University Press, 1985.

Chirot, Daniel. "The Growth of the Market and Service Labor Systems in Agriculture." The Journal of Social History, No. 2, 1975, pp. 67-80.

Chirot, Daniel, ed. The Origins of Backwardness in Eastern Europe. Economics and Politics from the Middle Ages until the Early Twentieth Century. Berkeley: University of California Press, 1985.

Cieślak, Edmund. Walki ustrojowe w Gdańsku i Toruniu oraz w niektórych miastach hanzeatyckich $w X V w$. [Systemic Struggles in Gdańsk and Torun and a Number of Towns of the Hanseatic League in the 15th Century]. Gdańsk: Gdańskie Towarzystwo Naukowe, 1960.

Cipolla, M. Carlo. Before the Industrial Revolution. European Society and Economy, 1000-1700. London: W. W. Norton and Co. 1976.

Cipolla, M. Carlo, ed. The Fontana Economic History of Europe. The Middle Ages. London-Glasgow: Collins, 1972.

Claphan, John Harald, Eileen Power, eds. The Cambridge Economic History of Europe, Vol. I: From the Decline of the Roman Empire. Cambridge: Cambridge University Press, 1942.

Delanty, Gerard. "The Historical Regions of Europe: Civilizational Backgrounds and Multiply Routes to Modernity." Historicka Sociologie, Nos. 1-2, 2012, pp. 9-24.

Demel, Juliusz. Historia Rumunii [The History of Romania]. Wrocław: Ossolineum, 1986.

Felczak, Waclaw. Historia Wegier [The History of Hungary]. Wrocław: Ossolineum, 1983.

Fügedi, Eric. “The Demographic Landscape of East-Central Europe.” In: Central Europe in Transition. From the Fourteenth to the Seventeenth Century, eds. Peter Burke, Antoni Mączak, and Henryk. Samsonowicz. Cambridge: Cambridge University Press, 1985, pp. 47-59.

Gąsiorowski, Andrzej. “Ze studiów nad szerzeniem się tzw. prawa niemieckiego we wsiach ziemi krakowskiej i sandomierskiej (do roku 1333)" [From the Studies on the Spread of the So-Called German Law in the Villages of 
Cracow and Sandomierz Lands (until 1333)] Roczniki Historyczne, Vol. 26, 1960, pp. 123-170.

Gierowski, Jerzy. Historia Polski 1505-1764 [The History of Poland 1505-1764]. Warszawa: PWN, 1983.

Gieysztor, Aleksander and Tadeusz Rosłanowski, eds. Miasta feudalne w Europie środkowo-wschodniej. Przemiany społeczne a układy przestrzenne [Feudal Towns in Central-East Europe]. Toruń: Polskie Towarzystwo Historyczne, 1974.

Górski, Karol. Państwo Krzyżackie w Prusach [The State of the Teutonic Knights in Prussia]. Gdańsk: Wydawnictwo Instytutu Bałtyckiego, 1946.

Górski, Karol. Zakon Krzyżacki a powstanie państwa pruskiego [The Teutonic Order and the Origins of Prussian State]. Wrocław: Ossolineum, 1977.

Grodecki, Roman. "Początki gospodarki folwarcznej w Polsce" [The Beginnings of a Manorial-Serf Economy in Poland.] In: Studia z dziejów kultury polskiej, eds. Henryk Barycz and Jan Hulewicz. Warszawa: Gebethner i Wolff, 1947, pp. 57-73.

Grzegorz, Maksymilian. Struktura administracyjna i własnościowa Pomorza Gdańskiego pod rzadami Zakonu Krzyżackiego w latach 1309-1454 [The Structure of Administration and Ownership of Gdan'sk Pomerania under the Rule of the Order of Teutonic Knights in 1309-1454]. Warszawa-PoznanToruń: PWN, 1987.

Halecki, Oskar. Historia Europy - jej granice i podzialy [The History of Europe - Borders and Divisions]. Lublin: Instytut Europy Środkowo-Wschodniej, 1994.

Hayashi, Tadayuki. "Masaryk's 'Zone of Small Nations' in His Discourse during World War I." In: Regions in Central and Eastern Europe: Past and Present, eds. Tadayuki Hayashi and Hiroshi Fukuda. Sapporo: The Slavic Research Center, 2007, pp. 3-20.

Heck, Roman and Marian Orzechowski. Historia Czechosłowacji [The History of Czechoslovakia]. Wrocław: Ossolineum, 1969.

Helleiner, Karl. "The Population of Europe from the Black Death to the Eve of the Vital Revolution." In: The Cambridge Economic History of Europe, Vol. 4: The Economy of Expanding Europe in the 16th and 17th Centuries, eds. E.E. Rich and Charles Wilson. Cambridge: Cambridge University Press, 1967, pp. 1-94.

Heller Mikhail and Aleksander Nekrich. Utopia in Power. The History of the Soviet Union from 1917 to the Present. Transl. Phyllis B. Carlos. New York: Summit Books, 1986. 
Hoszowski, Stanisław. "Dynamika rozwoju zaludnienia Polski w epoce feudalnej (X-XVIII w.)" [The Dynamics of the Evolution of Population Density of Poland in the Feudal Epoch (10th-13th Century)]. Roczniki Dziejów Społecznych i Gospodarczych, Vol. 13, 1951, pp. 136-199.

Hoszowski, Stanisław. "Rewolucja cen w środkowej Europie w XVI i XVII w." [The Price Revolution in Central Europe in the 16th and 17th century]. Kwartalnik Historyczny, Vol. 68, 1961, pp. 297-314.

Hroch, Miroslav and Josef Petran. "Europejska gospodarka i polityka XVI i XVII w.: kryzys czy regres." [The European Economy and Politics in the 16th and 17th century: Crisis or Regression.] Przeglad Historyczny, Vol 55, 1964, pp. 1-21.

Hunt, Verl F. "The Rise of Feudalism in Eastern Europe: A Critical Appraisal of the Wallertein 'Word - System' Thesis." Science and Society. An Independent Journal of Marxism, No. 1, 1978, pp. 43-62.

Husa, Václav. Historia Czechosłowacji [The History of Czechoslovakia]. Praga: Artia, 1967.

Kahan, Arcadius. "Notes on Serfdom in Western and Eastern Europe." The Journal of Economic History, Vol. 33, 1973, pp. 86-100.

Király, Bela. K. "Neo - Serfdom in Hungary." Slavic Review. American Quarterly of Soviet and East European Studies, No. 2, 1975, pp. 269-278.

Kirschbaum, Stanislav. Historical Reflections on Central Europe. New York: St. Martin Press, 1999.

Kiš, Danilo. "Variations on the Theme of Central Europe." Cross Currents. A Yearbook of Central European Culture, No. 6, 1987, pp. 1-14.

Kiss, Istvan N. "Agricultural and Livestock Production: Wine and Oxen. The Case of Hungary," In: Central Europe in Transition. From the Fourteenth to the Seventeenth Century, eds. Peter Burke, Antoni Mączak, and Henryk Samsonowicz. Cambridge: Cambridge University Press, 1985, pp. 84-97.

Klima, Anton. "Agrarian Class and Economic Development in Pre-industrial Bohemia." Past and Present, Vol. 85, 1979, pp. 49-68.

Koczy, Leon. Polityka baltycka Zakonu Krzyzackiego [The Baltic Policy of the State of Teutonic Knights]. Toruń: Wyd. Instytutu Bałtyckiego, 1936.

Koenigsberger, Helmut George and George L. Mosse. Europe in the Sixteenth Century. New York: Pearson, 1968.

Kofman, Jan. Nacjonalizm gospodarczy - szansa czy bariera rozwoju. Przypadek Europy Środkowo-Wschodniej w okresie międzywojennym [Economic Nationalism - a Chance or an Obstacle for Development. The Case of Central and Eastern Europe in the Interwar Period]. Warszawa: PWN, 1992. 
Komoroczy, Gyorgy. "Przegląd badań z zakresu węgierskiej historii gospodarczej opublikowanych w latach 1938-58" [A Review of the Research on the Hungarian Economic History Published between 1938 and 1958]. Roczniki Dziejów Społecznych i Gospodarczych, Vol. 22, 1960, pp. 167-190.

Konopczyński, Władysław. Dzieje Polski nowożytnej [The Modern History of Poland]. Warszawa: PAX, 1986.

Konrád, Geörgy. "Is the Dream of Central Europe Still Alive?." Cross Currents. A Yearbook of Central European Culture, No. 5, 1985, pp. 109-121.

Kormendy, Adrienne. "Kształtowanie się pojęcia 'prawa niemieckiego' (Ius Teutonicum) w Europie środkowo-wschodniej w XIII-XIV wieku” [The Formation of the Notion "German Law" (Ius Teutonicum) in CentralEastern Europe in the 13th and 14th century]. Przeglad Historyczny, Vol. 75, 1984, pp. 481-491.

Korta, Wacław. "Rozwój terytorialny wielkiej świeckiej własności feudalnej w Polsce do połowy XIII wieku" [Territorial Development of the Grand Secular Feudal Ownership in Poland until the Middle of the 13th Century"]. Sobótka. Śląski Kwartalnik Historyczny, Vol. 16, No. 4, 1961, pp. 528-566.

Kulesza, Władyslaw. Koncepcje ideowo-polityczne obozu rządzacego w Polsce w latach 1926-1935 [The Ideological/Political Concepts of the Ruling Camp in Poland in 1926-1935]. Wrocław: Ossolineum, 1985.

Kundera, Milan. "The Tragedy of Central Europe." The New York Review of Books, April 26, 1984, pp. 31-38.

Kurowski, Stefan. Ludność $w$ historii i w polityce polityce [Population in History and Politics]. Warszawa: Ośrodek Dokumentacji i Studiów Społecznych, 1980.

Łojek, Jerzy. Wokół sporów i polemik [Around Disputes and Polemics]. Lublin: Wydawnictwo Lubelskie, 1991.

Longworth, Philip. The Making of Eastern Europe. Londyn: The Macmilian Press, 1992.

Łowmiański, Henryk. Początki Polski, Vol. 3 [The Origins of Poland, Vol. 3]. Warszawa: PWN, 1967.

Łowmiański, Henryk. "Podstawy gospodarcze i społeczne powstania państwa polskiego i jego rozwoju do początku XII w.” [Economic and Social Foundations for the Emergence of Polish State and its Development until the Beginning of the 12th Century]. Kwartalnik Historyczny, Vol. 67, 1960, pp. 942-967.

Łowmiański, Henryk. Prusy - Litwa - Krzyżacy [Prussia - Lithuania - Teutonic Knights.] Warszawa: PWN, 1989. 
Łowmiański, Henryk. "Przemiany feudalne wsi polskiej do 1138 r." [Feudal Transformations of the Polish Village until 1138]. Przeglad Historyczny, Vol. 64, 1974, pp. 437-464.

Łukasiewicz, Sławomir. Trzecia Europa. Polska myśl federalistyczna w Stanach Zjednoczonych 1940-1971 [The Third Europe. Polish Federalist Thought in the United States 1940-1971]. Warszawa-Lublin: IPN, 2010.

Macek, Josef. "The Emergence of Serfdom in the Czech Lands." East-Central Europe, Vol. 9, Nos. 1-2, 1982, pp. 7-24.

Machura, Piotr. "Central-European Ethos: Equality, Social Emergence and Claims to Justice." In: Central-European Ethos or Local Traditions: Equality, Justice, eds. Jarmila Jurová, Milan Jozek, Andrzej Kiepas, and Piotr Machura. Brno: Albert, 2011, pp. 100-107.

Mączak, Antoni. "Jedyna i nieporównywalna? Kwestia odrębności Rzeczypospolitej w Europie XVI-XVII wieku” [Unique and Incomparable? The Issue of Distinctiveness of the Polish Republic in Europe in the 16th and 17th Century]. Kwartalnik Historyczny, Vol. 100, 1993, pp. 121-136.

Mączak, Antoni. Klientela. Nieformalne systemy władzy w Polsce i w Europie XVI-XVII w. [The Clientele. Informal Systems of Authority in Poland and in Europe of the 16th and 17th Century]. Warszawa: Semper, 1994.

Mączak, Antoni. U źródeł nowoczesnej gospodarki europejskiej [The Sources of Modern European Economy]. Warszawa: PWN, 1967.

Mączak, Antoni and Henryk Samsonowicz, " $Z$ zagadnień genezy rynku europejskiego: strefa bałtycka" [On the Issues of the Genesis of the European Market: The Baltic Zone]. Przeglad Historyczny, Vol. 55, 1964, pp. 198-222.

Mákkai, Laslo. Agrarian Landscapes of Historical Hungary in Feudal Times. Budapeszt: Akademia Kiadó, 1980.

Mákkai, Laslo. "Neo-Serfdom: Its Original Nature in East-Central Europe." Slavic Review. American Quarterly of Soviet and East European Studies, Vol. 2, 1975, pp. 225-239.

Małowist, Marian. Europa i jej ekspansja XIV-XVI w. [Europe and its Expansion in the 14th-16th Century]. Warszawa: PWN, 1993.

Małowist, Marian. "Polska a przewrót cen w Europie w XVI i XVII w." [Poland and the Price Revolution in Europe in the 16th and 17th Century]. Kwartalnik Historyczny, Vol. 68, 1961, pp. 315-320.

Małowist, Marian. Wschód a Zachód Europy w XIII-XVI w. Konfrontacja struktur spoleczno-gospodarczych [East and West of Europe in the 13th-16th Century. A Confrontation of Socio-Economic Structures]. Warszawa: PWN, 1973. 
Małowist, Marian. “Z problematyki dziejów gospodarczych strefy bałtyckiej we wczesnym średniowieczu" [From the Problems of Economic History of the Baltic Zone in the Early Middle Ages]. Roczniki Dziejów Społecznych i Gospodarczych, Vol. 10, 1948, pp. 81-120.

Małowist, Marian. “Z zagadnień popytu na produkty krajów nadbałtyckich w Europie zachodniej w XVI wieku." [On the Issues of Demand for Products from the Baltic Countries in Western Europe in the 16th Century]. Przeglad Historyczny, Vol. 50, 1959, pp. 720-752.

Masaryk, Tomáš. "Pangermanism and the Zone of Small Nations." New Europe, No. 1, 1916, pp. 271-277.

Mika, Alois. "Rozwój gospodarki dworskiej na ziemiach czeskich od XIV do XVII w." [The Development of a Manorial Economy in Bohemia from the 14th to the 17th Century]. Roczniki Dziejów Społecznych $i$ Gospodarczych, Vol. 22, 1960, pp. 11-30.

Modzelewski, Karol. Chłopi w monarchii wczesnopiastowskiej [The Peasantry in the Early-Piast Monarchy]. Wrocław: Ossolineum, 1987.

Modzelewski, Karol. Organizacja gospodarcza państwa piastowskiego (X-XI w.) [The Economic Organization of the Piast State (10th-11th Century)]. Wrocław: Ossolineum, 1975.

Naumann, Friedrich. Central Europe. Transl. Christabel Margaret Meredith. London: P.S. King \& Son, Limited, 1916.

Ochmański, Jerzy. Dzieje Rosji do roku 1861 [The History of Russia until 1861]. Warszawa: PWN, 1983.

Okey, Robin. "Central Europe/Eastern Europe: Behind Definitions," Past and Present, No. 137, 1992, pp. 102-133.

Pach, Zsigmond Pal. "The Development of Feudal Rent in Hungary in the Fifteenth Century.” The Economic History Review, 2nd ser., Vol. 19, No. 1, 1966, pp. 1-14.

Pach, Zsigmond Pal. The Role of East-Central Europe in International Trade (16th and 17th Centuries). Budapeszt: Akademia Kiadò, 1970.

Partsch, Joseph. Mitteleuropa. Die Lander und Volker von den Westalpen und dem Balkan bis an den Kanal und das Kurische Haff. Gotha: J. Perthes, 1904.

Pawelec, Tomasz. $Z$ drugiej strony Antlantyku. 'Młodsza Europa' w dawnych syntezach amerykańskich [On the other Side of Atlantic. The 'Younger Europe' in the Old American Historiographical Synthesis]. Cieszyn: PTH, 2013.

Piskorski, Jerzy. Kolonizacja wiejska Pomorza Zachodniego w XIII $i w$ początkach XIV wieku na tle procesów osadniczych w średniowiecznej Europie [Rural Colonization in Western Pomerania in the 13th and in the Beginnings 
of the 14th Century against the Background of Settlement Process in the Medieval Europe]. Poznań: PTPN, 1990.

Podraza, Antoni. "Europa Środkowa. Zakres przestrzenny i historia regionu" [Central Europe. Spatial Scope and the History of the Region]. Prace Komisji Środkowoeuropejskiej, Vol. 1, 1993, pp. 23-34.

Podwińska, Zofia. Technika uprawy roli w Polsce średniowiecznej [The Technique of Land Cultivation in Medieval Poland]. Wrocław-Warszawa-Kraków: Ossolineum, 1962.

Prodan, David. "The Origins of Serfdom in Transylvania." Slavic Review. American Quarterly of Soviet and East European Studies, Vol. 49, No. 1, 1990, pp. 1-18.

Reychman, Jerzy. Dzieje Węgier [The History of Hungary]. Łódź: PWN 1963.

Rosenberg, Hans. "The Rise of the Junkers in Brandenburg-Prussia, 14101653," Part I. American Historical Review, Vol. 49, No. 1, 1943, pp. 1-22.

Rusiński, Władysław. "Drogi rozwojowe folwarku pańszczyźnianego" [The Developmental Paths of a Villein Manor]. Przeglad Historyczny, Vol. 47, 1958, pp. 617-655.

Rusiński, Władysław. “Pustki' - problem agrarny feudalnej Europy” ['Fallow Land' - the Agrarian Problem of Feudal Europe]. Roczniki Dziejów Społecznych i Gospodarczych, Vol. 23, 1961, pp. 9-50.

Rusiński, Władysław. Rozwój gospodarczy ziem polskich w zarysie [The Outline of the Economic Development of Polish Land]. Warszawa: wydawnictwo, 1969.

Rusiński, Władysław. "Rugi chłopskie w Europie środkowo-wschodniej w XVIXVI1I w." [Evictions of the Peasantry in East-Central Europe from the 16th to the 18th Century]. Roczniki Dziejów Społecznych i Gospodarczych, Vol 38, 1977, pp. 1-47.

Russel, Josiah Cox. "Population in Europe 500-1500." In: The Fontana Economic History of Europe. The Middle Ages, ed. Carlo M. Cipolla. London-Glasgow: Collins, 1972, pp. 27-70.

Russocki, Stanisław. "Początki zgromadzeń stanowych w Europie środkowej" [The Beginnings of State Assemblies in Central Europe]. Przeglad Historyczny, Vol. 66, No. 2, 1975, pp. 171-188.

Russocki, Stanisław. "Spory o istotę i genezę feudalizmu europejskiego" [The Disputes over the Essence and Genesis of European Feudalism]. Kwartalnik Historyczny, Vol. 78, 1971, pp. 404-412.

Russocki, Stanisław. "Monarchie stanowe środkowo-wschodniej Europy XV-XV1 w." [Estate Monarchies in East-Central Europe in the 15th and 16th Century]. Kwartalnik Historyczny, Vol. 84, No. 1, 1977, pp. 73-93. 
Rutkowska-Płachcińska, Anna. "Dżuma w Europie Zachodniej w XIV w. straty demograficzne i skutki psychiczne" [The Plague in Western Europe in the 14th Century: Demographic Losses and Mental Consequences]. Przeglad Historyczny, Vol. 69, 1978, pp. 75-105.

Rutkowski, Jan. Historia gospodarcza Polski (do 1864 r.) [The Economic History of Poland (until 1864)]. Warszawa: PWN, 1953.

Rutkowski, Jan. Studia $z$ dziejów wsi polskiej w XVI-XVIII w. [The Studies in the History of the Polish Village in 16th-18th Century]. Warszawa: PWN, 1956.

Rutkowski, Jan. Wieś europejska późnego feudalizmu [The European Village in Late Feudalism]. Warszawa: PWN, 1986.

Ryszka, Franciszek. "European Fascism. Divergences and Similarities. Prospects of Comparative Research." In: Analogies and Differences. Dictatorships in East-Central Europe 1918-1939. Anthologies. Polish Historical Library, Vol. 4, ed. Janusz Żarnowski. Wrocław: Ossolineum, 1983, pp. 223-247.

Sadova, Vera. "Eksport czeskiego zboża do Niemiec a rozwój produkcji towarowej w Czechach okresie przedbiałogórskim" [Export of Bohemian Grain to Germany and the Development of Commodity Production in Bohemia in the Pre-Bílé Hoře Period]. Roczniki Dziejów Społecznych i Gospodarczych, Vol. 22, 1960, pp. 31-52.

Samsonowicz, Henryk. "Europa jagiellońska - czy jednością gospodarczą" [Jagiellonian Europe - an Economic Unity?]. Kwartalnik Historyczny, Vol. 84, 1977, pp. 93-100.

Samsonowicz, Henryk. Historia Polski do 1795 [The History of Poland until 1795]. Warszawa: Wydawnictwo Szkolne i Pedagogiczne, 1985.

Samsonowicz, Henryk. Życie miasta średniowiecznego średniowiecznego [The Life of a Medieval Town]. Warszawa: PWN, 1970.

Samsonowicz, Henryk and Antoni Mączak. "Feudalism and Capitalism: a Balance of Changes in East - Central Europe." In: Central Europe in Transition. From the Fourteenth to the Seventeenth Century, eds. Peter Burke, Antoni Mączak, and Henryk. Samsonowicz. Cambridge: Cambridge University Press, 1985, pp. 6-24.

Schöpflin, George. “The Political Traditions of Eastern Europe.” In: Eastern Europe. . . Central Europe. . Europe, ed. Stephen R. Graubard. San Francisco/Oxford: Boulder/Westview Press, 1991, pp. 59-94.

Sedlar, Jean W. "Introduction." In: East Central Europe in the Middle Ages, 1000-1500, ed. Jean W. Sedlar. Seatle/London: University of Washington Press, 1994, pp. ix-xi. 
Sinnhuber, Karl. "Central Europe, Mitteleuropa, L'Europe Centrale: An Analysis of a Geographical Term." Transactions and Papers, Vol. 20, 1954, pp. 15-39.

Soto, de Hernando. Inny szlak. Niewidzialna rewolucja $w$ Trzecim Świecie [Another Path. Third World's Invisible Revolution]. Transl. Stefan Makowiecki, Marian Wiśniewski, Dariusz Filar. Warszawa: Polskie Towarzystwo Współpracy z Klubem Rzymskim, 1991.

Schöffer, I. "The Second Serfdom in Eastern Europe as a Problem of Historical Explanation." Australian Historical Studies, Vol. 9, No. 3, 1959, pp. 46-61.

Špiesz, Anton. "Czechoslovakia's Place in the Agrarian Development of Middle and East Europe of Modern Times." Studia Historica Slovaca, Vol. 6, 1969, pp. 7-62.

Stańczyk, Jerzy. "Europa Środkowa - kryteria wyodrębniania i cechy regionu" [Central Europe - Criteria for Distinguishing and Characteristics of the Region]. Studia Polityczne, No. 12, 2001, pp. 197-211.

Sugar, Peter F. and Donald W. Treadgold, "Foreword." In: East Central Europe in the Middle Ages, 1000-1500, ed. Jean W. Sedlar. Seatle/London: University of Washington Press, 1994, pp. vi-viii.

Szekely, J. "Ideologia wojny chłopskiej na Węgrzech w 1514 r." [The Ideology of Peasant War in Hungary in 1514]. Kwartalnik Historyczny, Vol. 67, No. 3, 1960, pp. 634-649.

Szporluk, Roman. "Defining 'Central Europe': Power, Politics and Culture." Cross Currents. A Yearbook of Central European Culture, No 1, 1982, pp. 30-38.

Szücs, Jeno. “The Three Historical Regions of Europe: An Outline." Acta Historica Academiae Scientiarum Hungaricae, Vol. 29, No. 2/4, 1983, pp. 131-184.

Thomson, Harrison. Czechoslovakia in European History. Princeton: Princeton University Press, 1944.

Todorova, Maria. Imagining the Balkans. Oxford: Oxford University Press, 1997.

Tomaszewski, Jerzy. "Europa Środkowa i Południowo-Wschodnia: cechy charakterystyczne i granice regionu" [Central and South-East Europe: Characteristic Features and Region Borders]. Ekonomia, No. 16, 1976, pp. 129-139.

Tomaszewski, Jerzy. "The Economy of Central and South-Eastern European Countries during the Inter-War Years." In: Dictatorships in East-Central Europe 1918-1939. Anthologies, ed. Janusz Żarnowski. Wrocław:

Ossolineum, 1983, pp. 57-83. 
Topolski, Jerzy, "Causes of Dualism in the Economic Development of Modem Europe (A Tentative New Theory)". Studia Historiae Oeconomicae, No. 3, 1968, pp. 3-12.

Topolski, Jerzy. Jan Rutkowski (1886-1949). O nowy model historii [Jan Rutkowski (1886-1949). A New Model of History]. Warszawa: PWN, 1986.

Topolski, Jerzy. Polska w czasach nowożytnych Od środkowoeuropejskiej potęgi do utraty niepodległości (1501-1795) [Poland in Modern Times. From a Central-European Power to the Loss of Independence (1501-1795)]. Poznań: Wyd. UAM, 1994.

Topolski, Jerzy. Przełom gospodarczy w Polsce XVI wieku i jego następstwa [Economic Turn in Poland of the 16th Century and its Consequences]. Poznań: Wydawnictwo Poznańskie, 1998.

Topolski, Jerzy. "The Development and the Crisis of the Manorial System Based on Serf Labor: A Tentative Explanation." In: Entrepreneurship and the Transformation of the Economy (10th-20th Centuries). Essays in Honour of Herman Von der Wee, eds. Paul Klep, Eddy van Cauwenberghe, Herman Van der Wee and Lucie Verachten. Leuven: Leuven University Press, 1994, pp. 135-147.

Topolski, Jerzy. "The Manorial-Serf Economy in Central and Eastern Europe in the 16th and 17th Centuries." Agricultural History, Vol. 3, No, 48, 1974, pp. 341-352.

Tymieniecki, Kazimierz. "Prawo niemieckie w rozwoju społecznym wsi polskiej" [The Role of German Law in the Social Development of Polish Village]. Kwartalnik Historyczny, Vol. 33, 1923, pp. 38-79.

Tymieniecki, Kazimierz. "W sprawie zaostrzonego poddaństwa w Polsce i Europie Środkowej" [On the Issue of Exacerbated Serfdom in Poland and Central Europe]. Roczniki Historyczne, Vol. 24, 1958, pp. 283-328.

Walters, Garrison E. The Other Europe. Eastern Europe to 1945. Syracuse: Syracuse University Press, 1989.

Wandycz, Piotr. The Price of Freedom: A History of East Central Europe from the Middle Ages to the Present. London - New York: Routledge, 2001.

Wędzki, Andrzej. Początki reformy miejskiej w środkowej Europie do pot. XIII wieku (Słowiańszczyzna Zachodnia) [The Beginnings of the Urban Reform in Central Europe until the Middle of the 13th Century (Western Slavs)]. Warszawa: PWN, 1974.

White, Lynn. Medieval Technology and Social Change. Oxford: Oxford University Press, 1962.

Wojtanowicz, Józef. "Europa Środkowa jako region fizycznogeograficzny podstawy wydzielenia, granice" [Central Europe as a Physical-Geographical 
Region - the Basis for Distinguishing, Borders]. Przeglad Geograficzny, Vol. 52, No. 3, 1999, pp. 211-223.

Wójcik, Zbigniew. Historia powszechna XVI-XVII w [World History of the 16th-17th Century]. Warszawa: PWN, 1979.

Wright, William E. "Neo-Serfdom in Bohemia." Slavic Review. American

Quarterly of Soviet and East European Studies, No. 2, 1975, pp. 239-253.

Wyczański, Andrzej. "Czy chłopu było źle w Polsce XVI wieku?” [Were

Peasants Unhappy in Poland of the 16th Century?]. Kwartalnik Historyczny, Vol. 85, 1978, pp. 626-641.

Wyczański, Andrzej. Studia nad folwarkiem szlacheckim $w$ Polsce $w$ latach 1500-1580 [Studies on the Nobility Farm in Poland in the Years 1500-1580]. Warszawa: PWN, 1960.

Wyczański, Andrzej. “The System of Power in Poland, 1370-1648.” In: Central Europe in Transition. From the Fourteenth to the Seventeenth Century, eds. Peter Burke, Antoni Mączak, and Henryk. Samsonowicz. Cambridge: Cambridge University Press, 1985, pp. 140-153.

Wyczański, Andrzej. Wieś polskiego Odrodzenia [The Village in the Polish Renaissance]. Warszawa: PWN, 1969.

Zajączkowski, Stanisław. Podbój Prus i ich kolonizacja przez Krzyżaków [The Conquest and Colonization of Prussia by the Teutonic Knights]. Torun: Wydawnictwo Instytutu Bałtyckiego, 1935.

Zientara, Benedykt. "Drang nach Osten (Parcie na Wschód)" [Drang nach Osten (March on the East)]. Mówiq Wieki, No. 4, 1984, pp. 1-2.

Zientara, Benedykt. "Przemiany społeczno-gospodarcze i przestrzenne miast w dobie lokacji" [Socio-economic and Spatial Transformations of Towns in the Period of Location]. In: Miasta feudalne w Europie środkowo-wschodniej. Przemiany społeczne a układy przestrzenne, eds. Andrzej Gieysztor and Tadeusz Rosłanowski. Toruń: Polskie Towarzystwo Historyczne, 1974, pp. 8-9.

Zientara, Benedykt. "Walonowie na Śląsku w XII i XIII w." [Walloons in Silesia in the 12th and 13th Century]. Przeglad Historyczny, Vol. 66, 1975, pp. 349-368.

Zientara, Benedykt. “Z zagadnień spornych tzw. 'wtórnego poddaństwa' w Europie środkowej" [From the Disputed Issues of the So-called 'Second Serfdom' in Central Europe]. Przeglad Historyczny, Vol. 1, No. 47, 1956, pp. 3-47.

Zientara, Benedykt. “Źródła i geneza 'prawa niemieckiego' (ius Teutonicum) na tle ruchu osadniczego w Europie zachodniej i środkowej w XI- XII w." [The Source and Genesis of the 'German Law' (ius Teutonicum) against 
the Settlement Movement in Western and Central Europe in the 11th-12th Century]. Przeglad Historyczny, Vol. 69, 1978, pp. 47-74.

Zimányi, Vera. Economy and Society in Sixteenth and Seventeenth Century Hungary (1526-1650). Budapeszt: Akademia Kiadó, 1987.

Żarnowski, Janusz. "Authoritarian Systems in Central and South-Eastern Europe (1918-1939).” In: Analogies and Differences. Dictatorships in EastCentral Europe 1918-1939. Anthologies. Polish Historical Library, Vol. 4, ed. Janusz Żarnowski. Wrocław: Ossolineum, 1983, pp. 9-27.

Żarnowski, Janusz. "W sprawie genezy systemu państw narodowych w Europie Środkowej i Południowo-Wschodniej po 1918 roku" [The Issue of the Genesis of the System of National States in Central and South-East Europe after 1918]. Kwartalnik Historyczny, Vol. 3, 1970, pp. 585-604.

Żytkowicz, Leonid. "Przesłanki i rozwój przytwierdzenia do gleby ludności wiejskiej w Polsce - poł. XIV w. - początek XVI w." [The Reasons for and the Development of the Binding of the Rural Population to Land in Poland from the Middle of the 14th Century to the Early 16th Century]. Przeglad Historyczny, Vol. 75, 1984, pp. 3-22.

Żytkowicz, Leonid. "Trends of Agrarian Economy in Poland, Bohemia and Hungary from the Middle of the Fifteenth to the Middle of the Seventeenth Century." In: Central Europe in Transition. From the Fourteenth to the Seventeenth Century, eds. Peter Burke, Antoni Mączak, and Henryk. Samsonowicz. Cambridge: Cambridge University Press, 1985, pp. 59-84. 



\section{Name Index}

A

Abramowski, Edward 345

Ackoff, Russel L. 154, 353

Ajnenkiel, Andrzej 320, 368

Alaric I 38

Albrecht, Duke of Brunswick 191

Albrecht, Landgrave of

Thuringia 191

Anderson, Perry 259, 368

Andrew II, king of Hungary 302

Andropov, Yuri 197

Arnold, Udo 188, 368

Atkinson, Ronald Field 19, 353

Aubin, Herman 274, 368

Augustine of Hippo 34, 38, 39, 353

B

Babinskas, Nerijus 64, 263, 368

Bak, Janos 305, 368

Banaszak, Tomasz 176, 353

Barański, Marek 260, 368

Bartkowiak, Marian 193, 368

Barycz, Hernyk 294, 368, 371

Bazylow, Ludwik 199, 200, 369

Benton, Ted 30, 353

Berger, Stephen 360

Berlin, Isaiah 6, 20, 21, 27, 36, 353

Betts, Reginald R. 53, 369

Biskup, Marian 185, 186-191, 193, 369

Blum, Jeremy $7,55,57,79,80-82$, $84,85,369$

Bogucka, Maria 278, 281, 283, 290-292, 298, 301, 308, 369

Bojtár, Endre 44, 369

Bolotnikov, Ivan 199

Bonnell, Victoria E. 107, 108, 353

Booth, Alan 229, 230, 369
Borbone, Giacomo 10, 94, 109, 158, 353, 355, 365

Bratkiewicz, Jarosław 24, 353

Brenner, Robert 7, 57, 65-69, 86, 369

Brzechczyn, Krzysztof 10, 32, 109, $114,128,142,158,163,171,172$, 174-176, 181, 190, 197, 320, 321, $334,339,341,353-358,360,364$, $365,366,368$

Brzeziński, Jerzy 94, 102, 104, 113, $147,155,171,231,324,356,358$, $359,362,363,366$

Buczek, Karol 262, 370

Buksiński, Tadeusz 20, 34, 35, 356

Burbelka, Jolanta 324, 356

Burke, Peter 44, 49, 53, 270, 271, 290, 296, 301, 306, 369, 370, 372, $377,380,381$

C

Carlos, Phyllis 371

Carretero, Mario 360

Casimir Jagiellonian, king of Poland 288

Casimir the Great, king of Poland 293

Charlemagne 51, 196

Chirot, Daniel 7, 57, 65, 75-77, 369, 370

Christabel, Margaret Meredith 375

Chwalisz, Piotr 105, 356

Ciesielski, Mieszko 114, 171, 172, 174-176, 224, 339, 354, 356, 357, 364,368

Cieślak, Edmund 191, 370

Cipolla, M. Carlo 270, 370, 376

Clapham, John Harald 274, 368 
Cohn, Norman 35, 357

Collins, Randall 32, 33, 357

Comte Auguste 34

Coniglione, Francesco 94, 102, 104, 357-359

Craib, Ian 30, 353

Czajkowski, Waldemar 171, 357

D

Danto, Arthur 19, 357

De Marchi, Neil 155, 358, 362

Delanty, Gerard 42, 370

Demel, Juliusz 304, 370

Domańska, Ewa 34, 357

Domar, Evsey D. 7, 115,

117-120, 357

Dózsa 304, 305

E

Egiert, Robert 224, 357

F

False Dmitry I 199

False Dmitry II 199

Felczak, Walczak 304, 370

Ferdinand I 309, 310

Filar, Dariusz 378

Frank, Tibor 305, 368

Fügedi, Eric 271, 370

Fukuda, Hiroshi 52, 371

Fukuyama, Francis 33, 34, 37, 39,357

Fuliński, Andrzej 136, 137, 357

G

Gadamer, Hans George 143, 144, 153,358

Garcia de la Sienra, Adolfo 224, 358

Garner, Lawrence 359

Gawor, Leszek 34, 358

Gąsiorowski, Andrzej 271, 370

Gellner, Ernest 33, 358
Genghis Khan 198

George of Poděbrady, king of Bohemia 309

Ghosh, Kenneth 22, 358

Gierowski, Jerzy 200, 371

Gieysztor, Andrzej 279, 371, 380

Goćkowski, Janusz 9

Górski, Karol 188, 195, 371

Grabińska, Teresa 9, 321, 354

Grabski, Andrzej Feliks 19, 358

Graubard, Stephen R. 46, 377

Grever, Maria 360

Grodecki, Roman 294, 296, 371

Grzegorz, Maksymilan 192, 371

Gupta, Shiv K. 154, 353

Gutenberg, Johannes 150

H

Halecki, Oskar 44, 48, 371

Hall, John A. 30, 358

Hamminga, Bert 155, 358, 362

Hanák, Peter 305, 368

Handelsman, Marceli 139, 142, 143,358

Hardy, Henry 21, 353

Hayashi, Tadayuki 52, 371

Heck, Roman 310-312, 314, 371

Hegel, George Wilhelm Friedrich 33, 34

Helleiner, Karl 271, 371

Heller, Mikhail 197, 198, 201, 371

Herodotus 24

Holton, Robert 281, 358

Hornowska, Elżbieta 102, 103, 358

Hoszowski, Stanisław 280, 372

Hroch, Miroslav 280, 372

Hulewicz, Jan 294, 368, 371

Hunt, Verl F. 64, 85, 372

Huntington, Samuel 25-27, 39, 359

Husa, Vaclav 310, 312, 314, 372 


\section{I}

Iyer, Arun 358

Ivan the Terrible 197

J

Jozek, Milan 51, 374

Jurová, Jarmila 51, 374

K

Kahan, Arcadius 283, 372

Kalberg, Stephen 107, 359

Kamenev, Lev 201

Kant Immanuel 34

Karczyńska, Eliza 114, 171, 172, 174-176, 339, 354, 356, 357, 364, 368

Kieniewicz, Jan 337, 338, 359

Kiepas, Andrzej 51, 374

Király, Bela K. 305, 372

Kirschbaum, Stanislav 53, 372

Kiš, Danilo 44, 372

Kiss, Istvan N. 306, 372

Klarman, Agnieszka 176, 355

Klawiter, Andrzej 105, 140, 171, 207, 324, 356, 359

Klein, Lawrence 91, 92, 359

Klima, Anton 312, 313, 372

Kluchevsky, Vasily 119

Kłosek, Eugeniusz 176, 355

Kochanowicz, Jacek 128, 359

Koczy, Leon 184, 372

Koenigsberger, Helmut

George 280, 372

Kofman, Jan 52, 372

Komoroczy, Gyorgy 305, 373

Konopczyński, Władysław 298, 373

Konrad of Mazovia 190

Konrád, Georgy 44, 373

Kormendy, Adrienne 271, 373

Korta, Wacław 263, 373

Kuderowicz, Zbigniew 19, 20, 359

Kuipers, T.A.F. 102, 104, 358, 360
Kula, Witold 7, 120-129, 131, 359

Kulesza, Władysław 320, 373

Kundera, Milan 43, 373

Kurowski, Stefan 275, 373

L

Labuda, Gerard 185-191, 193, 369

Lamentowicz, Wojciech 224, 359

Lange, Matthew 107, 359

Lazari-Pawłowska, Iija 162, 360

Lenin, Vladimir 201-203

Longworth, Philip 268, 284, 286, 373

Lorenz, Chris 30, 31, 360

Louis I, king of Hungary 302

Louis II of Hungary 309

Lousse, E. 283

Lyotard, Jean-Francois 6, 20, 31, 32, $38,39,360$

$\mathbf{E}$

Łastowski, Krzysztof 20, 104, 171, 207, 213, 231, 324, 356, 359, 360,366

Łojek, Jerzy 139, 140, 373

Łowmiański, Henryk 185, 190, 191, $264,266,273,373,374$

Łukasiewicz, Sławomir 43, 374

M

Macek, Josef 308, 310, 374

Machura, Piotr 51, 374

Magala, Sławomir 324, 356

Mákkai, Laslo 305, 316, 374

Makowiecki, Stefan 378

Malewski, Andrzej 32, 163, 164, 360

Małowist, Marian 7, 57-59, 86, $87,270,271,274,275,280,298$, 374,375

Marcellinus 38 
Marx Karl 27, 33, 34, 115

Masaryk, Tomas 52, 375

Mauro, Frederic 7, 116, 131-135, 360

Mazur, Marcin 176, 365

Mączak, Antoni 49, 270, 271, 280 , 290, 291, 296, 301, 306, 369, 370, $372,374,377,380,381$

McCloskey, Donald N. 137, 360

Mieszko I 163

Mika, Alois 308, 310, 375

Modzelewski, Karol 260-266, 375

Moore, Barrington 33, 360

Mosse, George L. 280, 372

$\mathbf{N}$

Naumann, Friedrich 43, 375

Nekrich, Aleksander 197, 198, 201, 371

Nowak, Leszek 9, 10, 21, 27, 29, 30-32, 37, 91, 94, 98, 102, 104-106, $121,136,141,144,147,155,159$, $160,165,171,173,176,178,181$, 183, 184, 190, 198, 199, 201, 206-208, 210, 211, 213, 214, 219-226, 259, 324, 329-332, 338-343, 344, 353, 354-364, 366,367

Nowak, Marek 114, 354

Nowakowa, Izabella 94, 98, 157, 158,363

O

Ochmański, Jerzy 200, 375

Okey, Robin 44, 375

Orzechowski, Marian 310-312, 314,371

Otto I, German emperor 196

Otto II , German emperor 196

Otto III, German emperor 196

Otto III, Margrave of Brandenburg 191
Ottokar II, the king of Czech 191

Ottokar II 191

\section{$\mathbf{P}$}

Pach, Zsigmond Pal 280, 304-306, 375

Paprzycka Katarzyna 27, 94, 147, 224, 342, 343, 363

Paprzycki, Marcin 10, 27, 94, 147, 171, 176, 181, 190, 224, 341-343, 354, 355, 357, 363, 364, 366

Patryas, Włodzimierz 207, 324, 356, 359

Pawelec, Tomasz 43, 375

Petran, Josef 280, 372

Piskorski, Jerzy 272-274, 278, 375

Plato 35

Podraza, Antoni 44, 51, 54, 376

Podwińska, Zofia 273, 376

Polybius 35

Power, Eileen 274, 368, 370

Prodan, David 304, 376

Przybysz, Piotr 171, 176, 329, 330, $353,361,363,365$

$\mathbf{R}$

Reychman, Jerzy 304, 376

Rich, E.E 271, 371

Rickert, Heinrich 162

Rosenberg, Hans 196, 376

Rosłanowski, Tadeusz 279, 371, 380

Rusiński, Władysław 7, 57, 77-79, 85, 294, 299, 376

Russel, Josiah Cox 270, 376

Russocki, Stanisław 259, 271, 302, 376

Rutkowska-Płachcińska, Anna 270, 377

Rutkowski, Jan 7, 57, 82-84, 130, 294, 298, 377

Ryszka, Franciszek 320, 377 
S

Sadova, Vera 310, 377

Samsonowicz Henryk 49, 149, 150, $270,271,278,279,280,281$, 290-292, 296, 298, 301, 306, 369, $370,372,374,377,380,381$

Sayer Minas, J. 154, 353

Schöffer, I. 84, 85, 378

Schöpflin, George 44, 46-48, 377

Sedlar, Jean W. 53, 377, 378

Sigismund III Vasa 199, 200

Sinnhuber, Karl 44, 378

Skuratov, Malyuta 197

Soto, de Hernando 344, 345,378

Špiesz, Anton 310, 316, 378

Stalin, Joseph 22, 197, 198, 201

Stańczyk, Jerzy 52, 378

Sugar, Peter F. 53, 305, 368, 378

Swietopelk I, Duke of

Pomerania 197

Syrnyk, Jarosław 176, 355

Szekely, J. 304, 378

Szporluk, Roman 52, 378

Szücs, Jeno 44, 49, 50, 378

$\mathbf{T}$

Tempczyk, Michał 136, 365

Theodoric, Margrave of

Meisen 191

Thomson, Harrison 310, 378

Todorova, Maria 53, 378

Tomaszewski, Jerzy 52-54, 320, 378

Tomczak, Grzegorz 181, 231, 330, 331,366

Topolski, Jerzy 7, 9, 32, 41, 57, 64, 69-74, 82, 94, 115, 128-131, 138, $139,140,157,163,164,171,360$, $361,366,367,379$

Toynbee, Arnold 33, 38

Treadgold, Donald W. 53, 378
Tucker, Aviezer 6, 20, 33, 34, 36, 367

Tymieniecki, Kazimierz 75, 272, 277, 379

V

Vandevelde, Pol 358

Vasili IV, tsar of Russia 199, 200

Vico, Giambattista 19, 33

Vladislav IV, king of Poland 199, 200

Voltaire 19

W

Wallerstein, Immanuel 7, 33, 57, 60-64, 367

Walsh, William Henry 19, 367

Walters, Garrison E. 44, 45, 379

Wandycz, Piotr 44, 50, 53, 379

Weber, Max 115

Wędzki, Andrzej 278, 279, 379

White, Lynn 281, 379

Wichrowski, Marek 22, 34, 35,367

Wilson, Charles 271, 371

Wiśniewski, Marian 378

Witkowski, Michał 106, 207, 367

Wittfogel, Karl A. 24, 25, 379

Wojtanowicz, Józef 44, 45, 380

Wójcik, Zbigniew 54, 200, 380

Wright, William E. 311, 380

Wyczański, Andrzej 64, 290, 294-296, 298, 299, 380

Z

Zabierowski, Mirosław 321, 354

Zagorin, Peter 230, 231, 367

Zajączkowski, Stanisław 185, 195, 380

Zarathustra 35

Zarębski, Tomasz 174, 367

Zeidler, Paweł 20, 356

Zielińska, Renata 105, 368 
Zientara, Benedykt 7, 57, 74, 75, 85, Żółkiewski, Stanislav 199 $196,272,279,380,381$

Zimányi, Vera 301, 305, 381

Żytkowicz, Leonid 293, 294, 296, 381

$\dot{\mathbf{Z}}$

Żarnowski, Janusz 50, 320, 368, 377, 378,381 


\section{Subject Index}

A

adaptive mechanism 205-208

aggressiveness (aggression) 25, 176, $182,183,184,195-197$

alienation of labor 208-210, 212, 214, 216, 217, 227, 228, 232-235, 239-255, 257, 268, 269, 271, 275-277, 281, 282, 284, 286, 289, 293, 303, 304, 311, 315-318 approximation $100,116,119,125$, $127,131,135,136,147-149,194$, $214,256,312,323,325$

assumptions

- aggregating 103, 104, 132, 135

- counter-factual 99, 103, 114

- idealizing 99-102, 104, 114, 116, $117,127,131,133,135,161,178$, $181,209,210,239,249$

- in general 91-93, 98-103, 114, $116-118,120,121,124,126-129$, $131-136,161,178,181,194,195$, $197,209,210,239,249,325$

- quasi-idealizing 103-105, 117, $121,132,135$

- realistic 99, 114, 116, 117, 131

- simplifying 92, 93, 100, 103, 104, $113,117,120,121,129,131,132$, $135,194,195$

- stabilizing 103, 105, 117, 132, 135,325

C

Capitalism 22, 25, 57, 60, 61, 63, 65, 74, 77, 131, 198, 205, 318-320, 332

cascade effect $8,145,147,151-167$, 255, 257, 267, 269, 284, 285, 317,323 cascade process $7-9,147,151-168$, 255, 257, 267, 269, 285-287, 289, 297, 306, 307, 311, 314, 317, 323-325

categorial ontology 159-161, 164

Central Europe

- borders 5, 41, 52-54

- distinctiveness 5, 6, 41-52, 54-55, 57

- in general $5,7,8,9,41-55$

Chaos theory 35, 136-138

Christian model of man 8, 209, 219, 223, 224

civil alienation $176,177-180,182$, $183,225,226,341-343$

civilization $23,25-27,38,42,50,57$, 259, 329

civilizational dimensions 329-331 comparative method 107-114 concretization $84,93,99-102,104$, $105,114,116,120,127,135$, 147-149, 181, 205

D

Differentiation 6-9, 42, 54, 61, 63, $69,80,85,144,178,268,269$, 285-287, 297, 306, 307, 309, 311, $314,316,318,323-325$ ducal law (Ius Ducale) 260-267, 276, 277, 287, 300, 307

E

East-Central Europe 48-50, 53 economic dualism 8, 57, 166, 167 economical society, development of 208-214, 231-235

- the phase of the increasing alienation of labor 210, 232, 234 
- the phase of revolutionary disturbances 210,211,232, 233, 234

- the phase of evolution in ownership relations 211,233, 234 essential structure 7, 95-98, 103, $105,106,110,112,113,147-154$, $157-162,165,166$

\section{F}

Fatalism 23, 143

feudal society, model of 214-219

feudalism 22, 25, 54, 60, 65-67, $70,74,75,77,129,198,205,213$, $256,259,260,261,264-266,269$, 276,325

\section{G}

German Law 58, 67, 77, 79, 86, 256, 269, 271-274, 288, 300, 303, 307, 317,323

\section{H}

historical narrative $8,20,138,145$, 154, 157, 158, 159, 166

historical region 41

I

Idealization, method of $84,91,93$, $94,99,105,114-116,120,136$, $139,156,213,246,336$

idealizational law 92, 99-102, 147-149

idealizational statement 99, 136 idealizational theory of science (ITS)

- in general $7,8,94,101-103$, $109,138,144,145,148,157,159$, 323,324

- linear structure 101, 120

- range 98, 105, 106

- scope 98, 105
- specification (territorial and chronological) 9, 105, 106, 128, $131,135,325$

- star-like structure 101, 135

Idiographism 32, 162, 163, 164, 165,166

\section{M}

manorial-serf economy $6,8,49-51$, $54,69,72,73,75,76,78,84,85$, $126,257,267,268,283,287,293$, 296, 303, 305, 314, 316, 317, 321, 323,324

manorial-serf system $54,55,57,62$, $74,77,83-85,120,121,122,126$, $163,218,315,318$

measurement 103 metanarrative $20,30,31-33,38,39$

$\mathbf{N}$

Nomothetism 32, 164, 165 non-Marxian historical materialism (n-Mhm) 8, 27, 171-184, 197, 205-259, 263, 268, 323, 329-348 non-rationalistic model of man (non-Christian model of man) 8, 205, 209, 219, 222-225, 228, 340,346

O

Operationalization 102, 103, 115,136

political society, development of 175-184

- the phase of growing civil alienation 179, 182, 190, 194

- the phase of revolution of the first kind 178, 179, 182, 183, 190, 191, 194, 225, 346

- the phase of cyclical declassations $180,182,183$, 190, 194 
- the phase of enslavement 179 , $180,182,183,190,192,194$, 341,347

- the phase of cyclical revolutions of the second kind 180-181, 183,190

$\mathbf{P}$

Possibilism 142, 143

$\mathbf{R}$

revolution

- economical of the first kind 8 , 208-210, 228, 229, 231, 232, 234, 240-245, 248, 251, 252

- economical of the second kind 8 , 227-234, 240, 241, 244, 247, 248, 251,252

- in general 27, 39, 67, 72, 114, 197, 201, 229-231, 339-347

- political of the first kind 177-179, 182, 183, 191, 194, 197

- political of the second kind 178, 180-183, 194, 225

S shortage of manpower

(workforce) 9, 67, 69, 76, 85-87, 118, 248-252, 254-256, 267, 269, 274, 276, 277, 283-287, 293, 300, $303,307,312,313,317,323-325$ slavery $22,55,62,67,70,72,75,77$, 205, 213, 217, 264

social practice $140,141,330-333$, 335-338

socialism $8,22,25,43,194,197$, 198, 204, 320, 333

substantial philosophy of history

- dualistic 22

- finalistic and non-teleological 34

- finalistic-teleological 34

- in general 6, 19-22, 33, 36, 37

- non-finalistic and non-teleological 34, 35

- non-finalistic and teleological 34,35

- pluralistic 22

- universalistic 22 surplus of manpower (workforce) 9, 239, 243-245, 323,325

T

types of societies in non-Marxian historical materialism 171-175

V

Voluntarism 143

W

world-capitalist system 60,63 



\section{Geschichte - Erinnerung - Politik Studies in History, Memory and Politics}

Herausgegeben von / Edited by Anna Wolff-Powęska \& Piotr Forecki

Bd./Vol. 1 Machteld Venken: Stradding the Iron Curtain? Immigrants, Immigrant Organisations, War Memories. 2011.

Bd./Vol. 2 Anna Wolff-Powęska / Piotr Forecki: Der Holocaust in der polnischen Erinnerungskultur. 2012.

Bd./Vol. 3 Marta Grzechnik: Regional Histories and Historical Regions. The Concept of the Baltic Sea Region in Polish and Swedish Historiographies. 2012.

Bd./Vol. 4 Lutz Niethammer: Memory and History. Essays in Contemporary History. 2012.

Bd./Vol. 5 Piotr Forecki: Reconstructing Memory. The Holocaust in Polish Public Debates. 2013.

Bd./Vol. 6 Marek Słoń (ed.): Historical Atlas of Poland in the 2nd Half of the 16th Century. Voivodeships of Cracow, Sandomierz, Lublin, Sieradz, Łęczyca, Rawa, Płock and Mazovia. Volume 1-4. Translated by Agata Staszewska, Editorial Assistance Martha Brożyna. 2014.

Bd./Vol. 7 Maciej Janowski: Birth of the Intelligentsia 1750-1831. A History of the Polish Intelligentsia - Part 1. Edited by Jerzy Jedlicki. Translated by Tristan Korecki. 2014.

Bd./Vol. 8 Jerzy Jedlicki: The Vicious Circle 1832-1864. A History of the Polish Intelligentsia - Part 2. Edited by Jerzy Jedlicki. Translated by Tristan Korecki. 2014.

Bd./Vol. 9 Magdalena Micińska: At the Crossroads 1865-1918. A History of the Polish Intelligentsia - Part 3. Edited by Jerzy Jedlicki. Translated by Tristan Korecki. 2014.

Bd./Vol. 10 Anna Wolff-Powęska: Memory as Burden and Liberation. Germans and their Nazi Past (1945-2010). Translated by Marta Skowrońska. 2015.

Bd./Vol. 11 Thomasz Szarota: On the Threshold of the Holocaust. Anti-Jewish Riots and Pogroms in Occupied Europe. Warsaw - Paris - The Hague - Amsterdam Antwerp - Kaunas. Translated by Tristan Korecki. 2015.

Bd./Vol. 12 Anna Wolff-Powęska / Piotr Forecki (eds.): World War II and Two Occupations. Dilemmas of Polish Memory. Translated by Marta Skowrońska and Blanka Zahorjanova. 2016.

Bd./Vol. 13 Elżbieta Katarzyna Dzikowska / Agata Handley / Piotr Zawilski (eds.): The Great War. Insights and Perspectives. 2016.

Bd./Vol. 14 Jerzy Jedlicki: A Degenerate World. Translated by Tristan Korecki. Edited by Elena Rozbicka. 2016.

Bd./Vol. 15 Miroslaw Matyja: Zwischen Krieg und Hoffnung. Internierung der 2. polnischen Infanterieschützen-Division in der Schweiz 1940-45. 2016.

Bd./Vol. 16 Adam Leszczyński: Leap into Modernity - Political Economy of Growth on the Periphery, 1943-1980. 2017.

Bd./Vol. 17 Antoine Marès / Wojciech Prażuch / Inga Kawka (eds.) : Les exilés polonais en France et la réorganisation pacifique de l'Europe (1940-1989). 2017. 
Bd./Vol. 18 Dominika Gortych / Guido Hinterkeuser / Łukasz Skoczylas: Erinnerungsimplantate - Der (Wieder-)Aufbau der Schlösser in Posen und Berlin im interdisziplinären Vergleich. Unter Mitwirkung von Karsten Holste. 2017.

Bd./Vol. 19 Elżbieta Katarzyna Dzikowska / Agata G. Handley / Piotr Zawilski (eds.): Beyond the Trenches - The Social and Cultural Impact of the Great War. 2017. Second Edition 2019.

Bd./Vol. 20 Marcin Zaremba: Communism - Legitimacy - Nationalism. Nationalist Legitimization of the Communist Regime in Poland. 2019.

Bd./Vol. 21 Klaus Bachmann: Genocidal Empires. German Colonialism in Africa and the Third Reich. Edited by Barbara Kurowska. 2018.

Bd./Vol. 22 Krzysztof Trybuś / Michael Düring / Maciej Junkiert (Hrsg.): Polen und Deutsche in Europa. Polacy i Niemcy w Europie. Beiträge zur internationalen Konferenz, 16. und 17. November 2015, Poznań. Tom podsumowujący międzynarodową konferencję, 16 i 17 listopada 2015, Poznań. 2018.

Bd./Vol. 23 Monika Jaglarz / Katarzyna Jaśtal (Hrsg.): Bestände der ehemaligen Preußischen Staatsbibliothek zu Berlin in der Jagiellonen-Bibliothek. Forschungsstand und -perspektiven. 2018.

Bd./Vol. 24 Zuzanna Bogumił / Małgorzata Głowacka-Grajper: Milieux de mémoire in Late Modernity. Local Community, Religion and Historical Politics. 2019.

Bd./Vol. 25 Bruno Kamiński: Fear Management. Foreign Threats in the Post-War Polish Propaganda. The Influence and the Reception of the Communist Media (1944-1956). 2019.

Bd./Vol. 26 Anna Wylegała: Displaced Memories. Remembering and Forgetting in PostWar Poland and Ukraine. 2019.

Bd./Vol. 27 Iwona Zamkowska: Religious Liberty in the Educational System of the United States. From the 1980s to the Present. 2019.

Bd./Vol. 28 Sylwia Bykowska: The Rehabilitation and Ethnic Vetting of the Polish Population in the Voivodship of Gdańsk after World War II. 2019.

Bd./Vol. 29 Aleksander Łupienko: Order in the Streets. The Political History of Warsaw's Public Space in the First Half of the 19th Century. 2019.

Bd./Vol. 30 Jozef Vladár / Egon Wiedermann: The World behind the World. Intercultural Processes in the Prehistory of European Civilization. 2020.

Bd./Vol. 31 Krzysztof Brzechczyn: The Historical Distinctiveness of Central Europe. A Study in the Philosophy of History. 2020.

www.peterlang.com 